Prepared in cooperation with the Pennsylvania Department of Environmental Protection

\title{
Occurrence of Pharmaceuticals, Hormones, and Organic Wastewater Compounds in Pennsylvania Waters, 2006-09
}

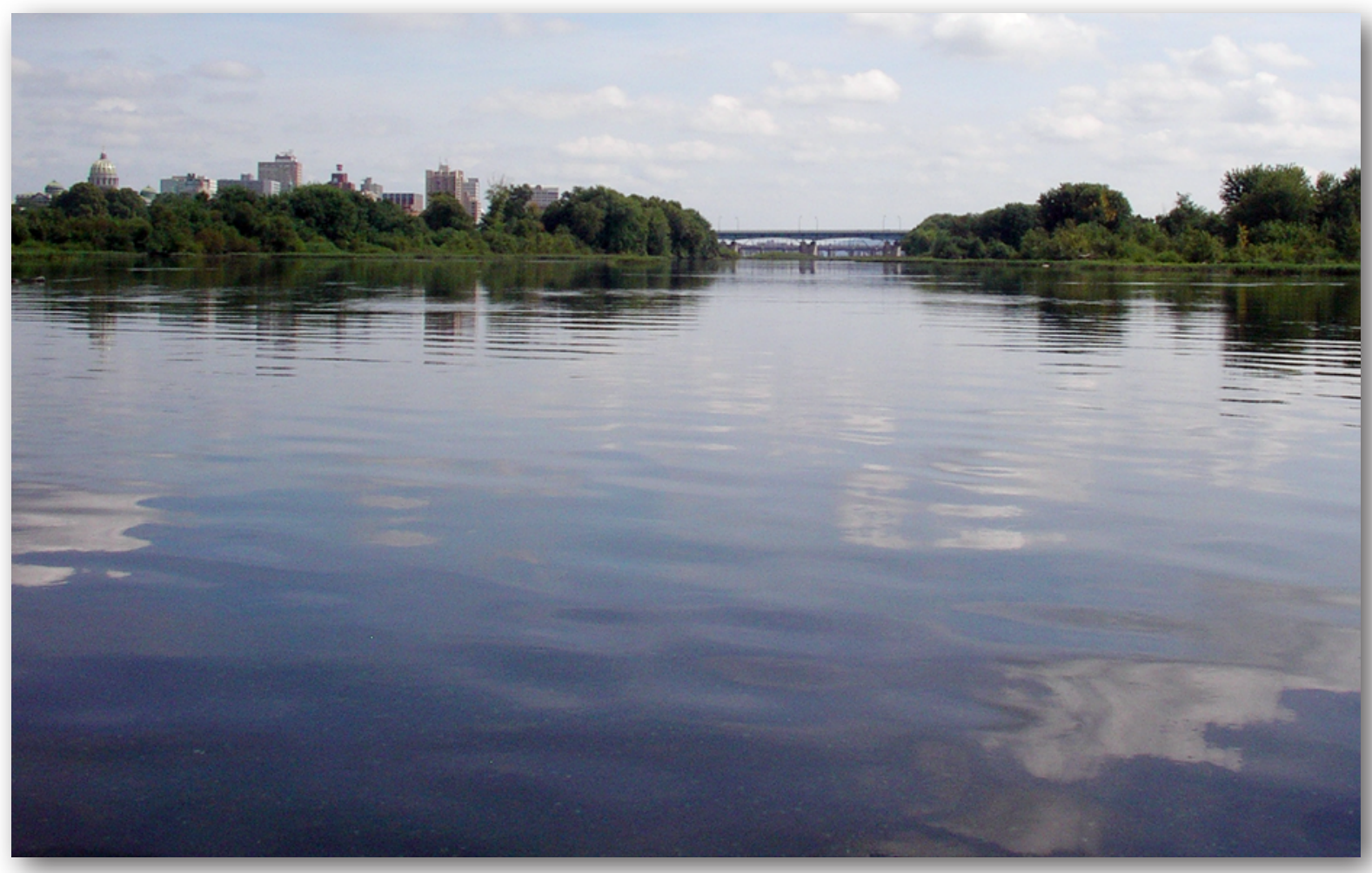

Scientific Investigations Report 2012-5106 
Cover. Susquehanna River at Harrisburg, Pa. Photo by J. Kent Crawford, U.S. Geological Survey. 


\section{Occurrence of Pharmaceuticals, Hormones, and Organic Wastewater Compounds in Pennsylvania Waters, 2006-09}

By Andrew G. Reif, J. Kent Crawford, Connie A. Loper, Arianne Proctor, Rhonda Manning, and Robert Titler

Prepared in cooperation with the

Pennsylvania Department of Environmental Protection

Scientific Investigations Report 2012-5106 


\title{
U.S. Department of the Interior \\ KEN SALAZAR, Secretary \\ U.S. Geological Survey \\ Marcia K. McNutt, Director
}

\author{
U.S. Geological Survey, Reston, Virginia: 2012
}

For more information on the USGS - the Federal source for science about the Earth, its natural and living resources, natural hazards, and the environment, visit http://www.usgs.gov or call 1-888-ASK-USGS.

For an overview of USGS information products, including maps, imagery, and publications, visit http://www.usgs.gov/pubprod

To order this and other USGS information products, visit http://store.usgs.gov

Any use of trade, product, or firm names is for descriptive purposes only and does not imply endorsement by the U.S. Government.

Although this report is in the public domain, permission must be secured from the individual copyright owners to reproduce any copyrighted materials contained within this report.

Suggested citation:

Reif, A.G., Crawford, J.K., Loper, C.A., Proctor, Arianne, Manning, Rhonda, and Titler, Robert, 2012, Occurrence of pharmaceuticals, hormones, and organic wastewater compounds in Pennsylvania waters, 2006-09: U.S. Geological Survey Scientific Investigations Report 2012-5106, 99 p. 


\section{Acknowledgements}

Funding support from the Pennsylvania Department of Environmental Protection and the U.S. Environmental Protection Agency is gratefully acknowledged. USGS researchers Dana Kolpin, William Foreman, Edward Furlong, Michael Meyer, Steven Zaugg, Keith Loftin, and James Gray conducted laboratory analyses and provided valuable advice throughout the study; without them the study would not have been possible. John Clune, Justin Knudson, Leif Olson, Tom Noonan, Heather Eggleston, and Emily Eggler, played an important role in sample collection. Linda Zarr contributed her expertise to the data analysis. Scott Hoffman provided valuable graphics support. Kim Otto (retired) provided editorial support. USGS reviewer Kevin Breen provided a particularly insightful review of an early draft of the manuscript. Other USGS reviewers, Lisa Senior, Pat Philips, and Doug Chambers offered valuable suggestions

for improving the manuscript. The interest and support of Pat Bowling of the PADEP is greatly appreciated. The authors also wish to extend thanks to the landowners and the wastewatertreatment-plant operators who graciously allowed access to the wells and streams. To all who assisted in any way, the authors convey sincere thanks. 


\section{Contents}

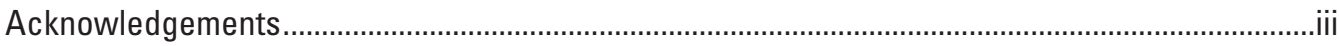

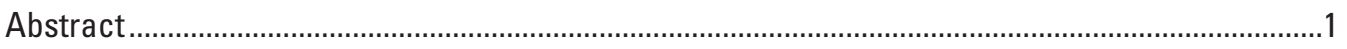

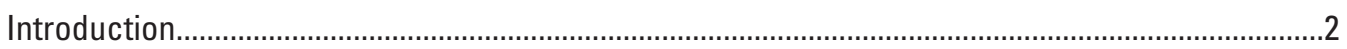

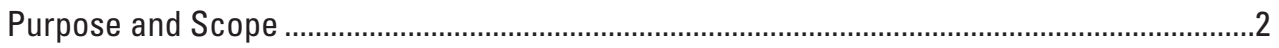

Categories of Contaminants of Emerging Concern .................................................................

Potential Sources of Contaminants of Emerging Concern ....................................................11

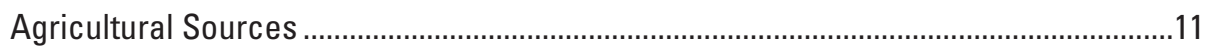

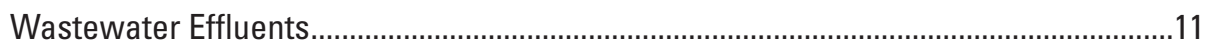

Other Potential Sources of Contaminants of Emerging Concern ....................................11

Pharmaceutical Manufacturing Facilities ..............................................................11

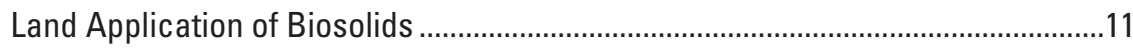

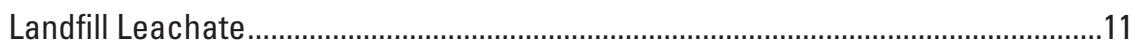

Combined Sewer Overflows ..........................................................................12

On-Site Wastewater Systems............................................................................12

Previous and Current Investigations ..............................................................................12

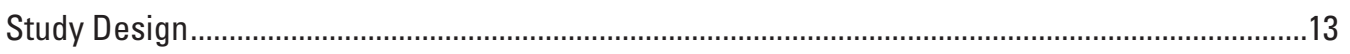

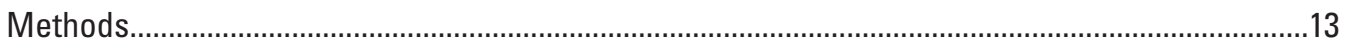

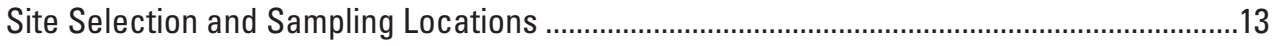

Wells in Agricultural Areas Used to Supply Livestock ................................................13

Streams Draining Areas with Animal-Feeding Operations.............................................19

Streams Receiving Municipal Wastewater Effluents.......................................................19

Stream Sites near Drinking-Water Intakes ..................................................................19

Stream Sites Used to Evaluate Fish Health ..............................................................20

Streamflow Measurement and Water-Quality Characteristics ...............................................20

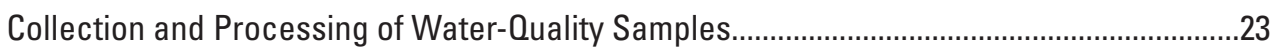

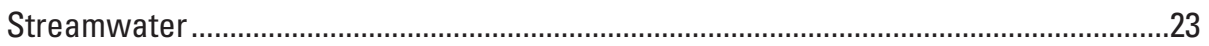

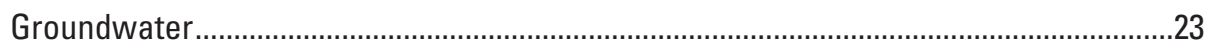

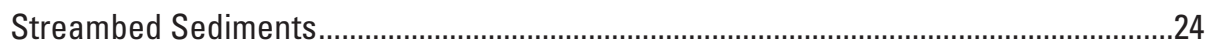

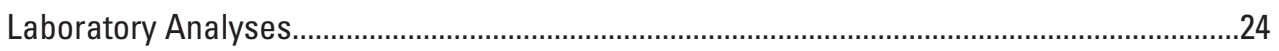

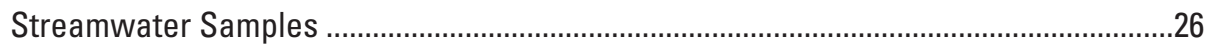

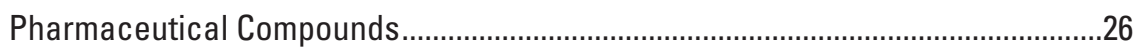

Antibiotics and Ibuprofen ...............................................................................26

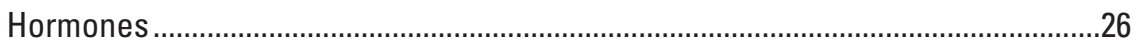

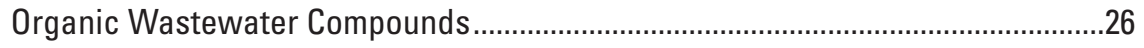

Streambed-Sediment Samples.................................................................................26

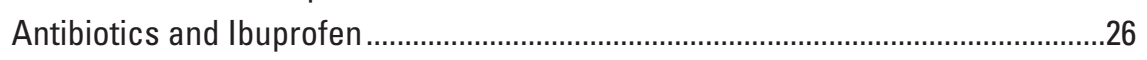

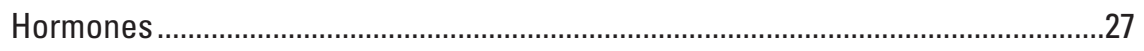

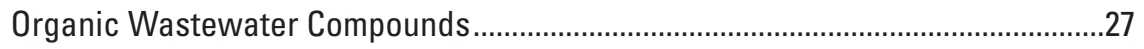

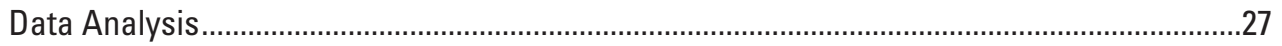

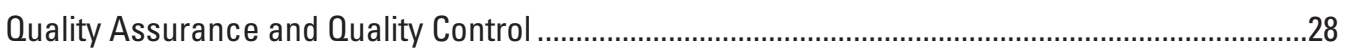

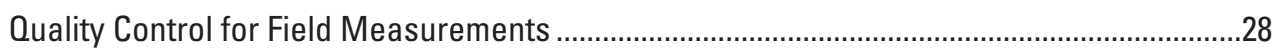

Quality Control for Streamwater and Streambed-Sediment Samples ....................................28 


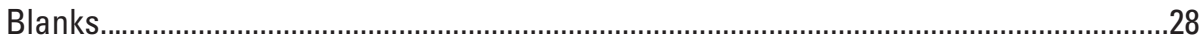

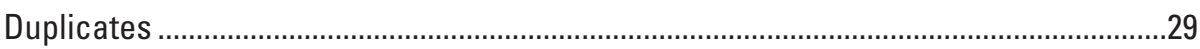

Laboratory-Matrix Spikes ......................................................................................................29

Pharmaceuticals, Hormones, and Organic Wastewater Compounds in Pennsylvania Waters.....31

Compounds in Groundwater Used to Supply Livestock ...........................................................31

Compounds in Streamwaters Upstream and Downstream from Animal-Feeding

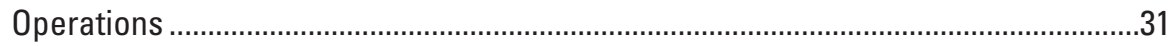

Compounds in Streamwater and Streambed Sediments Upstream and Downstream from Wastewater Discharges ..................................................................................

2006 Sampling Upstream and Downstream from Wastewater-Effluent-Discharge

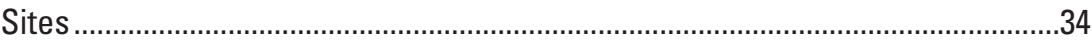

2007 to 2009 Sampling Downstream from Wastewater-Effluent Discharges .................40

Compounds in Streamwaters near Drinking-Water Intakes ......................................................47

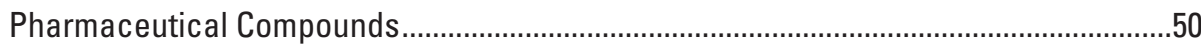

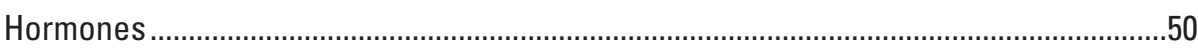

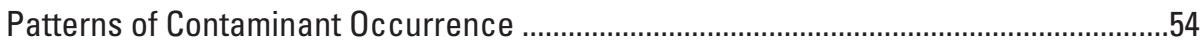

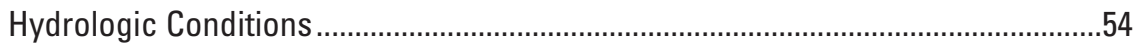

Number of Permitted Discharges ...........................................................................54

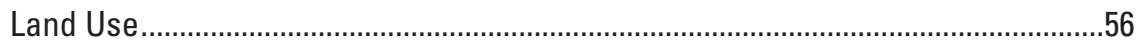

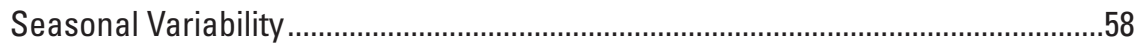

Compounds in Streamwaters and Streambed Sediment at Fish-Health Sites .......................60

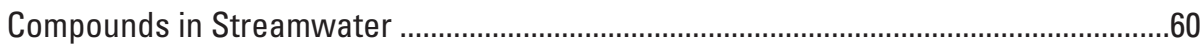

Compounds in Streambed Sediment ...........................................................................60

Implications of Contaminants of Emerging Concern in Pennsylvania Waters .................................65

Implications for Ecosystem Health .......................................................................................65

Implications for Contaminants in Source Waters for Public Drinking-Water Supplies ..........66

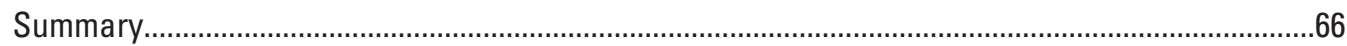

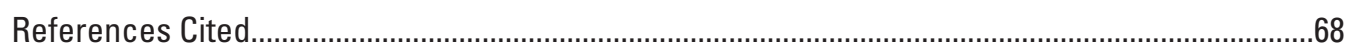

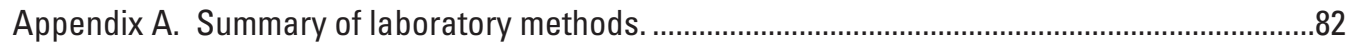

Appendix B. Summary of duplicate sample results .......................................................................83

Appendix C. Reagent-spiked and laboratory-spiked sample results ..........................................87 


\section{Figures}

1. Map showing locations of wells used to supply livestock, stream-sampling sites near animal-feeding operations, and stream-sampling sites near municipal wastewater-effluent-discharge sites, south-central Pennsylvania

2. Map showing locations of stream-sampling sites located near drinking-water intakes and sampling sites for evaluation of fish health in Pennsylvania.. 16

3. Photograph showing U.S. Geological Survey hydrologist collecting a water sample for analysis of contaminants of emerging concern using a DH-81 sampler fitted with Teflon adapter, Teflon nozzle, and Teflon 1-L bottle

4. Photograph showing Teflon cylinder and Teflon wafer used to collect streambed-sediment samples

5. Photograph showing U.S. Geological Survey and Pennsylvania Department of Environmental Protection scientists processing a streambed-sediment sample in the field

6. Graph showing pharmaceutical compounds detected in 24 streamwater samples collected from paired stream sites located upstream and downstream from five animal-feeding operations in Pennsylvania, 2006.

7. Graph showing number of detections of pharmaceutical compounds, excluding antibiotics, in 20 streamwater samples collected from paired stream sites located upstream and downstream from five municipal wastewater-effluentdischarge-sites in Pennsylvania, 2006

8. Boxplot showing number of detections of antibiotic compounds at concentrations greater than the reporting level in 20 streamwater samples collected from paired stream sites located upstream and downstream from five municipal wastewater-effluent-discharge sites in Pennsylvania, 2006.

9. Graph showing carbamazepine concentrations in streamwater samples collected from paired stream sites located upstream and downstream from five municipal wastewater-effluent-discharge sites in Pennsylvania, 2006.

10. Boxplot showing sulfamethoxazole and ofloxacin concentrations detected in samples collected from Lititz Creek near Lititz, Pennsylvania, the upstream site, T12, 01576420 and Lititz Creek at Rothsville, Pennsylvania, the downstream site, $\mathrm{T} 13,01576422$, in 2006

11. Graph showing number of contaminants of emerging concern detected at concentrations greater than the reporting level in streamwater samples collected from sites downstream from municipal wastewater-effluent-discharge sites in Pennsylvania, 2007-09.

12. Graph showing number of contaminants of emerging concern detected at concentrations greater than the reporting level in streambed-sediment samples collected from the Clark Creek reference site and eight stream sites located downstream from municipal wastewater-effluent-discharge sites in Pennsylvania, 2007-09.

13. Graph showing detection frequency of selected contaminants of emerging concern detected at concentrations greater than the reporting level in streamwater and streambed-sediment samples collected from eight sites located downstream from municipal wastewater-effluent-discharge sites in Pennsylvania, 2007-09

14. Map showing locations of 27 streamwater-sampling sites near drinking-water intakes with the number of total detections at concentrations greater than the reporting level, by compound class, in Pennsylvania, 2007-09. 
15. Graph showing number of detections of pharmaceutical compounds in streamwater samples collected from 27 stream sites located near drinking-water intakes in Pennsylvania, 2007-09.

16. Graph showing number of contaminants of emerging concern detected at concentrations greater than the reporting level in streamwater samples collected from 27 stream sites near drinking-water intakes in Pennsylvania, 2007-09.

17. Graph showing number of detections of hormone and animal sterol compounds in 270 streamwater samples collected from 27 stream sites near drinking-water intakes in Pennsylvania, 2007-09.

18. Graph showing concentration of sulfamethoxazole in streamwater samples collected from the Schuylkill River at Philadelphia, Pennsylvania, in relation to streamflow, 2007-09

19. Graph showing detection frequency of commonly detected contaminants of emerging concern in each of four flow categories for streamwater samples taken from 27 stream sites located near drinking-water intakes in Pennsylvania, 2007-09 ....55

20. Graph showing number of detections of contaminants of emerging concern at concentrations greater than the reporting level by permitted discharges categories-low, mid, and high-for 27 stream sites located near drinking-water intakes in Pennsylvania, 2007-09.

21. Graph showing detection frequency of selected contaminants of emerging concern by permitted discharge category—low, mid, and high—for 27 stream sites located near drinking-water intakes in Pennsylvania, 2007-09.

22. Graph showing number of detections of contaminants of emerging concern at concentrations greater than the reporting level in samples collected from 27 stream sites near drinking-water intakes by percentage of forested land use in Pennsylvania, 2007-09.

23. Graph showing number of detections of contaminants of emerging concern at concentrations greater than the reporting level in streamwater samples collected from 27 stream sites near drinking-water intakes in Pennsylvania, 2007-09

24. Graph showing detection frequency of contaminants of emerging concern, by season, in 297 streamwater samples collected from 27 stream sites near drinking-water intakes in Pennsylvania, 2007-09.

25. Graph showing detection frequency of sulfamethoxazole and acetaminophen, by season, in 297 streamwater samples collected from 27 stream sites near drinking-water intakes in Pennsylvania, 2007-09.

26. Map showing location of fish-health sites sampled with the number of total detections greater than the reporting level, by compound class, in Pennsylvania, 2007 or 2008

27. Graph showing number of contaminants of emerging concern detected at concentrations greater than the reporting level in streamwater samples collected at 16 fish-health sites in Pennsylvania, 2007 or 2008

28. Graph showing number of contaminants of emerging concern detected at concentrations greater than the reporting level in streambed-sediment samples from 16 fish-health sites sampled in Pennsylvania, 2007 or 2008 


\section{Tables}

1. Pharmaceutical compounds analyzed in streamwater and streambed-sediment samples, medicinal uses, and reporting levels..

2. Hormones and animal sterols analyzed in streamwater and streambed-sediment samples, medicinal uses, and reporting levels.

3. Organic wastewater compounds analyzed in streamwater and streambed-sediment samples, uses or sources, and reporting levels.

4. Objective addressed, study component, duration of sampling, number of locations sampled, sample medium, compounds analyzed, and number of samples collected for reconnaissance sampling of waters in Pennsylvania, 2006-09...

5. Description of well sites used to supply livestock, stream sites receiving runoff from animal-feeding operations, and stream sites near municipal wastewatereffluent-discharge sites, in south-central Pennsylvania, 2006-09.

6. Characteristics of wastewater-treatment-plants discharging to study streams ............20

7. Description of sampling sites near selected drinking-water intakes in Pennsylvania...21

8. Description of sampling sites used for evaluations of fish health in Pennsylvania ........22

9. Description of field measurement with reporting units and instrument reporting accuracies used in this study

10. Compounds detected in equipment and field-blank samples collected from 2006 to 2009.

11. Statistical summary of relative percent differences for contaminants of emerging concern in duplicate samples of streamwater and streambed sediment collected in Pennsylvania, 2007-09.

12. Statistical summary of recoveries of laboratory-matrix spike samples for selected analytical methods used in this study

13. Pharmaceutical compounds detected in quarterly samples collected from 6 wells in agricultural areas and 12 stream sites located upstream and downstream from animal-feeding operations in Pennsylvania.

14. Pharmaceutical compounds detected in streamwater samples collected from paired stream sites located upstream and downstream from five municipal wastewater-effluent-discharge sites in Pennsylvania, 2006.

15. Description of sampling sites downstream from wastewater-effluent-discharge sites, number of compounds detected, total number of detections, average flow difference between upstream and downstream sampling sites, and drainage area for streamwater samples collected in Pennsylvania, 2006.

16. Pharmaceutical compounds detected in streamwater and streambed-sediment samples collected from Clark Creek and eight stream sites downstream from wastewater-effluent-discharge sites in Pennsylvania, 2007-09

17. Hormone and animal sterol compounds detected in streamwater and streambed-sediment samples collected annually from Clark Creek and eight stream sites located downstream from municipal wastewater-effluent-discharge sites in Pennsylvania, 2007-09

18. Organic wastewater compounds detected in annual streamwater or streambedsediment samples collected at Clark Creek and eight stream sites located downstream from municipal wastewater-effluent-discharge sites in Pennsylvania, 2007-09.

19. Pharmaceutical and hormone and animal sterol compounds detected in streamwater samples collected from 27 stream sites located near drinking-water intakes in Pennsylvania, 2007-09. 
20. Land-use statistics for 27 stream sites near drinking-water intakes in Pennsylvania, 2007-09.

21. Contaminant of emerging concern compounds detected in streamwater and streambed-sediment samples collected from 16 fish-health sites in Pennsylvania, 2007-09.

22. Detection frequencies of selected compounds in samples collected from sites downstream from wastewater-effluent-discharge sites, 2007-09; sites near drinkingwater intakes, 2007-09; and fish-health sites, 2007 and 2008, in Pennsylvania

\section{Conversion Factors and Datum}

\begin{tabular}{|c|c|c|}
\hline Multiply & By & To obtain \\
\hline \multicolumn{3}{|c|}{ Length } \\
\hline centimeter $(\mathrm{cm})$ & 0.3937 & inch (in.) \\
\hline meter $(\mathrm{m})$ & 3.281 & foot $(\mathrm{ft})$ \\
\hline kilometer (km) & 0.6214 & mile (mi) \\
\hline \multicolumn{3}{|c|}{ Area } \\
\hline square kilometer $\left(\mathrm{km}^{2}\right)$ & 0.3861 & square mile $\left(\mathrm{mi}^{2}\right)$ \\
\hline \multicolumn{3}{|c|}{ Volume } \\
\hline liter (L) & 33.82 & ounce, fluid (fl. oz) \\
\hline liter $(\mathrm{L})$ & 2.113 & pint $(p t)$ \\
\hline liter $(\mathrm{L})$ & 1.057 & quart (qt) \\
\hline liter $(\mathrm{L})$ & 0.2642 & gallon (gal) \\
\hline \multicolumn{3}{|c|}{ Flow rate } \\
\hline meter per second $(\mathrm{m} / \mathrm{s})$ & 3.281 & foot per second (ft/s) \\
\hline cubic meter per second $\left(\mathrm{m}^{3} / \mathrm{s}\right)$ & 35.31 & cubic foot per second $\left(\mathrm{ft}^{3} / \mathrm{s}\right)$ \\
\hline cubic meter per second $\left(\mathrm{m}^{3} / \mathrm{s}\right)$ & 22.83 & million gallons per day $(\mathrm{Mgal} / \mathrm{d})$ \\
\hline \multicolumn{3}{|c|}{ Mass } \\
\hline gram $(\mathrm{g})$ & 0.03527 & ounce, avoirdupois (oz) \\
\hline \multicolumn{3}{|c|}{ Pressure } \\
\hline megapascal (MPa) & 145.037 & pound per square inch $\left(\mathrm{lb} / \mathrm{in}^{2}\right)$ \\
\hline
\end{tabular}

Temperature in degrees Celsius $\left({ }^{\circ} \mathrm{C}\right)$ may be converted to degrees Fahrenheit $\left({ }^{\circ} \mathrm{F}\right)$ as follows:

${ }^{\circ} \mathrm{F}=\left(1.8 x^{\circ} \mathrm{C}\right)+32$

Temperature in degrees Fahrenheit $\left({ }^{\circ} \mathrm{F}\right)$ may be converted to degrees Celsius $\left({ }^{\circ} \mathrm{C}\right)$ as follows:

${ }^{\circ} \mathrm{C}=\left({ }^{\circ} \mathrm{F}-32\right) / 1.8$

Horizontal coordinate information is referenced to the North American Datum of 1983 (NAD 83)

Specific conductance is given in microsiemens per centimeter at 25 degrees Celsius $(\mu \mathrm{S} / \mathrm{cm}$ at $\left.25^{\circ} \mathrm{C}\right)$.

Concentrations of chemical constituents in water are given in nanograms per liter (ng/L).

Concentrations of chemical constituents in stream-bed sediment are given in micrograms per kilogram $(\mu \mathrm{g} / \mathrm{kg})$. 
Abbreviations and Acronyms

\begin{tabular}{|c|c|}
\hline AFO & Animal feeding operation \\
\hline AHTN & 6-Acetyl-1,1,2,4,4,7-hexamethyltetraline \\
\hline ASE & Accelerated solvent extraction \\
\hline BHA & 3-tert-Butyl-4-hydroxyanisole \\
\hline CAS & American Chemical Society's chemical abstract service \\
\hline CSO & Combined sewer overflow \\
\hline $\mathrm{DCM} / \mathrm{MeOH}$ & five percent methanol in dichloromethane \\
\hline DEET & N,N-diethyl-m-toluamide \\
\hline ESI & Electrospray ionization \\
\hline GAC & Granular activated carbon \\
\hline GC/MS & Gas chromatography/mass spectrometry \\
\hline GFF & Glass fiber filter \\
\hline HHCB & Hexahydrohexamethyl-cyclopentabenzopyran \\
\hline HPLC & High-performance liquid chromatography \\
\hline HPLC/MS & High-performance liquid chromatography/mass spectrometry \\
\hline IDS & Isotope dilution standard \\
\hline LC/MS/MS & Liquid chromatography/tandem mass spectrometry \\
\hline LMS & Laboratory matrix spike \\
\hline LRB & Laboratory reagent blank \\
\hline LRL & Laboratory reporting limit \\
\hline MRL & Minimum reporting level \\
\hline MRM & Multiple reaction monitoring \\
\hline NF/RO & Nanofiltration/reverse osmosis \\
\hline NP & total, para-Nonylphenol \\
\hline NWIS & National Water Information System \\
\hline OPE01 & Octylphenol, monoethoxy \\
\hline OPEO2 & Octylphenol, diethoxy \\
\hline PADEP & Pennsylvania Department of Environmental Protection \\
\hline PAH & Polycyclic aromatic hydrocarbon \\
\hline PA-WSC & Pennsylvania Water Science Center \\
\hline PDBE 47 & 2,2',4,4'-Tetrabromo diphenylether \\
\hline MDL & Method detection limit \\
\hline MSTFA & $N$-methyl- $N$-(trimethylsilyl)- trifluoroacetamide \\
\hline NPEO2 & nonylphenol, diethoxy (total) \\
\hline NWQL & National Water Quality Laboratory \\
\hline ORGL & Organic Geochemistry Research Laboratory \\
\hline OWC & Organic Wastewater Compound \\
\hline RNA & Ribonucleic acid \\
\hline RPD & Relative percent difference \\
\hline SPE & Solid-phase extraction \\
\hline USGS & U.S. Geological Survey \\
\hline WON & Water Quality Network \\
\hline
\end{tabular}




\title{
Occurrence of Pharmaceuticals, Hormones, and Organic Wastewater Compounds in Pennsylvania Waters, 2006-09
}

\author{
By Andrew G. Reif, J. Kent Crawford, Connie A. Loper, Arianne Proctor, Rhonda Manning, and Robert Titler
}

\section{Abstract}

Concern over the presence of contaminants of emerging concern, such as pharmaceutical compounds, hormones, and organic wastewater compounds (OWCs), in waters of the United States and elsewhere is growing. Laboratory techniques developed within the last decade or new techniques currently under development within the U.S. Geological Survey now allow these compounds to be measured at concentrations in nanograms per liter. These new laboratory techniques were used in a reconnaissance study conducted by the U.S. Geological Survey, in cooperation with the Pennsylvania Department of Environmental Protection, to determine the occurrence of contaminants of emerging concern in streams, streambed sediment, and groundwater of Pennsylvania. Compounds analyzed for in the study are pharmaceuticals (human and veterinary drugs), hormones (natural and synthetic), and OWCs (detergents, fragrances, pesticides, industrial compounds, disinfectants, polycyclic aromatic hydrocarbons, fire retardants and plasticizers). Reconnaissance sampling was conducted from 2006 to 2009 to identify contaminants of emerging concern in (1) groundwater from wells used to supply livestock, (2) streamwater upstream and downstream from animal feeding operations, (3) streamwater upstream from and streamwater and streambed sediment downstream from municipal wastewater effluent discharges, (4) streamwater from sites within 5 miles of drinking-water intakes, and (5) streamwater and streambed sediment where fish health assessments were conducted.

Of the 44 pharmaceutical compounds analyzed in groundwater samples collected in 2006 from six wells used to supply livestock, only cotinine (a nicotine metabolite) and the antibiotics tylosin and sulfamethoxazole were detected. The maximum concentration of any contaminant of emerging concern was 24 nanograms per liter $(\mathrm{ng} / \mathrm{L})$ for cotinine, and was detected in a groundwater sample from a Lebanon County, Pa., well.

Seven pharmaceutical compounds including acetaminophen, caffeine, carbamazepine, and the four antibiotics tylosin, sulfadimethoxine, sulfamethoxazole, and oxytetracycline were detected in streamwater samples collected in 2006 from six paired stream sampling sites located upstream and downstream from animal-feeding operations. The highest reported concentration of these seven compounds was for the antibiotic sulfamethoxazole $(157 \mathrm{ng} / \mathrm{L})$, in a sample from the downstream site on Snitz Creek in Lancaster County, Pa.

Twenty-one pharmaceutical compounds were detected in streamwater samples collected in 2006 from five paired stream sampling sites located upstream or downstream from a municipal wastewater-effluent-discharge site. The most commonly detected compounds and maximum concentrations were the anticonvulsant carbamazepine, $276 \mathrm{ng} / \mathrm{L}$; the antihistamine diphenhydramine, $135 \mathrm{ng} / \mathrm{L}$; and the antibiotics ofloxacin, $329 \mathrm{ng} / \mathrm{L}$; sulfamethoxazole, 1,340 ng/L; and trimethoprim, $256 \mathrm{ng} / \mathrm{L}$.

A total of 51 different contaminants of emerging concern were detected in streamwater samples collected from 2007 through 2009 at 13 stream sampling sites located downstream from a wastewater-effluent-discharge site. The concentrations and numbers of compounds detected were higher in stream sites downstream from a wastewater-effluent-discharge site than in stream sites upstream from a wastewater-effluentdischarge site. This finding indicates that wastewater-effluent discharges are a source of contaminants of emerging concern; these contaminants were present more frequently in the streambed-sediment samples than in streamwater samples. Antibiotic compounds were often present in both the streamwater and streambed-sediment samples, but many OWCs were present exclusively in the streambed-sediment samples. Compounds with endocrine disrupting potential including detergent metabolites, pesticides, and flame retardants, were present in the streamwater and streambed-sediment samples. Killinger Creek, a stream where wastewater-effluent discharges contribute a large percentage of the total flow, stands out as a stream with particularly high numbers of compounds detected and detected at the highest concentrations measured in the reconnaissance sampling.

Nineteen contaminants of emerging concern were detected in streamwater samples collected quarterly from 2007 through 2009 at 27 stream sites within 5 miles of a drinking-water intake. The number of contaminants and the concentrations detected at the stream sites within 5 miles 
of drinking-water intakes were generally very low (concentrations less than $50 \mathrm{ng} / \mathrm{L}$ ), much lower than those at sites downstream from a wastewater-effluent discharge. The most commonly detected compounds and maximum concentrations were caffeine, $517 \mathrm{ng} / \mathrm{L}$; carbamazepine, $95 \mathrm{ng} / \mathrm{L}$; sulfamethoxazole, $146 \mathrm{ng} / \mathrm{L}$; and estrone, $3.15 \mathrm{ng} / \mathrm{L}$. The concentrations and frequencies of detection of some of the contaminants of emerging concern appear to vary by season, which could be explained by compound use, flow regime, or differences in degradation rates. Concentrations of some contaminants were associated with lower flows as a result of decreased in-stream dilution of wastewater effluents or other contamination sources.

Twenty-two contaminants of emerging concern were detected once each in streamwater samples collected in 2007 and 2008 from 16 fish-health stream sites located statewide. The highest concentrations were for the OWCs, including flame retardants tri(2-butoxyethyl)phosphate (604 ng/L) and tri(2-chloroethyl)phosphate $(272 \mathrm{ng} / \mathrm{L})$ and the fragrance isoquinoline $(330 \mathrm{ng} / \mathrm{L})$. Far fewer numbers of contaminants of emerging concern were detected at the fish-health sites than at the wastewater-effluent-discharge sites. Most of the fish-health sites were not located directly downstream from a wastewatereffluent discharge, but there were multiple wastewater-effluent discharges in the drainage basins upstream from the sampling sites. No distinct pattern of contaminant occurrence could be discerned for the fish-health stream sites.

\section{Introduction}

In recent years, certain groups of compounds referred to as "contaminants of emerging concern" have gained widespread attention in the scientific literature and in the public press. The attention has resulted, in part, because technological advancements have "made it possible to detect and quantify nearly any compound at diminishingly minute concentrations in water" (Snyder and others, 2009). Researchers have documented the occurrence of these contaminants in streams (Kolpin and others, 2002) and groundwater (Barnes and others, 2008), but the extent of their distribution and the consequences of their presence are largely unknown (Daughton and Ternes 1999; Jorgensen and Halling-Sorensen, 2000).

Virtually all chemical compounds used by humans have pathways to the environment. The combination of compound use and compound physical and chemical properties influences the likelihood of its detection in the environment. Persistent compounds remain in the environment for long periods of time in their original form and are more likely to be found in the environment than nonpersistent compounds that break down rapidly once they are in the environment. Compounds that partition strongly to solids are not likely to be detected in water but may accumulate in sediments. On the other hand, hydrophilic (water-loving) compounds are more likely to be transported to aquifers or streams as solutes and can be detected at levels in proportion to use and excretion. Compounds that degrade readily by chemical or biological processes may leave behind metabolite breakdown products in water or sediments.

\section{Purpose and Scope}

The purpose of this report is to summarize the occurrence and concentrations of three groups of contaminants of emerging concern in selected waters and streambed sediments in Pennsylvania, which are based on reconnaissance data collected from 2006 through 2009. The three groups of contaminants are pharmaceutical compounds, hormones, and organic wastewater compounds (OWCs). Analytical results are presented for 44 pharmaceutical compounds, 17 hormones and 2 animal sterols, and 56 OWCs analyzed in water, and for 27 antibiotics, 17 hormones and 2 animal sterols, and 51 OWCs analyzed in streambed-sediment samples. This report summarizes and presents discussions of the findings from the reconnaissance sampling conducted from 2006 to 2009. Concentration ranges for compounds are listed in tables, and detection frequencies (detections per number of samples) are shown in figures.

\section{Categories of Contaminants of Emerging Concern}

Contaminants of emerging concern include manufactured and natural organic compounds that may be categorized as pharmaceutical compounds (human and veterinary drugs, including antibiotics), as natural and synthetic hormones, and as OWCs (substances associated with effluents from municipal wastewater-treatment plants). Because of the numerous sources and number of compounds, it is not practical to analyze for every compound that can potentially make its way into the environment. However, subsets of pharmaceutical, hormone, and organic wastewater compounds can be quantified using newly developed laboratory techniques.

Pharmaceuticals are primarily organic compounds formulated to serve therapeutic purposes in humans and animals. Pharmaceuticals enter the environment as a result of the improper disposal of drugs and the discharge of excreted waste containing metabolized and un-metabolized pharmaceuticals into sanitary sewers. Khan and Ongerth (2002) point to the increasing frequency of detection of pharmaceutical residues in sewage sludge. Some of these compounds are considered endocrinologically active compounds termed "endocrine disruptors" and may disrupt the endocrine system of fish and other wildlife (Lintelmann and others, 2003). Increasing sales of prescription drugs substantially increase the likelihood that the drugs will be detected in streamwater and groundwater, and new drugs are continually being approved. The compounds included in the pharmaceutical analysis and their reporting levels are listed in table 1. Prescription and non-prescription medications, along with metabolite 
breakdown products (para-xanthine and cotinine) and caffeine, are included in the pharmaceutical analysis. Although para-xanthine, cotinine, and caffeine are not strictly pharmaceuticals (table 1), they are included in the discussions under the general term pharmaceutical compounds because they are associated with human use.

Antibiotics represent a subset of the pharmaceutical compounds that are used in humans and animals to kill bacteria or prevent bacterial infections and to promote growth in farm animals. Antibiotics are widely used to treat common respiratory infections, urinary tract infections, sexually transmitted diseases, burns, and skin rashes. They are also used for more serious bacterial health issues like meningitis, cholera, Rickettsia, and others. Further, it is estimated that 70 percent of all antibiotics produced today are used in agriculture and animal husbandry (Mellon and others, 2001). Antibiotics are routinely fed to livestock, poultry, and commercially raised fish to promote faster growth and to compensate for the crowded conditions in which these animals are raised (Sarmah and others, 2006). One major concern is that bacteria are developing resistance to some legacy antibiotics so that different antibiotics, new antibiotics, or combinations of antibiotics are now needed to treat some bacterial infections.

Hormones are chemical compounds manufactured in various body organs, such as the pineal gland, pituitary gland, thyroid, adrenal gland, ovaries, and testes. These compounds travel in the blood stream to send messages to other body organs to regulate their functions. Hormones affect growth, mood swings, metabolism, the immune system, and the reproductive cycle. Abnormalities in the production of hormones can lead to human-health problems such as Addison's disease, Cushing's disease, and diabetes (Hall, 2011). Only a small amount of a hormone is needed to alter cell metabolism. Thus, low concentrations of hormones in the environment may cause unwanted responses in organisms exposed to those hormones. Research provides compelling evidence that endocrine systems of certain fish and wildlife have been affected by chemical contaminants, resulting in development and reproductive problems. For example, feminization of fish has been documented (Iguchi and others, 2001), and intersex fish are common in the Potomac River Basin and elsewhere (Jobling and others, 2006; Hinck and others, 2006; Woodling and others, 2006; Blazer and others, 2007; Tyler and Jobling, 2008; Vajda and others, 2008). A 7-year long Canadian study in which a lake was dosed with low levels (5 nanograms per liter (ng/L)) of 17-alpha-ethynylestradiol (synthetic estrogen) over a 3-year period demonstrated that "continued inputs of natural and synthetic estrogens and estrogen mimics...could decrease the reproductive success and sustainability of fish populations" (Kidd and others, 2007). The animal sterols, cholesterol and 3-beta-coprostanol, are included in the hormone analysis and in the discussion of hormone compounds. The compounds included in the hormone analysis and their reporting levels are listed in table 2.

Organic wastewater compounds (OWCs) are substances associated with effluents from municipal wastewater-treatment plants. The list of OWCs includes but is not limited to detergent metabolites, fragrances, flavors, pesticides, industrial compounds, disinfectants, polycyclic aromatic hydrocarbons (PAHs), fire retardants, and plasticizers. Although many of these compounds have both point and non-point sources, they can be used as indicators of wastewater. Many of the OWCs commonly detected in wastewater effluents have known or suspected endocrine disrupting potential. The plant sterols, beta-sitosterol and beta-stigmastanol, are included in the OWC analysis and in the discussion of OWC compounds. The compounds included in the OWC analysis and their reporting levels are listed in table 3. 
Table 1. Pharmaceutical compounds analyzed in streamwater and streambed-sediment samples, medicinal uses, and reporting levels.

[NWIS, National Water Information System; NWQL, U.S. Geological Survey National Water Quality Laboratory, Denver Colorado; ORGL, U.S. Geological Survey Organic Geochemistry Research Laboratory, Lawrence, Kansas; na, not analyzed; --, no data; ng/L, nanograms per liter; $\mu \mathrm{g} / \mathrm{kg}$, micrograms per kilogram]

\begin{tabular}{|c|c|c|c|c|c|c|}
\hline \multirow[b]{2}{*}{$\begin{array}{l}\text { Compound } \\
\text { name }\end{array}$} & \multirow[b]{2}{*}{$\begin{array}{l}\text { Medicinal } \\
\text { use }\end{array}$} & \multirow[b]{2}{*}{$\begin{array}{l}\text { Analylizing } \\
\text { laboratory }\end{array}$} & \multicolumn{2}{|c|}{ Streamwater } & \multicolumn{2}{|c|}{ Streambed sediment } \\
\hline & & & $\begin{array}{l}\text { NWIS } \\
\text { parameter } \\
\text { code }\end{array}$ & $\begin{array}{l}\text { Reporting } \\
\text { level } \\
\text { (ng/L) }\end{array}$ & $\begin{array}{l}\text { NWIS } \\
\text { parameter } \\
\text { code }\end{array}$ & $\begin{array}{c}\text { Reporting } \\
\text { level } \\
(\mu \mathrm{g} / \mathrm{kg})\end{array}$ \\
\hline \multicolumn{7}{|c|}{ Nonprescription pharmaceuticals and metabolites } \\
\hline Acetaminophen & Analgesic & NWQL & 62000 & 12 & na & -- \\
\hline Ibuprofen & Analgesic & ORGL & 62014 & 25 & na & -- \\
\hline Para-xanthine ${ }^{1,2,3}$ & Caffeine metabolite & NWQL & 62030 & 10 & na & -- \\
\hline Codeine & Analgesic & NWQL & 62003 & 11 & na & -- \\
\hline Diphenhydramine & $\begin{array}{c}\text { Antihistamine, antimetic (anti- } \\
\text { nausea), sleep aid, sedative }\end{array}$ & NWQL & 62796 & 12 & na & -- \\
\hline \multicolumn{7}{|c|}{ Prescription pharmaceuticals } \\
\hline Carbamazepine & $\begin{array}{l}\text { Anticonvulsant and antimanic } \\
\text { agent }^{4}\end{array}$ & NWQL & 62793 & 9 & na & -- \\
\hline Dehydronifedipine & Antianginal & NWQL & 62004 & 11 & na & -- \\
\hline Diltiazem & Antihypertensive & NWQL & 62008 & 9 & na & -- \\
\hline Salbutamol & Antiasthmatic & NWQL & 62020 & 7 & na & -- \\
\hline Erythromycin & $\begin{array}{l}\text { Human antibiotic also used in } \\
\text { fish hatcheries }\end{array}$ & ORGL & 62797 & 8 & $\begin{array}{l}\text { Code not } \\
\text { established }\end{array}$ & $1-5$ \\
\hline $\begin{array}{l}\text { Erythromycin- } \mathrm{H}_{2} \mathrm{O} \\
\quad(\text { anhydro-erythromycin })^{2}\end{array}$ & Erythromycin metabolite & ORGL & 63674 & 8 & $\begin{array}{l}\text { Code not } \\
\text { established }\end{array}$ & -- \\
\hline Roxithromycin & Human Antibiotic & ORGL & 62895 & 5 & $\begin{array}{l}\text { Code not } \\
\text { established }\end{array}$ & $1-5$ \\
\hline Tylosin & $\begin{array}{l}\text { Veterinary antibiotic used on } \\
\text { cattle, swine, and poultry }\end{array}$ & ORGL & 62896 & 8 & $\begin{array}{l}\text { Code not } \\
\text { established }\end{array}$ & $1-5$ \\
\hline Virginiamycin & $\begin{array}{l}\text { Veterinary antibiotic used on } \\
\text { cattle and swine, also used in } \\
\text { ethanol fuel industry }\end{array}$ & ORGL & 62897 & 5 & $\begin{array}{l}\text { Code not } \\
\text { established }\end{array}$ & $1-5$ \\
\hline
\end{tabular}


Table 1. Pharmaceutical compounds analyzed in streamwater and streambed-sediment samples, medicinal uses, and reporting levels.-Continued

[NWIS, National Water Information System; NWQL, U.S. Geological Survey National Water Quality Laboratory, Denver Colorado; ORGL, U.S. Geological Survey Organic Geochemistry Research Laboratory, Lawrence, Kansas; na, not analyzed; --, no data; ng/L, nanograms per liter; $\mu \mathrm{g} / \mathrm{kg}$, micrograms per kilogram]

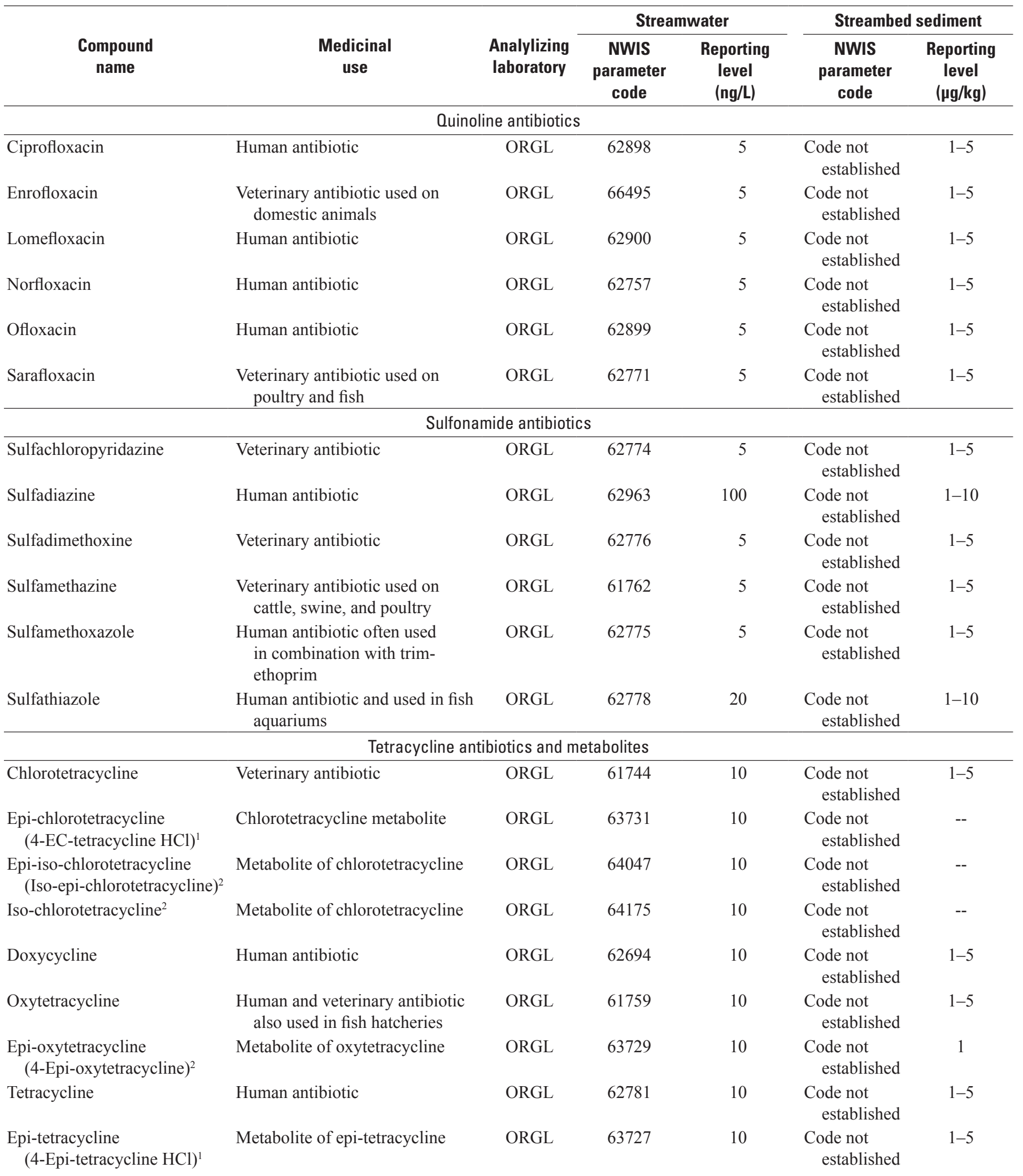


Table 1. Pharmaceutical compounds analyzed in streamwater and streambed-sediment samples, medicinal uses, and reporting levels.-Continued

[NWIS, National Water Information System; NWQL, U.S. Geological Survey National Water Quality Laboratory, Denver Colorado; ORGL, U.S. Geological Survey Organic Geochemistry Research Laboratory, Lawrence, Kansas; na, not analyzed; --, no data; ng/L, nanograms per liter; $\mu \mathrm{g} / \mathrm{kg}$, micrograms per kilogram]

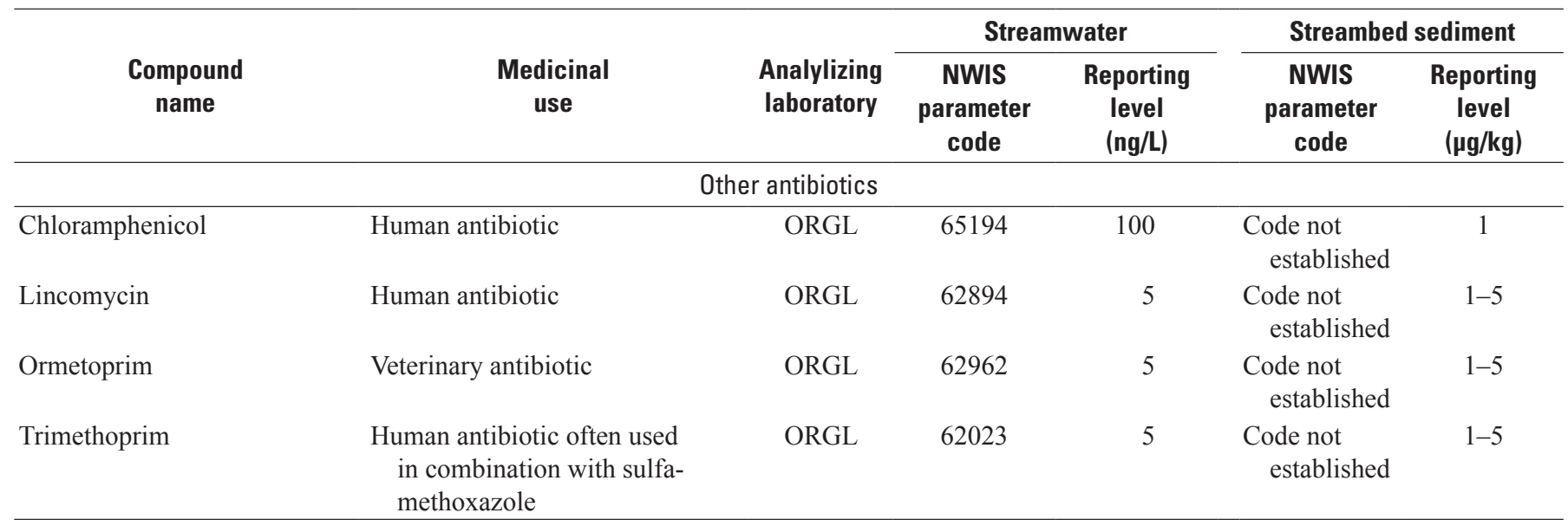

${ }^{1}$ Compounds are not strictly pharmaceuticals but are included in the pharmaceutical analysis because they are associated with human use.

${ }^{2}$ Metabolite breakdown product.

${ }^{3}$ Para-xanthine also know as 1,7 dimethylxanthine.

${ }^{4}$ Couper and Logan, 2004. 
Table 2. Hormones and animal sterols analyzed in streamwater and streambed-sediment samples, medicinal uses, and reporting levels.

[NWIS, National Water Information System; ng/L, nanograms per liter; $\mu \mathrm{g} / \mathrm{kg}$, micrograms per kilogram]

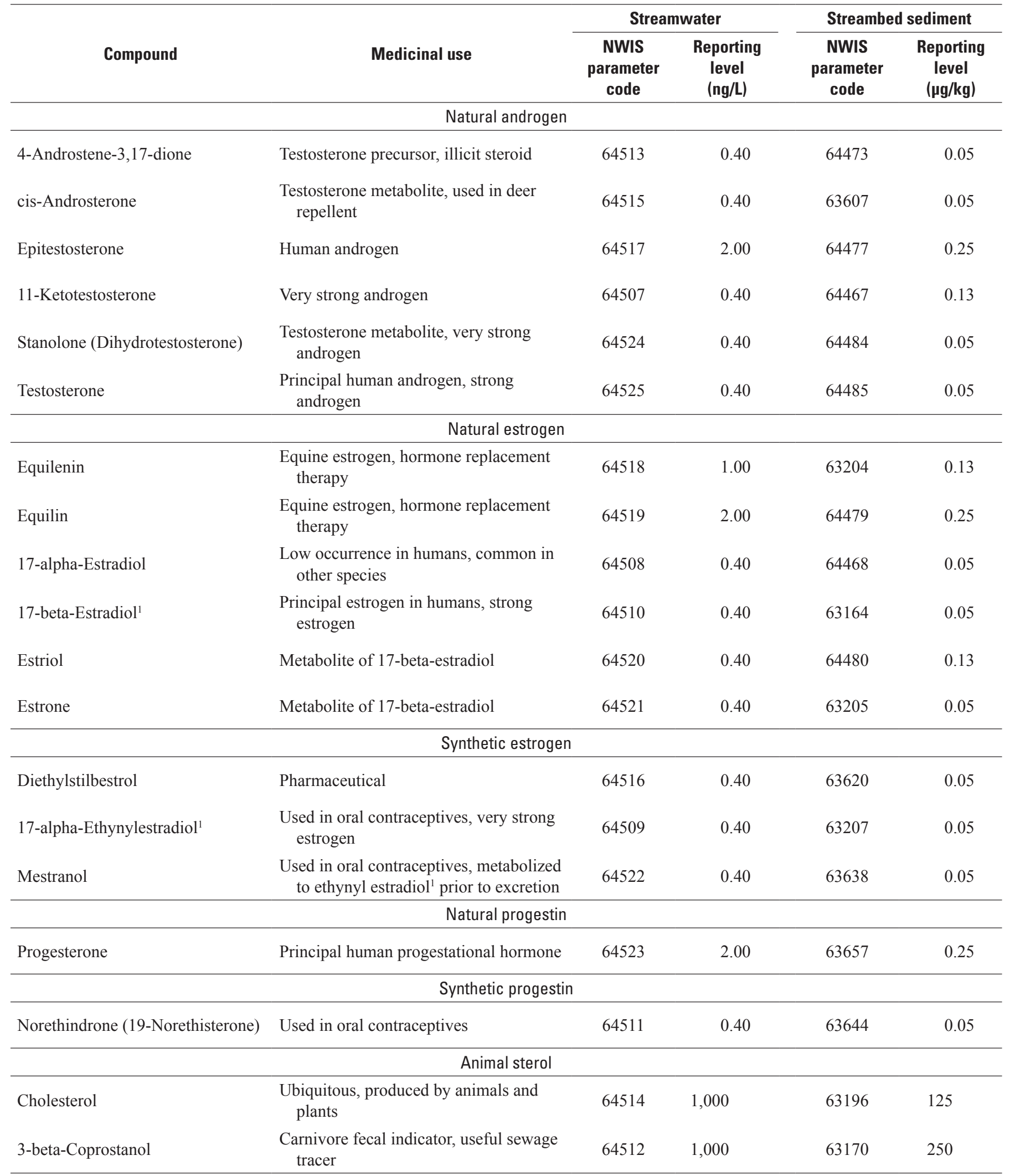

\footnotetext{
${ }^{1}$ Known endocrine disrupting potential.
} 
Table 3. Organic wastewater compounds analyzed in streamwater and streambed-sediment samples, uses or sources, and reporting levels.

[NWIS, National Water Information System; na, not analyzed; ng/L, nanograms per liter; $\mu \mathrm{g} / \mathrm{kg}$, micrograms per kilogram; --, no data; PAH, polycyclic aromatic hydrocarbon]

\begin{tabular}{|c|c|c|c|c|c|}
\hline \multirow[b]{2}{*}{ Compound } & \multirow[b]{2}{*}{ Use or sources } & \multicolumn{2}{|c|}{ Streamwater } & \multicolumn{2}{|c|}{ Streambed sediment } \\
\hline & & $\begin{array}{c}\text { NWIS } \\
\text { parameter } \\
\text { code }\end{array}$ & $\begin{array}{c}\text { Reporting } \\
\text { level } \\
\text { (ng/L) }\end{array}$ & $\begin{array}{c}\text { NWIS } \\
\text { parameter } \\
\text { code }\end{array}$ & $\begin{array}{c}\text { Reporting } \\
\text { level } \\
(\mu \mathrm{g} / \mathrm{kg})\end{array}$ \\
\hline \multicolumn{6}{|c|}{ Detergent metabolites } \\
\hline 4-Cumylphenol ${ }^{1}$ & Nonionic detergent metabolite & 62060 & 50 & 63173 & 34 \\
\hline 4-tert-Octylphenol ${ }^{1}$ & Nonionic detergent metabolite & 62062 & 50 & 63176 & 23 \\
\hline $\begin{array}{l}\text { Nonylphenol, diethoxy- (total, } \\
\text { NPEO2) }\end{array}$ & Nonionic detergent metabolite & 62083 & 2,500 & 63200 & 852 \\
\hline $\begin{array}{l}\text { Octylphenol, monoethoxy- } \\
(\text { OPEO1) }\end{array}$ & Nonionic detergent metabolite & 61706 & 500 & na & -- \\
\hline \multicolumn{6}{|c|}{ Fragrances and flavors } \\
\hline 3-Methyl-1H-indole (skatol) & Fragrance, stench in feces and coal tar & 62058 & 20 & 63171 & 31 \\
\hline Acetophenone & Fragrance in detergent and tobacco, flavor in beverages & 62064 & 50 & 63178 & 100 \\
\hline $\begin{array}{l}\text { Acetyl-hexamethyl-tetrahydro- } \\
\text { naphthalene (AHTN) }\end{array}$ & $\begin{array}{l}\text { Musk fragrance, persistent and widespread, in ground- } \\
\text { water, concern for bioaccumulation and toxicity }\end{array}$ & 62065 & 250 & 63179 & 13 \\
\hline Camphor & Flavor, odorant, ointments & 62070 & 30 & 63192 & 27 \\
\hline Isoquinoline & Flavors and fragrances & 62079 & 100 & 63214 & 83 \\
\hline Menthol & Cigarettes, cough drops, liniment, mouthwash & 62080 & 100 & 63215 & 42 \\
\hline \multicolumn{6}{|c|}{ Pesticides and degradates } \\
\hline 1,4-Dichlorobenzene ${ }^{2}$ & Moth repellant, fumigant, deodorant & 34572 & 20 & 63163 & 28 \\
\hline Atrazine & Herbicide & na & -- & 63182 & 59 \\
\hline Bromacil & $\begin{array}{l}\text { Herbicide, greater than } 80 \text { percent noncrop usage on } \\
\text { grass }\end{array}$ & 04029 & 200 & 63189 & 254 \\
\hline Carbaryl $^{1}$ & Insecticide, crop and garden uses, low persistence & 82680 & 500 & na & -- \\
\hline Carbazole & $\begin{array}{l}\text { Insecticide, manufacturing of dyes, explosives, and } \\
\text { lubricants }\end{array}$ & 62071 & 20 & 63194 & 22 \\
\hline
\end{tabular}


Table 3. Organic wastewater compounds analyzed in streamwater and streambed-sediment samples, uses or sources, and reporting levels.-Continued

[NWIS, National Water Information System; na, not analyzed; ng/L, nanograms per liter; $\mu \mathrm{g} / \mathrm{kg}$, micrograms per kilogram; --, no data; PAH, polycyclic aromatic hydrocarbon]

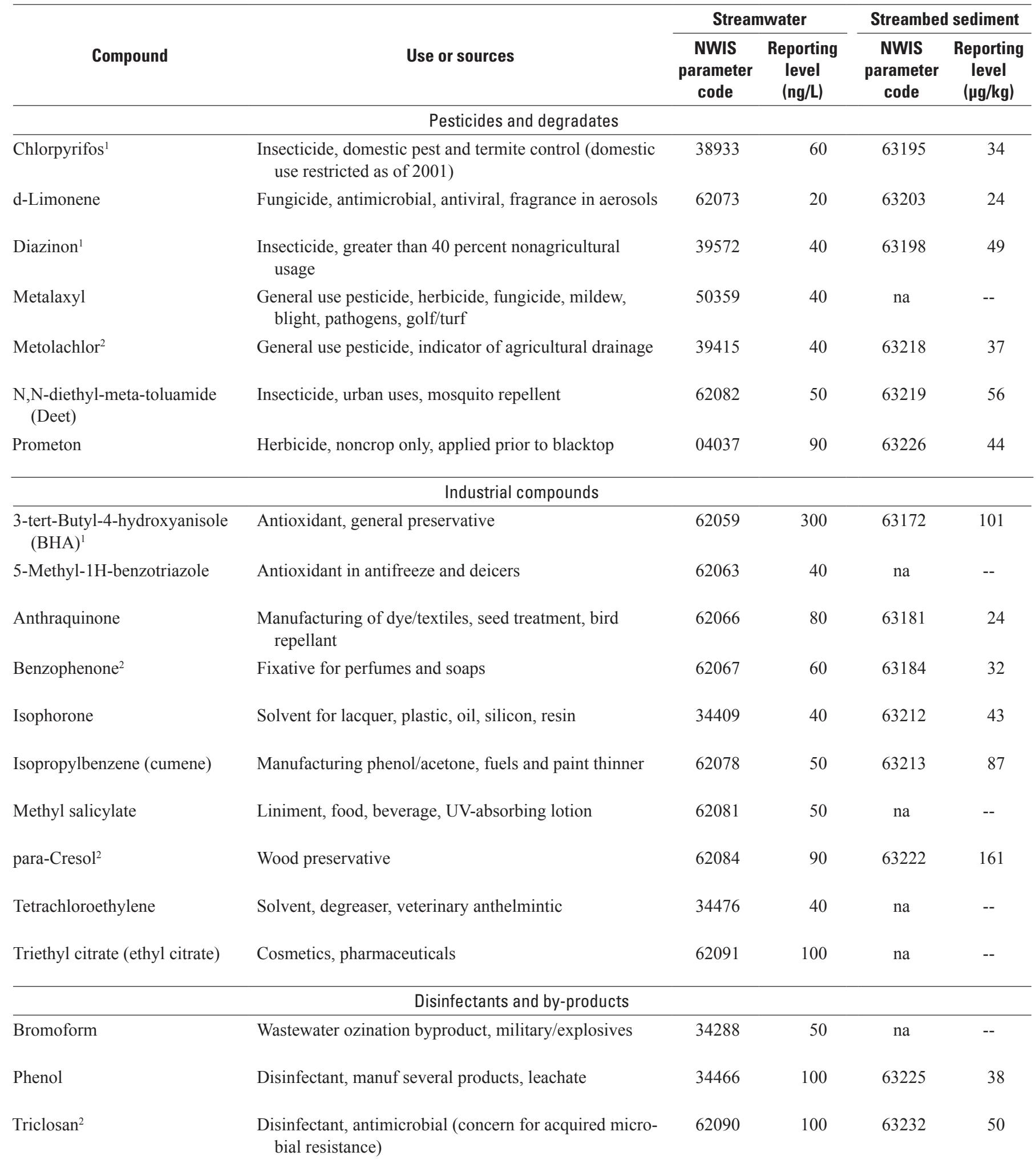


Table 3. Organic wastewater compounds analyzed in streamwater and streambed-sediment samples, uses or sources, and reporting levels.-Continued

[NWIS, National Water Information System; na, not analyzed; ng/L, nanograms per liter; $\mu \mathrm{g} / \mathrm{kg}$, micrograms per kilogram; --, no data; PAH, polycyclic aromatic hydrocarbon]

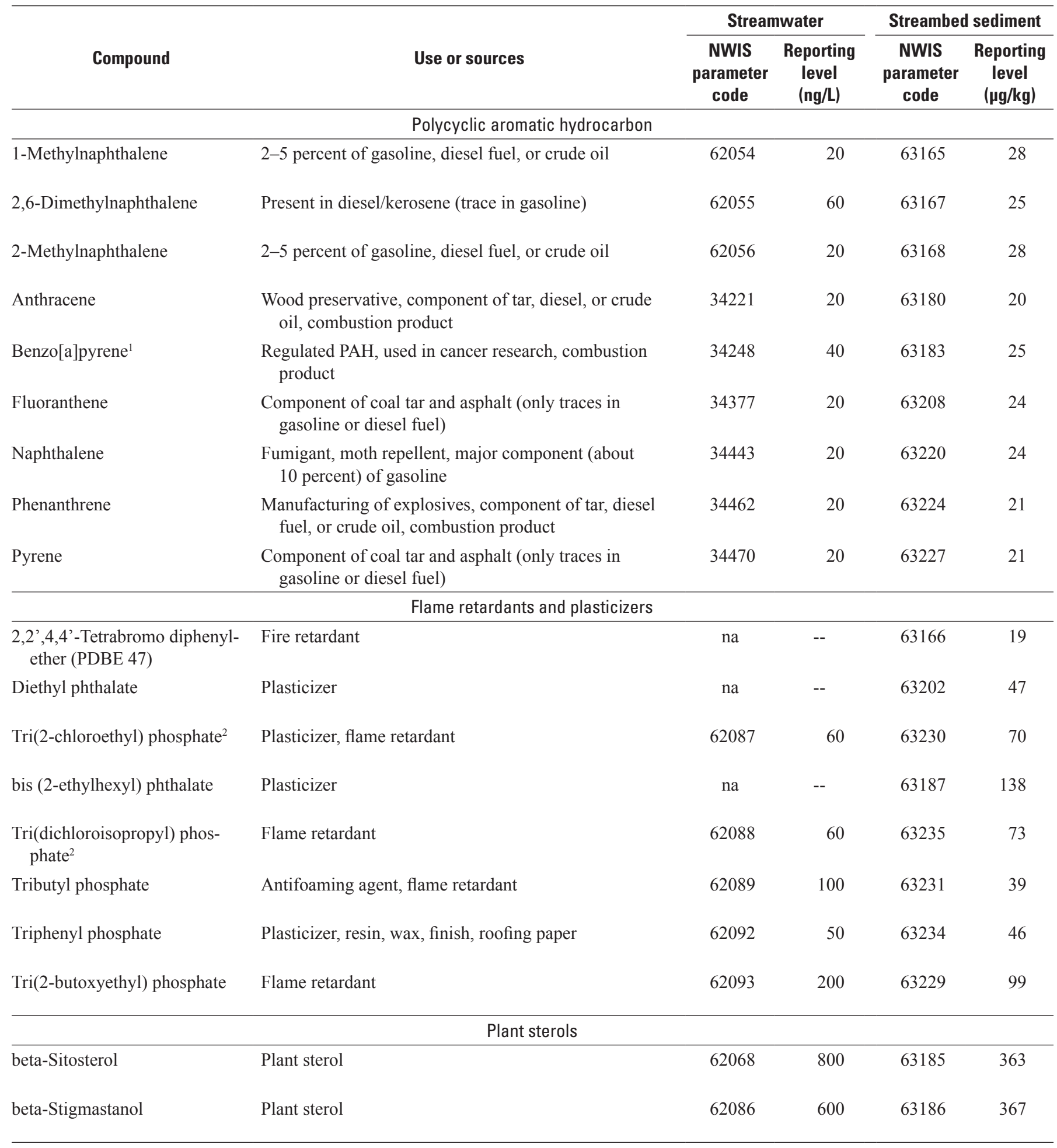

${ }^{1}$ Known endocrine disrupting potential.

${ }^{2}$ Suspected endocrine disrupting potential. 


\section{Potential Sources of Contaminants of Emerging Concern}

Thousands of chemical compounds fall under the classification of contaminants of emerging concern. As of June 2009, nearly 47.6 million organic and inorganic substances had been indexed by the American Chemical Society's Chemicals Abstracts Service (CAS) registry. Over 35 million of these chemicals were commercially available, though only 248,000 , or 0.5 percent, of these were inventoried or regulated by government bodies worldwide. Five years earlier, in March 2004, only 23 million organic and inorganic substances had been indexed, with 7 million commercially available and 230,000 inventoried and (or) regulated (American Chemical Society, 2010). The doubling of the number of compounds indexed and inventoried from 2004 to 2009 shows that the list of manmade chemical compounds is growing rapidly. Of the total list of compounds, the Pennsylvania reconnaissance sampling, on which this report is based, assessed a small fraction. Newly developed compounds are often available commercially before they have been inventoried, tested, or regulated.

\section{Agricultural Sources}

One path for the introduction of these contaminants to streamwater and groundwater is through land application of manure (Halling-Sorensen and others, 1998). Contaminants in manure may be transported to the groundwater system through recharge and reach the stream either through groundwater discharge or in surface-water runoff. For the agricultural sites included in this study, there was no confirmation that waste products from the agricultural operations were applied to land within the drainage area of the reach of the stream sampled or even applied to land within the same watershed.

\section{Wastewater Effluents}

Streams receiving wastewater-effluent discharges have been documented to contain detectable concentrations of contaminants of emerging concern (Halling-Sorensen and others, 1998; Ternes, 1998; Daughton and Ternes, 1999; Loraine and Pettigrove, 2006; Roberts and Thomas, 2006; Vajda and others, 2008; Jobling and others, 2009; Sellin and others, 2009). Wastewater-treatment plants can concentrate compounds from a larger area and discharge them into a stream as a single point source.

\section{Other Potential Sources of Contaminants of Emerging Concern}

Contaminants of emerging concern have been detected in streams that do not receive wastewater-effluent discharge or are not affected by agricultural land use, indicating that there are other non-point sources. Other potential sources that contribute contaminants of emerging concern to the environment exist, but they were not directly evaluated as part of this study. These sources include, but are not limited to, pharmaceutical manufacturer discharges, land application of biosolids, landfill leachate, combined sewer overflows (CSOs), and non-point sources including residential, commercial, and institutional on-site wastewater systems (septic systems). The present study did not consider locations of potential contaminant of emerging concern sources as a criterion for sampling-site selection.

\section{Pharmaceutical Manufacturing Facilities}

The findings from a national study, which focused on determining the contribution to the environment of contaminants of emerging concern from pharmaceutical manufacturers to wastewater-treatment plants, indicate that discharges from pharmaceutical manufacturing processes can increase pharmaceutical concentrations 10 to 1,000 times from those typically found in wastewater-treatment-plant effluents without such input (Phillips and others, 2010).

\section{Land Application of Biosolids}

Land application of biosolids to fertilize agricultural lands is common in Pennsylvania and presents yet another avenue by which contaminants of emerging concern can enter the environment. A study by Kinney and others (2006) evaluated nine different biosolid products produced by municipal wastewater-treatment plants in seven different states for 87 different OWCs. Results showed that a minimum of 30 and a maximum of 45 compounds were detected in any one biosolid sample. OWCs detected in biosolids can either infiltrate into groundwater and enter streams through base flow or act as a nonpoint source and enter streams in runoff. Contaminants of emerging concern also have been detected in crops and earthworms from land to which biosolids have been applied (Boxall and others, 2006; Kinney and others, 2008).

\section{Landfill Leachate}

Leaching from defective or poorly engineered landfills also can be a potential source of contaminants of emerging concern in water. Contaminants that have been sent to landfills are subject to biologic degradation processes; however some compounds that are resistant to degradation may leach into groundwater (Barnes and others, 2004). In a study by the Maine Department of Environmental Protection (2010), tests were conducted on leachate from three landfills in Maine. Results of laboratory analysis indicate that low concentrations of pharmaceuticals were present in the leachate as a result of the disposal of pharmaceuticals in household waste. In properly functioning landfills, leachate is collected and sent to a wastewater-treatment plant for treatment. 


\section{Combined Sewer Overflows}

Combined sewer overflows occur during storm runoff when sanitary waters bypass treatment plants and combine with stormwater that discharges directly to a stream. This untreated wastewater is a potential source of contaminants of emerging concern. A study by Philips and Chalmers (2009) evaluated the concentrations of OWCs in wastewater-treatment-plant effluent and combined sewer overflow (CSO) effluent. Results indicate that OWCs that are effectively removed through wastewater treatment were found in CSO effluent at concentrations equal to or greater than concentrations found in wastewater-treatment-plant effluent. OWCs that undergo little removal through wastewater treatment were found in CSO effluent at concentrations less than concentrations found in wastewater-treatment-plant effluent.

\section{On-Site Wastewater Systems}

On-site wastewater disposal systems (septic systems) have the potential to introduce contaminants of emerging concern into groundwater and ultimately into streams through base flow (Carrara and others, 2008). A U.S. Geological Survey study to determine the effect of on-site wastewater disposal on the quality of groundwater and base flow in Chester County, Pa., found that 30 OWCs were present in low levels, particularly in residential areas with a high density of on-site wastewater-disposal systems. Of the groundwater samples analyzed, more compounds were detected in samples from springs than in samples from wells. (Senior and Cinotto, 2007).

Similarly, a study of groundwater quality conducted in Adams County, $\mathrm{Pa}$., reported that six different OWCs were detected out of the 67 compounds analyzed in six wells (Low and Conger, 2002). Concentrations ranged from 0.02 to 1.2 micrograms per liter. Detections of some contaminants of emerging concern in groundwater also were documented in another study in Pike County, Pa. (Senior, 2009). Again, the potential for on-site wastewater systems to contribute these contaminants to groundwater and subsequently to streams was confirmed. The present study did not evaluate groundwater quality in areas served by on-site wastewater systems.

\section{Previous and Current Investigations}

Several studies of contaminants of emerging concern in streams and groundwater have been conducted in the last decade. Work on a national scale includes Terns, 1998; Kolpin and others, 2002; Jobling and others, 2006; Barnes and others, 2008; Focazio and others, 2008. Work focused on individual states, watersheds, or streams includes Chambers and Leiker, 2006; Roberts and Thomas, 2006; Woodling and others, 2006; Oblinger and others, 2007; Alvarez and others, 2008; Tertuliani and others, 2008; Haack, 2009; Damschen and Lundgren, 2009.
A few streamwater and groundwater samples from Pennsylvania were included in the national surveys by Kolpin and others (2002) and Barnes and others (2008), respectively; some contaminants of emerging concern were detected in the samples. Organic wastewater compounds were detected in base-flow and well-water samples in Chester County, Pa., (Senior and Cinotto, 2007; Senior and Sloto 2010) and in well-water samples in Adams County, Pa., (Low and Conger, 2002) and Pike County, Pa., (Senior, 2009) in areas with onsite wastewater disposal. Findings from these studies indicate that some of the contaminants of emerging concern enter the groundwater from surface or near-surface sources, such as septic systems, and may travel in groundwater discharge to streams.

Although some local or limited reconnaissance data have been collected on the occurrence of contaminants of emerging concern in selected areas of Pennsylvania, such as those reported by Low and Conger (2002) and Senior and Cinotto (2007), no comprehensive survey has been conducted for Pennsylvania waters to document the occurrence and distribution of these contaminants. The U.S. Geological Survey (USGS), in cooperation with the Pennsylvania Department of Environmental Protection (PADEP), Bureau of Water Quality Standards and Facility Regulation, conducted several reconnaissance studies from 2006 to 2009 to provide data to determine whether these compounds are present in Pennsylvania waters and, if so, which compounds are present and at what concentrations. As part of these USGS studies done in cooperation with PADEP, likely sources of the contaminants of emerging concern were confirmed, and an assessment of the possible environmental health implications was provided.

In addition to the study on which this report is based, two companion studies regarding contaminants of emerging concern in Pennsylvania waters were conducted. The first study was undertaken by scientists at the USGS Leetown Science Center National Fish Health Research Laboratory (2008-09); the study provided an assessment of fish health in Pennsylvania streams, targeting two species of fish, smallmouth bass (Micropterus dolomieu) and white sucker (Catostomus commersonii). The fish were subjected to external examinations, chemical analyses, and histopathological evaluations (V.S. Blazer, U.S. Geological Survey, written commun., 2009). The second study was conducted by scientists at the USGS Michigan Water Science Center (2007-09) and involved the identification of bacterial contamination at stream sites near drinking-water intakes. Factors associated with the occurrence of pathogenic bacteria were evaluated (J.W. Duris, U.S. Geological Survey, written commun., 2009).

The pharmaceutical and antibiotic data collected in 2006 as part of the initial reconnaissance sampling for the current study were presented in a data series report by Loper and others, (2007). Other contaminant of emerging concern data from the 2007 to 2009 sampling have been published in the USGS annual Water Data Reports for 2006 to 2009 (U.S. Geological Survey, 2007-09). 


\section{Study Design}

The overall design of the study was built around three separate reconnaissance sampling efforts conducted from 2006 to 2009. Each component was designed to assess a different environmental issue and each component was designed to help address one of the overall study objectives (table 4).

One reconnaissance sampling effort was designed to confirm suspected source(s) of contaminants of emerging concern. Three components of the study addressed this issue (table 4).

1. Analysis of water samples from wells used to supply livestock allowed for an evaluation to determine whether agricultural operations nearby represent a source of contaminants of emerging concern to groundwater.

2. Analysis of streamwater samples collected upstream and downstream from animal-feeding operations (AFOs) allowed for evaluation of contributions of contaminants of emerging concern from agriculture to surface water.

3. Analysis of streamwater samples collected upstream and downstream from municipal wastewater-effluentdischarge sites allowed for an evaluation of contributions from wastewater-treatment plants.

Streambed-sediment samples also were collected at sites located downstream from municipal wastewater-effluentdischarge sites. All the sampling locations for the first three components of the study were in south-central Pennsylvania (fig. 1). South-central Pennsylvania was chosen as the sampling location because of its long history of agricultural land use. The area also contains numerous small streams that are affected by AFOs and wastewater-effluent discharges. Wells in limestone watersheds were selected to increase the possibility of contaminant detections. Limestone aquifers can transport contaminants to groundwater faster than aquifers in other rock types, making detection of contaminants more likely.

A second reconnaissance sampling effort was designed to evaluate the occurrence of contaminants of emerging concern in water used as sources for public drinking water. For this part of the study, 27 stream-sampling locations within 5 miles of drinking-water intakes were selected from the 157 sites in the Pennsylvania Water Quality Network (WQN). The WQN is an ambient fixed-station network operated by the PADEP Bureau of Water Standards and Facility Regulation. Sites selected for sampling are all within 5 miles of a drinkingwater intake. This component was designed to determine whether or not contaminants of emerging concern are present in intake waters that supply drinking water to Pennsylvania residents (fig. 2).

A third reconnaissance sampling effort was designed to evaluate the possible effects of contaminants of emerging concern on aquatic organisms. For this part of the study, streamwater and streambed-sediment samples from 16 stream sites across Pennsylvania were analyzed (fig. 2). Sites are located in all three major river basins and upstream and downstream from suspected contaminant sources. Concurrently, fish were collected and examined for a number of fish-health indicators including external and internal anomalies, histopathological, and physiological markers. The correlation of fish health indicators with the occurrence and concentrations of contaminants of emerging concern was addressed in a companion study done by the USGS (V.S. Blazer, U.S. Geological Survey, written commun., 2012)

\section{Methods}

Methods used for site selection, streamflow measurements, field water-chemistry measurements, water-quality sampling and processing, laboratory analyses, data analysis, and quality assurance and quality control are described in this section.

\section{Site Selection and Sampling Locations}

Each component of the study required sampling sites within specific environmental settings. Five different types of sampling sites were selected.

1. Wells in agricultural areas used to supply livestock,

2. Streams receiving runoff from AFOs,

3. Streams receiving municipal wastewater effluent,

4. Streams used for public drinking-water sources, and

5. Streams used for fish-health evaluations.

\section{Wells in Agricultural Areas Used to Supply Livestock}

Six wells in agricultural areas used to supply livestock were sampled quarterly in 2006; samples were analyzed for pharmaceutical compounds (table 1). Wells selected for sampling (table 5; fig. 1) met the following criteria:

1. Located in the south-central Pennsylvania study area,

2. Currently used to supply water for livestock on a farm,

3. Used on a daily basis,

4. Shallow (less than or equal to a total depth of 300 feet (ft)),

5. Completed in a limestone aquifer, and

6. Documented driller records of completion on file with the homeowner or the Pennsylvania Geological Survey that would provide confirmation of the well depth and aquifer lithology.

Sampled wells range in depth from 147 to $300 \mathrm{ft}$. Characteristics for each individual well are listed by Loper and others (2007). 


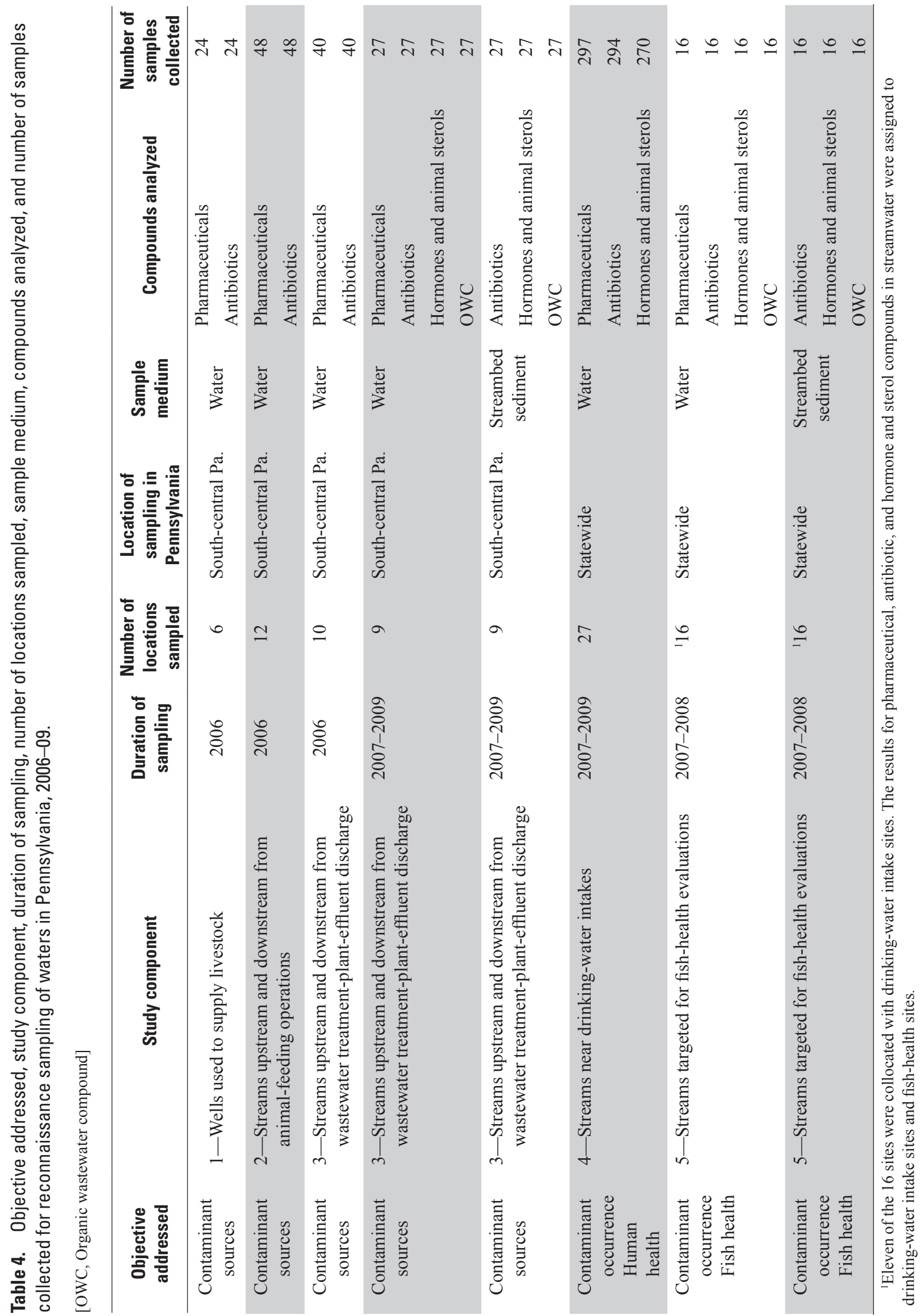




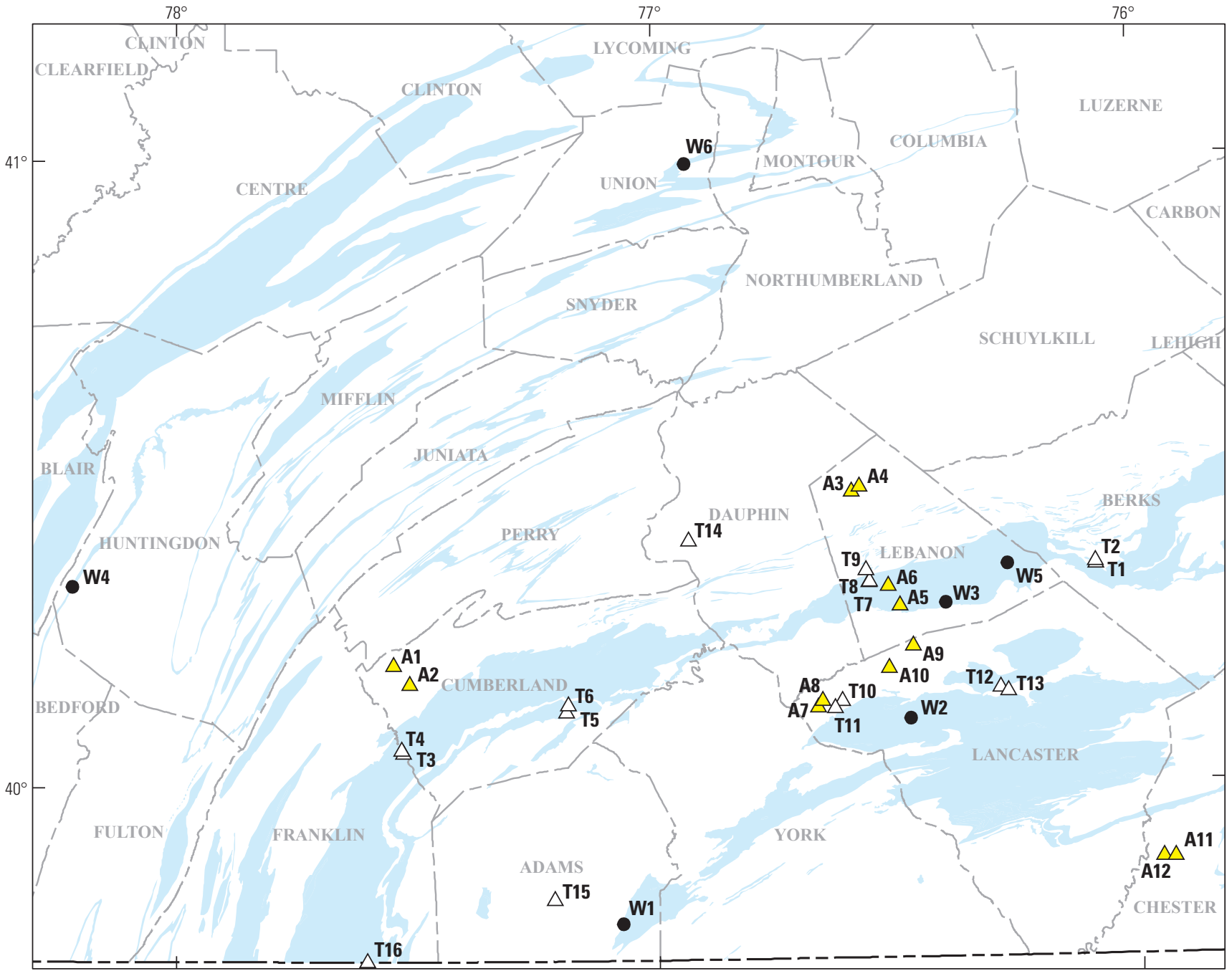

Base from U.S. Geological Survey digital data, 1980, 1:100,000 Albers Equal-Area Conic projection, NAD 83
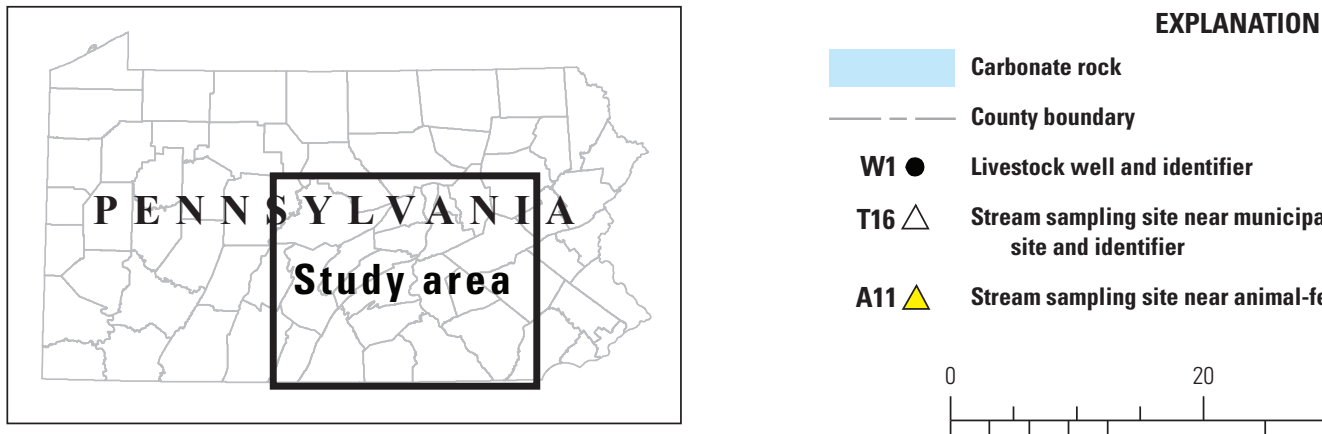

W1 Livestock well and identifier

T16 $\triangle$ Stream sampling site near municipal wastewater-effluent-discharge site and identifier

A11 $\triangle$ Stream sampling site near animal-feeding operation and identifier

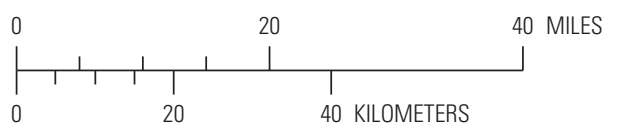

Figure 1. Locations of wells used to supply livestock, stream-sampling sites near animal-feeding operations, and stream-sampling sites near municipal wastewater-effluent-discharge sites, south-central Pennsylvania. 


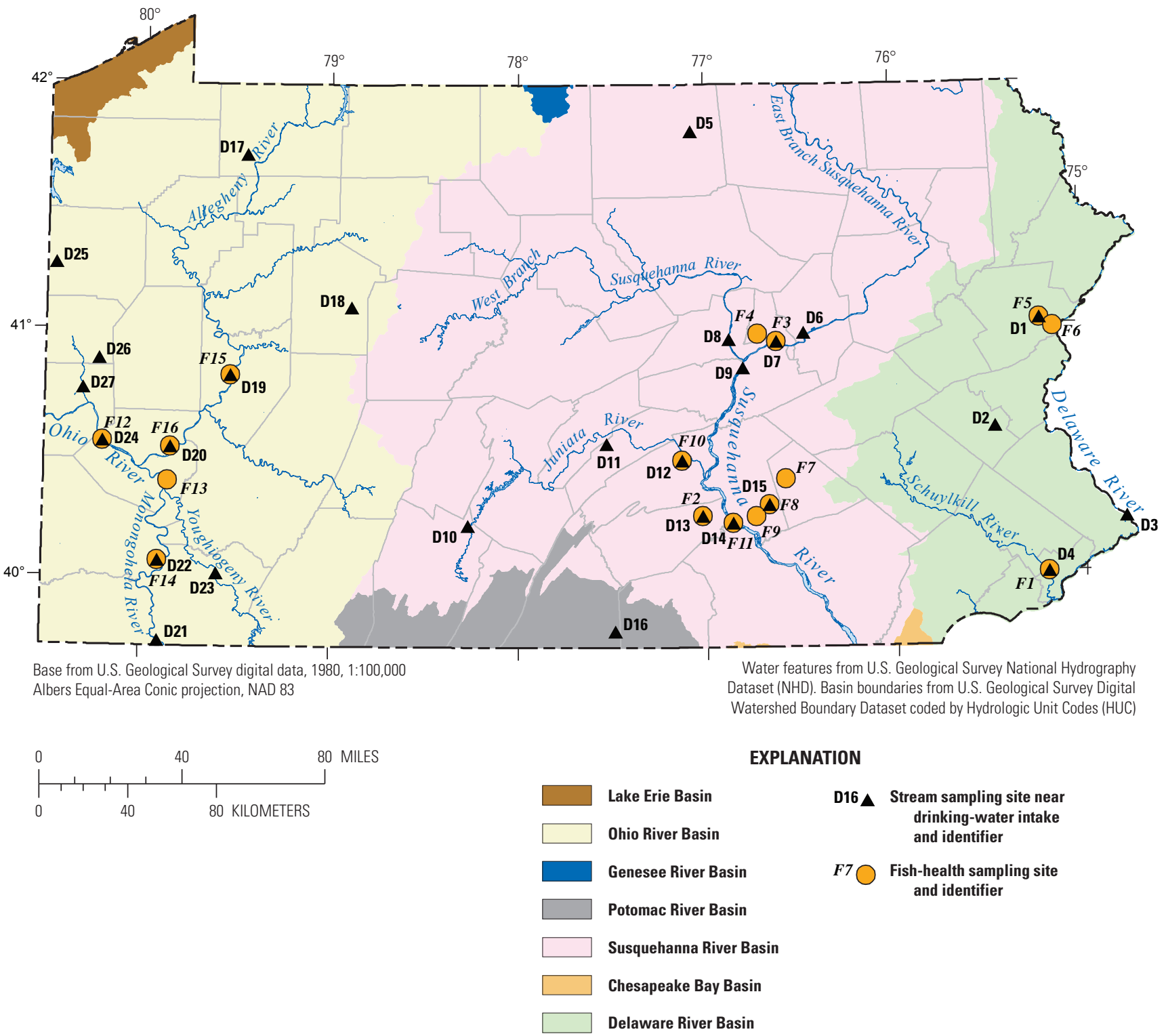

Figure 2. Locations of stream-sampling sites located near drinking-water intakes and sampling sites for evaluation of fish health in Pennsylvania. 
Methods 17

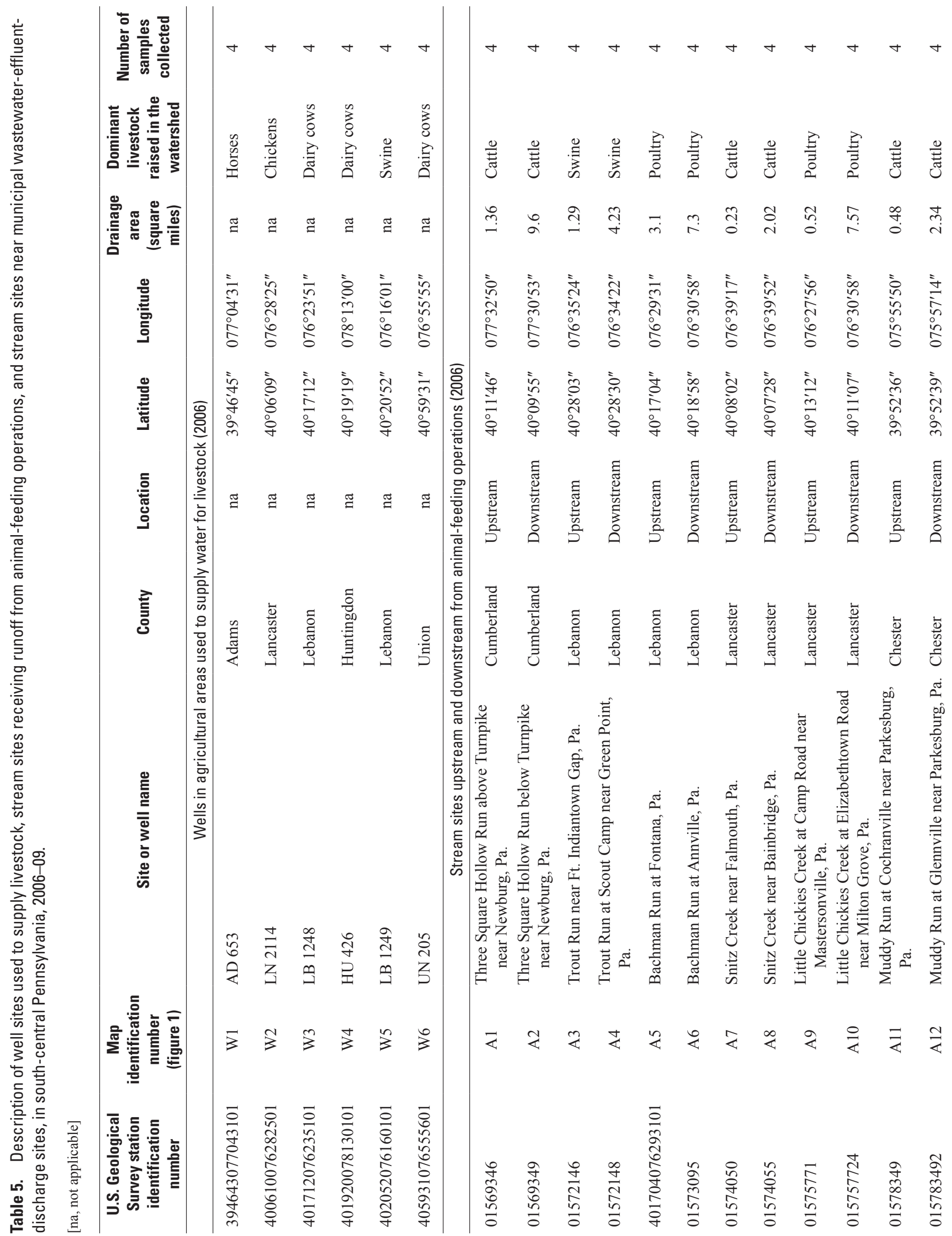




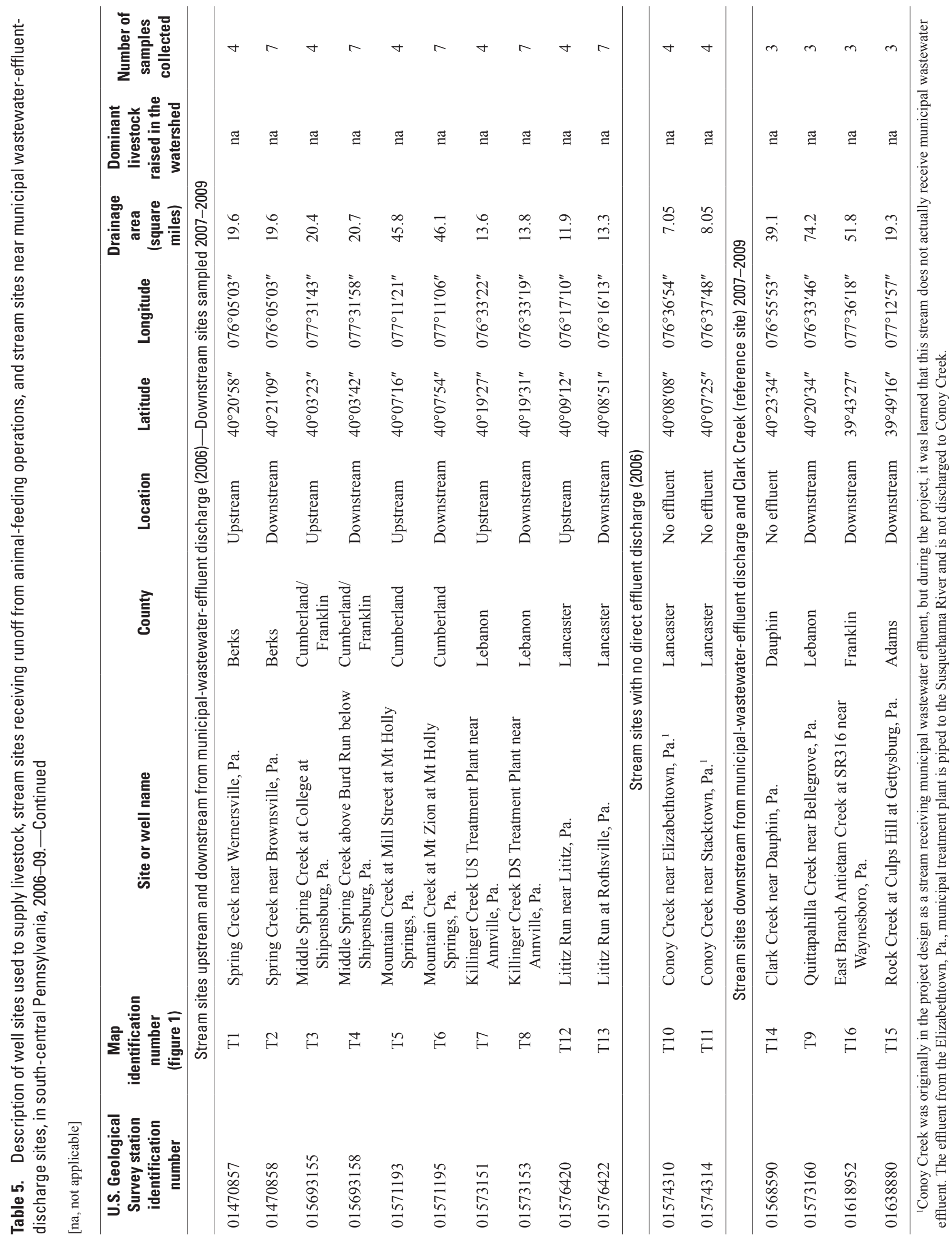




\section{Streams Draining Areas with Animal-Feeding Operations}

At six paired stream sites, samples of streamwater were collected quarterly in 2006 for analysis of pharmaceutical compounds. Each paired stream site consisted of a site upstream and a site downstream from an AFO. The USGS and County Conservation District together determined the locations of stream sites with AFOs nearby (table 5, fig. 1) that met the following criteria:

1. In an agricultural setting that included AFOs,

2. Located in south-central Pennsylvania,

3. Small drainage area (less than 10 square miles $\left(\mathrm{mi}^{2}\right)$ ), so that agricultural inputs would be the primary land-use influence on the stream, and

4. Landowner permitted access to the stream upstream and downstream from AFOs.

\section{Streams Receiving Municipal Wastewater Effluents}

At six paired stream sites, samples of streamwater were collected quarterly in 2006 for analysis of pharmaceutical compounds (table 1). Each paired stream site consisted of a site upstream and a site downstream from a wastewater-treatment effluent-discharge area. Seven sites located downstream from a wastewater-treatment effluent-discharge area (four new sites and three of the downstream sites sampled in 2006) were sampled annually from 2007 to 2009 and analyzed for pharmaceutical compounds, hormones, and OWCs. PADEP and the USGS worked cooperatively to select sampling locations for streams receiving municipal wastewater discharge. Early in the study, PADEP provided the USGS with locations of municipal-wastewater-treatment plants. Streams selected (table 5; fig. 1) met the following criteria:

1. Streams received wastewater effluent from one of the municipal-wastewater-plant locations provided by PADEP,

2. Located in the south-central Pennsylvania study area,

3. Moderately small streams (drainage area less than $100 \mathrm{mi}^{2}$ ) so effects from the wastewater input potentially would be large, and

4. Landowner permitted access to the stream upstream and downstream from the wastewater discharge.

Stream sites selected on Spring Creek, Middle Spring Creek, Mountain Creek, Killinger Creek, and Lititz Run met these criteria. A sixth stream, Conoy Creek, also was selected, but during the study, it was learned that effluent from a wastewater-treatment plant thought to be discharging to Conoy Creek was discharging directly to the Susquehanna
River. Therefore, the Conoy Creek site could not be used to evaluate concentrations of compounds in streams receiving municipal wastewater, but the data from samples collected at the upstream and downstream sites on Conoy Creek are included in the report and discussed as background values in a basin dominated by agricultural land use. The Killinger Creek sites met the site-selection criteria, but following the sampling period study, staff learned of wastewater-treatment plant cleaning operations with the potential to alter water quality. Upon further discussions with staff from the plant discharging to Killinger Creek, it was learned that the cleaning process took place weekly on the same day. Three of the four samples (May, July, and September samples of 2008) at the downstream location on Killinger Creek were collected on the day of cleaning. Concentrations of compounds reported for this site, therefore, may not be representative of the normal wastewater effluent that enters Killinger Creek the other 6 days of the week.

Beginning in 2007, sampling continued at sites downstream from wastewater-treatment-plant effluent discharge but was discontinued at sites upstream from the wastewatertreatment-plant effluent discharge. Also starting in 2007, four additional sites were included in the sampling: three streams receiving wastewater effluents, Quittapahilla Creek, East Branch Antietam Creek, and Rock Creek and one stream that had no municipal wastewater effluents (reference stream), Clark Creek (table 5). Flow rates of the effluent discharges entering these streams along with the 7-day 10-year lowflow statistic (the average minimum streamflow that can be expected for 7 consecutive days once every 10 years) and the range of actual measured streamflows during the sampling effort are provided in table 6 .

\section{Stream Sites near Drinking-Water Intakes}

At 27 PADEP stream sites, quarterly samples of water were collected for analysis of pharmaceutical compounds and hormones. The PADEP WQN is an extensive network of 157 (for the year 2009) stream water-quality monitoring sites distributed throughout Pennsylvania. The WQN sites are sampled for a wide range of constituents, including field characteristics, major ions, nutrients, total dissolved solids, metals, phenols, and bacteria. Many of the WQN sites have long-term records for water quality, with data collected for three decades or more. For this study, 22 WQN sites within 5 miles of a public drinking-water intake were selected for sampling (table 7; fig. 2). Five additional WQN sites, Corey Creek (D5, 01516750), East Branch Antietam Creek (D16, 01618800), George Run (D17, 03015554), Pitchpine Run (D18, 03031690), and Youghiogheny River (D23, 03082500) were established for this study of contaminants of emerging concern (table 7; fig. 2). Four of these sites are located in small watersheds (drainage area less than $25 \mathrm{mi}^{2}$ ) with few or no permitted discharges. The Youghiogheny River site is in a large watershed $\left(1,326 \mathrm{mi}^{2}\right)$ that contains 187 permitted discharges upstream from the sampling location. The 27 stream 
sites sampled from 2007 to 2009 represented a wide range of geography, hydrology, land use, and drainage area. Drainage areas at the sites ranged from $1.82 \mathrm{mi}^{2}$ to $19,500 \mathrm{mi}^{2}$ (table 7).

\section{Stream Sites Used to Evaluate Fish Health}

At 16 stream sites (table 8), one-time-only samples of streamwater and streambed sediment were collected for analysis of pharmaceutical compounds, hormones, and OWCs. The fish-health sampling sites were selected to include locations in all three major river basins in Pennsylvania, the Delaware River, the Susquehanna River, and the Ohio River (fig. 2). The fish-health sampling sites were generally located on a large stream, and commonly a site upstream and a site downstream from potential emerging contaminant sources were selected. Eleven of the 16 fish-health sites were co-located with drinking-water intake sampling sites, and the pharmaceutical and hormone data from water samples are shared by both data sets (table 8). This allowed analytical results from drinkingwater intake samples to be used for the fish-health evaluations, thereby saving analytical costs.

Fish were collected at these same sites and examined for external and internal anomalies, histopathology, and physiological markers. The correlation of fish health indicators with the occurrence and concentrations of contaminants of emerging concern was the objective of this work by scientists at the USGS Leetown Science Center National Fish Health Research Laboratory. Only the chemical results are presented in this report.

\section{Streamflow Measurement and Water-Quality Characteristics}

Stream discharge was determined for each streamwater sample collected. Discharge was determined from the streamgage record for sampling locations near USGS continuous-record streamgaging stations. Stream discharge at sites without a USGS continuous-record streamgaging station was measured using documented USGS procedures (Rantz and others, 1982).

Field measurements of $\mathrm{pH}$, specific conductance, dissolved oxygen, and water temperature were made in the stream cross section at 3 to 11 locations (depending on the stream width) and vertically at six-tenths of the depth of the stream using a multi-parameter meter. Water characteristics were used to determine whether the stream was well-mixed from bank to bank and whether there was variability along the stream cross section as a result of depth. Meter calibration was performed at the beginning of each day's sampling and followed procedures documented in the USGS Techniques of Water-Resources Investigations (Wilde, variously dated). Field measurements and equipment accuracies are shown in table 9.

Table 6. Characteristics of wastewater-treatment plants discharging to study streams.

[Mgal/d, million gallons per day; $\mathrm{ft}^{3} / \mathrm{s}$, cubic feet per second; WWTP, wastewater-treatment plant; Q7-10, 7-day, 10 year low-flow statistic]

\begin{tabular}{|c|c|c|c|c|c|c|}
\hline \multirow[t]{2}{*}{ Name of wastewater-treatment plant } & \multirow{2}{*}{$\begin{array}{c}\text { Design } \\
\text { flow } \\
\text { (Mgal/d) }\end{array}$} & \multirow{2}{*}{$\begin{array}{l}\text { Average } \\
\text { daily flow } \\
\text { for } 2008 \\
\text { (Mgal/d) }\end{array}$} & \multirow[t]{2}{*}{ Receiving stream } & \multicolumn{2}{|c|}{$\begin{array}{l}107-10 \text { flow at } \\
\text { downstream } \\
\text { sampling site }{ }^{2}\end{array}$} & \multirow{2}{*}{$\begin{array}{c}\text { Range of actual } \\
\text { measured stream } \\
\text { flows during sampling } \\
\left(\mathrm{ft}^{3} / \mathrm{s}\right)\end{array}$} \\
\hline & & & & Mgal/d & $\mathrm{ft}^{3} / \mathrm{s}$ & \\
\hline Robesonia-Wernersville Municipal Authority & 1.30 & 0.82 & Spring Creek & 2.91 & 4.51 & $13-33$ \\
\hline Borough of Shippensburg WWTP & 3.30 & 1.74 & Middle Spring Creek & 4.39 & 6.79 & $11-30$ \\
\hline Borough of Palmyra WWTP & 1.42 & 0.86 & Killinger Creek & 2.88 & 4.45 & $1.3-31$ \\
\hline Lititz Sewer Authority WWTP & 3.85 & 2.86 & Lititz Run & 0.43 & 0.66 & $9.3-45$ \\
\hline Gettsburg Municipal Authority & 2.45 & 1.67 & Rock Creek & 0.41 & 0.63 & $0.8-2.0$ \\
\hline Washington Township Municipal Authority & 1.94 & 0.88 & East Branch Antietam Creek & 6.53 & 10.10 & $17-34$ \\
\hline Borough of Palmyra & 1.42 & 0.86 & Quittapahilla Creek & 30.70 & 47.50 & $75-96$ \\
\hline
\end{tabular}

${ }^{1} \mathrm{Q} 7-10$ flow is the average minimum streamflow that can be expected for 7 consecutive days once every 10 years.

${ }^{2}$ Estimated using U.S. Geological Survey StreamStats (Stuckey, 2006). 


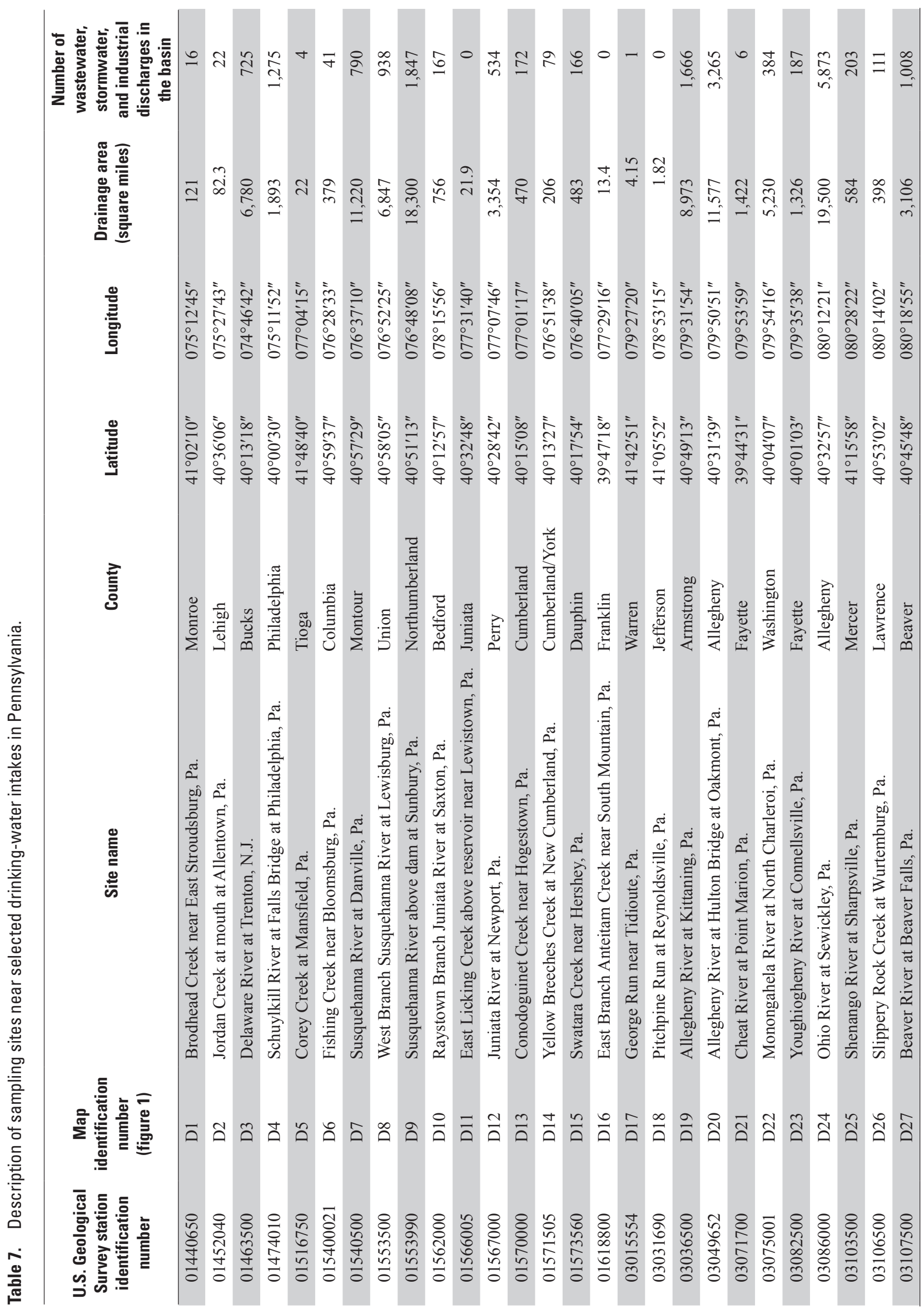




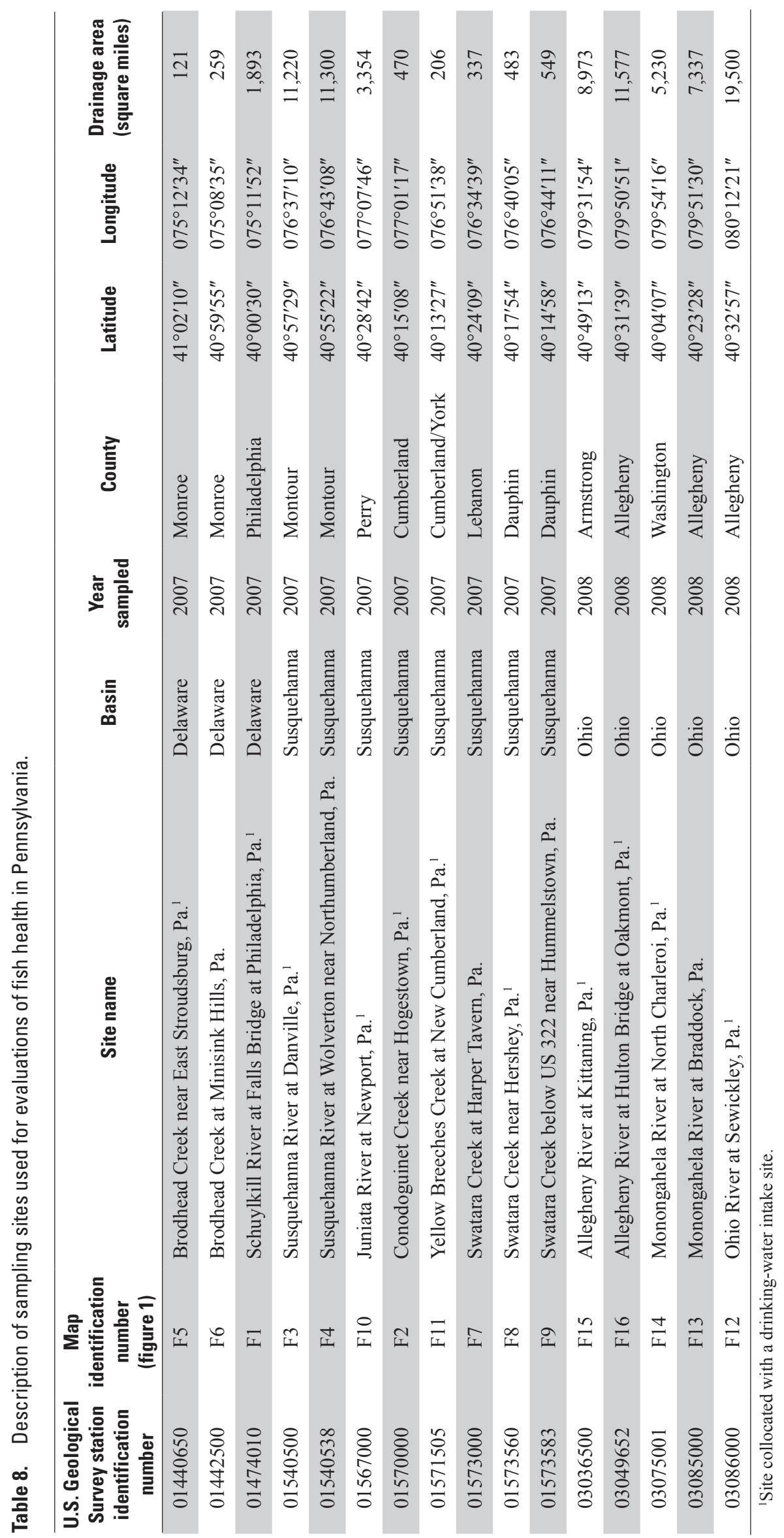


Table 9. Description of field measurement with reporting units and instrument reporting accuracies used in this study.

[NWIS, National Water Information System; $\mathrm{ft}^{3} / \mathrm{s}$, cubic feet per second; ${ }^{\circ} \mathrm{C}$, degrees Celsius; $\mu \mathrm{S} / \mathrm{cm}$, microsiemens per centimenter at $25^{\circ} \mathrm{C} ; \mathrm{mm}$, millimeters; $\mathrm{mg} / \mathrm{L}$, milligrams per liter; \%, percent]

\begin{tabular}{lcll}
\hline \multicolumn{1}{c}{ Measurement } & NWIS code & Reporting units & \multicolumn{1}{c}{ Instrument reporting accuracy } \\
\hline Stream discharge & 00061 & $\mathrm{ft}^{3} / \mathrm{s}$ & $\pm 0.003 \mathrm{ft}^{3} / \mathrm{s}$ \\
Temperature & 00010 & ${ }^{\circ} \mathrm{C}$ & $\pm 0.15^{\circ} \mathrm{C}$ \\
$\mathrm{pH}$ & 00400 & standard units & \pm 0.2 \\
Specific conductance & 00095 & $\mu \mathrm{S} / \mathrm{cm}$ at $25^{\circ} \mathrm{C}$ & $\pm 0.5 \%$ of the reading or $1 \mu \mathrm{S} / \mathrm{cm}$, whichever is greater \\
Dissolved oxygen & 00300 & $\mathrm{mg} / \mathrm{L}$ & $\pm 2 \%$ of the reading or $0.2 \mathrm{mg} / \mathrm{L}$, whichever is greater \\
Barometric pressure & 00025 & $\mathrm{~mm}$ mercury & \pm 0.75 to $1.5 \mathrm{~mm}$ mercury \\
\hline
\end{tabular}

\section{Collection and Processing of Water-Quality Samples}

All sampling equipment was cleaned thoroughly prior to sample collection, following protocols for organic-compound sampling (Wilde, 2004). Special considerations for personal safety and sample integrity were followed when working with samples from streams receiving municipal wastewater or water from AFOs.

\section{Streamwater}

Streamwater samples were collected according to standard USGS field sample collection techniques (U.S. Geological Survey, 2006). Wadeable sites were sampled at intervals of equal width (minimum of 3 and a maximum of 11 locations) along the stream cross section by using a US DH-81 depthintegrated sampler fitted with a Teflon bottle and nozzle (U.S. Geological Survey, 2006; fig. 3). If the stream was too shallow or the stream velocities were less than 1.5 feet per second $(\mathrm{ft} / \mathrm{s})$ the US DH-81 sampler nozzle was removed, and samples were collected directly into the Teflon bottle. Non-wadeable sites were sampled at a minimum of nine locations along the stream cross section from a boat or a bridge by using a US DH-95 depth-integrating sampler fitted with a Teflon bottle and nozzle (U.S. Geological Survey, 2006). Each stream cross-section sub-sample was sequentially poured into a single pre-cleaned and stream-rinsed Teflon churn splitter and mixed, resulting in a homogenous composite sample. All locations of the verticals were noted on the field data sheets. Specific streamflows were not targeted during sampling. Reconnaissance sampling upstream and downstream from AFOs and wastewatertreatment effluent discharge generally were collected during base-flow conditions. Reconnaissance sampling at the drinking-water-intake and fish-health sites was conducted during a range of hydrologic conditions.

Sample processing and shipping protocols developed for pharmaceuticals, hormones, and OWCs were followed (Wilde and others, 2004 [update 5.6.1.F]). In brief, all streamwater samples were processed at the sampling site by filtering the composite sample using a peristaltic pump fitted with a Teflon head and hoses through a pre-cleaned 0.7 -micron glass fiber filter (GFF) that had been rinsed and preconditioned with sample water. Samples for analysis of pharmaceuticals and OWCs were filtered into amber glass bottles that had been cleaned and fired (baked at 450 degrees Celsius $\left({ }^{\circ} \mathrm{C}\right.$ ) to burn off all residual organic compounds). Samples for analysis of hormones were filtered into plastic bottles and frozen until thawed for analysis at the laboratory. Samples for analysis of antibiotics were shipped on ice overnight to the USGS Organic Geochemistry Research Laboratory (ORGL) in Lawrence, Kansas. All other streamwater samples were shipped on ice overnight to the USGS National Water Quality Laboratory (NWQL) in Denver, Colorado, for analysis.

\section{Groundwater}

Collection of groundwater samples followed protocols documented by the USGS National Field Manual for the Collection of Water-Quality Data (U.S. Geological Survey, 2006) with modifications. A modification to the protocol included the use of brass fittings instead of Teflon to connect to water sources; a flow manifold or processing chamber was not used. At all wells sampled, existing in-situ submersible pumps provided sample water to a tap either at the base of the pressure tank or at an outside faucet. As the well was purged, $\mathrm{pH}$, specific conductance, dissolved oxygen, and water temperature were monitored using a calibrated multi-parameter meter. When readings became stable (variation between five or more 5-minute sequential field-measurement values: \pm 0.05 units for $\mathrm{pH} ; \pm 0.2^{\circ} \mathrm{C}$ for water temperature; \pm 0.3 milligram per liter $(\mathrm{mg} / \mathrm{L})$ for dissolved oxygen; and \pm 3 percent for specific conductance greater than 100 microsiemens per centimeter $(\mu \mathrm{S} / \mathrm{cm}))$, the groundwater samples were collected. All groundwater samples were processed at the sampling site. A pre-cleaned Teflon in-line filter-unit holder with a baked, glass microfiber filter (47-millimeter ( $\mathrm{mm}$ ) diameter, 0.7-micrometer $(\mu \mathrm{m})$ pore-size) was used to filter the sample directly from the tap or faucet into two 1-liter (L) amber glass bottles cleaned and baked at $450^{\circ} \mathrm{C}$ to burn off all residual organic 


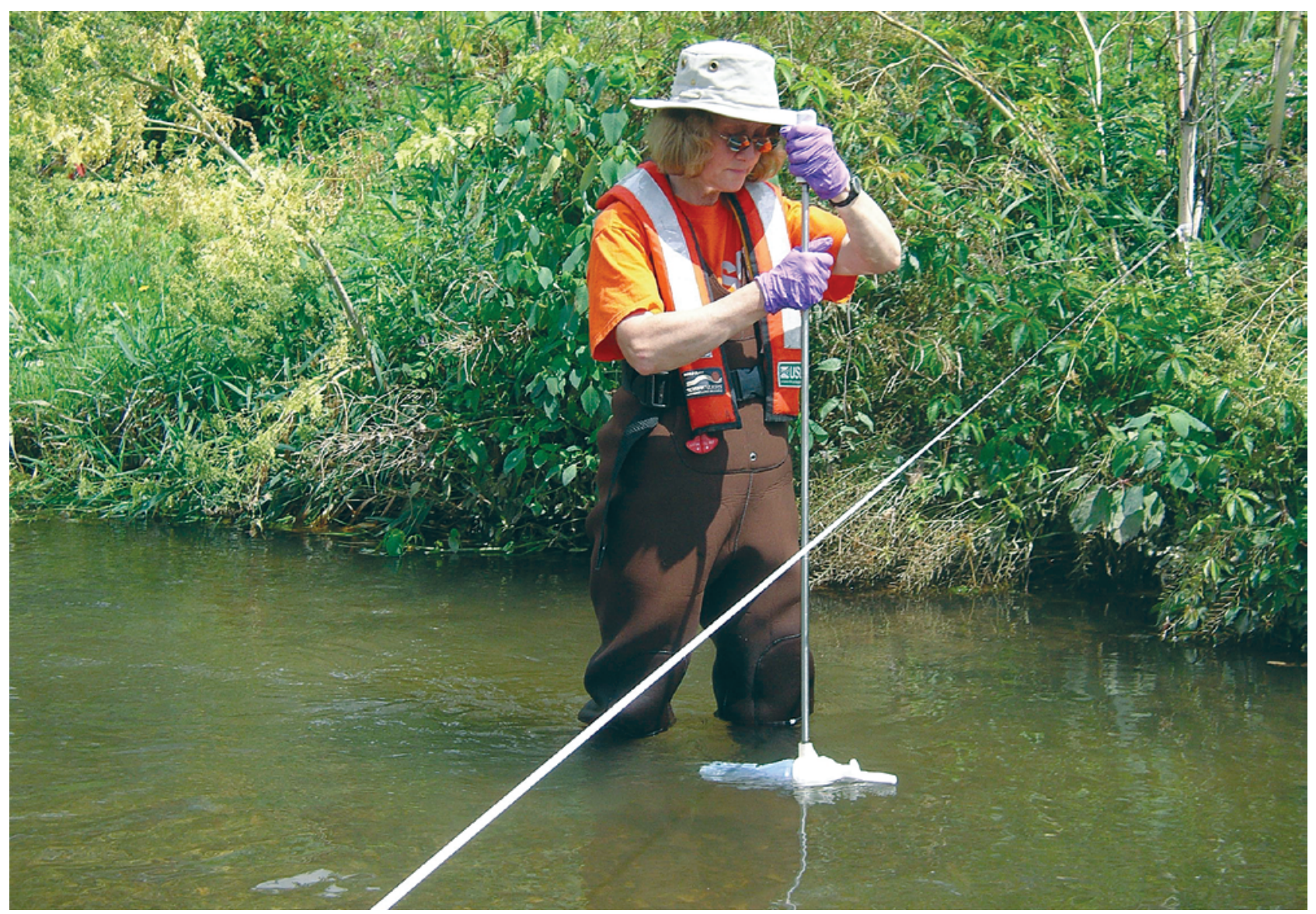

Figure 3. U.S. Geological Survey hydrologist collects a water sample for analysis of contaminants of emerging concern using a DH-81 sampler fitted with Teflon adapter, Teflon nozzle, and Teflon 1-L bottle.

compounds. One bottle was sent to the NWQL for analysis of pharmaceutical compounds (excluding antibiotics). The second bottle was held as an archive sample. Three 125-milliliter $(\mathrm{mL})$ cleaned-and-burned glass bottles were used to collect filtered water for antibiotic analyses. All sample bottles were kept chilled at $4^{\circ} \mathrm{C}$ until they were shipped to the NWQL or OGRL for analysis. All samples were double bagged and shipped on ice within 2 days of collection via overnight delivery to the analytical laboratories.

\section{Streambed Sediments}

Because organic compounds are known to adsorb preferentially to fine-grained sediments, deposits of fine-grained material were targeted for collection as streambed-sediment samples. Samples of streambed sediments were collected from five locations within $100 \mathrm{ft}$ of a sampling site using a Teflon cylinder (open at both ends) and wafer (fig. 4). The technique requires that the cylinder be inserted into the sediment to a depth of 2 centimeters $(\mathrm{cm})$ and the wafer be inserted underneath the cylinder, trapping sediment inside the cylinder. To the extent possible, sediment inside the cylinder was not disturbed. The five cylinders of streambed sediment collected near a stream-sampling site were composited in a pre-cleaned stainless steel bowl. Sediment in the bowl was thoroughly mixed, then sieved into a second stainless steel bowl. Sub-samples needed for laboratory analyses were placed into pre-cleaned $500 \mathrm{~mL}$ glass jars (fig. 5) that had been baked at $450^{\circ} \mathrm{C}$ to burn off all residual organic compounds. Sample jars were then placed on ice in the field. Upon return to the USGS office, the sample jar was frozen to a temperature of $-20^{\circ} \mathrm{C}$. The sample was shipped frozen to the analyzing laboratory where it remained frozen until thawed for analytical determinations.

\section{Laboratory Analyses}

The analytical methods used at NWQL and other USGS laboratories to determine contaminant of emerging concern concentrations are relatively new, having been developed within the last decade (Appendix A). Others methods are still in the development and testing phase, have not received USGS 


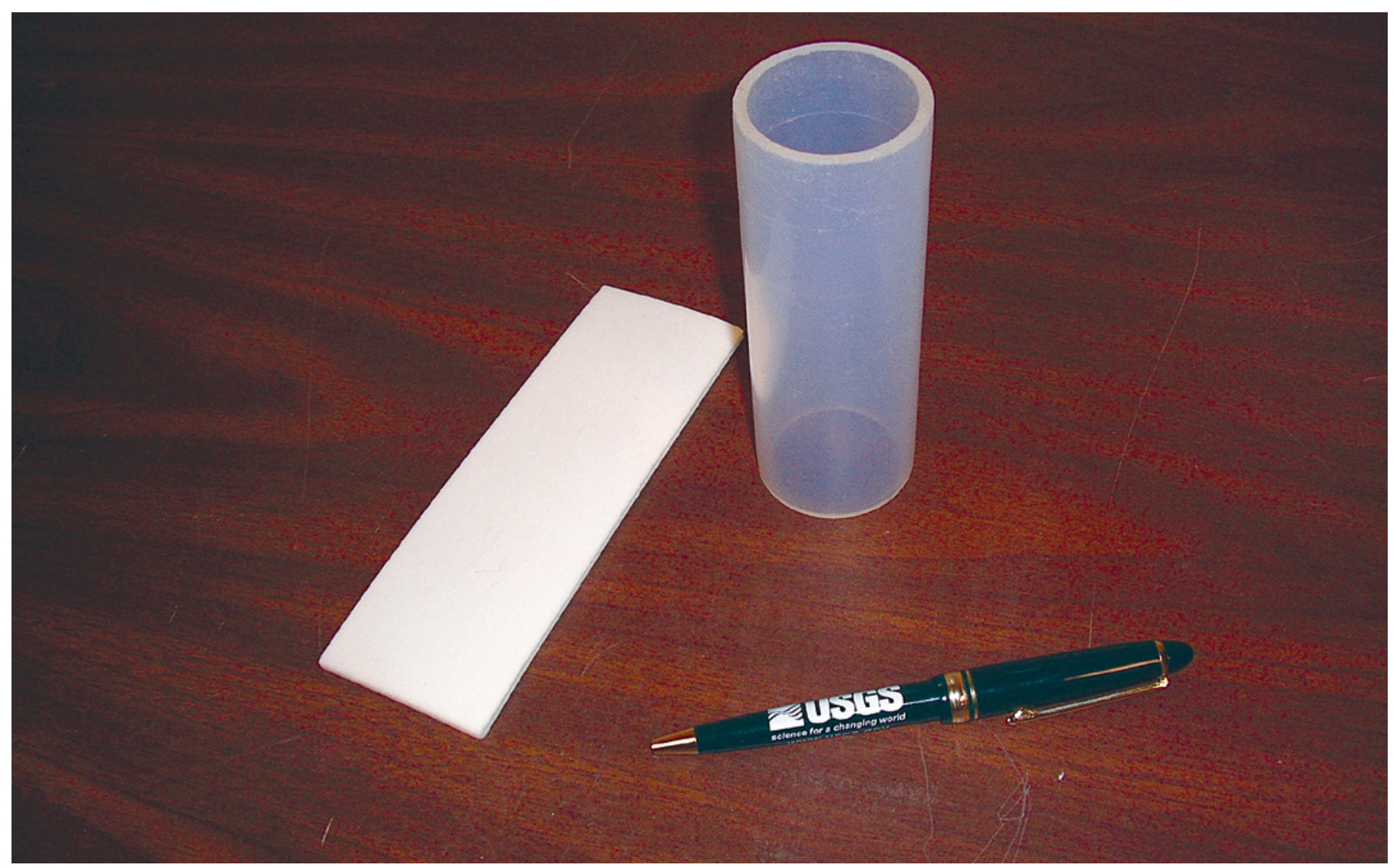

Figure 4. Teflon cylinder and Teflon wafer used to collect streambed-sediment samples.

approval, and were considered to be research methods as of 2009. As of 2011, the pharmaceutical (excluding antibiotics) and OWC analyses are performed at the NWQL using approved USGS methods. Antibiotic (table 1) and hormone and animal sterol (table 2) analyses are performed at ORGL and the NWQL using USGS research methods. Therefore, descriptions provided here for analytical methods in development will be detailed. The new analytical methods now allow for a number of additional contaminants of emerging concern in water and streambed sediments to be detected and quantified. These new methods have been developed by USGS researchers in Denver, Colorado, and in Lawrence, Kansas. The compounds analyzed using these techniques represent a combination of high-use compounds, compounds with a high probability of detection, and compounds with an analytical technique available to quantify their occurrence.

The minimum reporting level (MRL) is the smallest measured concentration of a substance that can be reliably measured by using a given analytical method. The method detection limit (MDL) is the minimum concentration of a substance that can be measured and reported with 99-percent confidence

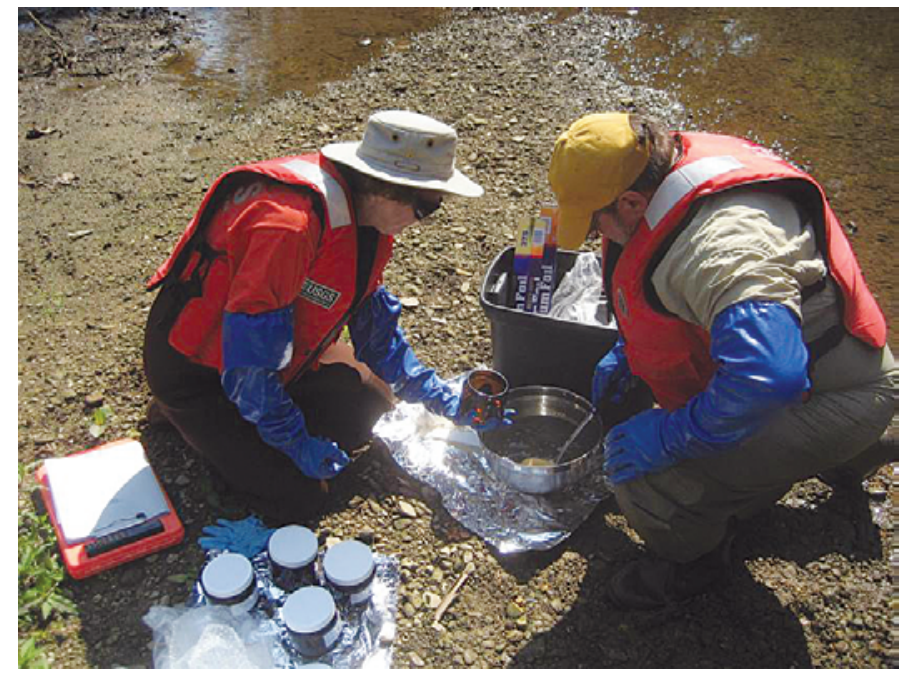

Figure 5. U.S. Geological Survey and Pennsylvania Department of Environmental Protection scientists processing a streambedsediment sample in the field. 
that the analyte concentration is greater than zero. The USGS NWQL has established a data reporting convention described in Childress and others (1999). An estimated concentration (qualifying remark code E) denotes a semi-quantitative result reported because it is outside the calibration range; it is commonly associated with detections greater than the MDL but below the MRL for that analyte. In this report, each compound had an established reporting level, which was based on either a MRL (antibiotics) or MDL (pharmaceuticals, excluding antibiotics, hormones, and OWCs). Estimated values greater than the reporting level were used in all data analysis.

\section{Streamwater Samples}

\section{Pharmaceutical Compounds}

Streamwater samples were analyzed for pharmaceutical compounds (excluding antibiotics) at the USGS NWQL in Denver, Colorado. The research analytical method consisted of a solid-phase extraction followed by high-performance liquid chromatography/mass spectrometry (HPLC-MS), using a polar reverse-phase octylsilane (C8) HPLC column following the procedure described in Cahill and others (2004) and Furlong and others (2008). All pharmaceutical compounds except for antibiotics and ibuprofen were analyzed at the USGS NWQL. The compounds included in the USGS NWQL pharmaceutical analysis and their reporting levels are listed in table 1.

\section{Antibiotics and Ibuprofen}

Antibiotics and ibuprofen were analyzed at the USGS OGRL in Lawrence, Kansas, using a research method modified from an online solid-phase extraction (SPE) method from Meyer and others (2007). Streamwater samples were analyzed for antibiotics and ibuprofen using online SPE and liquid chromatography/tandem mass spectrometry (LC/MS/MS) with electrospray ionization (ESI) and multiple reaction monitoring (MRM). This technique allowed quantitation of chloramphenicol, lincomycin, ormetoprim, trimethoprim, five macrolides, six sulfonamides, six quinolines, four tetracycline antibiotics, six antibiotic metabolite breakdown products, and ibuprofen.

The antibiotics analyzed at the USGS OGRL and their reporting levels are listed in table 1. Ibuprofen is analyzed at the USGS OGRL but is reported with the pharmaceuticals in table 1 . The reporting levels for the 31 compounds ranged from $1 \mathrm{ng} / \mathrm{L}$ to $10 \mathrm{ng} / \mathrm{L}$. The OGRL reported only concentrations greater than the MRLs for samples collected for this study.

\section{Hormones}

Streamwater samples were analyzed for hormones at the USGS NWQL in Denver Colorado. Filtered streamwater samples were fortified with deuterated analogs of 13 analytes as isotope dilution standards (IDSs), and the samples were poured into stainless steel extraction tubes equipped with a multigrade GFF over a 47-mm C18 solid-phase extraction (SupelcoENVI) disk. The sample was passed through the $\mathrm{GFF} / \mathrm{C} 18$ disk under pressure, as needed. Following compound isolation, the GFF/C18-disk was rinsed with 25 percent methanol in reagent water and dried with nitrogen, and the compounds were eluted with methanol. The methanol eluent was evaporated to dryness and reconstituted in a mixture of 5 percent methanol in dichloromethane $(\mathrm{DCM} / \mathrm{MeOH})$. The extract was passed through a 1-gram Florisil SPE column and eluted with the $\mathrm{DCM} / \mathrm{MeOH}$ solution. The eluent was reduced in volume and transferred to a $5-\mathrm{mL}$ reaction vial, then evaporated to dryness. Ketone and alcohol groups on the analytes and IDSs were derivatized to trimethylsilyl or trimethylenol ether analogs to make them stable for analysis by gas chromatography. Derivation was accomplished by addition of 200 microliters $(\mu \mathrm{L})$ of $N$-methyl- $N$-(trimethylsilyl)- trifluoroacetamide (MSTFA) activated with 2(trimethylsilyl)ethanethiol and ammonium iodide $\left(\mathrm{NH}_{4} \mathrm{I}\right)$, then heating the MSFTA solution to $65^{\circ} \mathrm{C}$ for 1 hour. The analytes were separated by gas chromatography and quantified by tandem quadrupole mass spectrometry using an isotope dilution procedure. The procedure allowed for quantitation of 17 natural and synthetic hormones and 2 animal sterols (James Gray, U.S. Geological Survey, written commun., 2010, table 2). The relative percent difference for compounds detected in duplicate samples collected during the sampling period ranged from 1.3 percent to 26 percent (Appendix B, table B-1). Percent recoveries from spiked reagent-water samples ranged from 66 percent to 114 percent (Appendix C, table C-1).

\section{Organic Wastewater Compounds}

Samples were analyzed for OWCs at the USGS NWQL in Denver, Colorado, by capillary-column gas chromatography/mass spectrometry (GC/MS) using methods described in Zaugg and others (2002). The list of target compounds in the analytical schedule for OWCs includes detergent metabolites, fragrances, flavors, pesticides, industrial compounds, disinfectants, PAHs, fire retardants and plasticizers, and plant sterols (table 3).

\section{Streambed-Sediment Samples}

\section{Antibiotics and Ibuprofen}

Antibiotics and ibuprofen in streambed-sediment samples were analyzed at the USGS OGRL in Lawrence, Kansas. The analytical method consisted of accelerated solvent extraction and LC/MS/MS with ESI using MRM. Samples were analyzed in positive-ion mode except for chloramphenicol and ibuprofen, which were analyzed in negative-ion mode. Eleven compounds were used as internal standards and four compounds 
were used as surrogate standards. All of the internal standards except simetone were applied to all samples before extraction. Surrogates were amended to extracts before evaporation of the organic phase of the extraction buffer. Simetone was used as a sample post-processing instrument internal standard to compensate for potential variation in the chromatographic analysis (M. Meyer, U.S. Geological Survey, written commun., April 6, 2009). This analytical method has not received USGS approval. A list of the compounds covered by this analytical technique is provided in table 1 . The relative percent difference for compounds detected in duplicate samples collected during the sampling period ranged from 0 percent to 69 percent (Appendix B, table B-4).

\section{Hormones}

Streambed-sediment samples were analyzed for hormones at the USGS NWQL in Denver, Colorado. Extraction of solid samples by the USGS NWQL uses about 10 grams of material (dry weight), with lesser amounts used for matrices anticipated to have high organic matter or high concentrations of target analytes (for example, biosolids). Samples were stored frozen $\left(-15^{\circ} \mathrm{C}\right)$ if not extracted within about 4 days following receipt. Thawed samples were homogenized prior to sub-sampling for extraction or for separate dry weight determination. Dry weight was obtained by weighing a sample aliquot in a tared aluminum pan after heating at $130^{\circ} \mathrm{C}$ for at least 16 hours. Sample aliquots for extraction were placed in a tared Accelerated Solvent Extraction (ASE; Dionex Corp.) cell and reweighed to determine the wet weight of extracted sample aliquot. Reagent sand was added to the cell, as needed, on the basis of cell and sample size. The sample was fortified with 100 nanograms (ng) of the same 13 deuteriumlabeled IDSs that were used for the hormones in water methods. The sample was extracted by pressure solvent extraction using the ASE instrument with a mixture of water and isopropyl alcohol $(50: 50$, volume/volume $[\mathrm{v} / \mathrm{v}])$ at $120^{\circ} \mathrm{C}$ and water and isopropyl alcohol $(20: 80, \mathrm{v} / \mathrm{v})$ at $200^{\circ} \mathrm{C}$ using three static cycles (40 minutes total) at each temperature at a pressure of 13.8 megaPascals. The resultant ASE extract portions were sequentially passed through an OASIS ${ }^{\circledR} \mathrm{HLB}$ (Waters Corp.) SPE column to isolate the method compounds on the column using the procedure given in Burkhardt and others (2006). The column was dried with nitrogen gas at 2 liters per minute flow of nitrogen for 15 minutes. Method compounds were eluted from the OASIS column and passed through a 2-gram (g) Florisil cleanup column (containing about $2.5 \mathrm{~g}$ of sodium sulfate above the Florisil) by using a $25-\mathrm{mL}$ dichloromethane-methanol $(95: 5 \mathrm{v} / \mathrm{v})$ mixture. The resultant extract was concentrated to 1 to $2 \mathrm{~mL}$ by using nitrogen gas evaporation, and then transferred to a silanized $5-\mathrm{mL}$ reaction vial by using a $1.5-\mathrm{mL}$ rinse with the dichloromethane-methanol (95:5) mixture. The extract was evaporated to dryness using nitrogen gas. The method compounds were derivatized using 500- $\mu \mathrm{L}$ of activated MSTFA derivatization reagent and analyzed by GC/MS as described for the hormones in water method (James Gray, U.S. Geological Survey, written commun., 2010).

The hormone analysis for this study included natural and synthetic hormones and animal sterols. All compounds analyzed are listed in table 2 .

\section{Organic Wastewater Compounds}

Streambed-sediment samples were analyzed for OWCs at the USGS NWQL in Denver, Colorado using methods described by Burkhardt and others, 2006. These compounds include the detergent metabolites, fragrances, flavors, pesticides, industrial compounds, disinfectants, PAHs, fire retardants, and plasticizers (Burkhardt and others, 2006) (table 3).

For analysis of OWCs in streambed sediment, samples were extracted using a pressurized solvent extraction system. The compounds of interest were extracted from interfering matrix components by high-pressure water/isopropyl alcohol extraction. The compounds were isolated using disposable SPE cartridges containing chemically modified polystyrenedivinylbenzene resin. The cartridges were dried with nitrogen gas. Sorbed compounds were eluted with methylene chloride (80 percent)-diethyl ether (20 percent) through a Florisil/ sodium sulfate SPE cartridge, then identified using capillarycolumn GC/MS. Details of the method are provided in Burkhart and others (2006).

\section{Data Analysis}

The reporting level for each compound is listed in tables 1 to 3 . Reporting levels used for pharmaceutical compounds (excluding antibiotics) in water are the method detection limits used by Loper and others (2007). Reporting levels used for antibiotic compounds in water and streambed-sediment are MDLs reported by the ORGL. Reporting levels for hormones and OWCs in water and streambed sediments are the lowest MDLs reported by the NWQL during the sampling period. The data included in this report contained concentrations below the reporting levels listed in tables 1 to 3 and concentrations reported as estimated values. Concentrations less than the reporting level are considered to be less quantitative than concentrations greater than the reporting level. All concentrations reported as estimated were used in the data analysis. Tables present a summary of the data at concentrations greater than and less than the reporting level. All figures indicate if data less than the reporting level are included in the data presentation. Data have been published in Loper and others (2007) and in the USGS Water-Data Reports from 2007 to 2010 (U.S. Geological Survey, 2007-2010). 


\section{Quality Assurance and Quality Control}

The value of chemical measurements depends upon the level of confidence that can be placed in the laboratory results. Quality assurance and quality control are particularly important for this study because concentrations of the compounds under investigation are in the nanogram per liter (water sample) or mid-microgram per kilogram range (streambed-sediment samples). These concentrations are at the lower end of the detection limits for the newly developed laboratory methods.

\section{Quality Control for Field Measurements}

Various controls were used to quality-assure field-meter measurements. Thermistors for field instruments were checked against a National Institute of Standards and Technology certified thermometer one time prior to each sampling season using methods described by Wilde (variously dated). Calibrationacceptance limits were $\pm 0.15^{\circ} \mathrm{C}$. Certified standards and buffers were used to calibrate multi-parameter meters on the day of sampling using methods described in Wilde (variously dated). All field meter calibration data were recorded in the respective meter log book and on the site field data sheet.

\section{Quality Control for Streamwater and Streambed- Sediment Samples}

\section{Blanks}

The primary purpose of blanks is to determine the likelihood that samples were contaminated by sampling and processing procedures. Secondarily, blanks are used to trace sources of contamination. Because of the ease with which extremely low levels of the analytes measured in this study can be contaminated, frequent blank samples were needed to achieve the study's data-quality objectives.

An equipment-blank or field-blank sample was collected by pouring certified organic-free water through field equipment either in a USGS Pennsylvania Water Science Center (PA-WSC) laboratory or at a field site and processing the sample through a filter assembly that had been cleaned according to USGS protocols (Wilde, 2004) after having been used previously for environmental sample collection. Blanks made up approximately 5 percent of all samples submitted for analyses. Six equipment blanks were collected in the PA-WSC laboratory in 2006, three for pharmaceutical compounds (excluding antibiotics) in water and three for antibiotic compounds in water. From 2006 through 2009, 77 field-blank samples were collected: 31 samples for pharmaceutical compounds (excluding antibiotics), 32 samples for antibiotics compounds, 11 samples for hormones, and 3 samples for OWCs. No blanks samples were submitted for sediment analyses.

Detection of contaminants of emerging concern in blank samples was rare. There were seven total detections at concentrations greater than the reporting level in the 79 blank samples collected from 2006 to 2009. One measured concentration was reported for an equipment blank, and the remaining six detections were reported for six separate field blanks.

One pharmaceutical compound, salbutamol, was detected in one blank sample at a concentration of $11 \mathrm{ng} / \mathrm{L}$ (table 10). Salbutamol was detected in four environmental samples at a concentration range of 9-30 ng/L. For the antibiotics, tylosin was detected in one equipment blank submitted to the OGRL in 2006 at a concentration of $6 \mathrm{ng} / \mathrm{L}$ (table 10). OGRL statistics for 2006 show that 15 percent of all the laboratory reagent blanks (LRBs) had detections of tylosin, and the average concentration of the detections was $7 \mathrm{ng} / \mathrm{L}$. LRBs are used to monitor for contamination during the extraction and analysis process. These findings indicate that the contamination was introduced from the equipment or during the analysis.

Table 10. Compounds detected in equipment and field-blank samples collected from 2006 to 2009.

[ng/L, nanograms per liter]

\begin{tabular}{lccc}
\hline \multicolumn{1}{c}{ Compound } & $\begin{array}{c}\text { Number of } \\
\text { analyses }\end{array}$ & $\begin{array}{c}\text { Number of detections } \\
\text { at concentrations } \\
\text { greater than } \\
\text { reporting level }\end{array}$ & $\begin{array}{c}\text { Concentration } \\
\text { (ng/L) }\end{array}$ \\
\hline \multicolumn{4}{c}{ Prescription pharmaceutical } \\
\hline Salbutamol & 33 & 1 \\
\hline \multicolumn{4}{c}{ Macrolide antibiotics and metabolites } \\
\hline Erythromycin- $\mathrm{H}_{2} \mathrm{O}$ & 32 & 1 & 8 \\
Tylosin & 32 & 1 & 6 \\
\hline \multicolumn{4}{c}{ Natural androgen } \\
\hline Testosterone & 11 & 1 \\
\hline Bisphenol A & Organic wastewater compound \\
\hline
\end{tabular}


Erythromycin- $\mathrm{H}_{2} \mathrm{O}$, an antibiotic metabolite, was detected at the reporting level $(8 \mathrm{ng} / \mathrm{L})$ in one field blank in 2007 . The hormone compound testosterone was found in one blank sample at a concentration of $1 \mathrm{ng} / \mathrm{L}$ (reporting limit of $0.8 \mathrm{ng} / \mathrm{L}$ ), and there were three detections of bisphenol $\mathrm{A}$ in blank samples at concentrations of $396 \mathrm{ng} / \mathrm{L}, 478 \mathrm{ng} / \mathrm{L}$, and $443 \mathrm{ng} / \mathrm{L}$ (reporting level of $100 \mathrm{ng} / \mathrm{L}$ ). The LRL for bisphenol A was raised to $200 \mathrm{ng} / \mathrm{L}$ in 2010. Because of the blank results and increased MRL, results for bisphenol A will not be presented in this report. Overall, the blank data indicate environmentalsample results for all water compounds were not affected by contamination introduced from cleaning procedures, sampling procedures, or analytical processes.

\section{Duplicates}

Field duplicate samples were collected during the study to evaluate variability (reproducibility) in the analytical results introduced during collection, processing, and laboratory analysis. Field duplicates are separate samples collected at the same time, shipped, and stored under identical conditions. Duplicate streamwater or streambed-sediment samples are either split from the primary environmental sample or collected immediately after primary environmental samples; these duplicates are referred to as split duplicates and sequential duplicates, respectively. Variability in sequential-duplicate results also can reflect temporal changes in environmental conditions because the sequential duplicate is collected as a separate sample after the primary sample.

Duplicate samples for analysis of pharmaceuticals in streamwater were collected during the 4 years of study (2006-09). Duplicates for hormones and OWCs in water and antibiotics, hormones, and OWCs in streambed sediment were collected from 2007 to 2009 when the scope of the study was expanded to include additional compounds in water and streambed sediment. Duplicates made up about 3.7 percent of all samples submitted for analysis. Forty-nine samples were collected as duplicates of primary environmental samples. Duplicates for 34 water samples, including 15 samples to be analyzed for antibiotics, 13 samples for other pharmaceuticals, 3 samples for hormones, and 3 samples for OWCs, and duplicates for 15 streambed-sediment samples included 5 samples to be analyzed for antibiotics, 6 samples for hormones, and 4 samples for OWCs. Two of the duplicates for antibiotics in water and one duplicate for hormones in sediment were split samples divided at either the OGRL or the NWQL. The 6 duplicate samples from sites near drinking-water intakes were collected as field-split duplicates; the remaining 40 duplicate samples were collected as field-sequential duplicates.

Variability was evaluated by calculating relative percent difference $(R P D)$ using constituent concentrations from the primary environmental sample and the duplicate sample (henceforth called a duplicate pair) but only if the results from the duplicate pair were greater than the reporting level. $R P D$ calculations were not made when constituent concentrations in both samples in the duplicate pair were less than the reporting level or if one or both samples in the duplicate pair had estimated concentrations. $R P D$ was calculated according to the following equation:

$$
R P D=((|E-D|) /((E+D) / 2)) \times 100
$$

where

$$
E \quad \text { is the concentration of the environmental (or }
$$
parent) sample

and

$$
D \quad \text { is the concentration of the duplicate sample. }
$$

In general, variability was 30 percent or less for most contaminants of emerging concern analyzed in duplicate water samples. Exceptions to this generalization are diphenhydramine, diltiazem, tylosin, and sulfadiazine. Variability was much greater for compounds analyzed in duplicate streambedsediment samples. Two antibiotics, 5 hormones, 2 animal sterols, and 18 OWCs had median RPDs greater than 30 percent (table 11). Results from duplicate samples collected in 2006 are presented in a report by Loper and others (2007). Summary tables for duplicate samples, by compound, are presented in Appendix B (tables B-1-B-4).

\section{Laboratory-Matrix Spikes}

A laboratory-matrix spike (LMS) (or laboratory-spiked environmental sample) is prepared when a chemist adds known quantities of method analytes to an environmental sample. The LMS is analyzed exactly like an un-spiked sample.

The purpose of a LMS is to determine whether the environmental water or sediment matrix creates interferences in analytical recoveries of compounds that may cause positive or negative bias in reported data (Furlong and others, 2008) and to determine the likelihood of false negatives. False-negative results would occur if a spiked compound was not detected in the spiked sample.

If a spike is added to an environmental sample that already contains concentrations of the same compound, the evaluation of spike recovery takes into consideration the measured concentration of the compound in the un-spiked sample. In this case, the concentration in the environmental sample is subtracted from the value of the spiked sample before the measured value of the spike is compared to the expected value of the spike (eq. 2). If there is no compound reported in the environmental sample associated with the spiked sample, no adjustments are needed.

$$
\text { Percent recovery }=\left(C_{\text {spiked }}-C_{\text {unspiked }}\right) / C_{\text {expected or theoretical }}
$$

Spiked environmental results reflect the analytical recovery efficiencies and matrix effects of the environmental water. Very high or low compound recoveries affect the ability of the instrument to quantify the concentrations of the compounds but do not affect the capability of the analytical method to detect the compound. 
Nine samples, about 1 percent of all samples analyzed for the study, were submitted as LMSs. Three samples were submitted for analysis of antibiotics in water, two samples for other pharmaceuticals in water, one sample each for hormones and OWCs in water, and one sample for OWCs in streambed sediment.

Results for LMSs were evaluated (1) to determine whether false-negatives were present (negative-detection bias) and (2) to determine whether matrix interferences were present that would cause positive or negative bias in reported results for the primary environmental sample associated with the spike. Therefore, for the purposes of this report, discussion and presentation of LMS recoveries will be limited to compounds that were detected in associated un-spiked environmental samples (Appendix C, tables C-2 to C-9).
In general, mean recoveries for most compounds in streamwater samples were 70 to 120 percent. Recoveries in water ranged from 18 percent (lincomycin) to 237 percent (total chlorotetracycline). Mean recoveries for OWCs in streambed-sediment samples were variable with a typical mean recovery in the 40 to 200 percent range. Recoveries for most of the OWCs were lower than 80 percent and many were lower than 50 percent. Recoveries in streambed sediment ranged from 81 percent (negative recovery) (indole) to 1,669 percent (beta-sitosterol) (table 12). False negatives were reported for 10 compounds in streambed-sediment LMS samples. Negative recoveries were reported for four compounds in spiked streambed-sediment samples.

Table 11. Statistical summary of relative percent differences for contaminants of emerging concern in duplicate samples of streamwater and streambed sediment collected in Pennsylvania, 2007-09.

[NWQL, U.S. Geological Survey National Water Quality Laboratory in Denver, Colorado: OGRL, Organic Geochemistry Research Laboratory in Lawrence, Kansas; RPD, relative percent difference]

\begin{tabular}{lcccc}
\hline $\begin{array}{c}\text { Laboratory and } \\
\text { analytical method }\end{array}$ & $\begin{array}{c}\text { Number of duplicate } \\
\text { pairs where both } \\
\text { results were above } \\
\text { the reporting level }\end{array}$ & $\begin{array}{c}\text { Minimum RPD, } \\
\text { in percent }\end{array}$ & $\begin{array}{c}\text { Maximum RPD, } \\
\text { in percent }\end{array}$ & $\begin{array}{c}\text { Median RPD, } \\
\text { in percent }\end{array}$ \\
\hline \multicolumn{5}{c}{ Streamwater samples } \\
\hline NWQL pharmaceutical ${ }^{1}$ & 21 & 0 & 40 & 18 \\
NWQL hormones & 7 & 1.3 & 26 & 10 \\
NWQL OWCs & 10 & 0 & 11 & 5 \\
ORGL antibiotics ${ }^{2}$ & 44 & 0 & 140 & 18 \\
\hline \multicolumn{5}{c}{ Streambed-sediment samples } \\
\hline NWQL hormones & 15 & 5 & 159 & 32 \\
NWQL OWCs & 49 & 0 & 69 & 27 \\
ORGL antibiotics $^{2}$ & 13 & 0 &
\end{tabular}

Table 12. Statistical summary of recoveries of laboratory-matrix spike samples for selected analytical methods used in this study.

[ NWQL, U.S. Geological Survey National Water Quality Laboratory in Denver, Colorado: OGRL, Organic Geochemistry Research Laboratory in Lawrence, Kansas; OWCs, organic wastewater compounds]

\begin{tabular}{|c|c|c|c|c|}
\hline \multirow{2}{*}{$\begin{array}{l}\text { Laboratory and } \\
\text { analytical method }\end{array}$} & \multirow{2}{*}{$\begin{array}{c}\text { Number of } \\
\text { laboratory-matrix } \\
\text { spike compounds } \\
\text { analyzed }\end{array}$} & Minimum & Maximum & Mean \\
\hline & & \multicolumn{3}{|c|}{ Recovery, in percent } \\
\hline \multicolumn{5}{|c|}{ Streamwater samples } \\
\hline NWQL pharmaceutical $^{1}$ & 12 & 38 & 116 & 81 \\
\hline NWQL hormones & 19 & 42 & 127 & 90 \\
\hline NWQL OWCs & 56 & 31 & 123 & 99 \\
\hline ORGL antibiotics $^{2}$ & 26 & 18 & 237 & 102 \\
\hline \multicolumn{5}{|c|}{ Streambed-sediment samples } \\
\hline NWQL OWCs & 50 & $(-81)$ & 1,669 & 123 \\
\hline
\end{tabular}




\section{Pharmaceuticals, Hormones, and Organic Wastewater Compounds in Pennsylvania Waters}

The targeted contaminants of emerging concern in water samples collected for these studies occurred in very low (nanograms per liter) concentrations. Many of the compounds were not detected in most of the streamwater or streambedsediment samples. Others were not detected in any samples at all.

\section{Compounds in Groundwater Used to Supply Livestock}

Six wells located in agricultural areas underlain by limestone geological formations were selected for study (table 5). These wells were sampled four times (approximately quarterly) during 2006. Samples were analyzed for a suite of 44 pharmaceutical compounds (table 1) in filtered water. Complete analytical results of these samples are presented in a report by Loper and others (2007).

Four pharmaceutical compounds were detected in the 24 samples collected from 6 wells located in agricultural areas (table 13). Cotinine (nicotine metabolite) was detected once at a concentration of $24 \mathrm{ng} / \mathrm{L}$ (greater than reporting level) in one sample from a Lebanon County well W5 (LB1249), and diphenhydramine was detected once at a concentration of $3 \mathrm{ng} / \mathrm{L}$ (less than reporting level) in one sample from a Huntingdon County well W4 (HU 426). Tylosin was detected in one Lebanon County well W3 (LB 1248) and in one Lancaster County well W5 (LN 2114), and sulfamethoxazole was detected in one of the Lebanon County wells W5 (LB 1249). The largest concentration of any pharmaceutical compound measured in the groundwater samples was for cotinine, with a concentration of $24 \mathrm{ng} / \mathrm{L}$ in a water sample from a Lebanon County well W5 (LB 1249) (table 13). Tylosin is a veterinary antibiotic, and its presence in a groundwater sample may be related to the agricultural land use at the sampling site. Cotinine and sulfamethoxazole are for human use and are not related to agricultural land use at the sampling site. Overall the detection of pharmaceutical compounds in groundwater samples in agricultural areas was rare, and the detections that did occur were at very low concentrations (less than $24 \mathrm{ng} / \mathrm{L}$ ).

\section{Compounds in Streamwaters Upstream and Downstream from Animal-Feeding Operations}

Animal-feeding operations are present in the watersheds of six streams in south-central Pennsylvania that were selected for sampling (table 5). Four times (approximately quarterly) during 2006, streamwater samples were collected from the six streams at sites upstream and downstream from the AFOs. Samples were collected during base-flow conditions.
The filtered water samples were analyzed for a suite of 44 pharmaceutical compounds (table 1). Complete analytical results of these samples are presented in a report by Loper and others (2007).

Nine different pharmaceutical compounds (including 4 antibiotics) were detected in the 48 samples collected from six streams at sites upstream and downstream from the AFOs (table 13). Three compounds were detected at concentrations greater than their reporting levels, including acetaminophen (analgesic), caffeine (stimulant), and carbamazepine (anticonvulsant). Two compounds, cotinine (nicotine metabolite) and diphenhydramine (antihistamine), were detected at concentrations less than the reporting levels (fig. 6). The antibiotic compounds detected were tylosin, sulfadimethoxine, sulfamethoxazole, and oxytetracycline (table 13). The greatest concentration for a pharmaceutical compound was $157 \mathrm{ng} / \mathrm{L}$ for the antibiotic sulfamethoxazole in a sample from the upstream site on Snitz Creek (A7, 01574050).

In general, few pharmaceutical compounds were detected in streamwater samples collected upstream and downstream from AFOs. Only 9 of the 44 compounds analyzed were detected at least once in the 48 samples analyzed for a total detection frequency of 2 percent. The detected compounds that are related to agricultural use are the antibiotics tylosin, sulfadimethoxine, and oxytetracycline. The presence of these compounds may be related to AFOs, but tylosin and sulfadimethoxine were also detected in samples collected on the same day upstream and downstream from AFOs. Non-veterinary compounds also were detected in samples collected upstream and downstream from the AFOs. This finding is an indication that these compounds are not directly related to the specific AFOs but are generally present in groundwater discharge in the entire watershed. Most of these sites are located in small agricultural-dominated drainage areas with a few single-family residential homes that have on-lot septic systems for wastewater disposal. General agricultural land use and the on-lot septic systems may be a source of contaminants upstream of the AFO locations, especially during low-flow conditions (Senior and Cinotto, 2007).

\section{Compounds in Streamwater and Streambed Sediments Upstream and Downstream from Wastewater Discharges}

In 2006, water samples from five streams were collected at sites upstream and downstream from municipal wastewatereffluent-discharge sites (table 5). Samples were collected four times (approximately quarterly) from March to September at base-flow conditions and analyzed for pharmaceutical compounds. Complete analytical results of these samples are presented in a report by Loper and others (2007).

In 2007, 2008, and 2009, sampling continued at the sites downstream from the wastewater-effluent-discharge sites; four additional sites were added to the sampling, including sites on three streams receiving wastewater effluents, Quittapahilla 
Table 13. Pharmaceutical compounds detected in quarterly samples collected from 6 wells in agricultural areas and 12 stream sites located upstream and downstream from animal-feeding operations in Pennsylvania.

[ng/L, nanograms per liter]

\begin{tabular}{|c|c|c|c|c|}
\hline Compound & $\begin{array}{c}\text { Number of } \\
\text { analyses }\end{array}$ & $\begin{array}{l}\text { Number of detections } \\
\text { at concentrations } \\
\text { greater than } \\
\text { reporting level }\end{array}$ & $\begin{array}{l}\text { Number of detections } \\
\text { at concentrations } \\
\text { less than } \\
\text { reporting level }\end{array}$ & $\begin{array}{l}\text { Concentration } \\
\text { range } \\
\text { (ng/L) }\end{array}$ \\
\hline \multicolumn{5}{|c|}{ Wells in agricultural areas } \\
\hline \multicolumn{5}{|c|}{ Nonprescription pharmaceuticals and metabolites } \\
\hline Cotinine $^{1}$ & 24 & 1 & 0 & 24 \\
\hline Diphenhydramine & 24 & 0 & 1 & 3 \\
\hline \multicolumn{5}{|c|}{ Macrolide antibiotics } \\
\hline Tylosin & 24 & 2 & 0 & $12-17$ \\
\hline \multicolumn{5}{|c|}{ Sulfonamide antibiotics } \\
\hline Sulfamethoxazole & 24 & 1 & 0 & 6 \\
\hline \multicolumn{5}{|c|}{ Stream sites upstream from animal-feeding operations } \\
\hline \multicolumn{5}{|c|}{ Nonprescription pharmaceuticals and metabolites } \\
\hline Caffeine $^{1}$ & 24 & 2 & 0 & $16-19$ \\
\hline Diphenhydramine & 24 & 0 & 1 & 10 \\
\hline \multicolumn{5}{|c|}{ Prescription pharmaceuticals } \\
\hline Carbamazepine & 24 & 2 & 2 & $5-25$ \\
\hline \multicolumn{5}{|c|}{ Macrolide antibiotics and metabolites } \\
\hline Tylosin & 24 & 1 & 0 & 17 \\
\hline \multicolumn{5}{|c|}{ Sulfonamide antibiotics } \\
\hline Sulfadimethoxine & 24 & 1 & 0 & 26 \\
\hline Sulfamethoxazole & 24 & 2 & 0 & $19-157$ \\
\hline \multicolumn{5}{|c|}{ Stream sites downstream from animal-feeding operations } \\
\hline \multicolumn{5}{|c|}{ Nonprescription pharmaceuticals and metabolites } \\
\hline Acetaminophen & 24 & 1 & 3 & $3-18$ \\
\hline Caffeine $^{1}$ & 24 & 4 & 0 & $18-53$ \\
\hline Cotinine $^{1}$ & 24 & 0 & 2 & 7 \\
\hline \multicolumn{5}{|c|}{ Prescription pharmaceuticals } \\
\hline Carbamazepine & 24 & 0 & 2 & 5 \\
\hline \multicolumn{5}{|c|}{ Macrolide antibiotics and metabolites } \\
\hline Tylosin & 24 & 1 & 1 & $7-27$ \\
\hline \multicolumn{5}{|c|}{ Sulfonamide antibiotics } \\
\hline Sulfadimethoxine & 24 & 3 & 0 & $5-26$ \\
\hline Sulfamethoxazole & 24 & 1 & 0 & 19 \\
\hline \multicolumn{5}{|c|}{ Tetracycline antibiotics and metabolites } \\
\hline Oxytetracycline & 24 & 1 & 0 & 19 \\
\hline
\end{tabular}

${ }^{1}$ Compounds are not strictly pharmaceuticals but are included in the pharmaceutical analysis because they are associated with human use. 


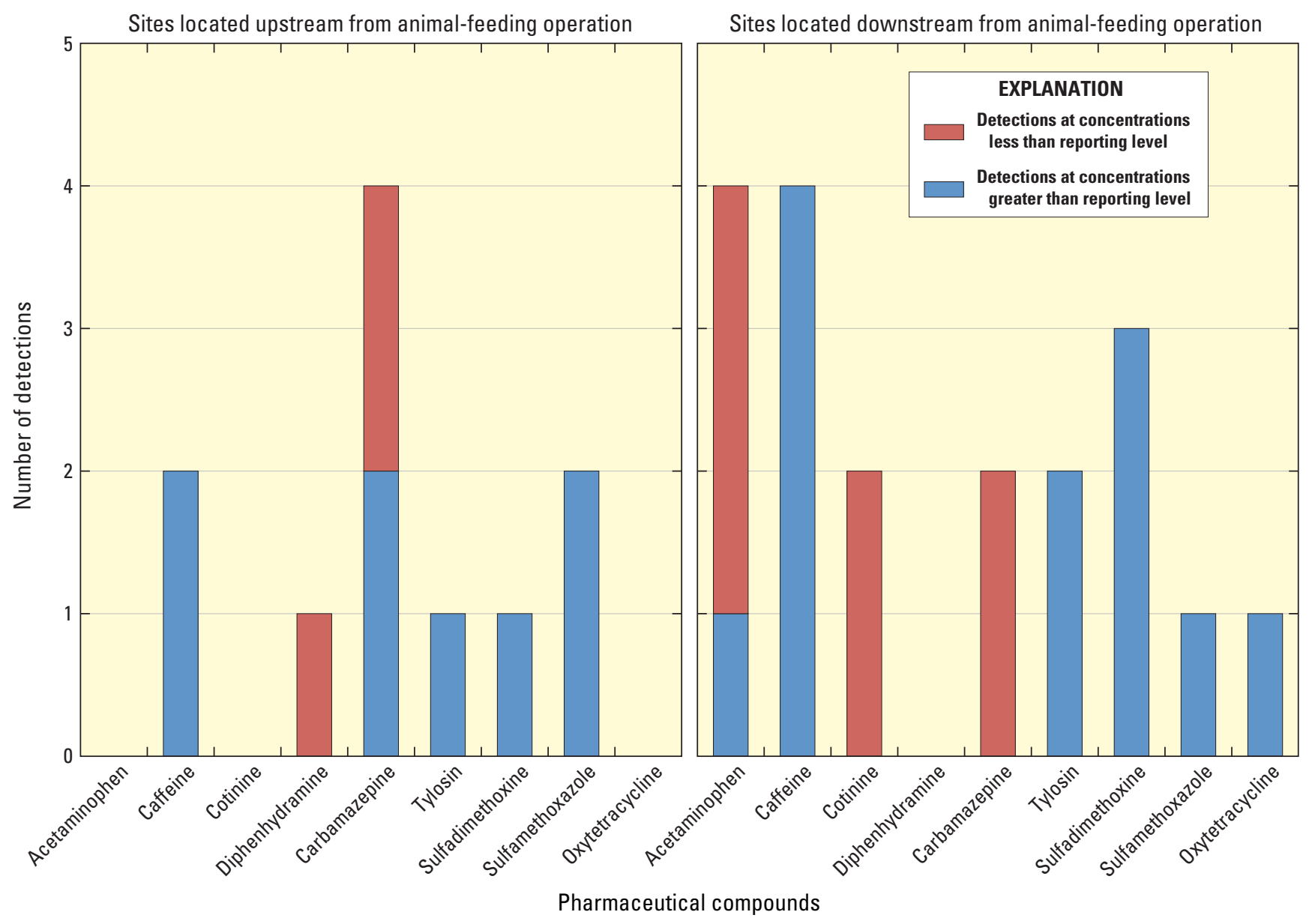

Figure 6. Pharmaceutical compounds detected in 24 streamwater samples collected from paired stream sites located upstream and downstream from five animal-feeding operations in Pennsylvania, 2006. 
Creek, East Branch Antietam Creek, and Rock Creek and on one stream that received no municipal wastewater effluents (Clark Creek). Conoy Creek was omitted from the streams sampled (see footnote on table 5). During 2007-09, sampling was done once each year during summer low-flow periods. Samples of streambed sediments were collected and analyzed, in addition to water samples. Laboratory analyses were expanded to include hormones (table 2) and OWCs (table 3) in water, in addition to pharmaceutical compounds. Laboratory analyses of the streambed-sediment samples included antibiotics (table 1), hormones (table 2), and OWCs (table 3).

\section{Sampling Upstream and Downstream from Wastewater-Effluent-Discharge Sites}

The sampling design used in 2006 allowed for a comparison of contaminant of emerging concern occurrence upstream and downstream from wastewater-treatment plants. Eleven different pharmaceutical compounds were detected (12 total detections) in the 20 samples collected from the five sites located upstream from a wastewater-effluent-discharge site (table 14). Acetaminophen, caffeine, para-xanthine, carbamazepine, erythromycin $\mathrm{H}_{2} \mathrm{O}$, roxithromycin, ofloxacin, sulfamethoxazole, oxytetracycline, and trimethoprim were detected at concentrations greater than the reporting level, and cotinine was detected at a concentration less than the reporting level (table 14). All eleven compounds also were detected in the samples collected at the corresponding sites located downstream from the wastewater-effluent-discharge site. Twenty-three pharmaceutical compounds were detected (166 total detections) in samples from the five sites located downstream from a wastewater-effluent-discharge site (table 14). All 23 compounds were detected at least once at concentrations greater than the reporting level. A greater number of compounds were detected and at a greater detection frequency at sites downstream from wastewater-effluent discharges than at sites upstream from wastewater-effluent discharges (fig. 7 and fig. 8). Concentrations of individual constituents also were greater at the five sites located downstream from wastewatereffluent discharges than at the five sites located upstream from wastewater-effluent discharges. Carbamazepine was detected once in the four samples collected at Killinger Creek (T7, 01573151) upstream from the wastewater-effluent-discharge site at a concentration of $9 \mathrm{ng} / \mathrm{L}$ but was detected in all four samples collected at the site $(\mathrm{T} 8,01573153)$ downstream from the wastewater-effluent discharge at an average concentration of $138 \mathrm{ng} / \mathrm{L}$ (fig. 9). Similarly, diltiazem and diphenhydramine were not detected in the four samples collected from Middle Spring Creek (T3, 015693155) upstream from the wastewater-effluent discharge but were detected in all four samples collected at the site (T4, 015693158) downstream from the wastewater-effluent discharge at average concentrations of $36 \mathrm{ng} / \mathrm{L}$ and $32 \mathrm{ng} / \mathrm{L}$, respectively. Sulfamethoxazole and ofloxacin were detected once each at concentrations of $67 \mathrm{ng} / \mathrm{L}$ and $6 \mathrm{ng} / \mathrm{L}$, respectively, in the four samples collected at Lititz
Run (T12, 01576420) upstream from the wastewater-effluent discharge. Sulfamethoxazole and ofloxacin were also detected in all four samples collected at the site (T13, 01576422) downstream from the wastewater-effluent discharge at average concentrations of $126 \mathrm{ng} / \mathrm{L}$ and $46 \mathrm{ng} /$, respectively (fig. 10). The increased number of detections and higher concentrations detected downstream from the wastewater-effluent discharges are indications that, although some compounds are present upstream from the wastewater-effluent discharge, the effluent is a source of pharmaceutical compounds.

No pharmaceutical compounds were detected in samples from Spring Creek site (T1, 01470857) and Middle Spring Creek site (T3, 015693155) upstream from the wastewatereffluent discharges, and roxithromycin was detected only once in a sample from the Mountain Creek upstream site (T5, 01571193). This finding is an indication that these streams receive little or no input from agriculture or septic sources. These sites are in watersheds with greater than 45 percent forested land use. Six compounds were detected in samples from the Killinger Creek upstream site, and five compounds were detected in samples from Lititz Run upstream from the wastewater-effluent discharge. Two sites on Conoy Creek were originally sampled as part of the paired upstream-downstream wastewater-effluent sampling until it was discovered that the effluent from the water-treatment plant was piped directly to the Susquehanna River and not discharged directly into Conoy Creek. Acetaminophen, caffeine, and cotinine were detected in more than 50 percent of the samples from the two Conoy Creek sites. The most likely source of the contaminants for the sites located upstream from the wastewater-effluent discharge on Killinger Creek, Lititz Run, and on both Conoy Creek sites is on-lot septic systems (Carrara and others, 2008) or agricultural land use. These three sites are in watersheds with greater than 50 percent agricultural land use.

Although more compounds were detected at the five sites downstream from wastewater-effluent-discharge sites and in greater concentrations, there were differences in the detection patterns and concentrations among the five streams. Of the five sites located downstream from wastewater discharges, the Killinger Creek site (T8, 01573153) had the most compounds detected (19) and the highest number of total detections (52). The maximum concentration for 17 of the 23 compounds detected downstream from a wastewater-effluent-discharge site was at the Killinger Creek site (T8, 01573153). Factors such as wastewater-treatment-plant design and efficiency and dilution in the receiving stream can be factors in the number of compounds detected and the concentrations. Killinger Creek is a small stream (drainage area of less than $14 \mathrm{mi}^{2}$ ). Streamflow measurements made at the upstream and downstream sampling sites on Killinger Creek indicate that the average streamflow at the downstream site was 49 percent higher than that at the upstream site (table 15). Although the actual flow from the wastewater-treatment plant at the time of sampling is not known, most of the 49 percent difference between the two sampling sites is likely due to the wastewatereffluent discharge. The Palmyra wastewater-treatment plant, 
Table 14. Pharmaceutical compounds detected in streamwater samples collected from paired stream sites located upstream and downstream from five municipal wastewater-effluent-discharge sites in Pennsylvania, 2006.

[ng/L, nanograms per liter]

\begin{tabular}{|c|c|c|c|c|c|c|c|}
\hline \multirow[b]{2}{*}{ Compound } & \multirow[b]{2}{*}{$\begin{array}{l}\text { Number of } \\
\text { analyses }\end{array}$} & \multicolumn{3}{|c|}{$\begin{array}{l}\text { Stream sites upstream from } \\
\text { wastewater-effluent-discharge sites }\end{array}$} & \multicolumn{3}{|c|}{$\begin{array}{l}\text { Stream sites downstream from } \\
\text { wastewater-effluent-discharge sites }\end{array}$} \\
\hline & & $\begin{array}{l}\text { Number of } \\
\text { detections at } \\
\text { concentrations } \\
\text { greater than } \\
\text { reporting level }\end{array}$ & $\begin{array}{l}\text { Number of } \\
\text { detections at } \\
\text { concentrations } \\
\text { less than } \\
\text { reporting level }\end{array}$ & $\begin{array}{l}\text { Concentration } \\
\text { range } \\
\text { (ng/L) }\end{array}$ & $\begin{array}{l}\text { Number of } \\
\text { detections at } \\
\text { concentrations } \\
\text { greater than } \\
\text { reporting level }\end{array}$ & $\begin{array}{c}\text { Number of } \\
\text { detections at } \\
\text { concentrations } \\
\text { less than } \\
\text { reporting level }\end{array}$ & $\begin{array}{l}\text { Concentration } \\
\text { range } \\
\text { (ng/L) }\end{array}$ \\
\hline Caffeine $^{1}$ & 20 & 1 & 0 & 65 & 7 & 0 & $15-4,750$ \\
\hline Ibuprofen & 20 & 0 & -- & -- & 1 & 0 & 277 \\
\hline Para-xanthine $e^{1,2,3}$ & 20 & 1 & 0 & 20 & 1 & 0 & 853 \\
\hline Codeine & 20 & 0 & -- & -- & 6 & 3 & $5-156$ \\
\hline Carbamazepine & 20 & 1 & 0 & 9 & 15 & 1 & $8-276$ \\
\hline Dehydronifedipine & 20 & 0 & -- & -- & 2 & 2 & $5-15$ \\
\hline Diltiazem & 20 & 0 & -- & -- & 9 & 1 & $5-79$ \\
\hline Salbutamol & 20 & 0 & -- & -- & 2 & 2 & $4-12$ \\
\hline Warfarin & 20 & 0 & -- & -- & 1 & 0 & 30 \\
\hline \multicolumn{8}{|c|}{ Macrolide antibiotics and metabolites } \\
\hline Azithromycin & 20 & 0 & -- & -- & 11 & 0 & $21-1,650$ \\
\hline Erythromycin & 20 & 0 & -- & -- & 5 & 0 & 8- 16 \\
\hline Erythromycin- $\mathrm{H}_{2} \mathrm{O}^{2}$ & 20 & 1 & 0 & 11 & 11 & 0 & $8-168$ \\
\hline Sulfadiazine & 20 & 0 & -- & -- & 1 & 0 & 121 \\
\hline Sulfamethoxazole & 20 & 2 & 0 & $13-67$ & 16 & 0 & $23-1,340$ \\
\hline \multicolumn{8}{|c|}{ Tetracycline antibiotics and metabolites } \\
\hline Oxytetracycline & 20 & 1 & 0 & 38 & 1 & 0 & 15 \\
\hline \multicolumn{8}{|c|}{ Other antibiotics } \\
\hline Trimethoprim & 20 & 1 & 0 & 15 & 16 & 0 & $9-256$ \\
\hline
\end{tabular}

${ }^{1}$ Compounds are not strictly pharmaceuticals but are included in the pharmaceutical analysis because they are associated with human use.

${ }^{2}$ Metabolite breakdown product.

${ }^{3}$ Para-xanthine also know as 1,7 dimethylxanthine. 


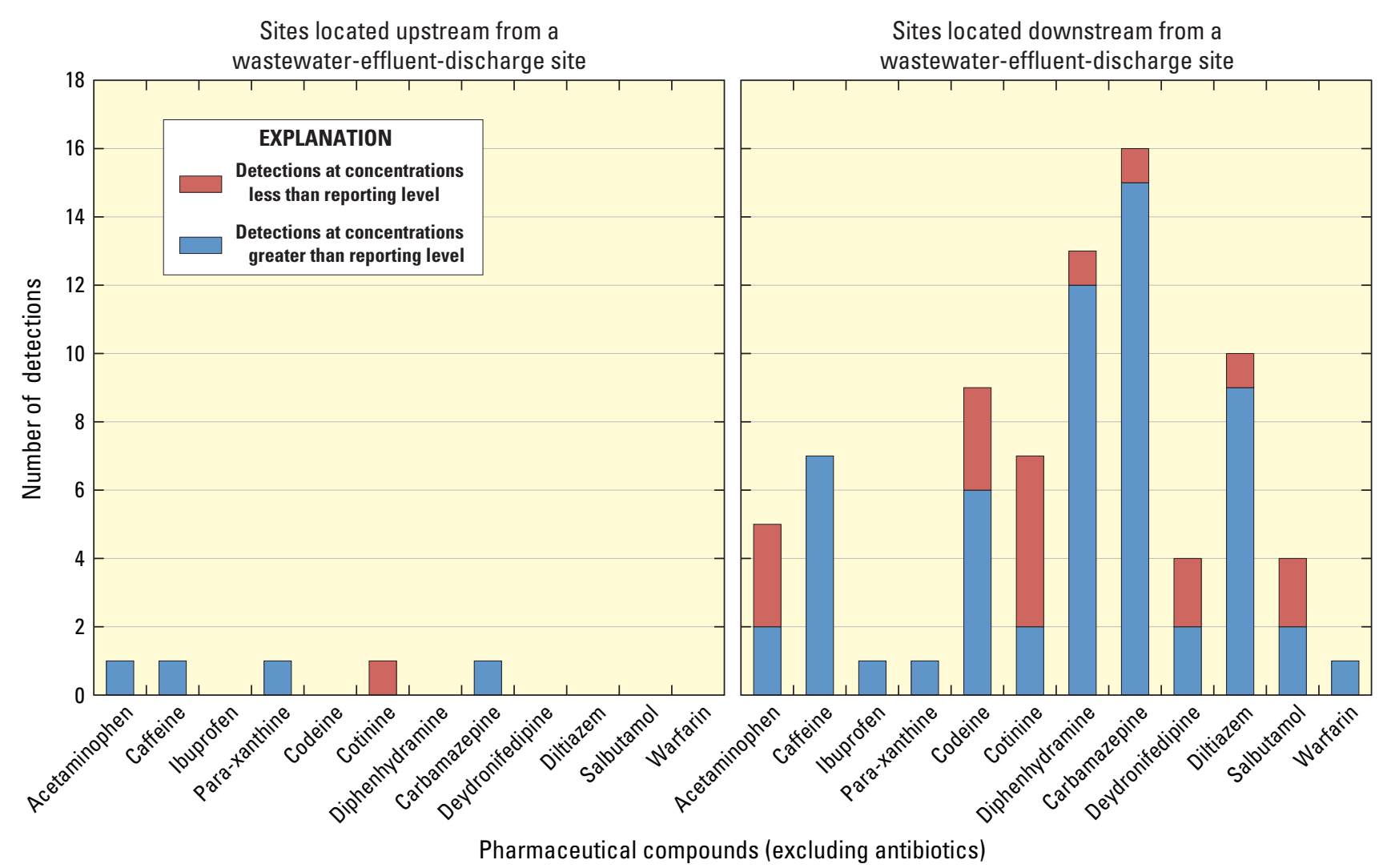

Figure 7. Number of detections of pharmaceutical compounds, excluding antibiotics, in 20 streamwater samples collected from paired stream sites located upstream and downstream from five municipal wastewater-effluent-discharge-sites in Pennsylvania, 2006. 


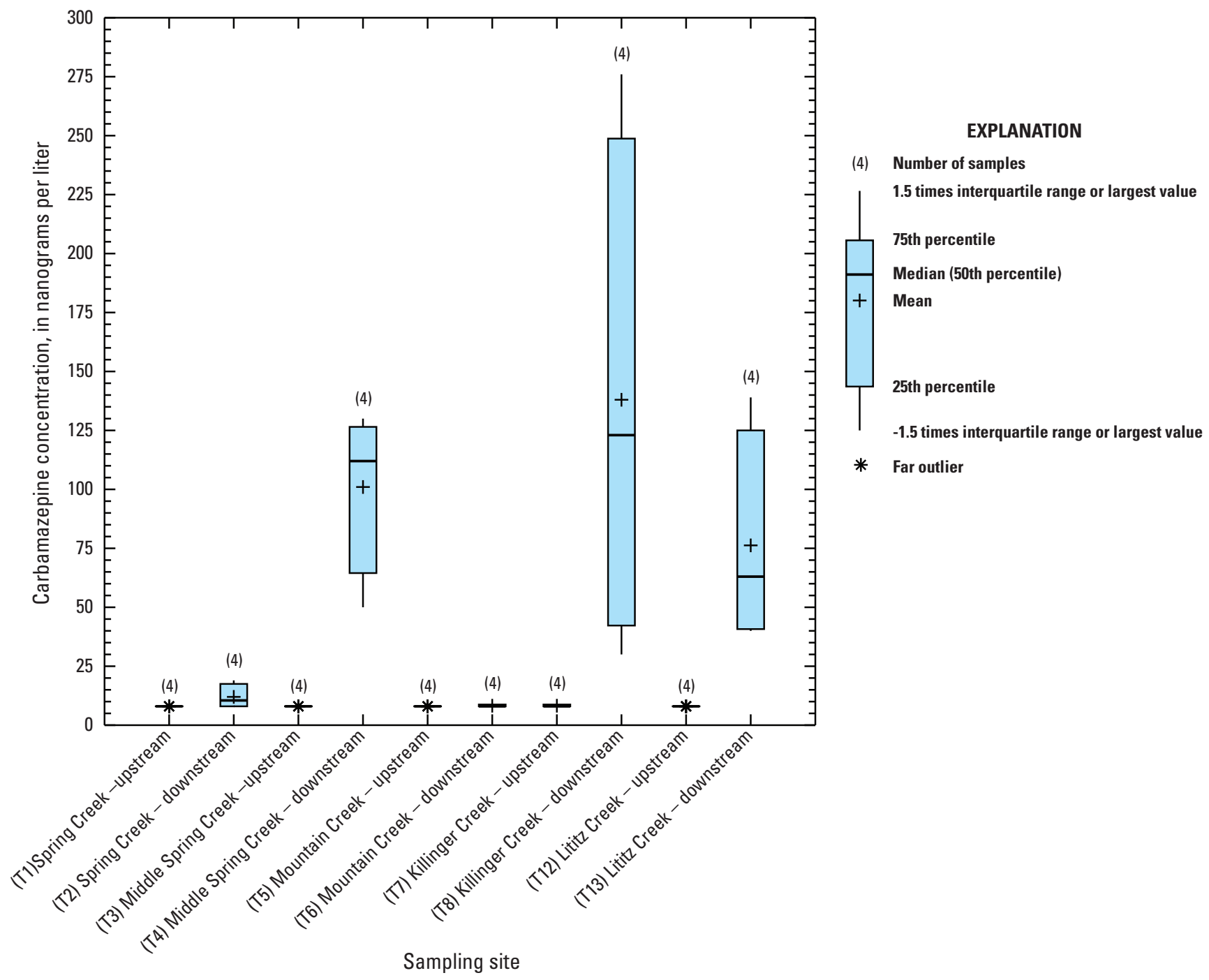

Figure 8. Number of detections of antibiotic compounds at concentrations greater than the reporting level in 20 streamwater samples collected from paired stream sites located upstream and downstream from five municipal wastewater-effluent-discharge sites in Pennsylvania, 2006. 


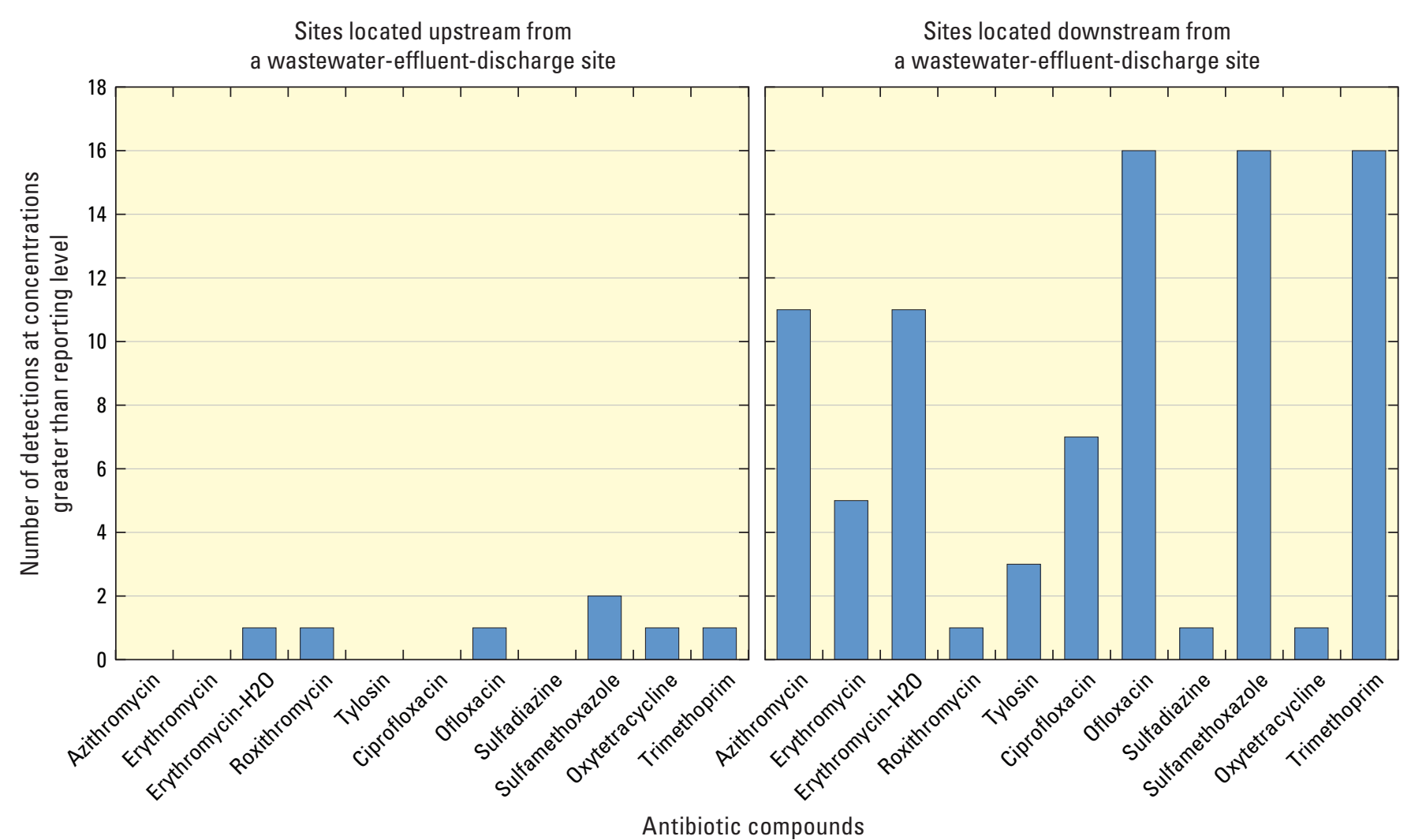

Figure 9. Carbamazepine concentrations in streamwater samples collected from paired stream sites located upstream and downstream from five municipal wastewater-effluent-discharge sites in Pennsylvania, 2006. 


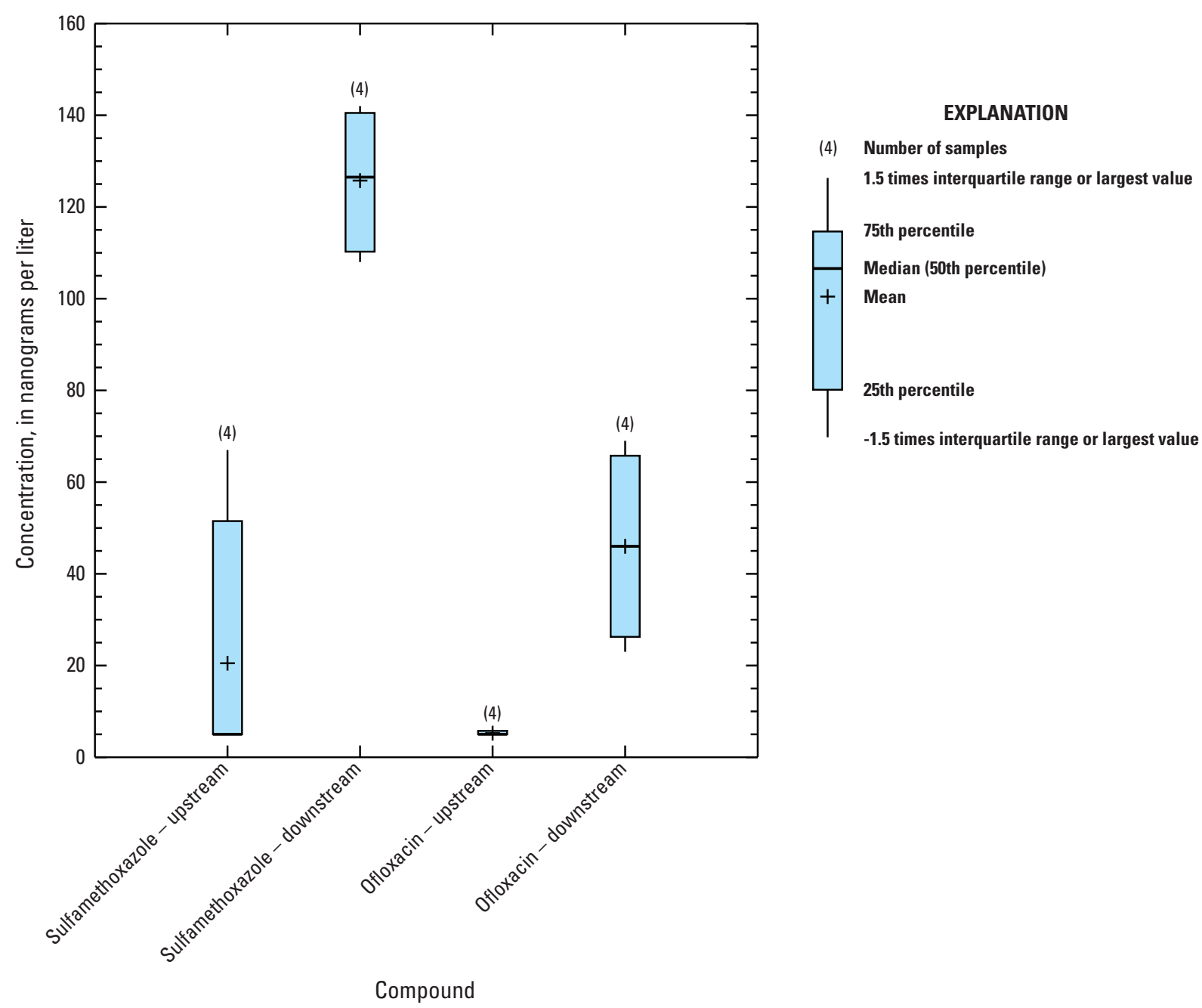

Figure 10. Sulfamethoxazole and ofloxacin concentrations detected in samples collected from Lititz Creek near Lititz, Pennsylvania, the upstream site, T12, 01576420 and Lititz Creek at Rothsville, Pennsylvania, the downstream site, T13, 01576422, in 2006. 
Table 15. Description of sampling sites downstream from wastewater-effluent-discharge sites, number of compounds detected, total number of detections, average flow difference between upstream and downstream sampling sites, and drainage area for streamwater samples collected in Pennsylvania, 2006.

\begin{tabular}{|c|c|c|c|c|c|c|}
\hline $\begin{array}{c}\text { U.S. Geological } \\
\text { Survey station } \\
\text { identification } \\
\text { number }\end{array}$ & $\begin{array}{c}\text { Map } \\
\text { identification } \\
\text { number } \\
\text { (figure 1) }\end{array}$ & Stream & $\begin{array}{l}\text { Number of } \\
\text { compounds } \\
\text { detected at } \\
\text { concentrations } \\
\text { greater than } \\
\text { reporting level }\end{array}$ & $\begin{array}{l}\text { Total number of } \\
\text { detections at } \\
\text { concentrations } \\
\text { greater than } \\
\text { reporting level }\end{array}$ & $\begin{array}{c}\text { Average flow } \\
\text { difference } \\
\text { between } \\
\text { upstream and } \\
\text { downstream } \\
\text { sites' } \\
\text { (percent) }\end{array}$ & $\begin{array}{r}\text { Drainage area } \\
\text { (square miles) }\end{array}$ \\
\hline \multicolumn{7}{|c|}{ Stream sites downstream from wastewater-effluent-discharge sites } \\
\hline 01470858 & $\mathrm{~T} 2$ & $\begin{array}{l}\text { Spring Creek near Brownsville, } \\
\text { Pa. }\end{array}$ & 8 & 19 & 7 & 19.6 \\
\hline 015693158 & $\mathrm{~T} 4$ & $\begin{array}{l}\text { Middle Spring Creek above Burd } \\
\text { Run below Shipensburg, Pa. }\end{array}$ & 10 & 36 & 22 & 20.7 \\
\hline 01571195 & T6 & $\begin{array}{l}\text { Mountain Creek at Mt Zion } \\
\text { at Mt Holly Springs, Pa. }\end{array}$ & 7 & 7 & 5 & 47.1 \\
\hline 01573153 & $\mathrm{~T} 8$ & $\begin{array}{l}\text { Killinger Creek DS Treatment } \\
\text { Plant near Annville, Pa. }\end{array}$ & 19 & 52 & 49 & 13.8 \\
\hline 01576422 & T13 & Lititz Run at Rothsville, Pa. & 14 & 34 & 40 & 13.3 \\
\hline
\end{tabular}

${ }^{1}$ Flow difference between the upstream and downstream sites is the result of wastewater-effluent discharge and growndwater inputs.

which discharges effluent to Killinger Creek, has a design flow of 2.2 cubic feet per second $\left(\mathrm{ft}^{3} / \mathrm{s}\right)$. In 2008 , the annual average flow from this plant was $1.3 \mathrm{ft}^{3} / \mathrm{s}$ (Gannett Fleming, 2009). The large percentage of flow from wastewater effluent reduces the amount of dilution that can occur and can lead to increased loads of contaminants. The average streamflow difference between the upstream and downstream sampling sites at the other four wastewater-effluent-discharge sites ranged from 5 percent at Mountain Creek to 40 percent at Lititz Run (table 15).

Conoy Creek, where there is no waste effluent entering the stream, provides additional evidence of the presence of contaminants of emerging concern that are not related to a direct point source. Four pharmaceutical compounds were detected in samples from Conoy Creek. Acetaminophen was detected at concentrations greater than the reporting level in three of eight samples with a concentration range of 14 to $350 \mathrm{ng} / \mathrm{L}$. Caffeine was detected at concentrations greater than the reporting level in all eight samples with a concentration range of 15 to $363 \mathrm{ng} / \mathrm{L}$. Cotinine was detected in one of eight samples at a concentration of $17 \mathrm{ng} / \mathrm{L}$, which is greater than the reporting level. The veterinary antibiotic tylosin was the only antibiotic detected in samples from Conoy Creek. It was detected in six of the eight samples at concentrations ranging from 5 to $30 \mathrm{ng} / \mathrm{L}$. The presence of caffeine and tylosin indicates that human and animal waste entered Conoy Creek. These wastes are most likely related to on-lot septic systems or urban and agricultural land use.

\section{7 to 2009 Sampling Downstream from Wastewater-Effluent Discharges}

From 2007 to 2009 streamwater and streambed-sediment samples were collected annually at eight sites (table 5) located downstream from a wastewater-effluent discharge and analyzed for contaminants of emerging concern. Samples also were collected from Clark Creek (a reference site), which receives no wastewater-effluent discharge. Four of the 119 (3 percent) compounds analyzed in streamwater samples and 24 of the 98 (24 percent) compounds analyzed in streambedsediment samples collected from Clark Creek were detected at least once at concentrations greater than the reporting level. At the eight sites located downstream from wastewater-effluent discharges, 54 of the 119 ( 45 percent) compounds analyzed in streamwater samples and 51 of the 98 (52 percent) compounds analyzed in streambed-sediment samples were detected at least once at concentrations greater than the reporting level. These results are similar to the results for the 2006 sampling at the paired sampling sites upstream and downstream from wastewater-effluent-discharge sites for which more contaminants of emerging concern were detected at sites downstream from wastewater-effluent discharges than at upstream sites.

Nine of 13 pharmaceutical compounds (excluding antibiotics) analyzed were detected in streamwater samples from the eight sites located downstream from a wastewatereffluent discharge from 2007 to 2009. Acetaminophen, caffeine, codeine, cotinine, diphenhydramine, carbamazepine, 
and diltiazem were detected at concentrations greater than the reporting level. Ibuprofen and dehydronifedipine were detected only at concentrations less than the reporting level (table 16). Caffeine (detected once at $9 \mathrm{ng} / \mathrm{L}$ ) was the only pharmaceutical compound (excluding antibiotics) detected in the three samples collected from the reference site (Clark Creek). The pharmaceutical compounds (excluding antibiotics) most frequently detected at concentrations greater than the reporting level are the anticonvulsant drug carbamazepine (87 percent of samples), caffeine (67 percent), and the antihistamine diphenhydramine (46 percent). The pharmaceutical compounds (excluding antibiotics) detected in the greatest concentrations were caffeine (440 $\mathrm{ng} / \mathrm{L})$, carbamazepine (212 ng/L), and acetaminophen (158 ng/ L). Samples from the downstream site on Killinger Creek (T8, 01573153) had the greatest number of pharmaceutical compounds (excluding antibiotics) detected (7), the most total detections (14, fig. 11), and the highest concentrations detected for six of the seven pharmaceutical compounds (excluding antibiotics) detected. No pharmaceutical compounds (excluding antibiotics) were detected in the samples collected from the downstream site on Mountain Creek (T6, 01571195).

Eleven antibiotic compounds were detected at least once in streamwater or streambed-sediment samples collected at the eight sites downstream from a wastewater-effluent-discharge site from 2007 to 2009. Clark Creek (reference site) had one antibiotic detected in the three streamwater samples collected and one antibiotic detected in the three streambed-sediment samples collected. Detections of all antibiotics were at concentrations greater than the reporting level. The antibiotics that were frequently detected in streamwater or streambedsediment samples are azithromycin, erythromycin and its metabolite erythromycin- $\mathrm{H}_{2} \mathrm{O}$, ciprofloxacin, ofloxacin, sulfamethoxazole, tetracycline, and trimethoprim (table 16). Some compounds were detected more frequently in streamwater samples (sulfamethoxazole and erythromycin), whereas others were detected more frequently in streambed-sediment samples (tetracycline and ciprofloxacin). The maximum concentration of an antibiotic in streamwater samples was $1,150 \mathrm{ng} / \mathrm{L}$ of sulfamethoxazole, and the maximum concentration of an antibiotic in streambed-sediment samples was $1,760 \mu \mathrm{g} / \mathrm{kg}$ for ciprofloxacin. Streamwater and streambed-sediment samples from Killinger Creek (T8, 01573153) had the most total detections. The maximum concentrations detected for six of the nine antibiotics in streamwater samples and seven of nine antibiotics in streambed-sediment samples were also detected in samples collected from Killinger Creek (T8, 01573153). Two antibiotic compounds were detected in the streamwater and streambed-sediment samples from Mountain Creek (T6, 01571195), the fewest for the eight sites sampled downstream from wastewater-effluent discharge.

Eight of the 19 hormones and animal sterol compounds analyzed in streamwater samples and 15 of the 19 hormones and animal sterol compounds analyzed in streambed-sediment samples were detected at least once at concentrations greater than their reporting levels at the eight sites located downstream from a wastewater-effluent-discharge site from 2007 to 2009. For Clark Creek (reference site) no hormones or animal sterols were detected in the streamwater samples, but two hormones and two animal sterols (6 total detections) were detected in the three streambed-sediment samples collected (table 17). The natural estrogen estrone was the hormone compound detected most frequently in both streamwater and streambed-sediment samples (table 17). Most hormones were present in streamwater and streambed-sediment samples at similar detection frequencies. The natural androgen 4-androstene-3,17-dione was present more frequently in streamwater samples than in streambed-sediment samples, and the animal sterols cholesterol and 3-beta-coprostanol were detected more frequently in streambed-sediment samples. The natural estrogen 17-beta-estradiol and the synthetic estrogen 17-alpha-ethynylestradiol are known to have endocrine disrupting potential but were rarely detected. The hormone 17-beta-estradiol was detected in four streamwater samples $(0.5-0.9 \mathrm{ng} / \mathrm{L})$ and in eight streambed-sediment samples $(0.1-1.9 \mu \mathrm{g} / \mathrm{kg})$, and 17-alpha-ethynylestradiol was detected in two streambed-sediment samples $(0.3-1.7 \mu \mathrm{g} / \mathrm{kg})$. Overall, the detection of hormones and animal sterols was rare; most compounds were detected in less than 20 percent of the samples. The exception to this was estrone, which was detected in 50 percent of streamwater samples and 96 percent of streambed-sediment samples. The hormones detected in the greatest concentrations were estrone, which was detected in streamwater samples $(25 \mathrm{ng} / \mathrm{L})$, and progesterone, which was detected in streambed-sediment samples $(8.4 \mu \mathrm{g} / \mathrm{kg})$. The animal sterol cholesterol was detected at concentrations ranging from 2,230 to 9,760 ng/L in streamwater samples and from 1,700 to $115,000 \mu \mathrm{g} / \mathrm{kg}$ in streambed-sediment samples. The animal sterol 3-beta-coprostanol was detected at concentrations of 2,500 to 4,520 ng/L in streamwater and 330 to $10,600 \mu \mathrm{g} / \mathrm{kg}$ in streambed-sediment samples (table 17). Samples from Killinger Creek (T8, 01573153) had the most total detections of hormones and animal sterols in streamwater and streambed-sediment samples (figs. 11 and 12). The maximum concentrations detected for seven of the eight hormones and animal sterols in streamwater samples and six of nine hormones and animal sterols in streambed-sediment samples were detected in samples collected from Killinger Creek (T8, 01573153). Quittapahilla Creek (T9, 01573160) had the least total detections (1) of hormones and animal sterols in the streamwater samples, and Clark Creek (T14, 01568590) had the least detections (4) of hormones and animal sterols in streambed-sediment samples.

Forty of the 56 OWCs analyzed in streamwater samples and 34 of 51 OWCs analyzed in streambed-sediment samples were detected at least once at the eight sites located downstream from wastewater-effluent-discharge sites from 2007 to 2009 (table 18, at end of report). Four of 56 OWCs analyzed in streamwater samples and 21 of 51 OWCs analyzed in streambed-sediment samples were detected at least once in the three samples collected from the reference site located on Clark Creek (table 18). The OWCs most frequently detected 


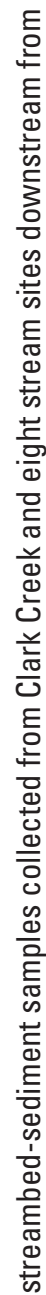

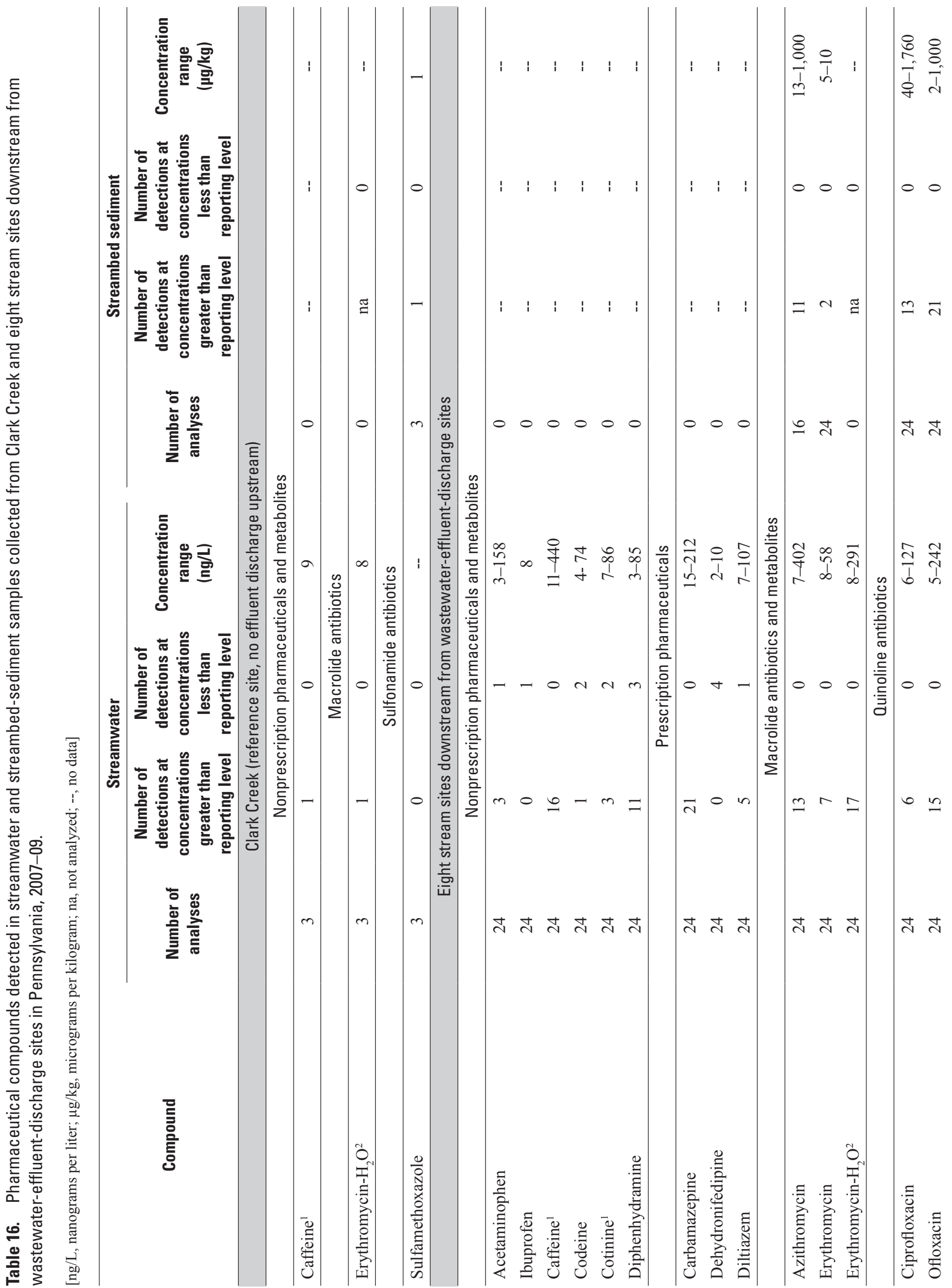




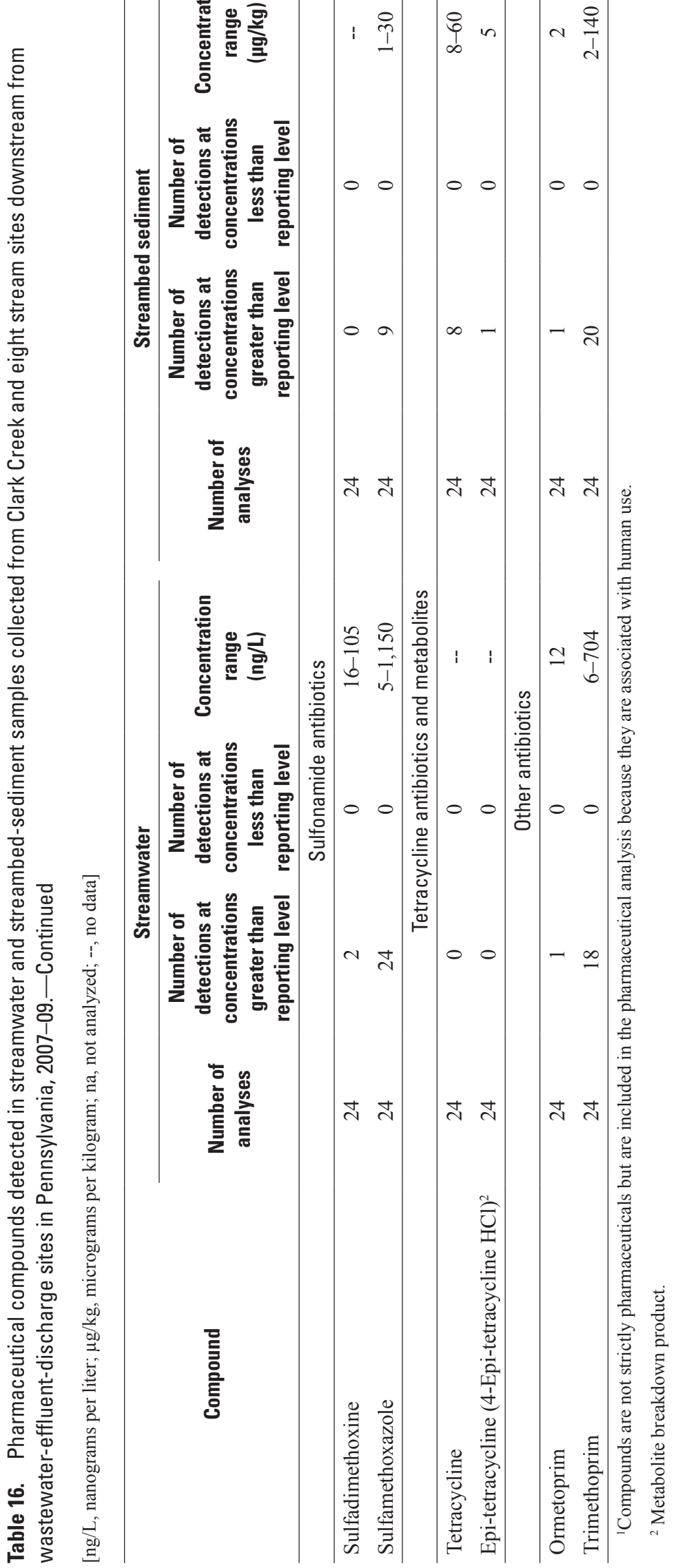




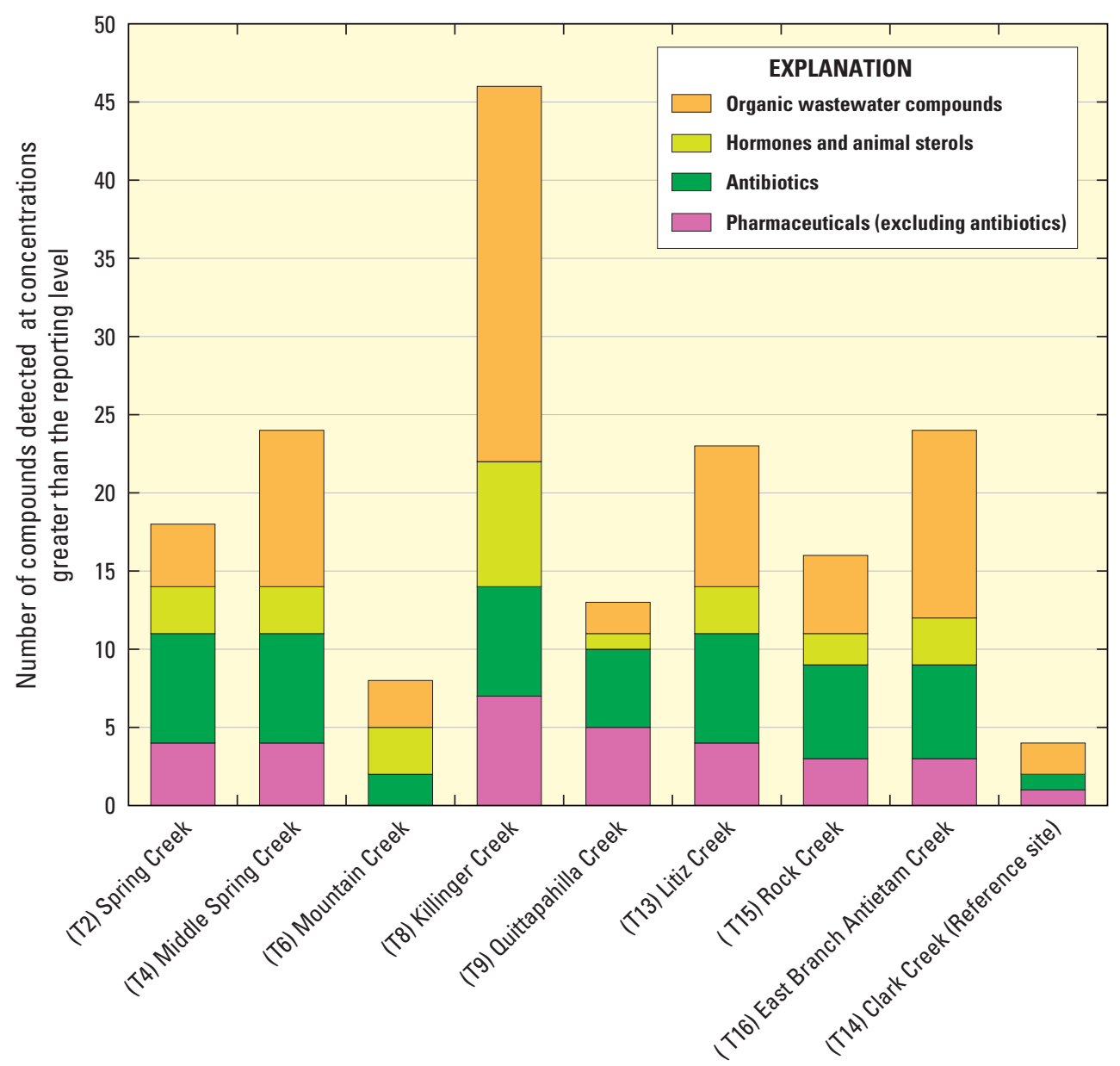

Sampling site

Figure 11. Number of contaminants of emerging concern detected at concentrations greater than the reporting level in streamwater samples collected from sites downstream from municipal wastewater-effluent-discharge sites in Pennsylvania, 2007-09. 


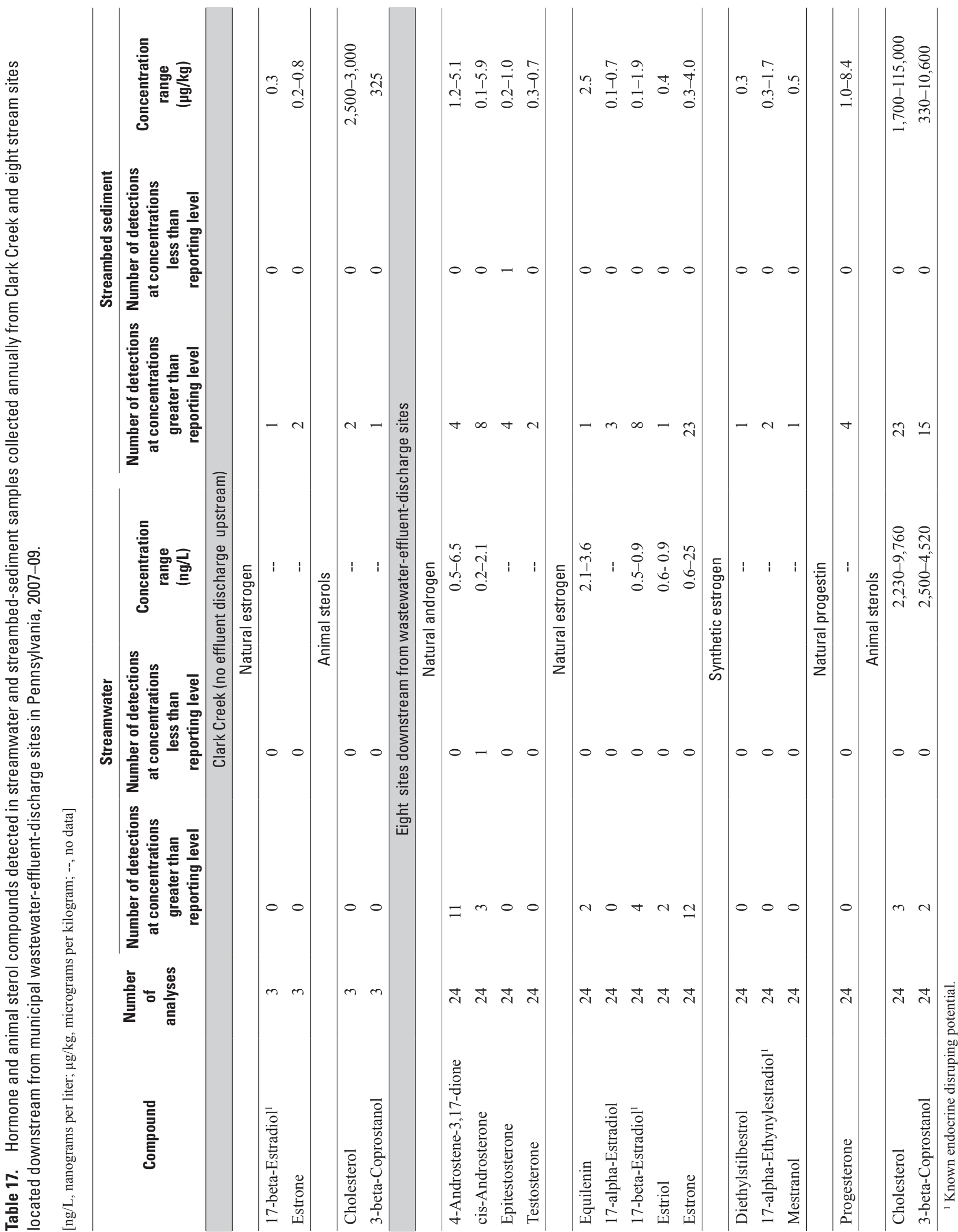




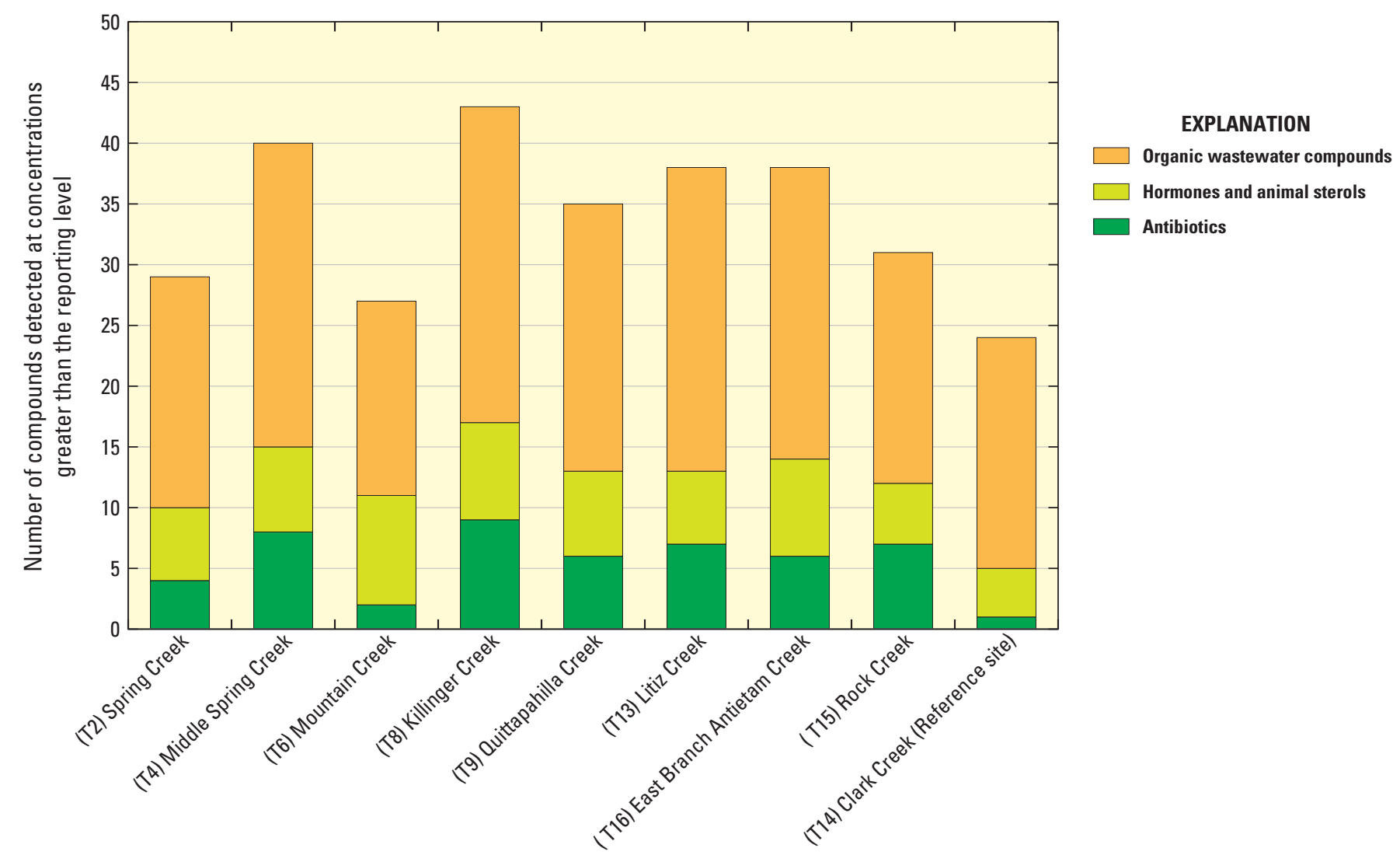

Sampling site

Figure 12. Number of contaminants of emerging concern detected at concentrations greater than the reporting level in streambedsediment samples collected from the Clark Creek reference site and eight stream sites located downstream from municipal wastewatereffluent-discharge sites in Pennsylvania, 2007-09. 
in streamwater at eight sites downstream from wastewatereffluent-discharge sites at concentrations greater than their reporting levels are the flame retardants tri(dichloroisopropyl) phosphate (83 percent), tri(2-chloroethyl) phosphate (62 percent), and tri(2-butoxyethyl) phosphate (33 percent). Tri(dichloroisopropyl) phosphate and tri(2-chloroethyl) phosphate are suspected endocrine disruptors (Zaugg and others, 2002). The OWCs most frequently detected in streambed-sediment samples at eight sites downstream of wastewater-effluent-discharge sites at concentrations greater than their reporting levels are fluoranthene, phenanthrene, and pyrene (100 percent) and benzo[a]pyrene and beta-sitosterol (96 percent). Fluoranthene, pyrene, and beta-sitosterol had high (297-1,669 percent) recoveries reported for laboratory spiked environmental streambed-sediment samples; the reported concentrations of these compounds may be an overestimate of actual concentrations (Appendix C, table C-9). Other known or suspected endocrine disruptors detected in streamwater and streambed-sediment samples are detergent metabolites, pesticides, industrial compounds, disinfectants, and PAHs (table 18). Some compounds were found primarily in streamwater or streambed-sediment samples, and others were found in both mediums. Although the number of OWCs detected at least once in streamwater and streambed-sediment samples was similar, the detection frequency was greater for the streambed-sediment samples. There were two frequently detected compounds (detected in more than 50 percent of samples collected) in the 24 streamwater samples collected and there were 17 frequently detected compounds in the 24 streambed-sediment samples collected (table 18). The OWC detected in the greatest concentration in streamwater and streambed-sediment samples is nonylphenol, diethoxy(total, NPEO2) $(15,000 \mathrm{ng} / \mathrm{L}$ in a streamwater sample and $9,589 \mu \mathrm{g} / \mathrm{kg}$ in a streambed-sediment sample). Total, NPEO2 is a known endocrine disruptor (Zaugg and others, 2002).

Streamwater and streambed-sediment samples from Killinger Creek (T8, 01573153) had the highest number of detections of OWCs (fig. 11 and 12) of any of the sites located downstream from wastewater-effluent-discharge sites. The maximum concentrations detected for seven of the eight hormones and animal sterols in streamwater samples and six of nine hormones and animal sterols in streambed-sediment samples also were detected in samples collected from Killinger Creek (T8, 01573153). Killinger Creek had the highest concentrations detected for 19 of the 27 OWCs detected in streamwater samples and for 15 of the 28 OWCs detected in streambed-sediment samples. Quittapahilla Creek (T9, 01573160) had the fewest hormones and animal sterols and OWCs detected (2) in streamwater samples, and Mountain Creek (T6, 01571195) had the fewest total number of pharmaceuticals detected (3) in the streamwater samples collected at the eight sites located downstream from wastewater-effluentdischarge sites (fig. 11). Mountain Creek (T6, 01571195) had the fewest number of antibiotic and OWC detections (16) and the fewest total number of detections in streambed-sediment samples collected at the eight sites located downstream from wastewater-effluent-discharge sites (fig. 12).

Results from the 2006 sampling upstream and downstream from wastewater-effluent discharges indicate that all classes of compounds (pharmaceuticals, hormones, and OWCs) were detected in greater numbers, at increased detection frequencies, and at higher concentrations in samples downstream from a wastewater-effluent discharge. The detection patterns from the 2006 sampling along with the concentrations measured during the 2007 to 2009 sampling downstream from wastewater-effluent discharges, indicate that streams like Killinger Creek (T8, 01573153), to which wastewater-effluent discharge contributes a large percentage of the total flow, are likely to have higher numbers of compounds detected and at higher concentrations than streams such as Mountain Creek (T6, 01571195), which have relatively small percentages of the total flow attributable to wastewater effluent.

Although samples from the upstream sampling locations had fewer compounds detected, had compounds detected less frequently, and had compounds detected in smaller concentrations than the downstream locations, contaminants of emerging concern were, nevertheless, present upstream from the wastewater-effluent discharge. Non-point discharge contamination from on-lot septic systems and agricultural land use are the most likely sources of the contamination upstream from the wastewater-effluent discharges. Leaking sewer pipes and urban runoff also can be a source of contaminants of emerging concern (Phillips and Chalmers, 2009). Contaminants of emerging concern also were found more frequently in the streambed-sediment samples than in the streamwater samples. Antibiotic compounds were often found in both the water and sediment samples but some OWCs were found exclusively in the streambed-sediment samples and not in the streamwater samples (fig. 13). Streambed sediments can accumulate and store many organic wastewater compounds, then redistribute them downstream during periods of high flow, becoming an in-stream source of contamination.

\section{Compounds in Streamwaters near Drinking- Water Intakes}

Twenty-seven stream sampling sites near drinking-water intakes were sampled quarterly from March 2007 to September 2009 at various flow conditions and analyzed for pharmaceutical compounds and hormones in streamwater samples (fig. 14). The total number of samples analyzed, by compound, is 297 for pharmaceuticals (excluding antibiotics), 294 for antibiotics, and 270 for hormones. Nineteen of the 63 compounds analyzed were detected at least once at concentrations greater than the reporting level. All concentrations of pharmaceutical compounds measured at the sites near drinking-water intakes were within the range of concentrations previously reported in a national reconnaissance of untreated drinking-water sources across the United States (Focazio and others, 2008). 


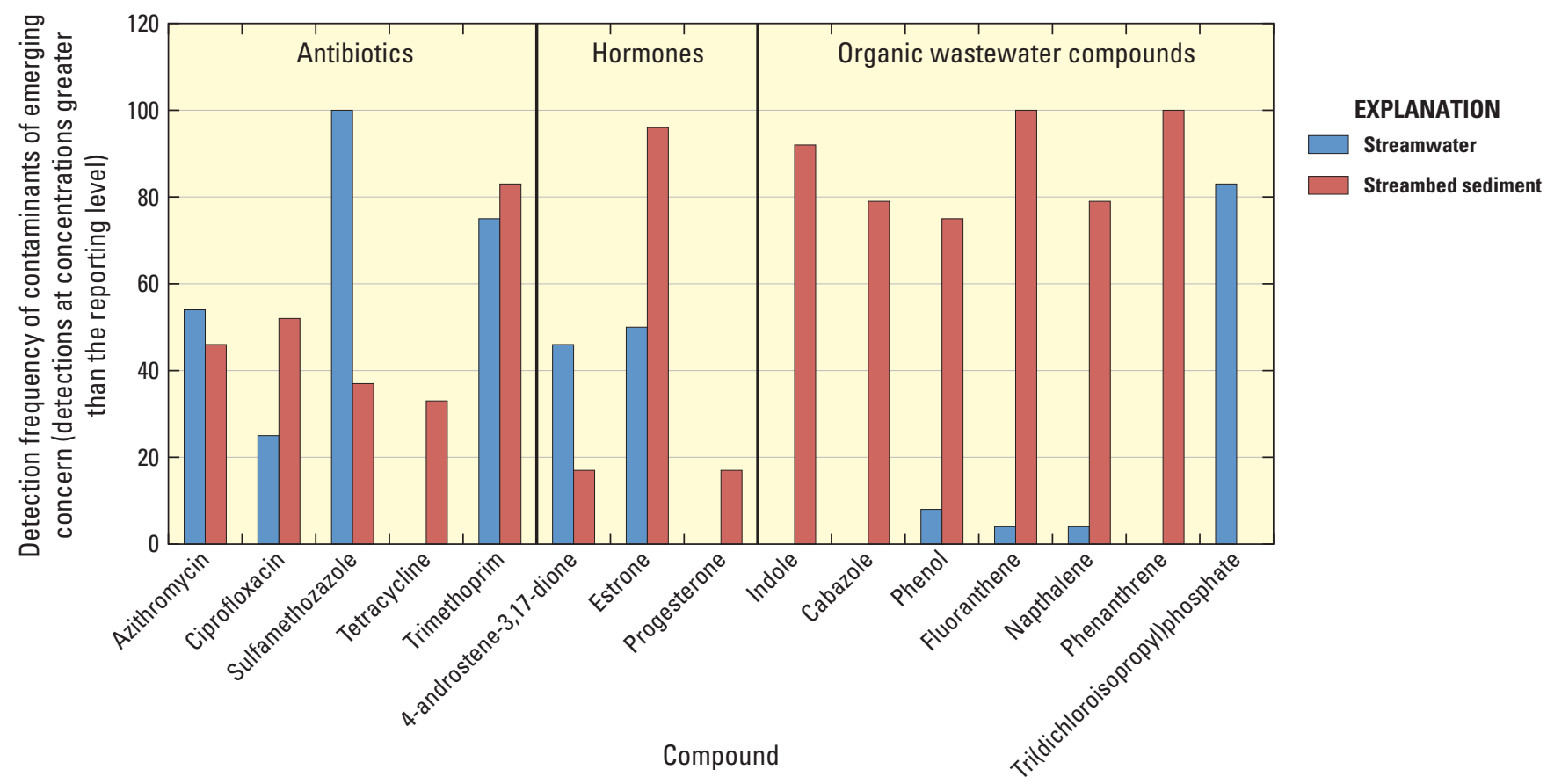

Figure 13. Detection frequency of selected contaminants of emerging concern detected at concentrations greater than the reporting level in streamwater and streambed-sediment samples collected from eight sites located downstream from municipal wastewatereffluent-discharge sites in Pennsylvania, 2007-09. (Detection frequency is detections at concentrations greater than the reporting level per number of samples.) 

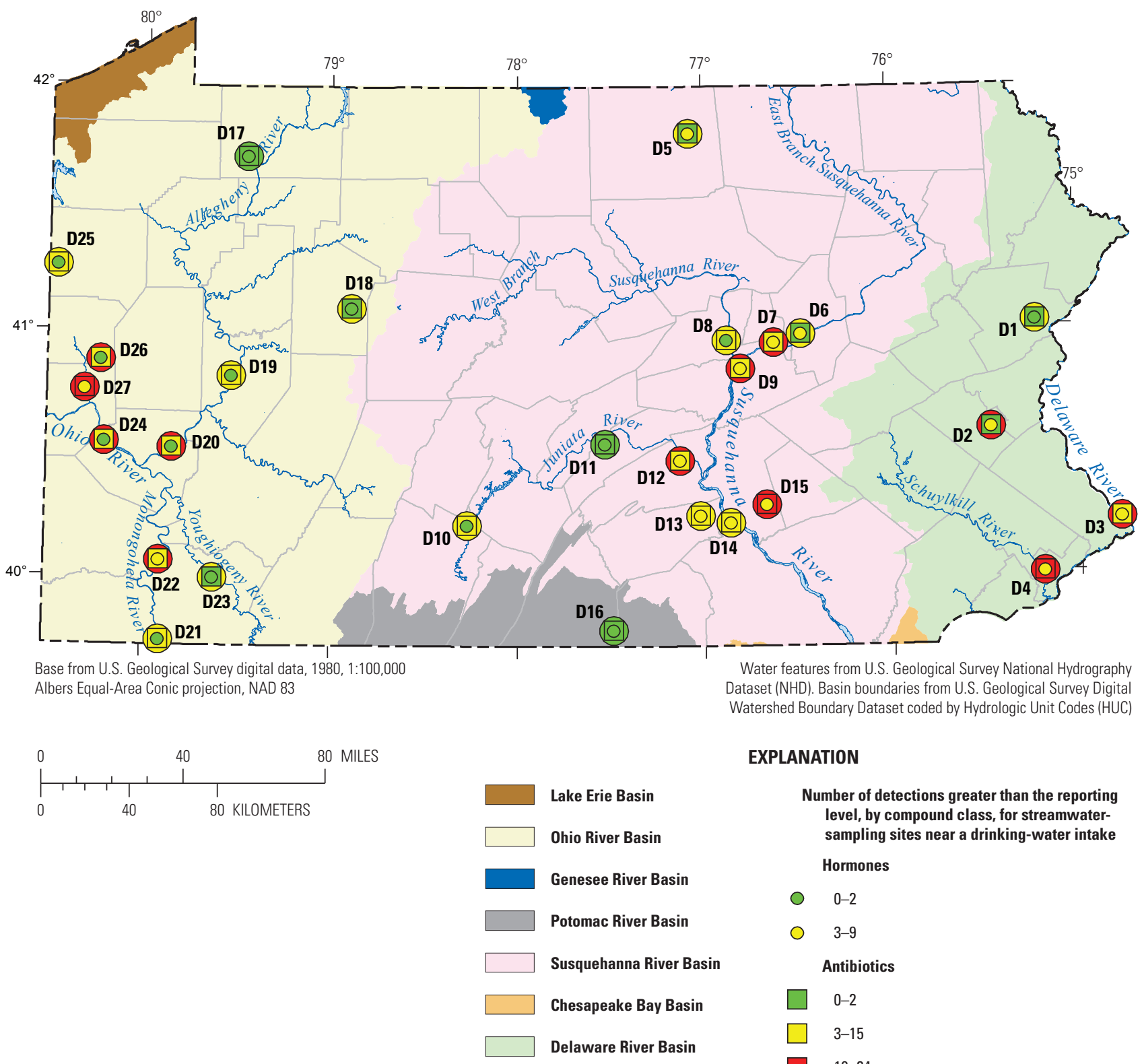

EXPLANATION

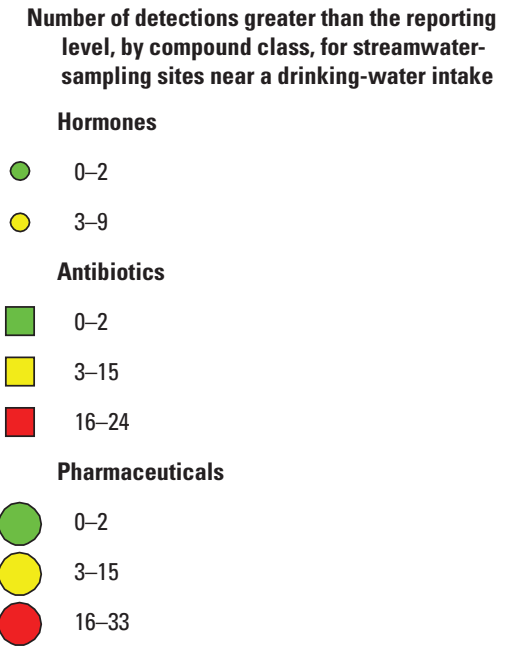

Figure 14. Locations of 27 streamwater-sampling sites near drinking-water intakes with the number of total detections at concentrations greater than the reporting level, by compound class, in Pennsylvania, 2007-09. 


\section{Pharmaceutical Compounds}

Seventeen of the 44 pharmaceutical compounds (table 1) were detected at the 27 stream sites located near a drinkingwater intake from 2007 to 2009 . Fourteen of the 17 compounds were detected at concentrations greater than the reporting level, and 3 compounds were detected at concentrations less than the reporting level (table 19, fig. 15). The pharmaceutical compounds most frequently detected at concentrations greater than the reporting levels were caffeine (71 percent), sulfamethoxazole (40 percent), acetaminophen ( 25 percent), carbamazepine ( 20 percent), trimethoprim ( 8 percent), paraxanthine (6 percent), and erythromycin- $\mathrm{H}_{2} \mathrm{O}$ (6 percent).

Acetaminophen, caffeine, carbamazepine, erythromycin- $\mathrm{H}_{2} \mathrm{O}$, para-xanthine, sulfamethoxazole, and trimethoprim accounted for 94 percent of all the pharmaceutical detections in the 297 samples collected. All other compounds were detected at concentrations greater than the reporting level in 3 percent or less of all samples (table 19). These results are consistent with results from a national USGS study that found acetaminophen, caffeine, carbamazepine, para-xanthine, and sulfamethoxazole, were among the most commonly detected contaminants of emerging concern nationwide (Kolpin and others, 2002). The pharmaceutical compounds detected in the greatest concentrations were caffeine $(517 \mathrm{ng} / \mathrm{L})$, acetaminophen $(210 \mathrm{ng} / \mathrm{L})$, sulfamethoxazole (146 ng/L), and para-xanthine (101 ng/L).

At least one pharmaceutical compound (including antibiotics) was detected at concentrations greater than the reporting level in samples from all 27 stream sites (fig. 16). The sampling locations with the most compounds detected and the most total detections at concentrations greater than the reporting level are the Schuylkill River (D4, 01474010; 10 compounds detected and 57 total detections), Beaver River (D27, 03107500; 10 compounds detected and 47 total detections), Susquehanna River at Sunbury (D9, 01553990; 8 compounds detected and 26 total detections), Swatara Creek (D15, 01562000; 10 compounds detected and 34 total detections), Susquehanna River at Danville (D7, 01553990; 7 compounds detected and 29 total detections), and Ohio River (D24, 03086000; 7 compounds detected and 39 total detections). Sampling locations with multiple detections at concentrations greater than $100 \mathrm{ng} / \mathrm{L}$ are the Schuylkill River (D4, 01474010), Jordan Creek (D2, 01452040), Monongahela River (D22, 03075001), Ohio River (D24, 03086000), and the Beaver River (D27, 03107500). The sampling locations with the fewest pharmaceutical compounds detected at concentrations greater than the reporting level are George Run (D17, 03015554) and East Branch Antietam Creek (D16, 01618800). Both sites had one compound that was detected one time (fig. 16).

Carbamazepine was the only prescription pharmaceutical commonly detected and sulfamethoxazole was by far the most commonly detected antibiotic. Detection of the remaining prescription pharmaceuticals and antibiotic compounds (fig. 15) was rare. All antibiotics detected are for human use except for tylosin, which is for veterinary use. Sulfamethoxazole was the antibiotic that was detected at the highest concentrations. It was detected at concentrations greater than $100 \mathrm{ng} / \mathrm{L}$ in three samples collected from the Schuylkill River (D4, 01474010) and in one sample collected from the Beaver River (D27, 03107500).

\section{Hormones}

Six of the 17 hormone and 2 animal sterol compounds were detected at least once in 270 samples collected from the 27 stream sites located near a drinking-water intake from 2007 to 2009 (table 19). Compounds detected at concentrations greater than the reporting levels were the hormones 4-androstene-3,17-dione, cis-androsterone, 17-alpha-estradiol, estriol, and estrone and the animal sterols cholesterol and 3-betacoprostanol (fig. 17). The hormone 17-beta-estradiol was detected once at a concentration less than the reporting level. The most frequently detected hormones that were detected at concentrations greater than the reporting levels are estrone (detected in 18 percent of all samples), cis-androsterone ( 5 percent), and 4-androstene-3,17-dione ( 3 percent). All other compounds were detected in less than 1 percent of all samples. The only hormone detected from the 27 stream sites located near a drinking-water intake that is listed as an endocrine disruptor was 17-beta-estradiol. It was detected in one sample at a concentration below the reporting level.

The hormone compounds detected in the greatest concentrations in streamwater near drinking-water intakes are cis-androsterone (6.2 ng/L), estrone (3.1 ng/ L), and 4-androstene-3,17-dione (1.8 ng/L, table 19). The highest measured concentrations of cis-androsterone, estrone, and 4-androstene3,17-dione were detected in a sample collected from Jordan Creek (D2, 01452040). Estrone is a naturally occurring female hormone, and 4-androstene-3,17-dione and cis-androsterone are naturally occurring male hormones. The maximum concentrations of hormones detected are much lower than those of pharmaceuticals and antibiotics. The maximum concentration of any animal sterol detected in streamwater near drinkingwater intakes was $6,790 \mathrm{ng} / \mathrm{L}$ for cholesterol (table 19), which was detected in a sample collected from Susquehanna River at Danville (D7, 01540500). The sampling locations with the most compounds detected and the most total detections are Jordan Creek (D2, 01452040; 3 compounds detected and 9 total detections) and Susquehanna River at Danville (D7, 01540500; 4 compounds detected and 5 total detections). Eight of the 27 sites had no detections of hormone or animal sterol compounds at concentrations greater than the reporting levels in the 10 samples collected from each site (fig. 16). Detection of most of the hormone and animal sterol compounds was rare. Only 1.5 percent of the analyses ( 73 detections in 5,130 analytical results) resulted in a detection at a concentration greater than the reporting level. 
Table 19. Pharmaceutical and hormone and animal sterol compounds detected in streamwater samples collected from 27 stream sites located near drinking-water intakes in Pennsylvania, 2007-09.

[ng/L, nanograms per liter; <, less than]

\begin{tabular}{|c|c|c|c|c|c|c|}
\hline Compound & $\begin{array}{l}\text { Number of } \\
\text { analyses }\end{array}$ & $\begin{array}{l}\text { Number of } \\
\text { detections at } \\
\text { concentrations } \\
\text { greater than } \\
\text { reporting level }\end{array}$ & $\begin{array}{c}\text { Percent } \\
\text { detections at } \\
\text { concentrations } \\
\text { greater than } \\
\text { reporting level }\end{array}$ & $\begin{array}{l}\text { Number of } \\
\text { detections at } \\
\text { concentrations } \\
\text { less than } \\
\text { reporting level }\end{array}$ & $\begin{array}{c}\text { Percent } \\
\text { detections at } \\
\text { concentrations } \\
\text { less than } \\
\text { reporting level }\end{array}$ & $\begin{array}{c}\text { Concentration } \\
\text { range } \\
\text { (ng/L) }\end{array}$ \\
\hline \multicolumn{7}{|c|}{ Pharmaceutical compounds } \\
\hline \multicolumn{7}{|c|}{ Nonprescription pharmaceuticals and metabolites } \\
\hline Caffeine $^{1}$ & 297 & 212 & 71 & 6 & 2 & $6-517$ \\
\hline Para-xanthine $e^{1,2,3}$ & 297 & 17 & 6 & 0 & 0 & $11-101$ \\
\hline Codeine & 297 & 0 & 0 & 1 & $<1$ & 5 \\
\hline Cotinine $^{1}$ & 297 & 9 & 3 & 35 & 12 & $2-22$ \\
\hline Diphenhydramine & 297 & 0 & 0 & 20 & 7 & $1-6$ \\
\hline Diltiazem & 297 & 2 & 1 & 3 & 1 & $4-26$ \\
\hline Salbutamol & 297 & 4 & 1 & 0 & 0 & $9-12$ \\
\hline \multicolumn{7}{|c|}{ Macrolide antibiotics and metabolites } \\
\hline Azithromycin & 294 & 8 & 3 & 0 & 0 & $7-72$ \\
\hline Erythromycin- $\mathrm{H}_{2} \mathrm{O}$ & 294 & 18 & 6 & 0 & 0 & $8-70$ \\
\hline Roxithromycin & 294 & 1 & $<1$ & 0 & 0 & 10 \\
\hline Tylosin & 294 & 3 & 1 & 0 & 0 & 10 \\
\hline \multicolumn{7}{|c|}{ Quinoline antibiotics } \\
\hline \multicolumn{7}{|c|}{ Hormones and animal sterols } \\
\hline \multicolumn{7}{|c|}{ Natural androgen } \\
\hline 4-Androstene-3,17-dione & 270 & 7 & 3 & 2 & $<1$ & $0.37-1.8$ \\
\hline Cis-Androsterone & 270 & 13 & 5 & 2 & $<1$ & $0.32-6.2$ \\
\hline \multicolumn{7}{|c|}{ Natural estrogen } \\
\hline 17-alpha-Estradiol & 270 & 1 & $<1$ & 0 & 0 & 0.43 \\
\hline 17-beta-Estradiol ${ }^{4}$ & 270 & 0 & 0 & 1 & $<1$ & 0.39 \\
\hline Estriol & 270 & 1 & $<1$ & 2 & $<1$ & $0.23-0.44$ \\
\hline Estrone & 270 & 48 & 18 & 3 & 1 & $0.32-3.1$ \\
\hline \multicolumn{7}{|c|}{ Animal sterols } \\
\hline Cholesterol & 270 & 2 & $<1$ & 1 & $<1$ & $255-6,790$ \\
\hline 3-beta-Corprostanol & 270 & 1 & $<1$ & 0 & 0 & 3,170 \\
\hline
\end{tabular}

${ }^{1}$ Compounds are not strictly pharmaceuticals but are included in the pharmaceutical analysis because they are associated with human use.

${ }^{2}$ Metabolite breakdown product.

${ }^{3}$ Para-xanthine also know as 1,7 dimethylxanthine.

${ }^{4}$ Known endocrine disrupting potential. 


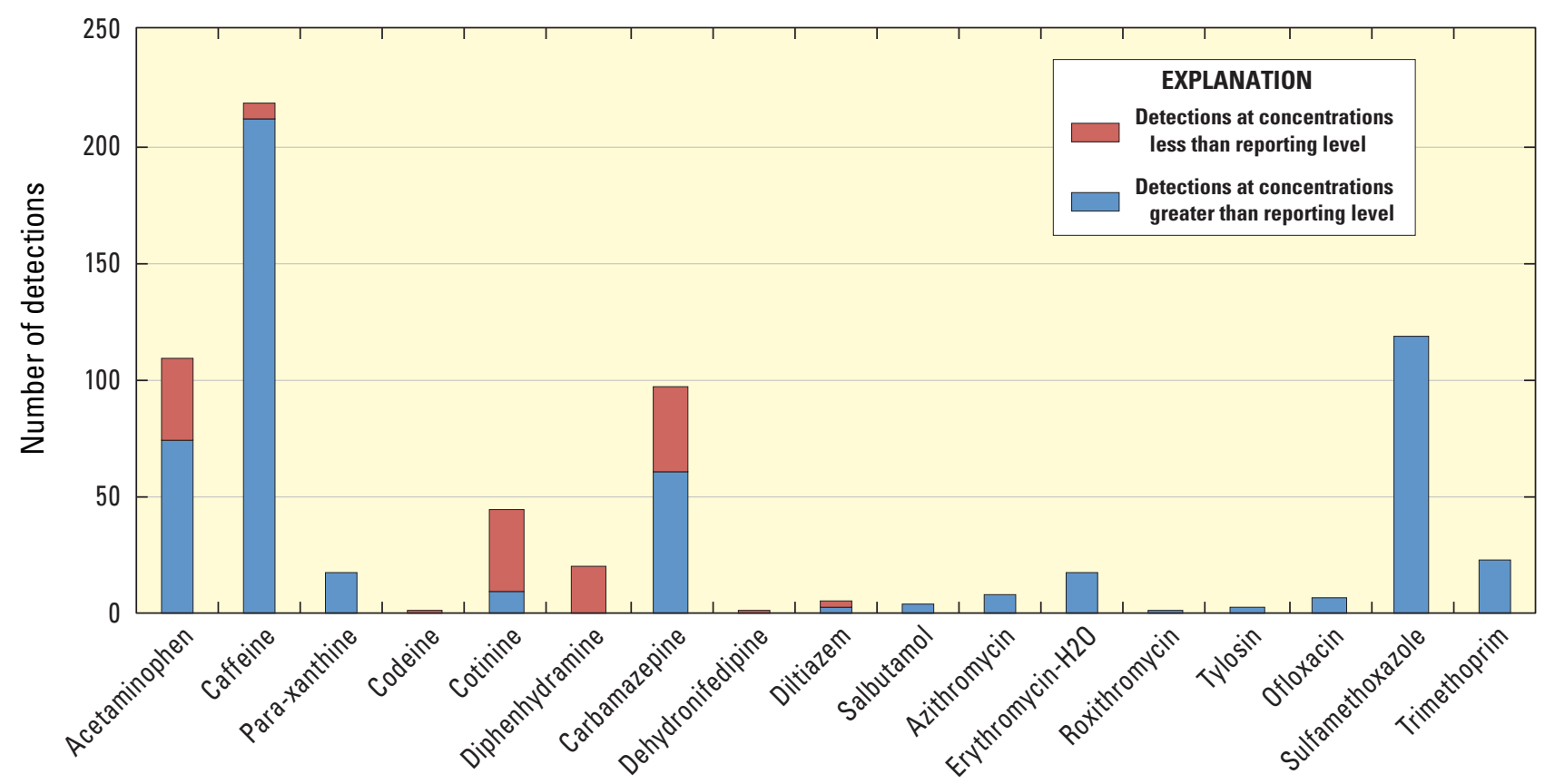

Pharmaceuticals

Figure 15. Number of detections of pharmaceutical compounds in streamwater samples collected from 27 stream sites located near drinking-water intakes in Pennsylvania, 2007-09. 


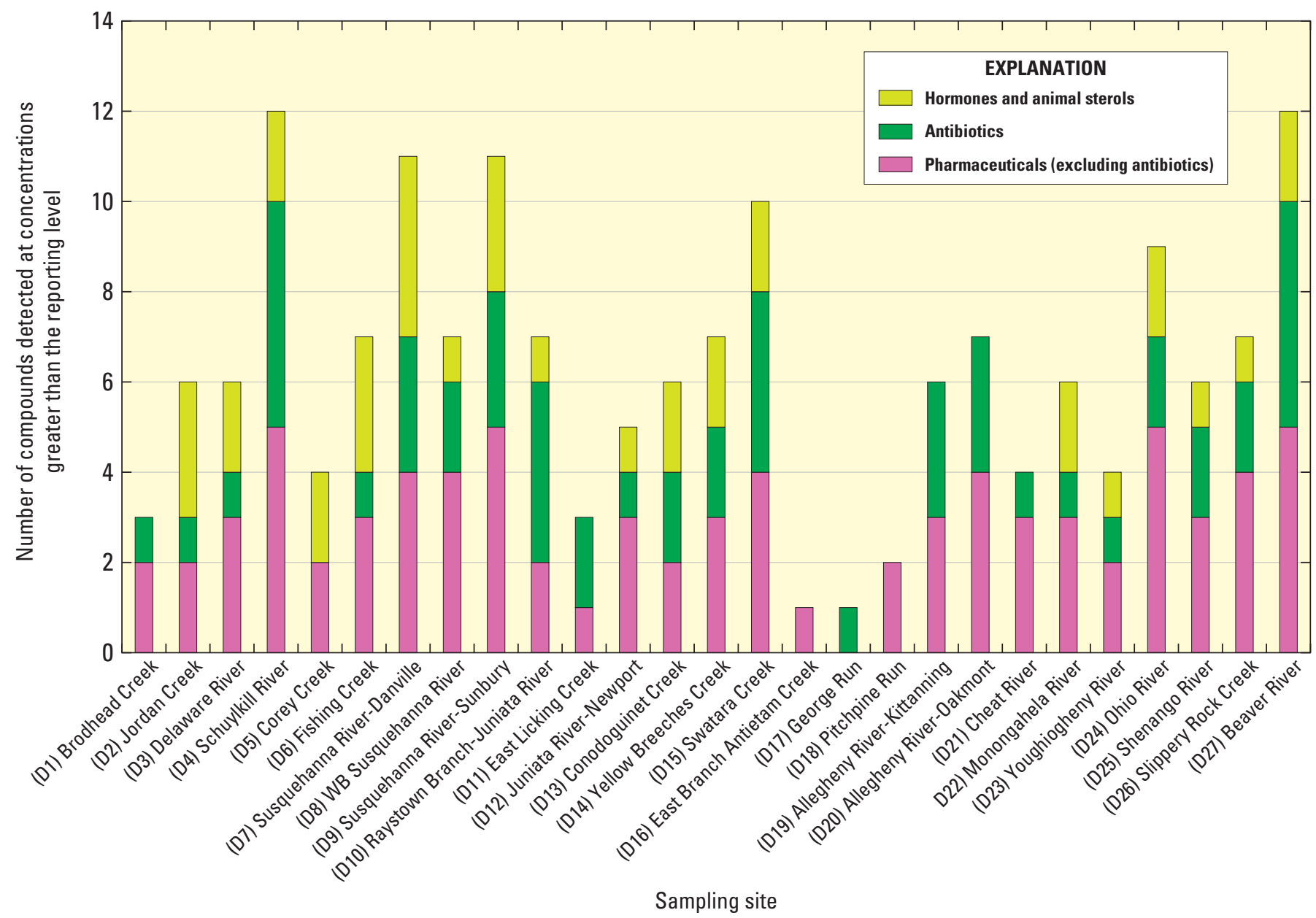

Figure 16. Number of contaminants of emerging concern detected at concentrations greater than the reporting level in streamwater samples collected from 27 stream sites near drinking-water intakes in Pennsylvania, 2007-09. 


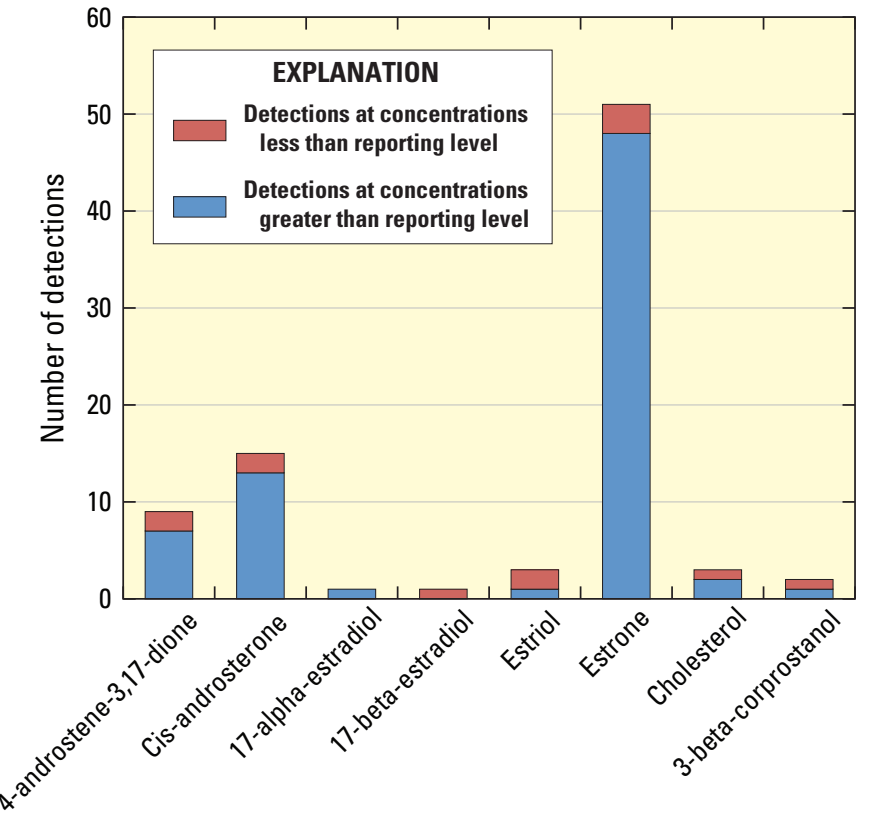

Hormone or animal sterol compounds

Figure 17. Number of detections of hormone and animal sterol compounds in 270 streamwater samples collected from 27 stream sites near drinking-water intakes in Pennsylvania, 2007-09.

\section{Patterns of Contaminant Occurrence}

Concentrations of contaminants of emerging concern in samples from sites near drinking-water intakes are often lower than the concentrations at the source as a result of dilution, sorption, volatilization, and degradation (Glassmeyer and others, 2005; Fono and others, 2006). Concentrations of contaminants of emerging concern in streams near drinking-water intake sites are dependent on many factors, including concentrations at the source, number of sources, source pathways, distance from the source, watershed size, and hydrologic conditions (Kolpin and others, 2002).

\section{Hydrologic Conditions}

Flow conditions can control the dilution of contaminants from point sources. During low-flow conditions, there may be little streamwater to dilute contaminants from a point source; therefore, in-stream concentrations typically are highest during low flows. Increases in streamflow can dilute the concentrations of contaminants from a point source, lowering the concentrations in stream samples, often to below detectable concentrations. For example, at the Schuylkill River at Philadelphia, Pa., (D4, 01474010), the concentration of the antibiotic sulfamethoxazole was inversely related to streamflow (fig. 18). The highest concentrations of sulfamethoxazole $(142 \mathrm{ng} / \mathrm{L}$ and $146 \mathrm{ng} / \mathrm{L})$ were measured when streamflow was lowest, and the lowest concentration of sulfamethoxazole
$(17 \mathrm{ng} / \mathrm{L})$ was measured when streamflow was highest, indicating that the concentration is controlled by in-stream dilution. There are 1,275 permitted discharges upstream from the Schuylkill River at Philadelphia, Pa., sampling site, which provide a steady source of contaminants to the stream.

The most commonly detected compounds had different patterns of detection related to streamflow (fig. 19). Carbamazepine and estrone followed patterns similar to that of sulfamethoxazole with the highest detection frequency for samples collected during low flows and lowest detection frequency for samples collected during higher flows. Other compounds did not follow the low-flow, high-detection frequency pattern. For example, acetaminophen and caffeine were found more frequently in samples collected during high flows (fig. 19). These apparent relations of concentration to flow conditions are a further indication that the occurrence and concentration of many of these compounds are variable and dependent on factors such as concentrations at the source, mode of transport from the source (point source, non-point source, combined sewer overflows), sorption, volatilization, and degradation. These factors can be compound specific. The occurrence and concentrations of contaminants of emerging concern also could be related to the contribution of flow from combined sewer overflows and decreased removal efficiency at wastewater-treatment plants during high-flow events (Philips and Chalmers, 2009).

\section{Number of Permitted Discharges}

One of the major factors controlling the occurrence of contaminants of emerging concern in a particular watershed is the number of wastewater, stormwater, and industrial discharges in the watershed relative to the base flow. As the amount of effluent water increases relative to non-effluent water, the dilution of organic waste compounds in the stream decreases, and concentrations of organic waste compounds become more detectable.

The 27 stream sites sampled were associated with different numbers of permitted discharges upstream from the sampling site. The number of permitted discharges ranged from 0 to 5,873 in drainage areas ranging from $1.82 \mathrm{mi}^{2}$ to $19,500 \mathrm{mi}^{2}$ (table 7). To analyze the effect of the number of permitted discharges on contaminant detections, the 27 sites were divided into three categories of wasteload - high, mid, and low ( 9 sites per category) — on the basis of the number of permitted discharges per unit of drainage area. This approach does not account for the differences in waste volumes at discharge sites and, therefore, is only an estimate of relative wasteloads to the streams. The largest number of detections occurred at sites where the ratio of discharges per square mile of drainage area was greater than 0.28 (fig. 20). The sites that fell into the high wasteload category (greater than 0.28 discharges per square mile of drainage area) ranged from relatively small streams like Yellow Breeches near New Cumberland, Pa. (D14, 01571505; $206 \mathrm{mi}^{2}$ ) to the Ohio River at Sewickley, Pa. (D24, $\left.03086000 ; 19,500 \mathrm{mi}^{2}\right)$. The 9 sites with greater than 0.28 


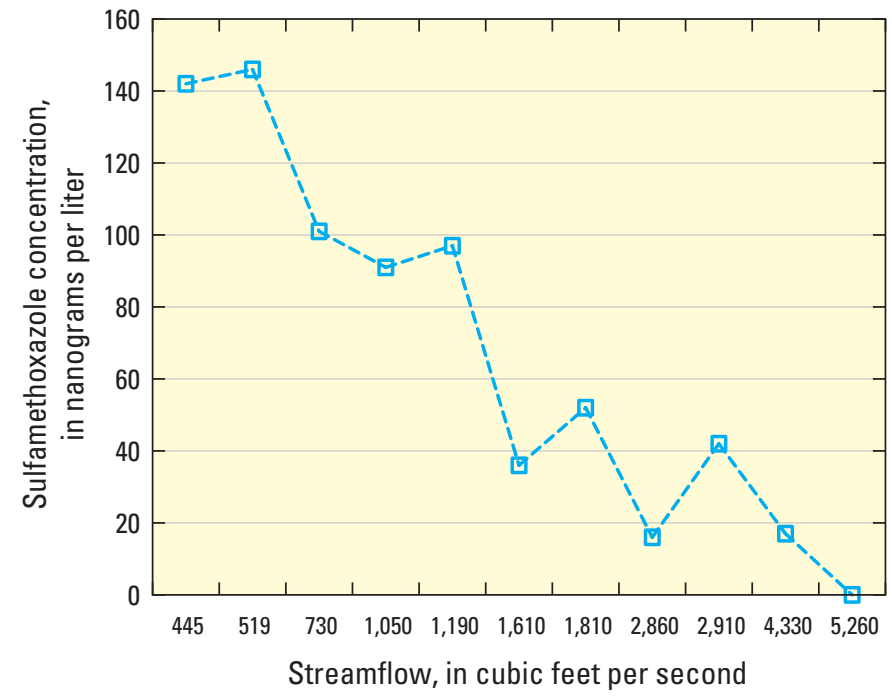

Figure 18. Concentration of sulfamethoxazole in streamwater samples collected from the Schuylkill River at Philadelphia, Pennsylvania, in relation to streamflow, 2007-09.

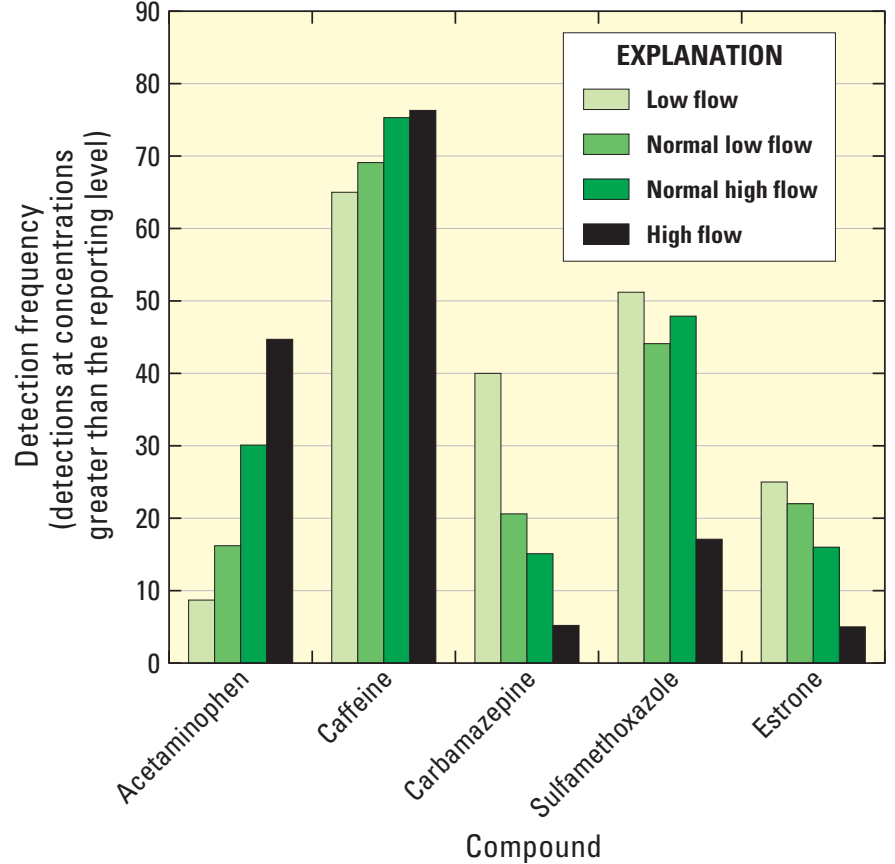

Figure 19. Detection frequency of commonly detected contaminants of emerging concern in each of four flow categories for streamwater samples taken from 27 stream sites located near drinking-water intakes in Pennsylvania, 2007-09. (Detections frequency is detections at concentrations greater than the reporting level per number of samples.)

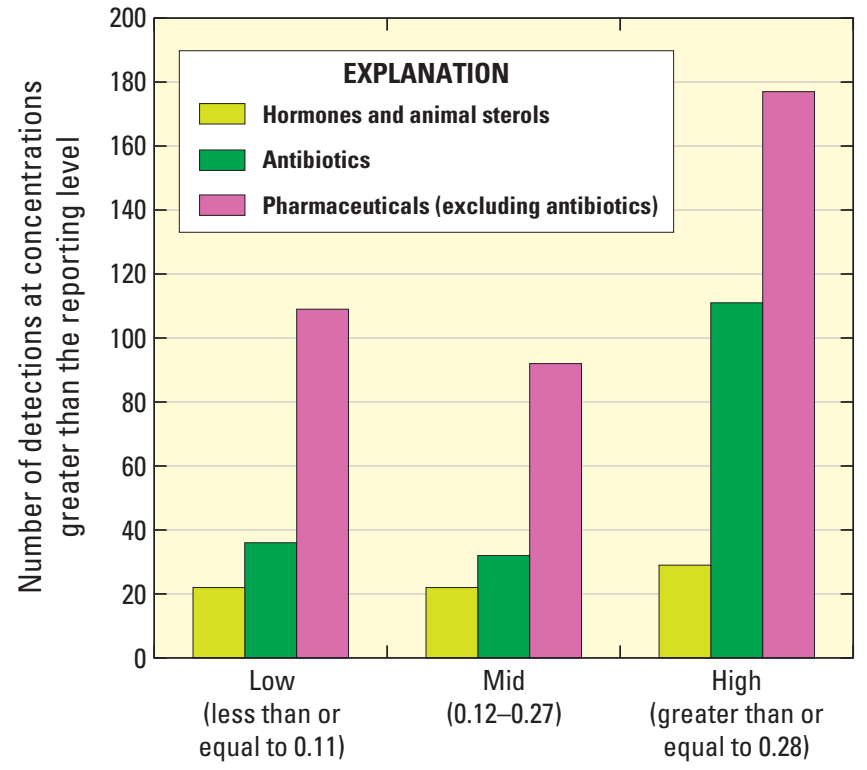

Total permitted discharges per drainage area

Figure 20. Number of detections of contaminants of emerging concern at concentrations greater than the reporting level by permitted discharges categories - low, mid, and highfor 27 stream sites located near drinking-water intakes in Pennsylvania, 2007-09. 
discharges per square mile of drainage area (high wasteload category) had more than double the number of detections of contaminants of emerging concern than the 18 sites that had less than 0.27 discharges per square mile of drainage area (mid and low wasteload categories). The four sites with the lowest number of discharges per unit of drainage area ratio had a total of 24 detections of contaminants of emerging concern, whereas the four sites with the highest discharges per unit of drainage area ratio had a total of 130 detections. For example, the Susquehanna River at Danville, Pa., (D7, 01540538), had 1,847 permitted discharge sites upstream from the sampling site and a drainage area of $11,220 \mathrm{mi}^{2}$ (or 0.16 discharges per $\mathrm{mi}^{2}$ ). The Schuylkill River at Philadelphia, Pa., (D4, 01474010) had 1,275 permitted discharge sites upstream from the sampling site and a drainage area of $1,893 \mathrm{mi}^{2}$ (or 0.67 discharges per $\mathrm{mi}^{2}$ ). Despite having more permitted discharges in the watershed, the Susquehanna River site (D7, 01540538) had fewer detections of contaminants of emerging concern (24 total detections) than the Schuylkill River site (D4, 01474010), which had 60 total detections. Dilution at the Susquehanna River site (50-percentile flow duration of 15,900 $\mathrm{ft}^{3} / \mathrm{s}$ ) reduced the constituent concentrations more than at the Schuylkill River site (50-percentile flow duration of 1,670 ft3 $/ \mathrm{s}$ ). The occurrence of more total detections at sites with greater than 0.28 discharges per drainage area (high wasteload category) was consistent for all five of the most frequently detected compounds (fig. 21). Concentrations of detected compounds also were greater at the sites with greater than 0.28 discharges per drainage area. The average concentration of sulfamethoxazole for the 29 detections at sites in the low wasteload category was $0.017 \mathrm{ng} / \mathrm{L}$, whereas the average concentration was $0.015 \mathrm{ng} / \mathrm{L}$ for the 22 detections in the mid wasteload category and $0.34 \mathrm{ng} / \mathrm{L}$ in the 66 detections in the high wasteload category. Acetaminophen, caffeine, carbamazepine, and estrone also were detected at the highest average concentrations in the samples collected from sites in the high wasteload category.

\section{Land Use}

Land use at the 27 sites near drinking-water intakes ranged from forest dominated watershed to agriculture or urban dominated watersheds. Forested land use at the 27 sites ranged from about 97 percent at East Licking Creek (D11, 01566005) to about 27 percent at Jordan Creek (D2, 01452040). Agricultural land use ranged from about 51 percent at Conodoguinet Creek (D13, 01570000) to 0 percent at East Licking Creek (D11, 01566005). Urban land use ranged from about 21 percent at Jordan Creek (D2, 01452040) to 0 percent at George Run (D17, 03015554) (table 20; Homer and others, 2004).

The occurrence of contaminants of emerging concern is generally related to patterns of land use in the watershed. Watersheds that have high percentages of forested lands and low percentages of agricultural and urban lands generally have few point discharges or AFO discharges. Increases in agricultural and urban land use increases the likelihood of wastewater

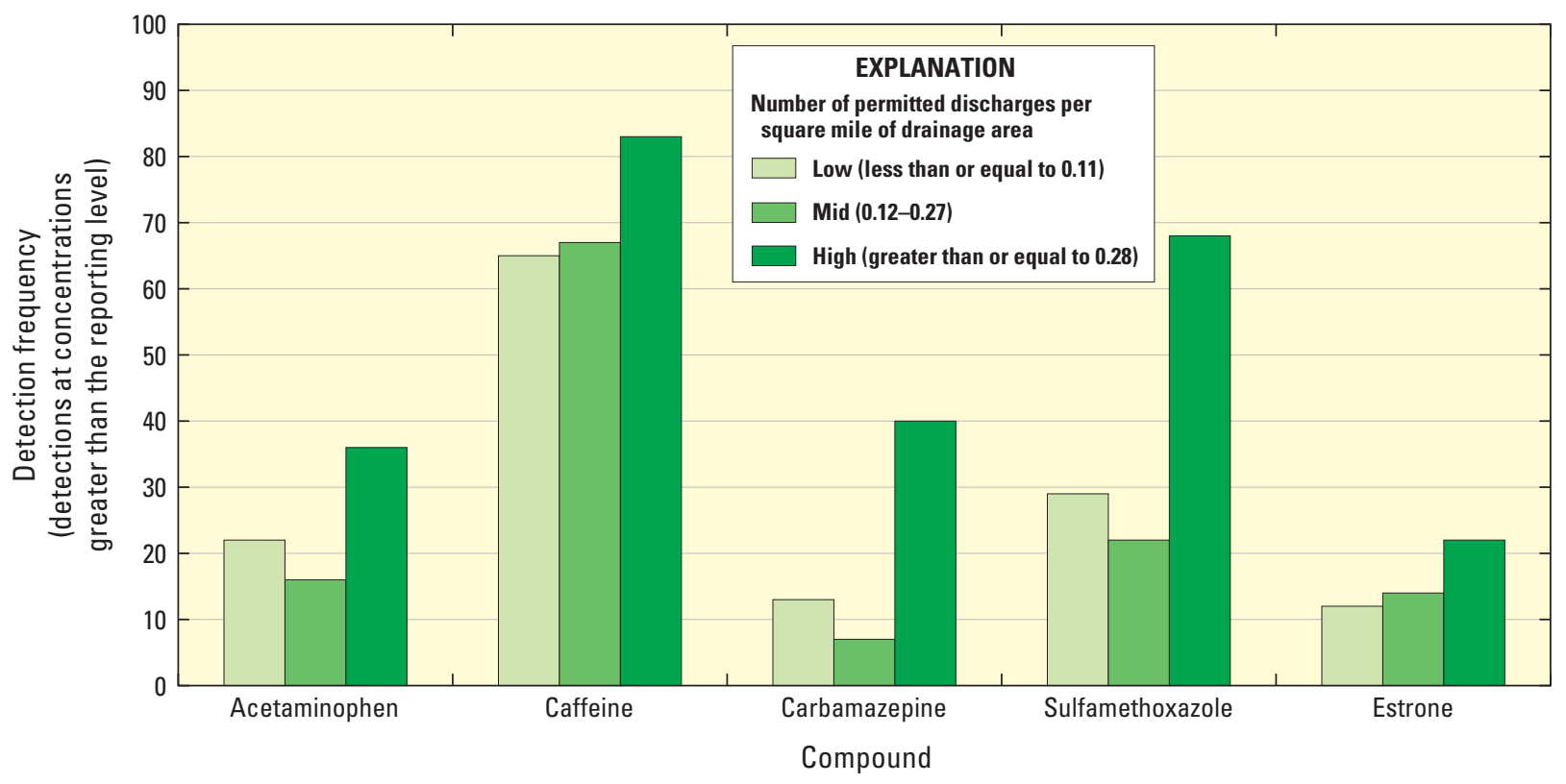

Figure 21. Detection frequency of selected contaminants of emerging concern by permitted discharge category-low, mid, and high-for 27 stream sites located near drinking-water intakes in Pennsylvania, 2007-09. (Detection frequency is detections at concentrations greater than the reporting level per number of samples.) 
䒿

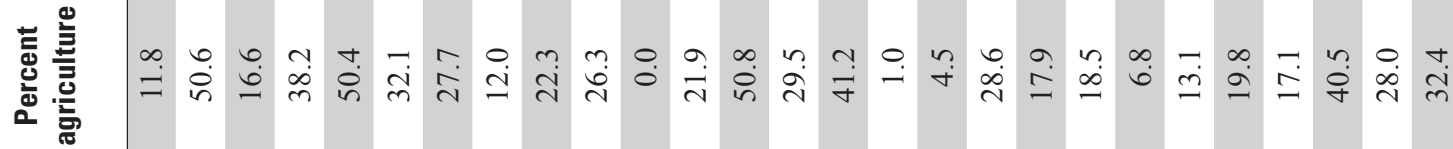

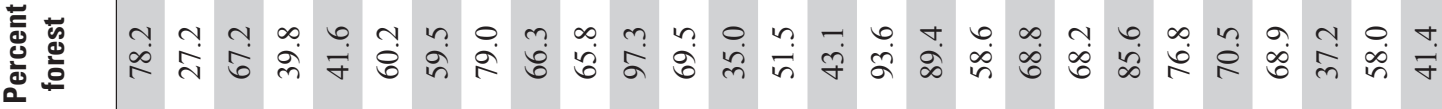

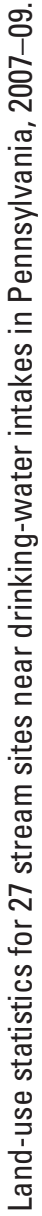

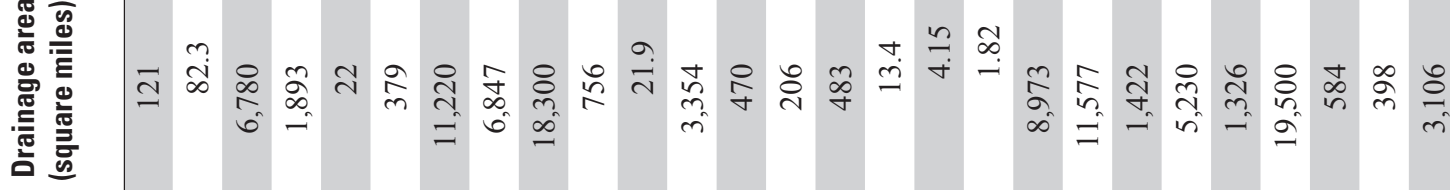

ลี่

竞 焉
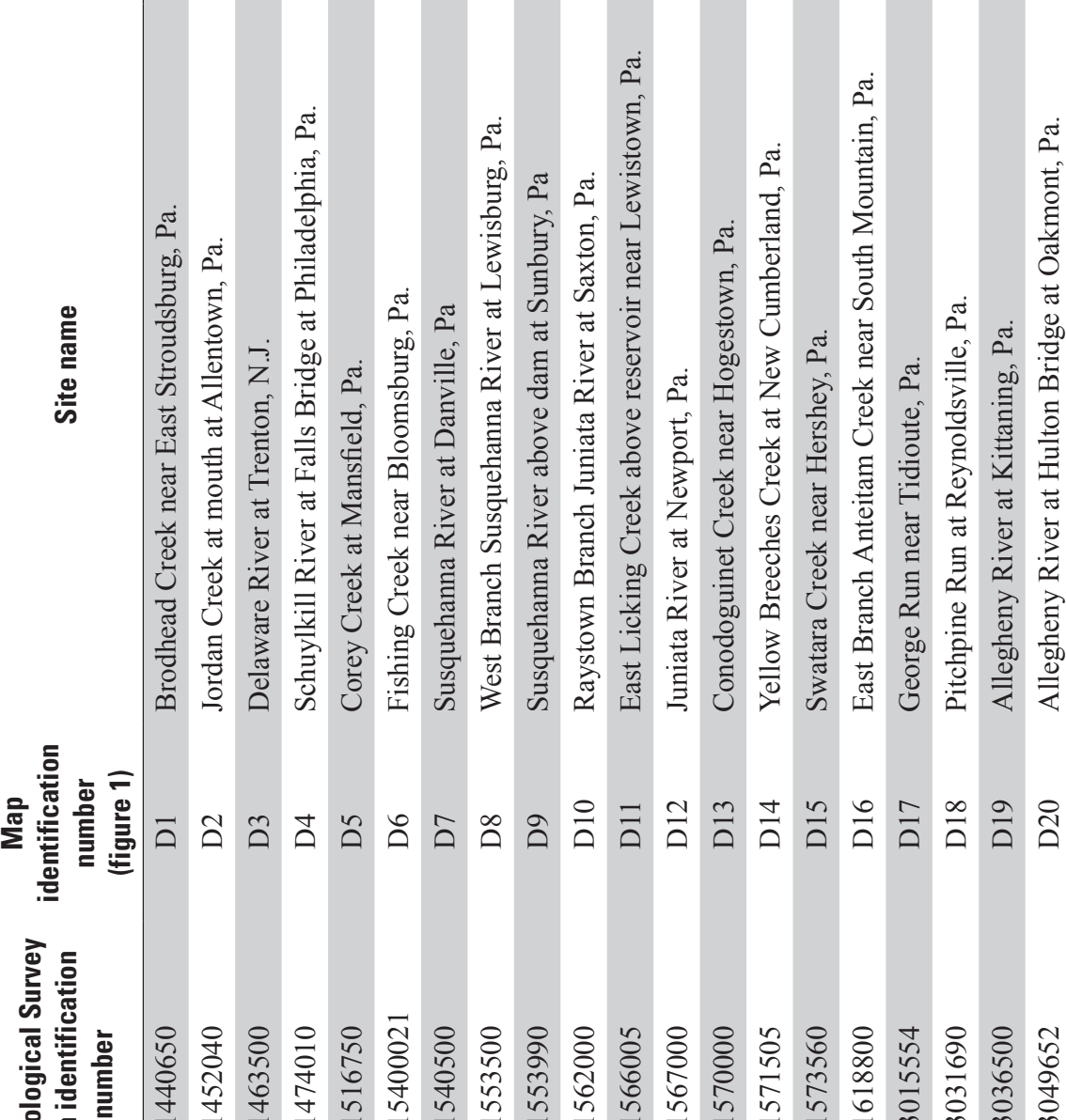

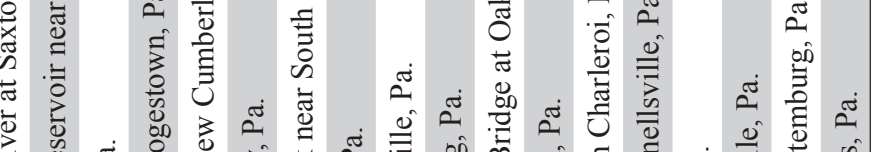



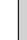

2

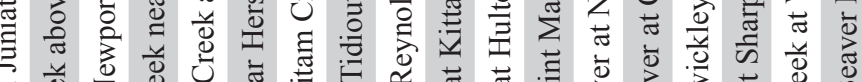
๘ bo

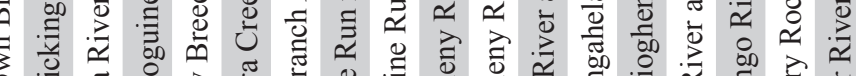

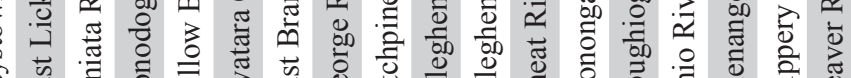

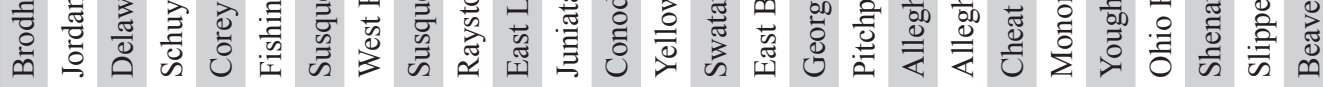

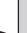
言

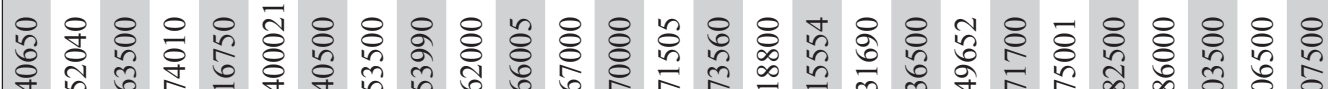

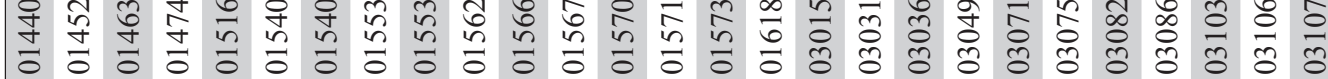
边

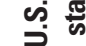


and AFO discharges. To analyze the effect of the land use on contaminant detections, the 27 sites were divided into three categories of high, mid, and low percentages of forested land use, urban land use, and agricultural land use ( 9 sites per category). There were relatively few detections of contaminants of emerging concern at sites in watersheds with high percentages (greater than 69 percent) of forested land use and low percentages of agricultural (less than 17 percent) and urban (less than 6.5 percent) land uses. The number of compounds detected increased as the percentage of forested land use decreased in the watershed (fig. 22).

George Run (D17, 03015554), East Licking Creek (D11, 01566005) and East Branch Antietam Creek (D16, 01618800) were all in the high category for the percentage of forested land use and in the low category for the percentage of agricultural and urban land uses (table 20). East Licking Creek and East Branch Antietam Creek had no permitted discharges

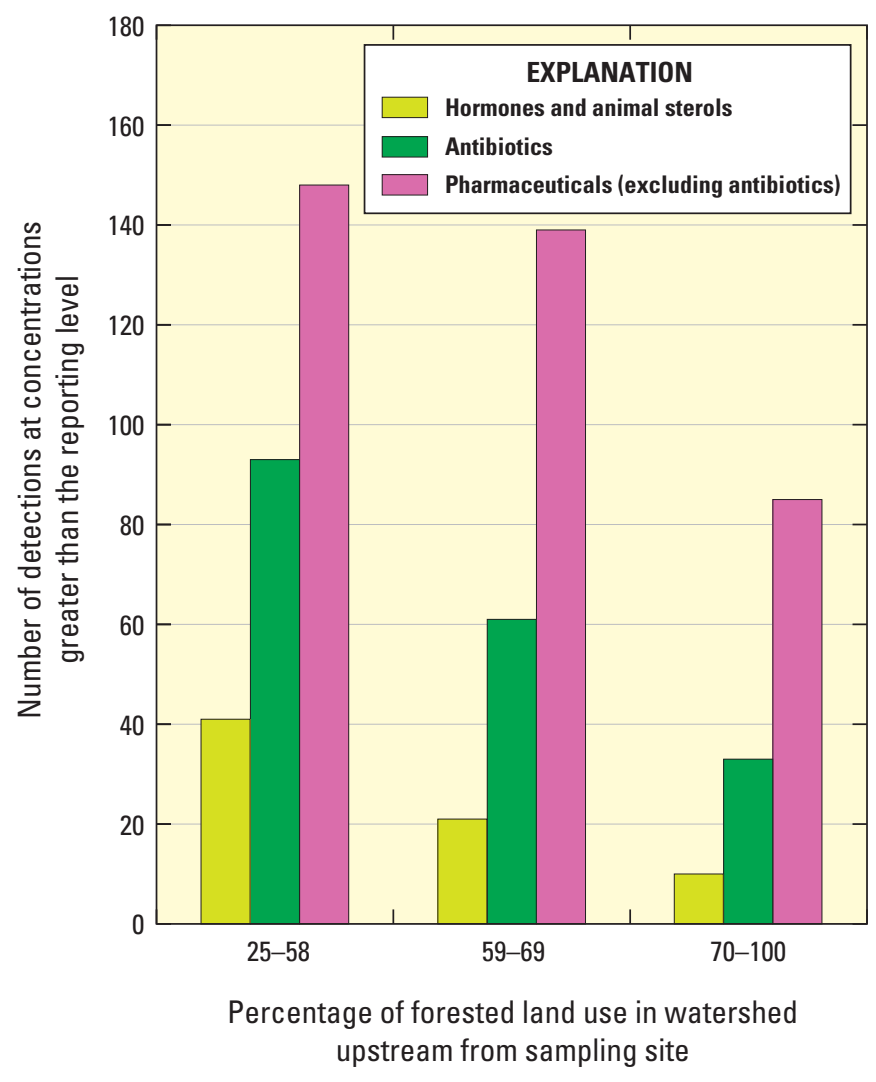

Figure 22. Number of detections of contaminants of emerging concern at concentrations greater than the reporting level in samples collected from 27 stream sites near drinking-water intakes by percentage of forested land use in Pennsylvania, 2007-09. upstream from the sampling site, and George Run had one permitted discharge upstream from the sampling site. These relatively undisturbed sites had the fewest number of contaminants of emerging concern. Schuylkill River (D4, 01474010), Beaver Creek (D27, 03107500), and Swatara Creek (D15, 01573560) were in the low category for percentages of forested land use and in the high category for the percentages of agricultural and urban land use (table 20). These three highly disturbed watersheds along with the Ohio River site (D24, 03086000) had the greatest number of total detections of the 27 sites sampled (fig. 23).

\section{Seasonal Variability}

The frequency of detection of contaminants of emerging concern throughout the year in streamwater may be the result of differences in concentrations at the source, the transport route that each compound takes to the stream, and variations in degradation within the stream. The rate of use for each contaminant may vary throughout the year. For example some pharmaceuticals may be used more in late fall through early spring during flu season, whereas others, such as hormones and those compounds used for chronic conditions like hypertension, would be expected to have consistent use and disposal rates. Also, pathways may be seasonally affected because sewage sludge and farm manure, for example, may be applied to fields in the spring and fall and uptake and runoff might vary during the growing season.

In general, the occurrence of contaminants of emerging concern did not vary consistently by season. Pharmaceutical (excluding antibiotics) and hormone detection frequencies were variable throughout the year. Antibiotic detection frequencies followed the seasonal flow patterns of detection frequencies, increasing during the summer and fall, which are seasons with low base flow (fig. 24).

Detection frequencies for the antibiotic sulfamethoxazole followed a pattern related to seasonal flow conditions. The lowest frequency of detection occurred during the high baseflow seasons (winter and spring), and the highest frequencies of detections occurred during the low base-flow seasons (summer and fall; fig. 25). The temporal variability in sulfamethoxazole occurrence does not indicate different seasonal use rates but rather a seasonal pattern related to dilution by streamflow. The detection frequency pattern of the analgesic acetaminophen was the opposite of the detection frequency pattern of sulfamethoxazole and the seasonal pattern. Acetaminophen was detected most frequently in winter ( 0.56 detections per sample); detection frequencies decreased through the spring and were lowest in the summer and fall (fig. 25). This pattern of detection may be the result of increased acetaminophen use in the winter, or degradation or sorption of the acetaminophen may be lower in cold water during the winter months when biological activity is decreased. 


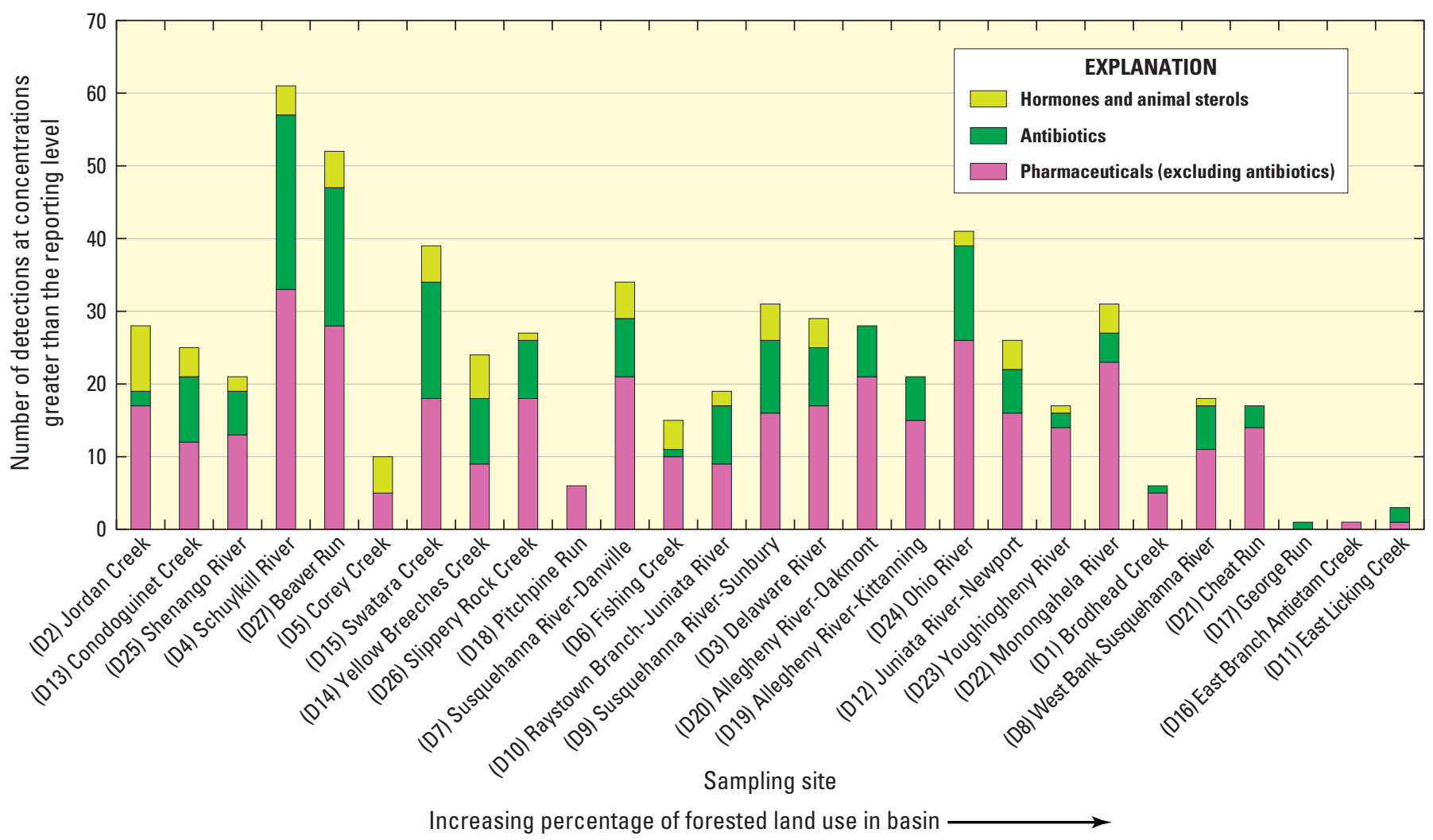

Figure 23. Number of detections of contaminants of emerging concern at concentrations greater than the reporting level in streamwater samples collected from 27 stream sites near drinking-water intakes in Pennsylvania, 2007-09.

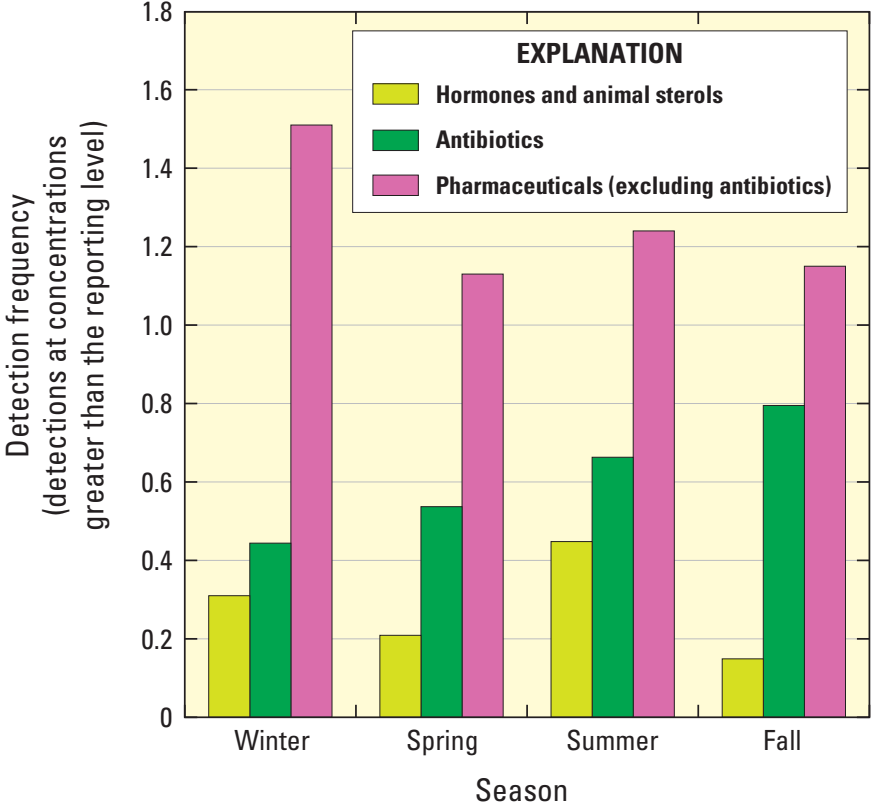

Figure 24. Detection frequency of contaminants of emerging concern, by season, in 297 streamwater samples collected from 27 stream sites near drinking-water intakes in Pennsylvania, 2007-09.

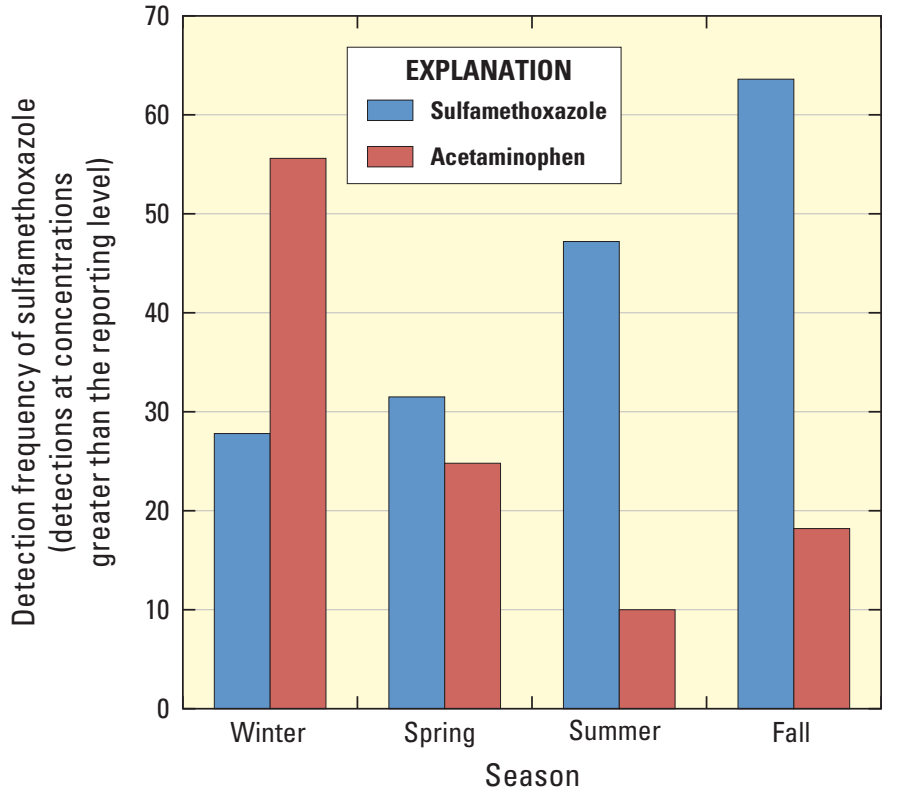

Figure 25. Detection frequency of sulfamethoxazole and acetaminophen, by season, in 297 streamwater samples collected from 27 stream sites near drinking-water intakes in Pennsylvania, 2007-09. 


\section{Compounds in Streamwaters and Streambed Sediment at Fish-Health Sites}

In 2007 and 2008, sampling was conducted to evaluate associations between contaminants of emerging concern and fish health. Three sites in the Delaware River Basin and eight sites in the Susquehanna River Basin were sampled in 2007, five sites in the Ohio River Basin were sampled in 2008 (table 8). Sites were selected upstream and downstream from potential sources of contaminants of emerging concern in watersheds of various sizes. Eleven of the 16 sites were collected at sites previously established as part of the drinkingwater intake reconnaissance sampling. One-time-only samples of streamwater and streambed sediments were collected from the 16 sites when the streams were at base-flow levels. Pharmaceuticals, hormones, and OWCs were analyzed in streamwater samples, and antibiotics, hormones, and OWCs were analyzed in streambed-sediment samples. Concurrent with streamwater and streambed-sediment sampling, fish were collected for morphological, histopathological, chemical, and molecular-biological examinations. The goal of this work was to determine whether contaminants of emerging concern contribute to declines in fish health. Only chemical data from the one-time-only samples collected in 2007 or 2008 are discussed.

\section{Compounds in Streamwater}

Forty-eight of the 119 (40 percent) contaminants of emerging concern were detected in streamwater at the 16 fish-health sites sampled in 2007 or 2008 (table 21, at end of report). Twenty-nine of the compounds were detected at least once at concentrations greater than the reporting levels and 19 were detected only at concentrations below the reporting levels. The compounds most frequently detected at concentrations greater than the reporting levels are caffeine (found in 81 percent of samples), the anticonvulsant drug carbamazepine (63 percent), the antibiotic sulfamethoxazole (63 percent), the natural estrogen estrone (56 percent), and the analgesic acetaminophen (31 percent). All other compounds were present at concentrations greater than the reporting levels in no more than 3 of the 16 samples collected. The most frequently detected compounds that are known or suspected endocrine disruptors were the pesticides 1,4-dichlorobenzene and metolachlor, the industrial compound benzophenone, and the flame retardants tri(2-chloroethyl)phosphate and tri(dichloroisopropyl)phosphate (Zaugg and others, 2002). The maximum concentration in streamwater samples of a known or suspected endocrine disruptor was $272 \mathrm{ng} / \mathrm{L}$ for the flame retardant tri(2-chloroethyl)phosphate. The concentrations of compounds detected in streamwater from the 16 fish health-sites ranged from $0.2 \mathrm{ng} / \mathrm{L}$ for the natural estrogen estriol to $604 \mathrm{ng} / \mathrm{L}$ for the flame retardant tri(2-butoxyethyl) phosphate. Hormones had the lowest detected concentrations (0.2-2.7 ng/L), and OWCs had the highest concentrations (2-604 ng/L).

In general, the number of compounds detected at any particular site was low (fig. 26). The maximum number of detections at any site was eight, which occurred for Schuylkill River at Philadelphia (F1, 01474010), Brodhead Creek at Minisink Hills (F6, 01442500), and Swatara Creek at Harper Tavern (F7, 01573000, fig. 27). The Schuylkill River and Brodhead Creek sites are both affected by wastewater-effluent discharge. None of the contaminants of emerging concern were detected in the sample from the Brodhead Creek near East Stroudsburg (F5, 01440650) (fig. 27). This site is upstream from the towns of Stroudsburg and East Stroudsburg and in a largely forested watershed (78 percent forested). The concentration ranges for samples from the 16 fish-health sites were generally lower than those for samples collected downstream from wastewater-effluent discharges and were similar to those for samples collected near drinking-water intakes (table 22).

\section{Compounds in Streambed Sediment}

A single streambed-sediment sample was collected at each of the 16 fish-health sites (table 7) in 2007 or 2008 and analyzed for antibiotics, hormones, and OWCs. Thirty-six of the 98 (37 percent) contaminants of emerging concern were detected at the 16 fish-health sites sampled in 2007 or 2008 (table 21). All of the 36 compounds were detected at least once at concentrations greater than their reporting level. The most frequently detected compounds in streambed-sediment samples were the OWCs phenanthrene and pyrene, which were detected in all 16 samples, and benzo[a]pyrene and fluoranthene, which were detected in 15 of 16 samples (table 21). Benzo[a]pyrene, para-cresol, and 17-beta-estradiol were the most frequently detected OWCs that are known or suspected endocrine disruptors (Zaugg and others, 2002). Benzo[a] pyrene was detected at concentrations greater than the reporting level in 94 percent of streambed-sediment samples with a maximum concentration of $801 \mu \mathrm{g} / \mathrm{kg}$, and para-cresol was detected at concentrations greater than the reporting level in 38 percent of streambed-sediment samples with a maximum concentration of $2,450 \mu \mathrm{g} / \mathrm{kg}$. Four of the 27 antibiotic compounds and 7 of the 17 hormones and 2 animal sterols analyzed were detected. Ofloxacin was the most frequently detected antibiotic (50 percent), and estrone was the most frequently detected hormone ( 75 percent). The maximum number of detections in streambed-sediment samples of contaminants of emerging concern at concentrations greater than the reporting level at any one site was 25 for Swatara Creek near Hummelstown (F9, 01573583). Brodhead Creek at Minisink Hills (F6, 01442500) had the fewest (6) detections of contaminants of emerging concern (fig. 28). 

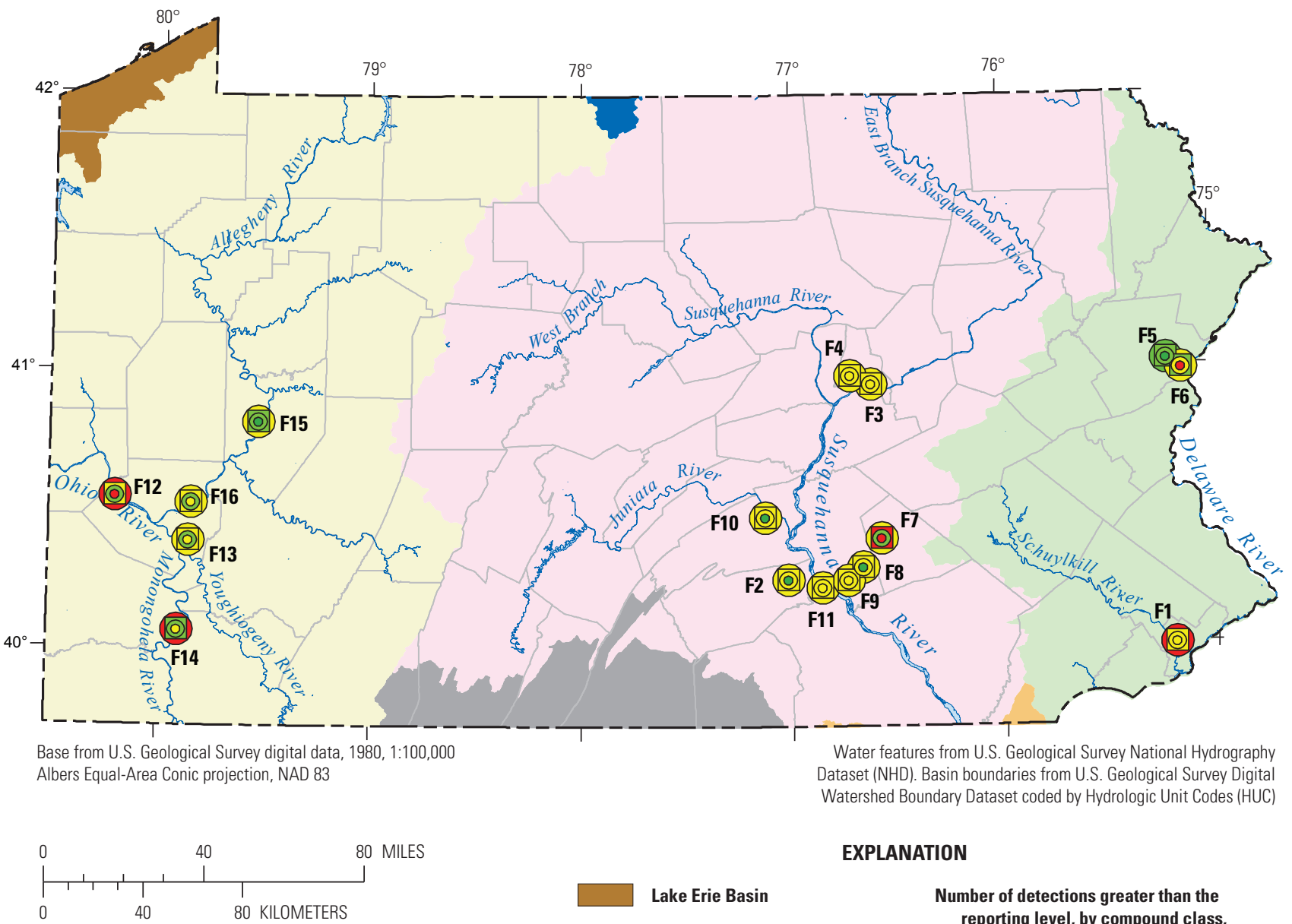

\section{EXPLANATION}

Lake Erie Basin

Ohio River Basin

Genesee River Basin

Potomac River Basin

Susquehanna River Basin

Chesapeake Bay Basin

Delaware River Basin
Number of detections greater than the reporting level, by compound class for fish-health sampling sites

Wastewater compounds

00

○ $1-2$

- 3-6 Hormones

0

1-2

Antibiotics

$\square \quad 0$

$\square \quad 1-2$

$\square 3$

Pharmaceuticals

$\bigcap^{1-2} 3$

Figure 26. Location of fish-health sites sampled with the number of total detections greater than the reporting level, by compound class, in Pennsylvania, 2007 or 2008. 


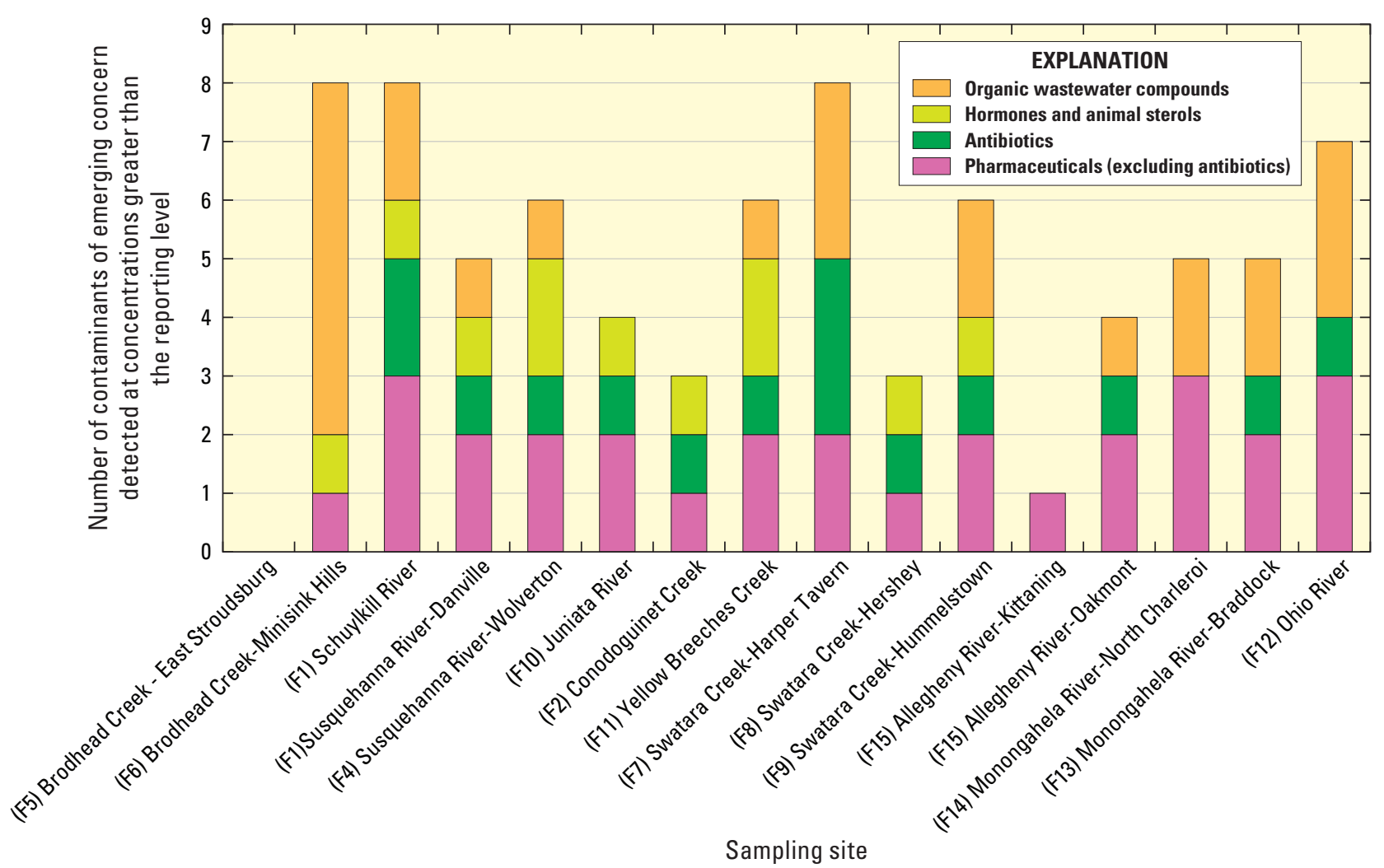

Figure 27. Number of contaminants of emerging concern detected at concentrations greater than the reporting level in streamwater samples collected at 16 fish-health sites in Pennsylvania, 2007 or 2008. 
Table 22. Detection frequencies of selected compounds in samples collected from sites downstream from wastewater-effluent-discharge sites, 2007-09; sites near drinking-water intakes, 2007-09; and fish-health sites, 2007 and 2008, in Pennsylvania.

[ng/L, nanograms per liter]

\begin{tabular}{|c|c|c|c|c|c|}
\hline Compound & $\begin{array}{l}\text { Number of } \\
\text { analyses }\end{array}$ & $\begin{array}{l}\text { Number of } \\
\text { detections at } \\
\text { concentrations } \\
\text { greater than } \\
\text { reporting level }\end{array}$ & $\begin{array}{c}\text { Number of } \\
\text { detections at } \\
\text { concentrations } \\
\text { less than } \\
\text { reporting level }\end{array}$ & $\begin{array}{c}\text { Percent } \\
\text { detections } \\
\text { at any } \\
\text { concentration }\end{array}$ & $\begin{array}{c}\text { Concentration } \\
\text { range } \\
\text { (ng/L) }\end{array}$ \\
\hline \multicolumn{6}{|c|}{ Sites located downstream from wastewater-effluent-discharge sites (2007-2009) } \\
\hline Carbamazepine & 24 & 21 & 0 & 87 & $15-212$ \\
\hline Diphenhydramine & 24 & 11 & 3 & 58 & $3-85$ \\
\hline Sulfamethoxazole & 24 & 24 & 0 & 100 & $5-1,150$ \\
\hline Trimethoprim & 24 & 18 & 0 & 75 & $6-704$ \\
\hline Estrone & 24 & 12 & 0 & 50 & $0.6-25$ \\
\hline \multicolumn{6}{|c|}{ Sites located near drinking-water intakes (2007-2009) } \\
\hline Carbamazepine & 297 & 61 & 36 & 33 & $1-95$ \\
\hline Diphenhydramine & 297 & 0 & 20 & 7 & $1-6$ \\
\hline Sulfamethoxazole & 294 & 119 & 0 & 40 & $5-146$ \\
\hline Trimethoprim & 294 & 23 & 0 & 8 & $5-18$ \\
\hline Estrone & 270 & 48 & 3 & 19 & $0.3-3.1$ \\
\hline \multicolumn{6}{|c|}{ Fish-health sites (2007 and 2008) } \\
\hline Carbamazepine & 16 & 10 & 3 & 81 & $3-64$ \\
\hline Diphenhydramine & 16 & 0 & 0 & 0 & 0 \\
\hline Sulfamethoxazole & 16 & 10 & 0 & 62 & $7-101$ \\
\hline Trimethoprim & 16 & 1 & 0 & 6 & 12 \\
\hline Estrone & 16 & 9 & 1 & 62 & $0.3-2.72$ \\
\hline
\end{tabular}




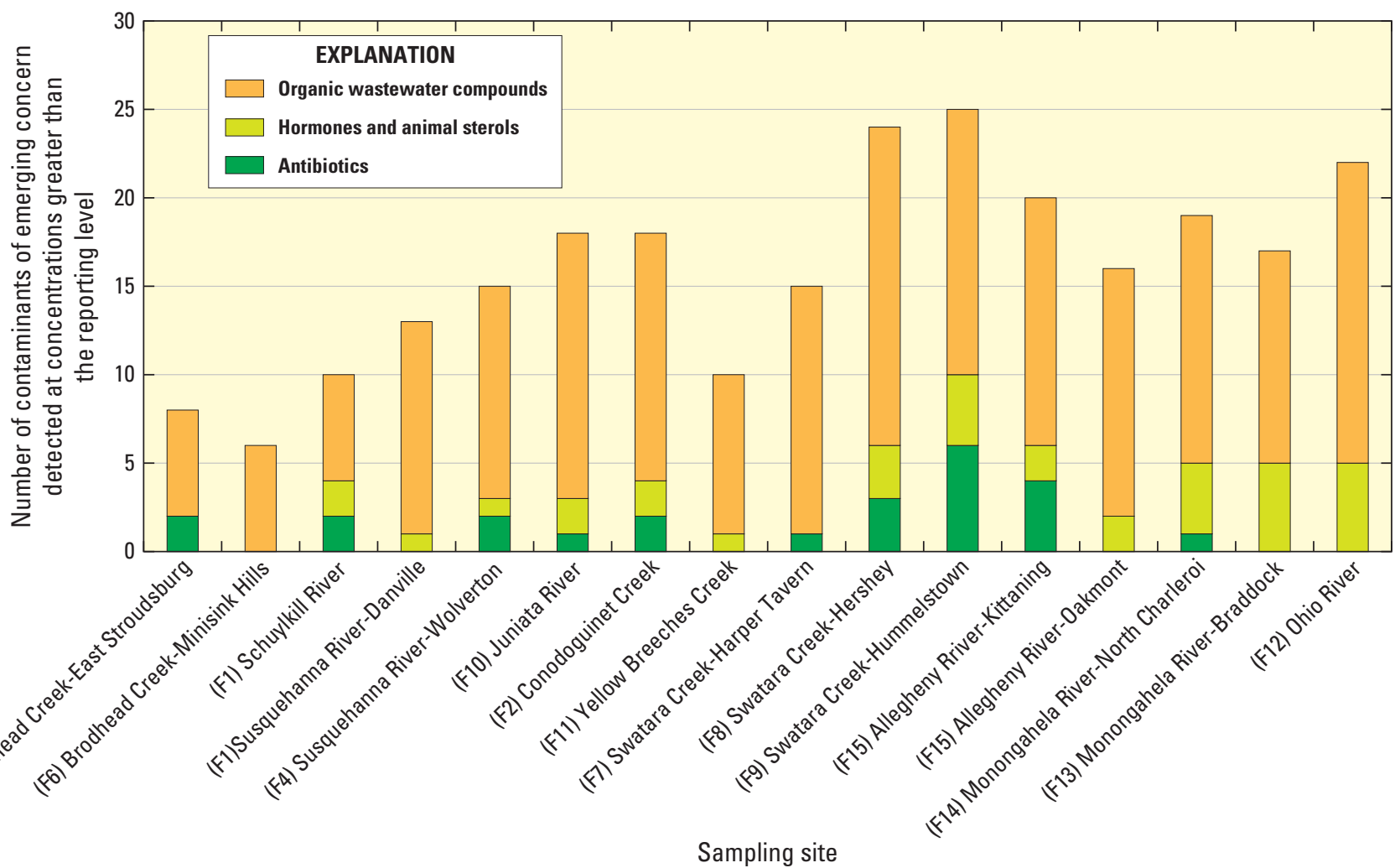

Figure 28. Number of contaminants of emerging concern detected at concentrations greater than the reporting level in streambedsediment samples from 16 fish-health sites sampled in Pennsylvania, 2007 or 2008. 


\section{Implications of Contaminants of Emerging Concern in Pennsylvania Waters}

Water-quality standards have not been established for the contaminants of emerging concern considered in this study. Therefore, it is difficult to quantitatively evaluate the effects of these compounds. Yet, a body of literature is growing that can help in understanding the likely implications of the presence of these compounds in streamwater and streambed sediment. In this section of the report, data collected for this study are evaluated in light of existing scientific literature.

\section{Implications for Ecosystem Health}

The contaminants of emerging concern detected in this study were measured at low levels with concentrations in nanograms per liter in streamwater. Even at low concentrations, the effects on aquatic organisms of constant exposure, long-term exposure, and exposure to a mix of chemicals are largely unknown (Daughton and Ternes, 1999; Jorgensen and Halling-Sorensen, 2000). Water-quality criteria for the protection of aquatic life have not been established for the compounds studied, so there are no benchmarks by which to judge the concentrations measured. But, these chemicals may pose a risk because they were developed to be stable and to trigger specific biological effects at low doses. Further, many of the contaminants of emerging concern in question are disposed of or discharged to the environment continuously, which results in lifetime exposure of organisms to some compounds (Daughton and Ternes, 1999; Monteiro and Boxall, 2010).

Further evidence of population effects on fish was found during a 7-year-long Canadian study (Kidd and others, $2007)$ in which a lake was dosed with low levels $(5 \mathrm{ng} / \mathrm{L})$ of 17-alpha-ethynylestradiol over a 3-year period. Male fathead minnows (Pimephales promelas) in the lake developed increased levels of vitellogenin messenger ribonucleic acid (RNA) and protein (associated with oocyte maturation in females) and early-stage eggs in their testes, whereas fish in two control lakes did not. Reproductive failure occurred in the dosed lake, and the fish population declined dramatically. The population remained healthy in the control lakes. The fathead minnow population in the dosed lake recovered once the 17-alpha-ethynylestradiol dosing was terminated. "The results from this whole lake experiment demonstrate that continued inputs of natural and synthetic estrogens and estrogen mimics...could decrease the reproductive success and sustainability of fish populations" (Kidd and others, 2007). In the present study, the highest concentrations for most of the hormones were measured at sites downstream from wastewater-effluentdischarge sites. The hormone 17-alpha-ethynylestradiol was not found in any water samples and was detected only twice in the streambed-sediment samples at a maximum concentration of $1.7 \mu \mathrm{g} / \mathrm{kg}$.
Thorpe and others (2003) determined in laboratory studies that plasma vitellogenin response can be induced in rainbow trout at 17-beta-estradiol concentrations as low as $5 \mathrm{ng} / \mathrm{L}$. Vajda and others (2008) found several indicators of reproductive disruption in Boulder Creek, Colorado, downstream from a wastewater-effluent-discharge site. Concentrations of 17-beta-estradiol at this site were about $2 \mathrm{ng} / \mathrm{L}$. The highest concentrations of 17-beta-estradiol measured in the present study were $0.9 \mathrm{ng} / \mathrm{L}$ in a streamwater sample and $1.9 \mu \mathrm{g} / \mathrm{kg}$ in a streambed-sediment sample.

The body of evidence in the scientific literature is building that estrogenic compounds can act together to produce reproductive effects in fish (Thorpe and others, 2003; Brian and others, 2005; Kortenkamp, 2007). Some researchers (Brian and others, 2005) have demonstrated that the effects of several compounds in the estrogen family are additive. Others researchers have argued for expressing effects in terms of estradiol equivalents (Thorpe and others, 2006). Thus, concentrations of individual estrogen compounds may not be as revealing as the total concentration or the estradiol-equivalent concentration of the compounds present. The results from the present study indicate that concentrations of estrogen-related compounds are greatest at sites downstream from wastewater-effluent discharges; however detections of individual compounds were rare, and concentrations were below levels reported to cause physiological and reproductive issues in fish.

In the Susquehanna River in Pennsylvania, populations of smallmouth bass (Micropterus dolomieu) have been declining during the past 5 years (2007-2011). Annual surveys of young-of-the-year smallmouth bass conducted by the Pennsylvania Fish and Boat Commission have documented that many of the young fish are in moribund condition and have bacterial infections (Chaplin and others, 2009). Conclusions on causative factors have not been reached, although contaminants of emerging concern have been suggested as one possible cause because they may act as immunosuppressors. Research in other rivers indicated that if the immune system of the fish is compromised, the fish may be infected by the ubiquitous bacteria that are ever-present in the stream (Ripley and others, 2008; Robertson and others, 2009).

Another line of thinking regarding the decline of smallmouth bass populations in the Susquehanna River is that exposure to estrogenic compounds may disrupt endocrine functioning in the fish. The reconnaissance studies were not designed to investigate Susquehanna River smallmouth bass issues, but the limited data do not indicate the presence of estrogenic or endocrine disrupting compounds in higher concentrations at the sampling sites in the Susquehanna River Basin than at sites in the Delaware River Basin. However, water samples from the Susquehanna River Basin had consistently higher concentrations of estrogenic compounds than samples from the Ohio River Basin where no hormones were detected in water samples. The hypotheses for the decline in smallmouth bass populations in the Susquehanna River Basin are associated with little experimental evidence and, therefore, are likely to be adjusted as more information becomes available. 


\section{Implications for Contaminants in Source Waters for Public Drinking-Water Supplies}

The effectiveness of conventional drinking-water-treatment processes can vary widely within and among different classes of compounds. Studies of finished drinking-water supplies indicate that the removal of contaminants of emerging concern through the drinking-water-treatment process is incomplete. Pharmaceutical compounds, such as acetaminophen, caffeine, and carbamazepine, along with OWCs such as DEET, AHTN, and camphor, have been frequently found in finished drinking-water supplies and may be a source of human exposure (Stackelberg and others, 2007). Groundwater used for household drinking-water supply, which may be susceptible to contamination from on-lot sewage disposal, often receives no treatment or less treatment than surface water used as a source of drinking-water supply and, therefore, may also represent threats to public health. Drinking-water standards have not been established for these individual compounds or mixtures of these compounds; therefore, the potential health risk is not known. However, some studies indicate that there is a low risk to human health (Webb and others, 2003; Schwab and others, 2005). These findings are based on limited knowledge about the chronic effects of low-dose exposure to a mixture of compounds, and the findings do not rule out the possibility of negative effects on human health.

Although pharmaceutical compounds were detected in drinking water, exposure was very small in comparison to the amount that is voluntarily ingested or applied to the body. For humans who do not spend a lifetime submerged in water containing these trace compounds, concentrations are substantially below the levels currently associated with adverse health effects. For several compounds detected at trace concentrations, thousands of liters of water per day would need to be consumed to meet the effective daily intake dose for that compound (Snyder and others, 2009).

The highest concentration of acetaminophen measured in a streamwater sample in this study was $210 \mathrm{ng} / \mathrm{L}$. A typical, voluntarily ingested, human dose of acetaminophen is $500 \mathrm{mg}$, which is approximately 2.3 million times the highest concentration measured in this study. For carbamazepine, the highest concentration measured in this study was $276 \mathrm{ng} / \mathrm{L}$ in a streamwater sample collected downstream from a wastewatereffluent-discharge site. A typical daily dose of carbamazepine is $400 \mathrm{mg}$ (U.S. Food and Drug Administration, 2005). So, the daily medical dose is about 1.5 million times the amount of carbamazepine in a liter of water measured in the present study.

Many conventional and advanced treatment processes reduce the concentration of some of these compounds in drinking water (Stackelberg and others, 2004; Stackelberg and others, 2007; Huerta-Fontela and others, 2008; Snyder and others, 2008; Benotti and others, 2009). Removal depends greatly on the structure and concentration of the compound. It has been shown that estrogenic compounds are degraded by chlorine, the principal chemical used in many water-treatment processes. Ozone is much more effective than chlorine and can remove a substantial amount of most of the target analytes. Other technologies proven effective in reducing estrogenicity include Granular Activated Carbon (GAC) and Nanofiltration/ Reverse Osmosis (NF/RO) (Snyder and others, 2008).

A potential human-health implication resulting from the abundance of antibiotics entering the environment is the emergence of antibiotic resistant bacteria (Fogarty and others, 2007). Antibiotic resistance in the environment may result from the application to land of antibiotics in wastewatertreatment-plant biosolids or manure from livestock operations that intensely use antibiotics. Research has also shown that not all antibiotic resistance is caused by direct use of antibiotics; other variables may include heavy metals. Ecological interactions among soil microbes could also play a role (Wohl and Bowne, 2008).

\section{Summary}

Reconnaissance sampling for contaminants of emerging concern in Pennsylvania groundwater, streamwater, and streambed sediment was conducted during a 4-year period, 2006 to 2009, by the U.S. Geological Survey (USGS), in cooperation with the Pennsylvania Department of Environmental Protection. The contaminants considered include pharmaceutical compounds, hormones, and organic wastewater compounds (OWCs). The multicomponent study evaluated contaminants of emerging concern in (1) groundwater from wells used to supply livestock, (2) streamwater upstream and downstream from animal-feeding operations, (3) streamwater upstream from and streamwater and streambed sediments downstream from municipal wastewater-effluent discharges, (4) streams within 5 miles of drinking-water intakes, and (5) streams where additional studies of fish health were being conducted. The wells and stream sites sampled upstream and downstream from animal-feeding operations and wastewatereffluent-discharge sites (first three components of the study) are located in south-central Pennsylvania, and the fish-heath and drinking-water stream sites are located statewide. The stream sites in south-central Pennsylvania, in general, were sampled under base-flow conditions three or more times for 1 to 3 years, and statewide sites near drinking-water intakes were sampled quarterly for 3 years under a range of hydrologic conditions. Reconnaissance sampling was conducted from 2006 to 2009 with a limited number of sites and limited number of samples collected for the investigation of suspected sources of contaminants of emerging concern.

Detections of pharmaceutical compounds in water samples collected from wells in agricultural areas and streamwater samples upstream and downstream from animal-feeding operations were rare. Many of the compounds detected in 
these samples were not veterinary-use compounds, but humanuse compounds. This finding indicates that agricultural land use and animal-feeding operations were not a major source of pharmaceuticals.

A greater number of contaminants of emerging concern were detected at higher detection frequencies and at greater concentrations in samples from sites downstream from a municipal wastewater-effluent-discharge site than in samples from sites upstream from a municipal wastewater-effluentdischarge site. For the sites downstream from wastewatereffluent discharges, the most commonly detected contaminants in streamwater samples were carbamazepine (anticonvulsant), sulfamethoxazole (antibiotic), and tri(dichloroisopropyl)phosphate (flame retardant). The contaminants most commonly detected in streambed-sediment samples collected downstream from wastewater-effluent discharges were the antibiotics ofloxacin and trimethoprim, the natural estrogen estrone, and the polycyclic aromatic hydrocarbons benzo[a]pyrene, fluoranthene, phenanthrene, and pyrene. This finding confirms the finding of other researchers, which is that wastewater effluents constitute a source of these compounds.

Compounds with known or suspected endocrine disrupting potential were detected in both streamwater and streambed-sediment samples. Although samples collected downstream from a municipal wastewater-effluent-discharge site contained the most compounds detected and highest concentrations detected, samples without a wastewater-effluent discharge or sites distant from a wastewater-effluent-discharge site also had detectable concentrations of contaminants of emerging concern. Nonpoint sources of contamination may include on-lot septic systems, combined sewer overflows, and agricultural land use.

Results from this study identified Killinger Creek as the sampling site with the greatest number of contaminants of emerging concern detected and at the greatest concentrations. Streams like Killinger Creek, in which the wastewater-effluent discharge constitutes a large percentage of the total streamflow, are more likely to have a higher number of compounds detected at higher concentrations than streams without wastewater-effluent discharge because of a lack of dilution of the wastewater effluent.

Twenty-one of the 63 contaminants of emerging concern analyzed were detected one or more times at concentrations greater than their reporting levels in samples collected at 27 stream sites near drinking-water intakes in Pennsylvania from 2007 to 2009. The 10 most frequently detected compounds represent a wide variety of uses, but all were derived from human sources. None of the most commonly detected compounds are typically used in agricultural operations. This finding indicates that most of the contaminants of emerging concern detected near the 27 drinking-water intake sites entered the stream environment via municipal wastewater-treatment effluent or on-lot septic systems.

Measured concentrations of contaminants of emerging concern at the stream sites near drinking-water intakes generally were very low (generally less than 100 nanograms per liter). These compounds do not have established guidelines. Most of the compounds analyzed were never or rarely detected. Forty-two of the 63 compounds were never detected at concentrations greater than their reporting level, and only 8 compounds were detected in more than 5 percent of the samples analyzed. The most commonly detected compounds were caffeine; the pharmaceutical compounds acetaminophen, carbamazepine, sulfamethoxazole, and trimethoprim; and the hormone estrone. All concentrations of pharmaceutical compounds measured at the sites near drinking-water intakes were within the range of concentrations reported in a national reconnaissance of sites near drinking-water sources. The compounds frequently detected near the 27 drinkingwater intake sites also were the same as those previously reported in another national reconnaissance.

The major factors that appear to affect the detection of contaminants of emerging concern at the 27 stream sites located near drinking-water intakes are related to wastewater sources, land use, and in-stream dilution. Samples from sites in watersheds with a large number of wastewater discharges and a high percentage of non-forested land had the greatest number of detections of pharmaceutical compounds and hormones. This finding supports the hypothesis that the largest inputs of contaminants of emerging concern are most likely from wastewater-effluent discharge. At individual sampling sites, the largest concentrations and greatest number of detections typically occurred at times of low streamflow when contaminants are most concentrated, although at least one compound, acetaminophen, did not follow this pattern.

The sites near drinking-water intakes that had greatest number of detections of contaminants of emerging concern were generally on mid-sized to large rivers with mixed urban and agricultural land use and a large number of discharges per unit of drainage area. Sites on the Schuylkill River, Beaver River, Ohio River, and Swatara Creek are associated with more than 20 detections of contaminants of emerging concern during 2007-09. Sites with the fewest numbers of detections of contaminants of emerging concern were generally on small- to mid-size streams in heavily forested watersheds with few point discharges. Brodhead Creek, East Licking Creek, East Branch Antietam Creek, George Run, and Pitchpine Run had less than three detections of contaminants per site.

Unlike fish and other aquatic organisms, humans are not in contact with water at all times. Human exposure to contaminants of emerging concern is likely to be primarily through ingestion. The drinking-water sources examined in the present study contained a mix of a few targeted contaminants of emerging concern. However, those contaminants were measured in low concentrations, many times lower than a typical human pharmaceutical dose. Acute effects on human health or aquatic biota arising from contaminants of emerging concern appear limited because of the low concentrations detected in the environment. Subtle, chronic effects on aquatic biota as a result of constant low-level environmental exposure are possible. 
Detection frequencies of contaminants of emerging concern for samples from 16 fish-health sites were generally low and were similar to those for samples from sites near drinkingwater intakes. Concentrations of the detected contaminants were below levels reported to cause physiological and reproductive issues in fish.

Contaminants of emerging concern were found more frequently in the streambed-sediment samples than in streamwater samples. Antibiotic compounds were often found in both streamwater and streambed-sediment samples, but many organic wastewater compounds were found exclusively in the streambed-sediment samples.

Compounds with known or suspected endocrine disrupting potential were detected in streamwater and streambedsediment samples. Detection of these compounds was rare in samples collected at sites distant from wastewater-effluent discharge. Sites directly affected by a wastewater-effluent discharge were associated with greater detection frequencies and higher concentrations of compounds with known or suspected endocrine disrupting potential. Flame retardant and pesticide compounds were more likely to be detected in streamwater, and polycyclic aromatic hydrocarbons and detergent metabolites were more likely to be detected in streambed-sediment samples.

\section{References Cited}

Alvarez, D.A., Cranor, W.L., Perkins, S.D., Schroeder, V.L., Werner, S.L., Furlong, E.T., Kain, D., and Brent, R., 2008, Reconnaissance of persistent and contaminants of emerging concern in the Shenandoah and James River Basins, Virginia, during Spring of 2007: U.S. Geological Survey Open-File Report 2008-1231, 19 p.

American Chemical Society, 2010, Chemical Abstracts Service, A Division of the American Chemical Society, CAS Registry, accessed July 29, 2010, at http://www.cas.org/.

Barnes, K.K., Christenson, S.C., Kolpin, D.W., Focazio, M.J., Furlong, E.T., Zaugg, S.D., Meyer, M.T., and Barber, L.B., 2004, Pharmaceuticals and other organic waste water contaminants within a leachate plume downgradient of a municipal landfill: Ground Water Monitoring and Remediation, v. 24, no. 2, p. 119-126.

Barnes, K.K., Kolpin, D.W., Furlong, E.T., Zaugg, S.D., Meyer, M.T., and Barber, L.B., 2008, A national reconnaissance of pharmaceuticals and other organic wastewater contaminants in the United States: Groundwater: Science of the Total Environment, v. 402, issues 2-3, September 2008, p. 192-200.

Benotti, M.J., Trenholm, R.A., Vanderford, B.J., Holady, J.C., Stanford, B.J., and Snyder, S.A., 2009, Pharmaceuticals and endocrine disrupting compounds in U.S. drinking water: Environmental Science and Technology, v. 43, no. 3, p. 597-603.

Blazer, V.S., Iwanowicz, L.R., Iwanowicz, D.D., Smith, D.R., Young, J.A., Hedrick, J.D., Foster, S.W., and Reeser, S.J., 2007, Intersex (testicular oocytes) in smallmouth bass from the Potomac River and selected nearby drainages: Journal of Aquatic Animal Health, v. 19, p. 242-253.

Boxall, A.B.A, Johnson, P., Smith, E.J., Sinclair, C.J., Stutt, E., and Levy, L.S. 2006, Uptake of veterinary medicines from soils into plants: Journal of Agricultural and Food Chemistry, v. 54, p. 2288-2297.

Brian, J.V., Harris, C.A., Scholze, Martin, Backhaus, Thomas, Booy, Petra, Lamoree, Marja, Pojana, Giulio, Jonkers, Niels, Runnalls, Tasmin, Bonfa, Angela, Marcomini, Antonio, and Sumpter, J.P., 2005, Accurate prediction of the response of freshwater fish to a mixture of estrogenic chemicals: Environmental Health Perspectives, v. 113, no. 6 , p. 721-728.

Burkhart, M.R., Zaugg, S.D., Smith, S.G., and ReVello, R.C., 2006, Determination of wastewater compounds in sediment and soil by pressurized solvent extraction, solid-phase extraction, and capillary-column gas chromatography/ mass spectrometry: U.S. Geological Survey Techniques and Methods 2-B2, 3-40 p. 
Cahill, J.D., Furlong, E.T., Burkhardt, M.R., Kolpin, D.W., and Anderson, L.G., 2004, Determination of pharmaceutical compounds in surface- and well-water samples by solidphase extraction and high-performance liquid chromatography/electrospray ionization mass spectrometry: Journal of Chromatography A, v. 1041, p 171-180.

Carrara, Cherilyn, Ptacek, C.J., Robertson, W.D., Blowes, D.W., Moncur, M.C., Sverko, Ed, and Backus, Sean, 2008, Fate of pharmaceutical and trace organic compounds in three septic system plumes, Ontario, Canada: Environmental Science and Technology, v. 42, no. 8, p. 2805-2811.

Chambers, D.B., and Leiker, T.J., 2006, A reconnaissance for contaminants of emerging concern in the South Branch Potomac River, Cacapon River, and Williams River Basins, West Virginia, April-October, 2004: U.S. Geological Survey Open-File Report 2006-1393, 23 p.

Chaplin, J.J., Crawford, J.K., and Brightbill, R.A., 2009, Water-quality monitoring in response to young-of-the-year smallmouth bass in the Susquehanna River and major tributaries, Pennsylvania: 2008: U.S. Geological Survey OpenFile Report 2009-1216, 59 p.

Childress, C.J.O., Foreman, W.T., Connor, B.F., and Maloney, T.J., 1999, New reporting procedures based on longterm method detection levels and some considerations for interpretations of water-quality data provided by the U.S. Geological Survey National Water Quality Laboratory: U.S. Geological Survey Open-File Report 99-193, 19 p.

Couper, F.J., and Logan, B.K., 2004, Drugs and human performance fact sheet: Washington, D.C., National Highway Traffic Safety Administration, DOT HS 809725.

Damschen, W.C., and Lundgren, R.F., 2009, Occurrence of contaminants of emerging concern in water and bed material in the Missouri River, North Dakota, 2007: U.S. Geological Survey Fact Sheet 2008-3007, 3 p.

Daughton, C.G., and Ternes, T.A., 1999, Pharmaceuticals and personal care products in the environment: agents of subtle change?: Environmental Health Perspectives. v. 107, supplement 6, p. 907-938.

Focazio, M.J., Kolpin, D.W, Barnes, K.K., Furlong, E.T., Meyer, M.T., Zaugg, S.D., Barber, L.B., and Thurman, M.E., 2008, A national reconnaissance for pharmaceuticals and other organic wastewater contaminants in the United States II Untreated drinking water sources: Science of the Total Environment, v. 402, p. 201-216.

Fogarty, L.R., Duris, J.W., Crowley, S.L., Hardigan, N., 2007, Antibiotic-resistent fecal bacteria, antibiotics, and mercury in surface waters of Oakland County, Michigan, 2005-2006: U.S. Geological Survey Scientific Investigations Report 2007-5242, 30 p.
Fono, L.J., Kolodziej, E.P., and Sedlak, D.L., 2006, Attenuation of wastewater-derived contaminants in an effluentdominated river: Environmental Science and Technology, v. 36 , no. 6 , p. $7257-7262$.

Furlong, E.T., Werner, S.L., Anderson, B.D., Cahill, J.D., 2008, Determination of human-health pharmaceuticals in filtered water by chemically modified styrene-divinylbenzene resin-based solid-phase extraction and highperformance liquid chromatography/mass spectrometry: U.S. Geological Survey Techniques and Methods 5-B5, $56 \mathrm{p}$.

Gannett Fleming, 2009, Borough of Palmyra 2008 municipal wasteload management report: Palmyra Annual Services Article 1\2009\003 Chapter 94\2008 Report, 9 p.

Glassmeyer, S.T., Furlong, E.T., Kolpin, D.W., Cahil, J.D., Zaugg, S.D., Werner, S.L., Meyer, M.T., and Kryak, D.D., 2005, Transport of chemical and microbial compounds from known wastewater discharges: potential for use as indicators of human fecal contamination: Environmental Science and Technology, v. 39, p. 5157-5169.

Haack, S.K., 2009, Antibiotic, pharmaceutical, and wastewater-compound data for Michigan, 1998-2005: U.S. Geological Survey Scientific Investigations Report 2009-5217, $36 \mathrm{p}$.

Hall, J.E., 2011, Guyton and Hall textbook of medical physiology (12th ed.): Philadelphia, Pa., Saunders/Elsevier, $1,120 \mathrm{p}$.

Halling-Sorensen, B., Nors Nielsen, S., Lansky, P.F., Ingerslev, F., Holten Lutzhoft, H.C., and Jorgensen, S.E., 1998, Occurrence, fate, and effects of pharmaceutical substances in the environment-A review: Chemosphere, v. 36, no. 2, p. 357-393.

Hinck, J.E., Blazer, V.S., Denslow, N.D., Gross, T.S., Echols, K.R., Davis, A.P., May, T.W., Orazio, C.E., Coyle, J.J., and Tillit, D.E., 2006, Biomonitoring of environmental status and trends program-Environmental contaminants, health indicators, and reproductive biomarkers in fish from the Colorado River Basin: U.S. Geological Survey Scientific Investigations Report 2006-5163, 119 p.

Homer, C., Huang, C., Yang, L., Wylie, B. and Coan, M., 2004. Development of a 2001 National Land Cover Database for the United States: Photogrammetric Engineering and Remote Sensing, v. 70, no. 7, p. $829-840$.

Huerta-Fontela, M., Galceran, M.T., and Ventura, Francesc, 2008, Stimulatory drugs of abuse in surface waters and their removal in a conventional drinking water treatment plant; Environmental Science and Technology, v. 42, no. 18, p. 6809-6816. 
Iguchi, T., Watanabe, H., and Katsu, Y., 2001, Developmental effects of estrogenic agents on mice, fish and frogs: a mini review: Hormonal Behavior, v. 40, no. 2, p. 248-251.

Jobling, S., Williams, R., Johnson, A., Taylor, A., GrossSorokin, M., and Nolan, M., Tyler, C.R., van Aerle, R., Santos, E., and Brighty, G., 2006, Predicted exposures to steroid estrogens in U.K. rivers correlate with widespread sexual disruption in wild fish populations: Environmental Health Perspectives, v. 114 (Supplement 1), p. 32-39.

Jobling, S., Burn, R.W., Thorpe, K., Williams, R., and Tyler, C., 2009, Statistical modeling suggests that antiandrogens in effluents from wastewater treatment works contribute to widespread sexual disruption in fish living in English rivers: Environmental Health Perspectives, v. 117, no. 5, p. 797-802.

Jorgensen, S.E., and Halling-Sorensen, B., 2000, Drugs in the environment; Chemosphere, v. 40, no. 7, p. 691-699.

Khan, S.J., and Ongerth, J.E., 2002, Estimation of pharmaceutical residues in primary and secondary sewage sludge based on quantities of use and fugacity modeling: Water Science and Technology, v. 46, no. 3, p. 105-113.

Kidd, K.A., Blanchfield, P.J., Mills, K.H., Palace, V.P., Evans, R.E., Lazorchak, J.M., and Flick, R.W., 2007, Collapse of a fish population after exposure to a synthetic estrogen: Proceedings of the National Academy of Sciences, v. 104, no. 21, p. 8897-8901.

Kinney, C.A., Fulong, E.T., Zaugg, S.D., Burkhardt, M.R., Werner, S.L., Cahill, J.D., and Jorgensen, G.R., 2006, Survey of organic wastewater contaminants in biosolids destined for land application: Environmental Science and Technology, v. 40, p. 7207-7215.

Kinney, C.A., Fulong, E.T., Kolpin, D.W., Burkhardt, M.R., Zaugg, S.D., Werner, S.L., Bossio, J.P., and Benotti, M.J., 2008, Bioaccumulation of pharmaceuticals and other anthropogenic waste indicators in earthworms from agricultural soil amended with biosolid or swine manure: Environmental Science and Technology, v. 42, p. 1863-1870.

Kolpin, D.W., Furlong, E.T., Meyer, M.T., Thurman, E.M., Zaugg, S.D., Barber, L.B., and Buxton, H.T., 2002, Pharmaceuticals, hormones, and other organic wastewater contaminants in U.S. streams, 1999-2000-A national reconnaissance: Environmental Science and Technology, v. 36, p. $1202-1211$.

Kortenkamp, Andreas, 2007, Ten years of mixing cocktails: a review of combination effects of endocrine-disrupting chemicals: Environmental Health Perspectives, v.115, supplement 1, p. 98-105.

Lintelmann, J., Katayama, A., Kurihara, N., Shore, L., and Wenzel, A., 2003, Endocrine disruptors in the environment: Pure and Applied Chemistry, v. 75, no. 5, p. 631-681.
Loper, C.A., Crawford, J.K., Otto, K.L., Manning, R.L., Myer, M.T., and Furlong, E.T., 2007, Concentrations of selected pharmaceuticals and antibiotics in south-central Pennsylvania waters, March through September 2006: U.S. Geological Survey Data Series Report 300, 101 p.

Loraine, G.A., and Pettigrove, M.E., 2006, Seasonal variations in concentrations of pharmaceuticals and personal care products in drinking water and reclaimed wastewater in Southern California: Environmental Science and Technology, v. 40, no. 3, p. 687-695.

Low, D.J., and Conger, R.W., 2002, Ground-water availability in part of the Borough of Carroll Valley, Adams County, Pennsylvania, and the establishment of a drought-monitor well: U.S. Geological Survey Water-Resources Investigations Report 02-4273, 78 p.

Maine Department of Environmental Protection, 2010, Pharmaceutical drugs found in landfill water: Press release, January 14, 2010, accessed July 28, 2010, at $h t t p: / / w w w$. maine.gov/tools/whatsnew/index.php?topic $=D E P+N e w s \& i$ $d=88993 \& v=$ Article.

Mellon, Margaret, Benbrook, Charles, and Benbrook, K.L., 2001, Hogging it! Estimates of antimicrobial abuse in livestock: Union of Concerned Scientists, $110 \mathrm{p}$.

Meyer, M.T., Lee, E.A., Ferrell, G.M., Bumgarner, J.E., and Varns, J., 2007, Evaluation of offline tandem and online solid-phase extraction with liquid chromatography/electrospray ionization-mass spectrometry for analysis of antibiotics in ambient water and comparison to an independent method: U.S. Geological Survey Scientific Investigations Report 2007-5021, 28 p.

Monteiro, S.C., and Boxall, A.B.A., 2010, Occurrence and fate of human pharmaceuticals in the environment: Reviews of Environmental Contamination and Toxicology, v. 202, p. 53-154.

Oblinger, C.J., Gill, A.C., McPherson, A.K., Meyer, M.T., and Furlong, E.T., 2007, Occurrence of selected pharmaceuticals, personal-care products, organic wastewater compounds, and pesticides in the lower Tallapoosa River Watershed near Montgomery, Alabama, 2005: U.S. Geological Survey Scientific Investigations Report 2007-5266, $23 \mathrm{p}$.

Phillips, P.J., Smith, S.G., Kolpin, D.W., Zaugg, S.D., Buxton, H.T., Furlong, E.T., Esposito, K., and Stinson, B., 2010, Pharmaceutical formulation facilities as sources of opioids and other pharmaceuticals to wastewater treatment plant effluents: Environmental Science and Technology, v. 44, p. $4910-4916$.

Phillips, P., and Chalmers, A. 2009, Wastewater effluent, combined sewer overflows, and other sources of organic compounds to Lake Champlain: Journal of the American Water Resources Association (JAWRA), v. 45, no.1, p. 45-47. 
Rantz, S.E., and others, 1982, Measurement and computation of streamflow: Volume 1: Measurement of stage and discharge. Volume 2: Computation of discharge: U.S. Geological Survey Water-Supply Paper 2175, 631 p.

Ripley, J., Iwanowicz, L., Blazer, V., and Foran, C., 2008, Utilization of protein expression profiles as indicators of environmental impairment of smallmouth bass (Micropterus dolomieu) from the Shenandoah River, Virginia, USA: Environmental Toxicology and Chemistry, v. 27, no. 8, p. $1756-1767$.

Roberts, P.H., and Thomas, K.V., 2006, The occurrence of selected pharmaceutical compounds in wastewater effluent and surface waters of the lower Tyne catchment: Science of the Total Environment, v. 356, p. 143-153.

Robertson, L.S., Iwanowicz, L.R., and Marranca, J.M., 2009, Identification of centrarchid hepcidins and evidence that $17 \beta$-estradiol disrupts constitutive expression of hepcidin-1 and inductable expression of hepcidin-2 in largemouth bass (Micropterus salmoides): Fish and Shellfish Immunology, v. 26, p. 898-907.

Sarmah, A.K., Meyer, M.T., and Boxall, A.B.A., 2006, A global perspective on the use, sales, exposure pathways, occurrence, fate and effects of veterinary antibiotics (VAs) in the environment: Chemosphere, v. 65, p. 725-759.

Schwab, B.W., Hayes, E.P., Flori, J.M., Mastrocco, F.J., Roden, N.M., Craqin, D., Meyerhoff, R.D., D’Aco, V.J., and Anderson, P.D., 2005, Human pharmaceuticals in U.S. surface waters: a human health risk assessment: Regulatory Toxicology and Pharmacology, v. 42 (3), p. 296-312.

Sellin, M.K., Snow, D.D., Akerly, D.L., and Kolok, A.S., 2009, Estrogenic compounds downstream from three small cities in eastern Nebraska: occurrence and biological effect: Journal of the American Water Resources Association, v. 45, no. 1, p. 14-21.

Senior, L.A., and Cinotto, P.J., 2007, Effect of on-site wastewater disposal on quality of ground water and base flowA pilot study in Chester County, southeastern Pennsylvania, 2005: U.S. Geological Survey Open-File Report 2007$1253,50 \mathrm{p}$.

Senior, L.A., 2009, Groundwater-quality assessment, Pike County, Pennsylvania, 2007: U.S. Geological Scientific Investigations Report 2009-5129, 53 p.

Senior, L.A., and Sloto, R.A., 2010, Groundwater-quality monitoring program in Chester County, Pennsylvania, 1980-2008: U.S. Geological Scientific Investigations Report 2010-5087, 43 p.

Snyder, S.A., Wert, E.C., Lei, H., Westerhoff, P., and Yoon, Y., 2008, Removal of EDCs and pharmaceuticals in drinking and reuse treatment processes: Water Intelligence Online, v. 8 , January 2008
Snyder, S.A., Trenholm, R.A., Snyder, E.M., Bruce, G.M., Pleus, R.C., and Hemming, J.D.C., 2009, Toxicological relevance of EDCs and pharmaceuticals in drinking water: London, IWA Publishing, AWWA Research Foundation Report 91238, 146 p.

Stackelberg, P.E., Furlong, E.T., Meyer, M.T., Zaugg, S.D., Henderson, A.K., and Reissman, D.B., 2004, Persistence of pharmaceutical compounds and other organic wastewater contaminants in a conventional drinking-water treatment plant: Science of the Total Environment, v. 329, p. 99-113.

Stackelberg, P.E., Gibs, Jacob, Furlong, E.T., Meyer, M.T., Zaugg, S.D., and Lippincott, R.L., 2007, Efficiency of conventional drinking-water-treatment processes in removal of pharmaceuticals and other organic compounds: Science of the Total Environment, v. 377, p. 255-272.

Ternes, T.A., 1998, Occurrence of drugs in German sewage treatment plants and rivers: Water Research, v. 32, no. 11, p. 3245-3260.

Stuckey, M.H., 2006, Low-flow, base-flow, and mean-flow regression equations for Pennsylvania streams: U.S. Geological Survey Scientific Investigations Report 2006-5130, $84 \mathrm{p}$.

Tertuliani, J.S., Alvarez, D.A., Furlong, E.T., Meyer, M.T., Zaugg, S.D., Koltun, G.F., 2008, Occurrence of organic wastewater compounds in the Tinkers Creek Watershed and two other tributaries to the Cuyahoga River, Northeast Ohio: U.S. Geological Survey Scientific Investigations Report 2008-5173, 60 p.

Thorpe, K.L., Cummings, R.I., Hutchinson, T.H., Scholze, Martin, Brighty, Geoff, Sumpter, J.P., and Tyler, C.R., 2003, Relative potencies and combination effects of steroidal estrogens in fish: Environmental Science and Technology, v. 37 , no. 6 , p. 1142-1149.

Thorpe, K.L., Gross-Sorokin, Melanie, Johnson, Ian, Brighty, Geoff, and Tyler, C.R., 2006, An assessment of the model of concentration addition for predicting the estrogenic activity of chemical mixtures in wastewater treatment works effluent: Environmental Health Perspectives, v. 14, supplement 1, p. 90-97.

Tyler, C.R., and Jobling, Susan, 2008, Roach, sex, and genderbending chemicals: the feminization of wild fish in English rivers: BioScience, v. 58, no. 11, p. 1051-1059.

U.S. Food and Drug Administration, 2005, accessed January 25, 2012, at http://www.fda.gov/downloads/Drugs/ DrugSafety/DrugSafetyNewsletter/UCM148015.pdf

U.S. Geological Survey, 2006, Collection of water samples (ver. 2.0): U.S. Geological Survey Techniques of WaterResources Investigations, book 9, chap. A4, September 2006, accessed September 1, 2011, at http://pubs.water. usgs.gov/twri9A4/. 
U.S. Geological Survey, 2007-2010, Water-resources data for Pennsylvania water year 2006-2009: U.S. Geological Survey Water-Data Report WRD-US-2006-2009, accessed March 20, 2011, at http;//pa.water.usgs.gov/infodata/ surfacewater/annual_rpt.

Vajda, A.M., Barber, L.B., Gray, J.L., Lopez, E.M., Woodling, J.D., and Norris, D.O., 2008, Reproductive disruption in fish downstream from an estrogenic wastewater effluent: Environmental Science and Technology, v. 41, p. 3407-3414.

Webb, S., Ternes, T. Gilbert, M., and Olejniczak, K., 2003, Indirect human exposure to pharmaceuticals via drinking water: Toxicology Letters, v. 142, no. 3, p. 157-167.

Wilde, F.D., ed., 2004, Cleaning of equipment for water sampling (ver. 2.0): U.S. Geological Survey Techniques of Water-Resources Investigations, book 9, chap. A3, April 2004, accessed September 1, 2011, at http://pubs.water. usgs.gov/twri9A3/.

Wilde, F.D., Radtke, D.B., Gibs, Jacob, and Iwatsubo, R.T., eds., 2004 with updates through 2009, Processing of water samples (ver. 2.2): U.S. Geological Survey Techniques of Water-Resources Investigations, book 9, chap. A5, April 2004, accessed September 1, 2011, at http://pubs.water. usgs.gov/twri9A5/. (Separate updates for, 5.6.1.F, Wastewater, pharmaceutical, and antibiotic compounds, 5.6.4.A, are provided on the Web page.)

Wilde, F.D., ed., variously dated, Field measurements: U.S. Geological Survey Techniques of Water-Resources Investigations, book 9, chap. A6, accessed September 1, 2011, at http://pubs.water.usgs.gov/twri9A6/.

Wohl, Debra, and Bowne, D.R., 2008, Superbugs are everywhere! Antibiotic resistant bacteria in farms, forests, and front yards [abs]: Ecological Society of America, 93rd Annual Meeting, Milwaukee, Wisconsin, accessed September 1, 2011, at http://eco.confex.com/eco/2008/techprogram/ P11035.HTM.

Woodling, J.D., Lopez, E.M., Maldonado, T.A., Norris, D.O., and Vajda, A.M., 2006, Intersex and other reproductive disruption of fish in wastewater effluent dominated Colorado streams: Comparative Biochemistry and Physiology, Part C, v. 144 , p. $10-15$.

Zaugg, S.D., Smith, S.G., Schroeder, M.P., Barber, L.B., and Burkhardt, M.R., 2002, Methods of analysis by the U.S. Geological Survey National Water Quality Laboratorydetermination of wastewater compounds by polystyrenedivinylbenzene solid-phase extraction and capillary-column gas chromatography/mass spectrometry: U.S. Geological Survey Water Resources Investigations Report 01-4186, $37 \mathrm{p}$. 


\section{Tables 18 and 21}




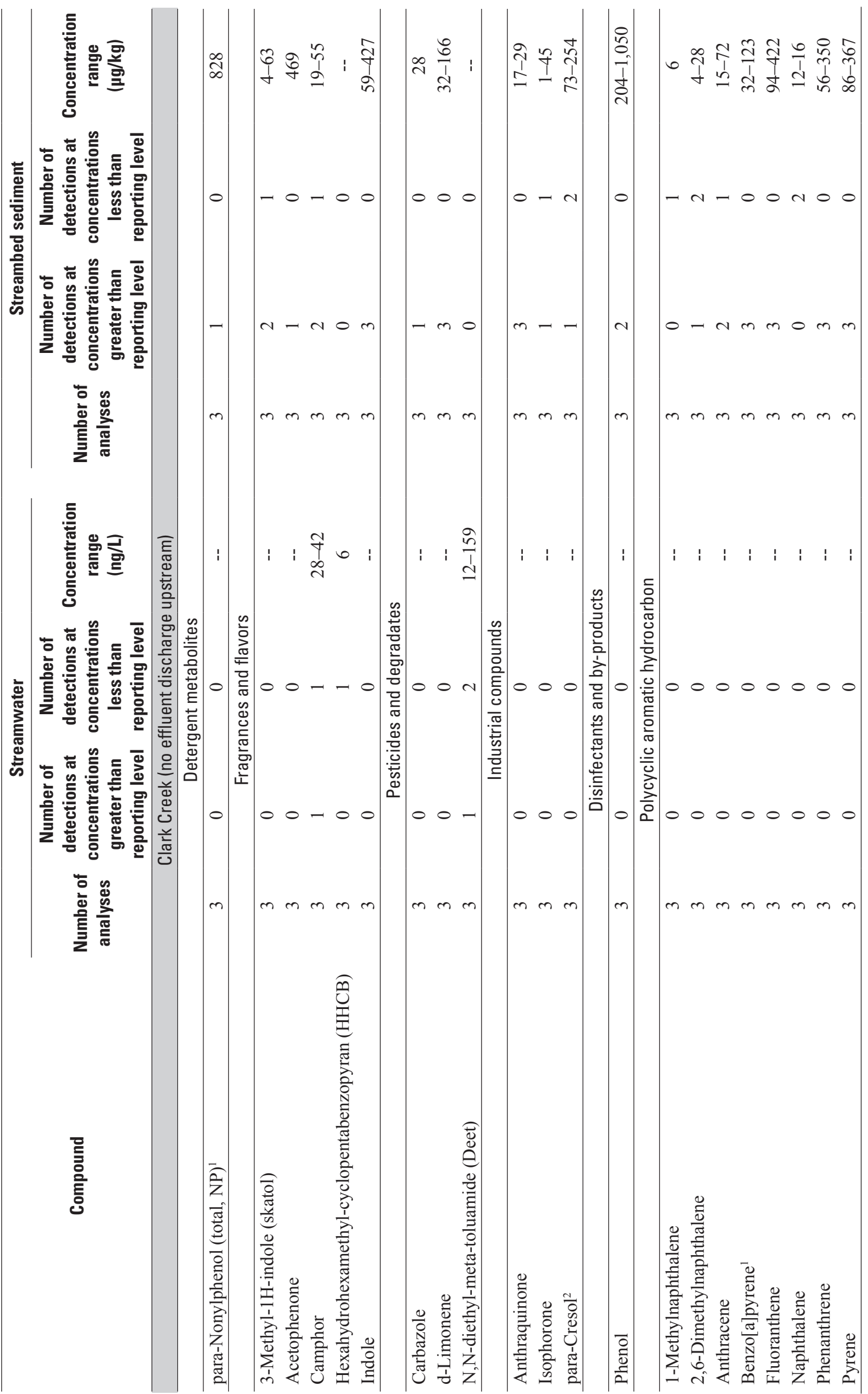




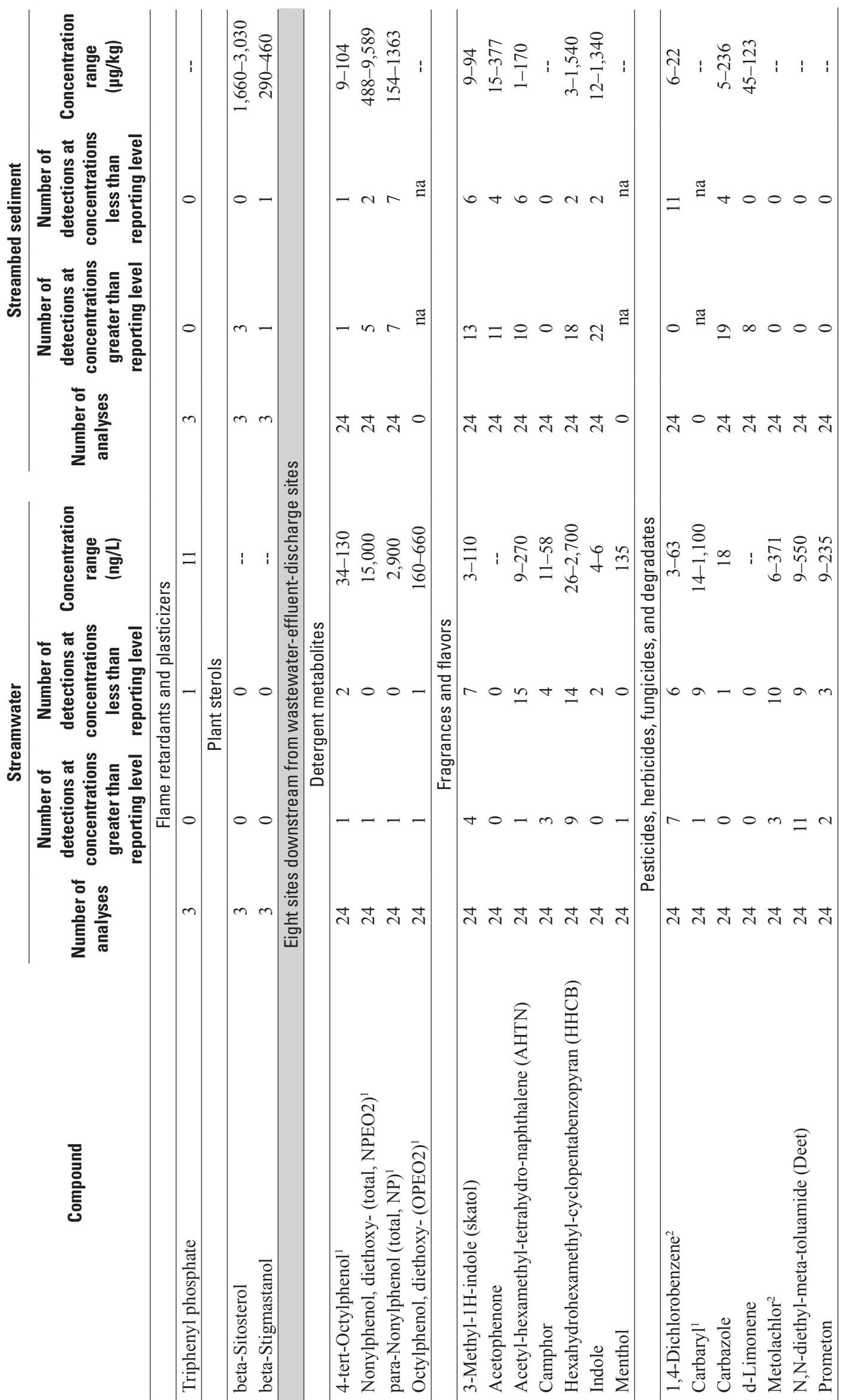




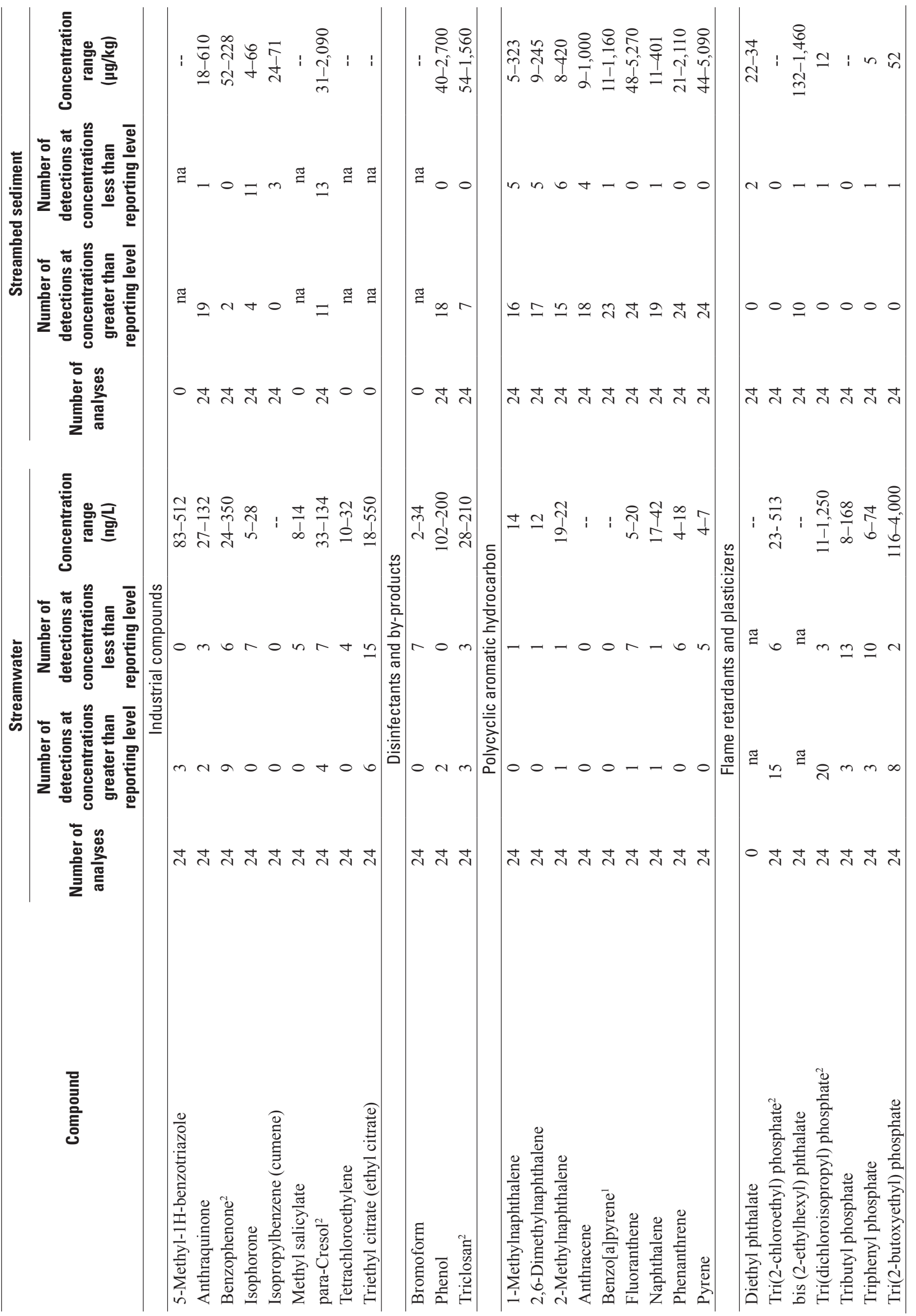




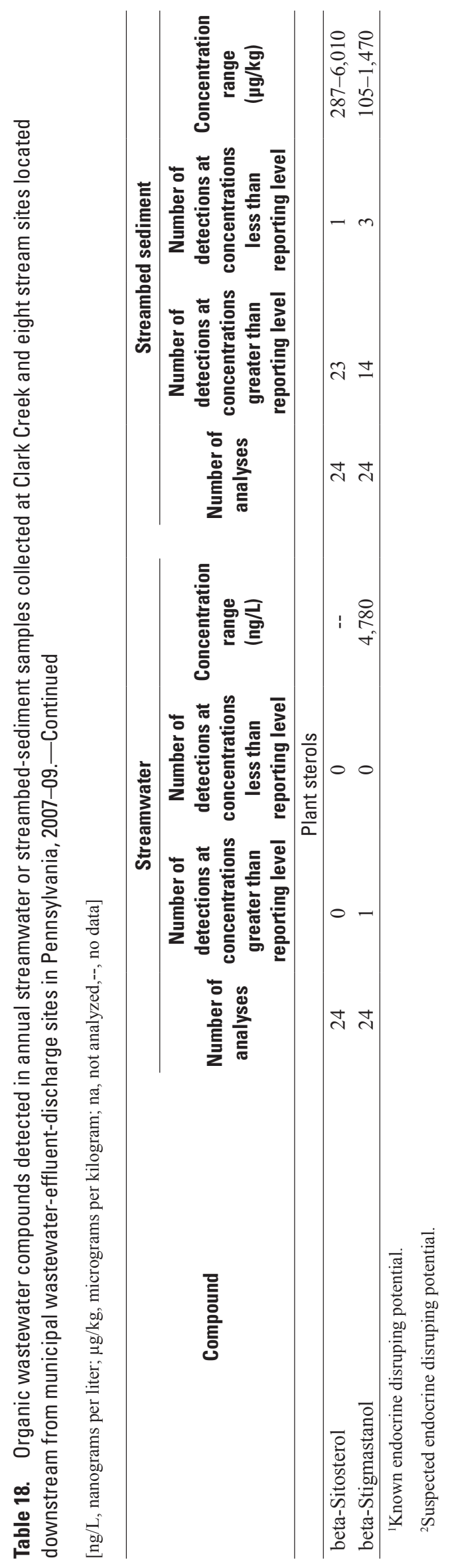




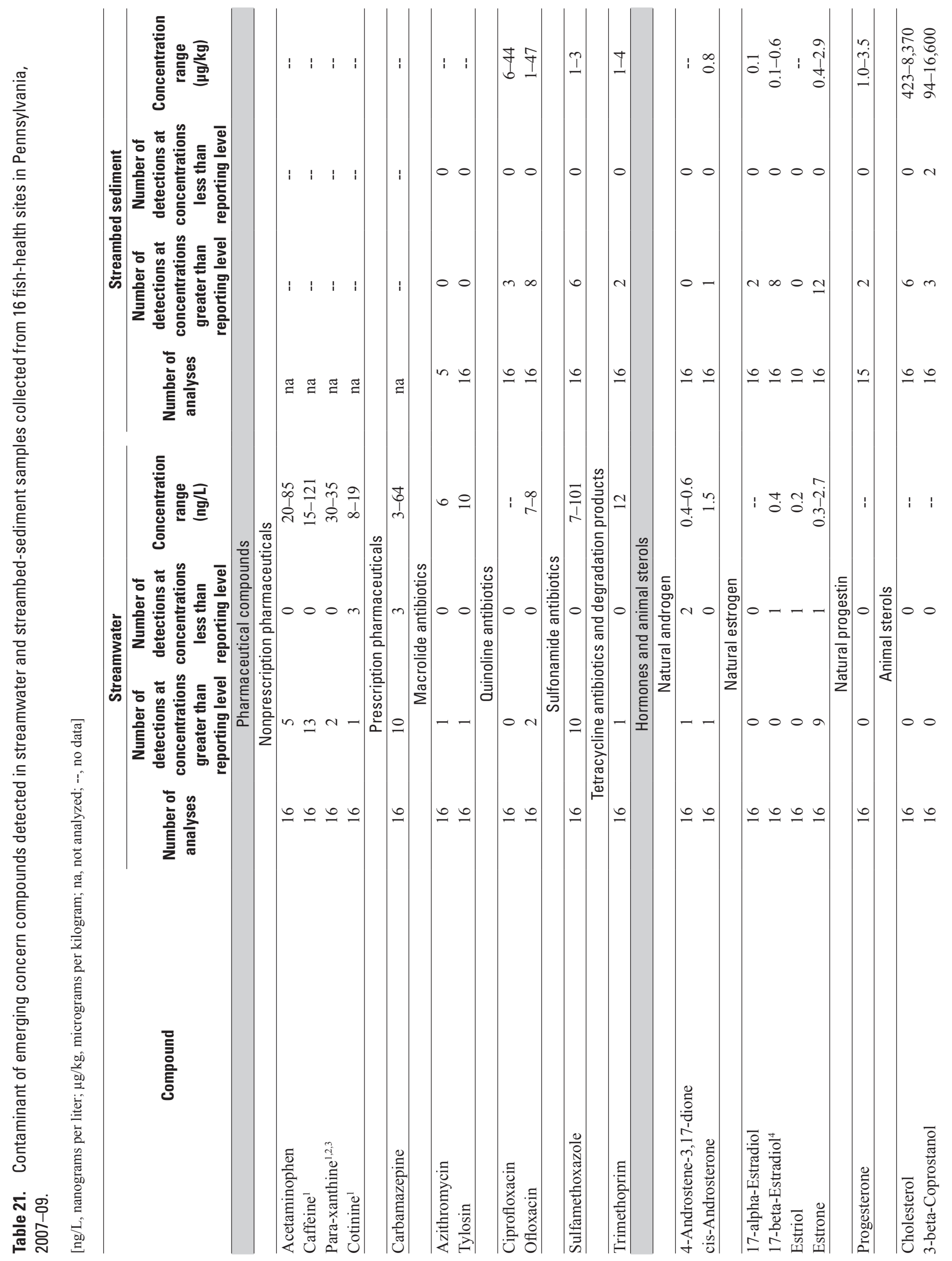




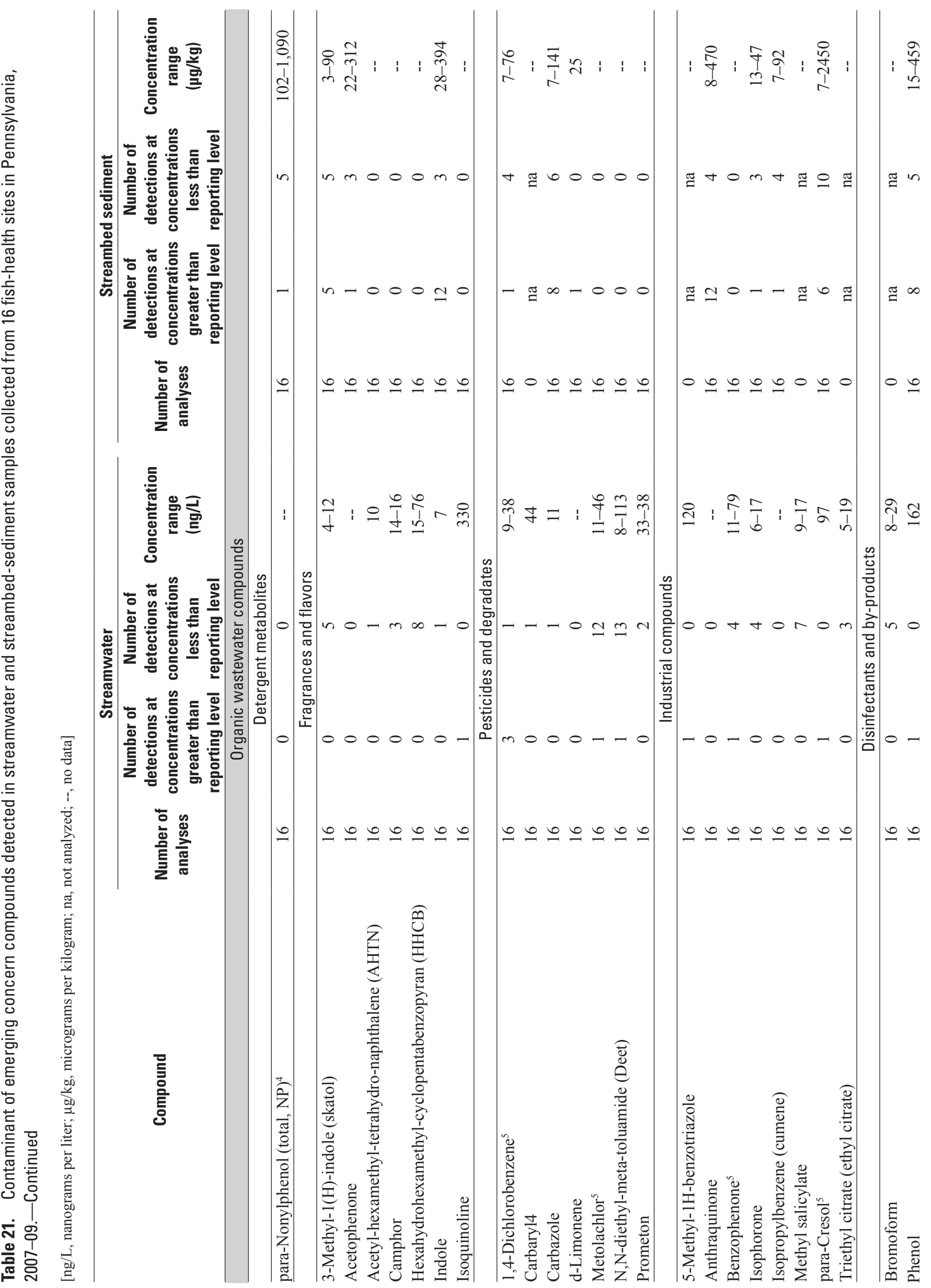

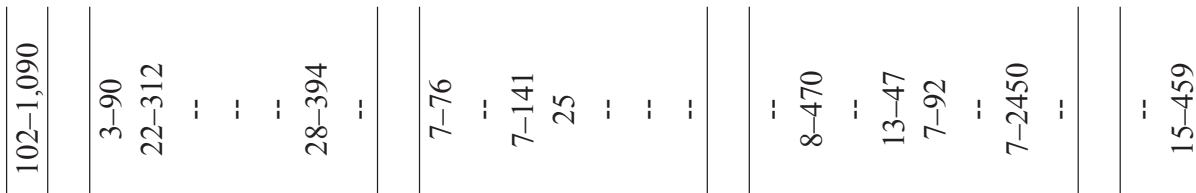
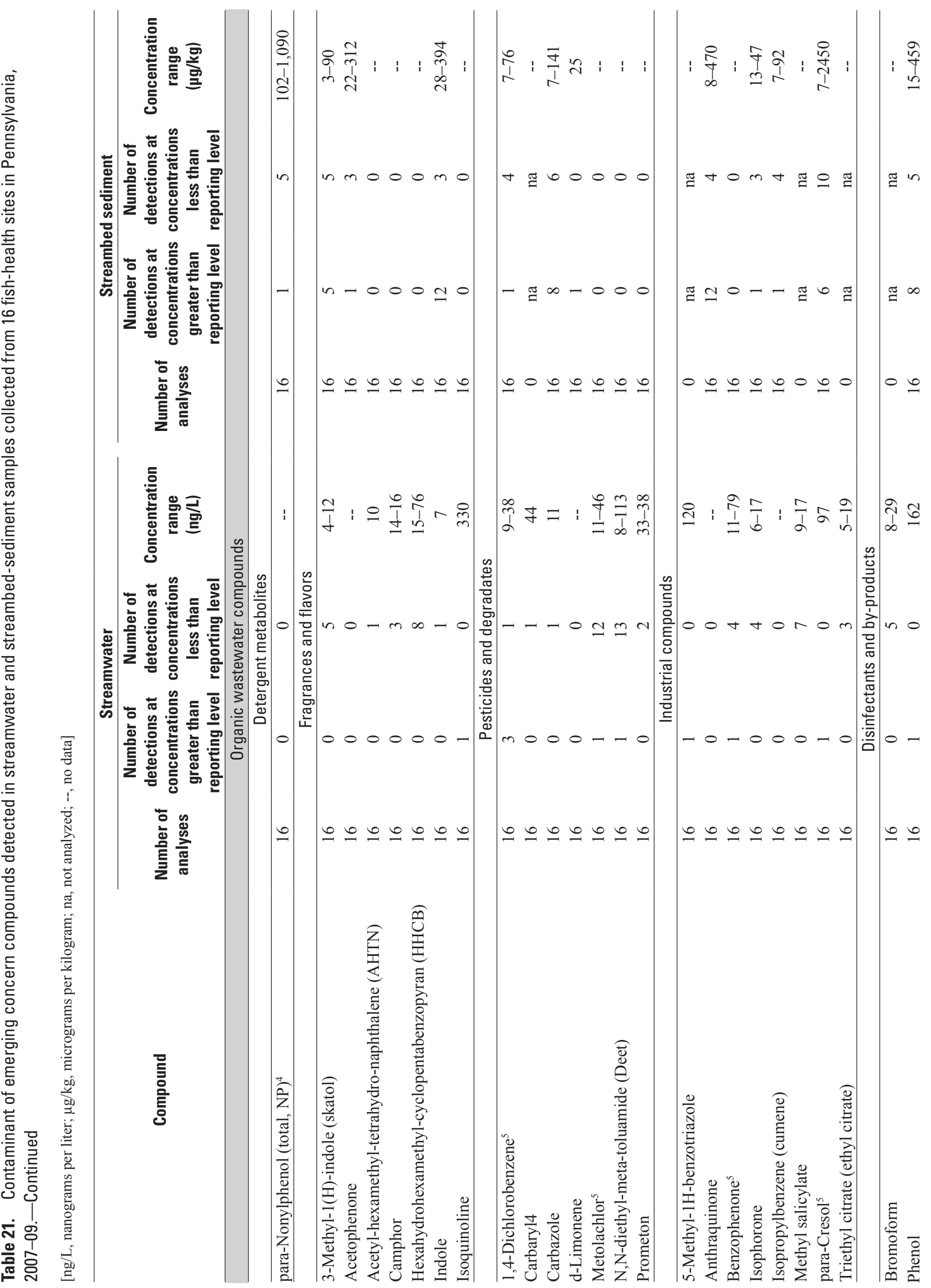


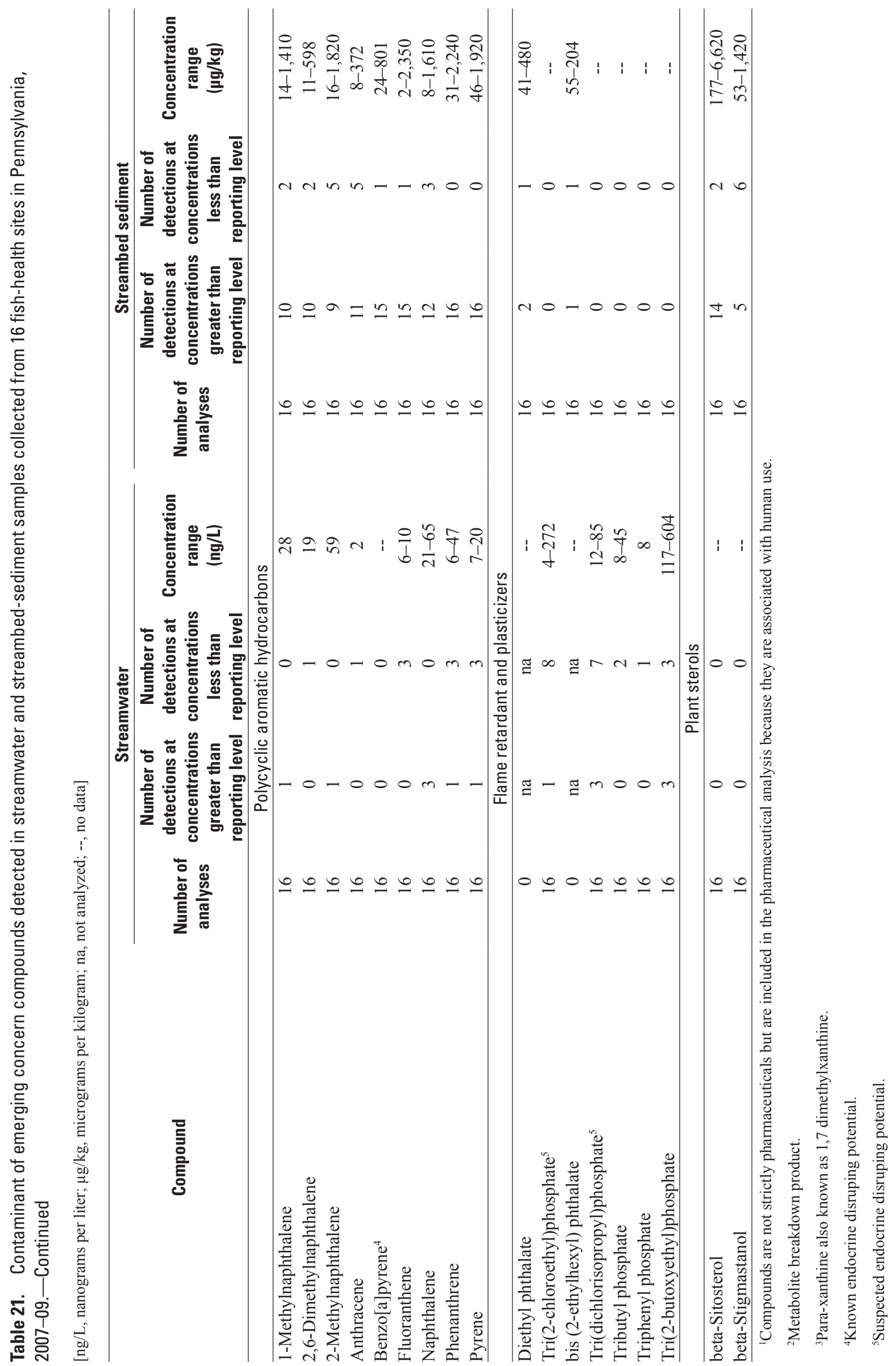


Appendixes A-C 


\section{Appendix A. Summary of laboratory methods}

\begin{tabular}{|c|c|c|c|c|}
\hline $\begin{array}{l}\text { Pharmaceutical } \\
\text { compounds in water }\end{array}$ & $\begin{array}{l}\text { Solid-phase extraction } \\
\text { with a modified } \\
\text { styrene-divinylbenzene } \\
\text { stationary phase }\end{array}$ & $\begin{array}{l}\text { High-performance liquid } \\
\text { chromatography using positive } \\
\text { electrospray ionization } \\
\text { operated in selective-ion } \\
\text { monitoring mode }\end{array}$ & USGS-NWQL & $\begin{array}{l}\text { Cahill and others, } 2004 \\
\text { Furlong and others, } 2008\end{array}$ \\
\hline Antibiotics in water & $\begin{array}{l}\text { On-line-solid phase extraction } \\
\text { using HLB Prospekt } \\
\text { cartridges }\end{array}$ & $\begin{array}{l}\text { Liquid chromatography followed } \\
\text { by multiple-reaction monitoring }\end{array}$ & USGS-OGRL & $\begin{array}{l}\text { Modified from Meyer } \\
\text { and others, } 2007\end{array}$ \\
\hline
\end{tabular}

\begin{tabular}{|c|c|c|c|c|}
\hline $\begin{array}{l}\text { Antibiotics in } \\
\text { streambed sediment }\end{array}$ & $\begin{array}{l}\text { Sonication followed by } \\
\text { accelerated solvent } \\
\text { extraction using methanol }\end{array}$ & $\begin{array}{l}\text { Liquid chromatography followed } \\
\text { by tandem mass spectrometry }\end{array}$ & USGS-OGRL & $\begin{array}{l}\text { M. Meyer, U.S. } \\
\text { Geological Survey, } \\
\text { written commun., } \\
\text { April } 2009\end{array}$ \\
\hline $\begin{array}{l}\text { Hormones and animal } \\
\text { sterols in water }\end{array}$ & $\begin{array}{l}\text { Multigrade glass-fiber filter } \\
\text { over a C18 solid-phase } \\
\text { extraction disk }\end{array}$ & $\begin{array}{l}\text { Elution with dichloromethane/ } \\
\text { methanol using solid-phase } \\
\text { extraction and analyzed using } \\
\text { gas chromatography/tandem } \\
\text { quadropole mass spectrometry }\end{array}$ & USGS-NWQL & $\begin{array}{l}\text { W. Foreman, U.S. } \\
\text { Geological Survey, } \\
\text { written commun., } \\
\text { October } 2008\end{array}$ \\
\hline
\end{tabular}

\begin{tabular}{|c|c|c|c|c|}
\hline $\begin{array}{l}\text { Hormones and } \\
\text { animal sterols in } \\
\text { streambed sediment }\end{array}$ & $\begin{array}{l}\text { Pure solvent extraction in } \\
\text { an accelerated solvent } \\
\text { extraction cell using } \\
\text { water:isopropyl alcohol } \\
\text { followed by solid- } \\
\text { phase extraction }\end{array}$ & $\begin{array}{l}\text { Elution with dichloromethane/ } \\
\text { methanol using solid-phase } \\
\text { extraction and analyzed using } \\
\text { gas chromatography/tandem } \\
\text { quadropole mass spectrometry }\end{array}$ & USGS-NWQL & $\begin{array}{l}\text { W. Foreman, U.S. } \\
\text { Geological Survey, } \\
\text { written commun., } \\
\text { October } 2008\end{array}$ \\
\hline $\begin{array}{l}\text { Organic wastewater } \\
\text { compounds in water }\end{array}$ & $\begin{array}{l}\text { Continuous liquid- } \\
\text { liquid extraction using } \\
\text { methylene chloride }\end{array}$ & $\begin{array}{l}\text { Capillary-column gas } \\
\text { chromatography/ } \\
\text { mass spectrometry }\end{array}$ & USGS-NWQL & Zaugg and others, 2002 \\
\hline
\end{tabular}

\begin{tabular}{|c|c|c|c|c|}
\hline $\begin{array}{l}\text { Organic wastewater } \\
\text { compounds in } \\
\text { streambed sediment }\end{array}$ & $\begin{array}{l}\text { High pressure water/isopropyl } \\
\text { alcohol extraction onto } \\
\text { solid-phase extraction } \\
\text { cartridges using polystyrene- } \\
\text { divinylbenzene resin }\end{array}$ & $\begin{array}{l}\text { Methylene chloride-diethyl } \\
\text { ether elution through a } \\
\text { Florisil/sodium sulfate } \\
\text { solid-phase extraction } \\
\text { cartridge and determination } \\
\text { by gas chromatography/ } \\
\text { mass spectrometry }\end{array}$ & USGS-NWQL & $\begin{array}{l}\text { Burkhart and others, } \\
2006\end{array}$ \\
\hline
\end{tabular}




\section{Appendix B. Summary of duplicate sample results}

Table B-1. Variability of pharmaceuticals (excluding antibiotics), hormones and animal sterols, and organic wastewater compounds using median relative percent differences for duplicate streamwater samples collected in Pennsylvania, 2006-09.

[Only compounds that had results greater than the reporting level in both samples were included. Analysis were conducted at the U.S. Geological Survey National Water Quality Laboratory in Denver, Colorado, unless otherwise indicated. RPD, relative percent difference]

\begin{tabular}{|c|c|c|c|}
\hline \multirow[b]{2}{*}{ Compound } & \multicolumn{3}{|c|}{$\begin{array}{l}\text { Variability, using median relative percent difference of concentrations } \\
\text { greater than the reporting level in duplicate sets }\end{array}$} \\
\hline & $\begin{array}{l}\text { Number of duplicate pairs } \\
\text { where both results } \\
\text { were greater than } \\
\text { the reporting level }\end{array}$ & Median RPD & $\begin{array}{l}\text { RPD or range } \\
\text { of RPDs }\end{array}$ \\
\hline \multicolumn{4}{|c|}{ Pharmaceuticals in water } \\
\hline \multicolumn{4}{|c|}{ Nonprescription pharmaceuticals } \\
\hline Acetaminophen & 2 & 10 & $3.4,17$ \\
\hline Caffeine & 5 & 9 & $1.3-25$ \\
\hline Ibuprofen $^{1}$ & 1 & 28 & 28 \\
\hline Para-xanthine & 1 & 16 & 16 \\
\hline Codeine & 2 & 11 & $8.6,13$ \\
\hline Cotinine & 2 & 17 & 12,22 \\
\hline Diphenhydramine & 2 & 30 & 22,39 \\
\hline \multicolumn{4}{|c|}{ Prescription pharmaceuticals } \\
\hline Carbamazepine & 4 & 3.2 & $2-21$ \\
\hline Diltiazem & 2 & 34 & 29,40 \\
\hline \multicolumn{4}{|c|}{ Hormones and animal sterols in water } \\
\hline 17-alpha-Ethynylestradiol & 1 & 11 & 11 \\
\hline 3-beta-Coprostanol & 1 & 2.8 & 2.8 \\
\hline 4-Androstene-3,17-dione & 1 & 6.7 & 6.7 \\
\hline Cholesterol & 1 & 1.3 & 1.3 \\
\hline Bisphenol A & 1 & 17 & 17 \\
\hline Estrone & 2 & 20 & 14,26 \\
\hline \multicolumn{4}{|c|}{ Organic wastewater compounds in water } \\
\hline Benzophenone & 1 & 3.1 & 3.1 \\
\hline DEET & 1 & 10 & 10 \\
\hline $\mathrm{HHCB}$ & 1 & 0 & 0 \\
\hline Triethyl citrate & 1 & 11 & 11 \\
\hline Tris(2- chloroethyl) phosphate & 2 & 0.26 & $0,0.53$ \\
\hline Tris(dichlorisopropyl) phosphate & 2 & 5.2 & $1.8,8.5$ \\
\hline 4-Nonylphenol, all isomers & 1 & 8 & 8 \\
\hline 4-Nonylphenol diethoxylate & 1 & 0 & 0 \\
\hline
\end{tabular}

\footnotetext{
${ }^{1}$ Analyzed at the U.S. Geological Survey Organic Research Geochemistry Laboratory in Lawrence, Kansas.
} 
Table B-2. Variability of antibiotics using median relative percent differences for duplicate streamwater samples collected in Pennsylvania, 2006-09.

[Analyses were conducted at the U.S. Geological Survey Organic Research Geochemistry Laboratory in Lawrence Kanas. RPD, relative percent difference]

Variability, using median relative percent difference of concentrations greater than the reporting level in duplicate sets

\begin{tabular}{|c|c|c|c|}
\hline Compound & $\begin{array}{l}\text { Number of duplicate pairs } \\
\text { where both results } \\
\text { were greater than } \\
\text { the reporting level }\end{array}$ & Median RPD & $\begin{array}{c}\text { RPD or range } \\
\text { of RPDs }\end{array}$ \\
\hline \multicolumn{4}{|c|}{ Antibiotics in water } \\
\hline \multicolumn{4}{|c|}{ Macrolide antibiotics } \\
\hline Azithromycin & 7 & 25 & $8.5-140$ \\
\hline Erythromycin & 4 & 8 & $0-12$ \\
\hline Erythromycin- $\mathrm{H}_{2} \mathrm{O}$ (anhydro-erythromycin) & 6 & 15 & $4.2-55$ \\
\hline Tylosin & 1 & 33 & 33 \\
\hline \multicolumn{4}{|c|}{ Quinoline antibiotics } \\
\hline Ciprofloxacin & 3 & 13 & $12-30$ \\
\hline Ofloxacin & 7 & 17 & $0-88$ \\
\hline \multicolumn{4}{|c|}{ Sulfonamide antibiotics } \\
\hline Sulfadiazine & 1 & 30 & 30 \\
\hline Sulfamethoxazole & 8 & 12 & $0.77-84$ \\
\hline \multicolumn{4}{|c|}{ Other antibiotics } \\
\hline Trimethoprim & 7 & 8.9 & $2.6-11$ \\
\hline
\end{tabular}


Table B-3. Variability of hormones and animal sterols, and organic wastewater compounds in streambed sediments using median relative percent differences for duplicate streambed-sediment samples collected in Pennsylvania, 2007-09.

[Analyses were conducted at the U.S. Geological Survey National Water Quality Laboratory in Denver, Colorado. RPD, relative percent difference]

\begin{tabular}{|c|c|c|c|}
\hline \multirow[b]{2}{*}{ Compound name } & \multicolumn{3}{|c|}{$\begin{array}{l}\text { Variability, using median relative percent difference of concentrations } \\
\text { greater than the reporting level in duplicate sets }\end{array}$} \\
\hline & $\begin{array}{l}\text { Number of duplicate pairs } \\
\text { where both results } \\
\text { were greater than } \\
\text { the reporting level }\end{array}$ & Median RPD & $\begin{array}{l}\text { RPD or range } \\
\text { of RPDs }\end{array}$ \\
\hline \multicolumn{4}{|c|}{ Hormones and animal streols in streambed sediment } \\
\hline cis-androsterone & 1 & 65 & 65 \\
\hline \multicolumn{4}{|c|}{ Natural estrogen } \\
\hline Equilenin & 1 & 34 & 34 \\
\hline Estrone & 3 & 33 & $5-45$ \\
\hline 17-beta-Estradiol & 1 & 73 & 73 \\
\hline Cholesterol & 4 & 54 & $5.9-159$ \\
\hline 3-beta-Coprostanol & 1 & 70 & 70 \\
\hline \multicolumn{4}{|c|}{ Organic wastewater compounds in streambed sediment } \\
\hline \multicolumn{4}{|c|}{ Detergent metabolites } \\
\hline Nonylphenol, diethoxy- (total, NPEO2) & 1 & 7 & 7 \\
\hline Octylphenol, monoethoxy-(OPEO1) & 1 & 10 & 10 \\
\hline Octylphenol, diethoxy- (OPEO2) & 1 & 8 & 8 \\
\hline para-Nonylphenol (total, NP) & 1 & 113 & 13 \\
\hline \multicolumn{4}{|c|}{ Fragrances and flavors } \\
\hline 3-Methyl-1H-indole (skatol) & 1 & 32 & 32 \\
\hline Benzophenone & 1 & 14 & 14 \\
\hline Para-cresol (p-cresol) & 2 & 72 & 7,136 \\
\hline \multicolumn{4}{|c|}{ Disinfectants and by-products } \\
\hline Phenol & 1 & 52 & 52 \\
\hline Triclosan & 1 & 12 & 12 \\
\hline \multicolumn{4}{|c|}{ Polycyclic aromatic hydrocarbons } \\
\hline 1-Methylnapthalene & 1 & 38 & 38 \\
\hline 2,6-Dimethylnaphthalene & 2 & 11 & $5.9,16$ \\
\hline 2-Methylnaphthalene & 2 & 20 & $4.4,36$ \\
\hline Anthracene & 1 & 0 & 0 \\
\hline Benzo[a]pyrene & 2 & 45 & 74,16 \\
\hline Fluoranthene & 4 & 57 & $3.6-108$ \\
\hline Naphthalene & 2 & 21 & $5.3,36$ \\
\hline Phenanthrene & 4 & 64 & $4.7-138$ \\
\hline Pyrene & 4 & 53 & 2.3-99 \\
\hline \multicolumn{4}{|c|}{ Plant sterol } \\
\hline Beta-Sitosterol & 4 & 54 & $2-85$ \\
\hline
\end{tabular}


Table B-4. Variability of antibiotics using median relative percent differences for duplicate streambed-sediment samples collected in Pennsylvania, 2007-09.

[Analyses were conducted at the U.S. Geological Survey Organic Research Geochemistry Laboratory in Lawrence, Kansas. RPD, relative percent difference]

\begin{tabular}{|c|c|c|c|}
\hline \multirow[b]{2}{*}{ Compound name } & \multicolumn{3}{|c|}{$\begin{array}{l}\text { Variability, using median relative percent difference of concentrations } \\
\text { greater than the reporting level in duplicate sets }\end{array}$} \\
\hline & $\begin{array}{l}\text { Number of duplicate pairs } \\
\text { where both results } \\
\text { were greater than } \\
\text { the reporting level }\end{array}$ & Median RPD & $\begin{array}{c}\text { RPD or range } \\
\text { of RPDs }\end{array}$ \\
\hline \multicolumn{4}{|c|}{ Antibiotics in streambed sediments } \\
\hline \multicolumn{4}{|c|}{ Quinoline antibiotics } \\
\hline Ciprofloxacin & 2 & 44 & 28,60 \\
\hline Ofloxacin & 3 & 7.2 & $6.7-17$ \\
\hline \multicolumn{4}{|c|}{ Sulfonamide antibiotic } \\
\hline Sulfamethoxazole & 2 & 20 & 0,40 \\
\hline \multicolumn{4}{|c|}{ Other antibiotic } \\
\hline Trimethoprim & 4 & 20 & $4.5-44$ \\
\hline \multicolumn{4}{|c|}{ Macrolide antibiotic } \\
\hline Azithromycin & 1 & 69 & 69 \\
\hline \multicolumn{4}{|c|}{ Tetracycline antibiotic } \\
\hline Tetracycline & 1 & 0 & 0 \\
\hline
\end{tabular}




\section{Appendix C. Reagent-spiked and laboratory-spiked sampled results}

Table C-1. Hormone compound recoveries in a reagent-spiked laboratory sample, November 11, 2007.

[Analyses were conducted at the U.S. Geological Survey National Water Quality Laboratory (NWQL) in Denver, Colorado; ng/L, nanograms per liter]

\begin{tabular}{lccc}
\hline \multicolumn{1}{c}{ Compound } & $\begin{array}{c}\text { Spike } \\
\text { concentration } \\
\text { (ng/L) }\end{array}$ & $\begin{array}{c}\text { Spiked reagent } \\
\text { sample concentration } \\
\text { (ng/L) }\end{array}$ & $\begin{array}{c}\text { Percent } \\
\text { recovery }\end{array}$ \\
\hline 4-Androstene-3,17-dione & 4.24 & 4.49 & 106.0 \\
cis-Androsterone & 1.56 & 1.65 & 106.0 \\
11-Ketotestosterone & 1.34 & 1.11 & 83.1 \\
\hline Equilenin & Natural estrogen & 47.0 \\
Equilin & 4.08 & 1.94 & 73 \\
17-alpha-Estradiol & 6.80 & 4.98 & 69 \\
17-beta-Estradiol & 2.01 & 1.38 & 81 \\
Estrone & 2.79 & 2.26 & 114 \\
\hline & 4.20 & 4.79 & 65.80 \\
\hline 17-alpha-Ethynylestradiol & 2.12 & 108 \\
Mestranol & 1.61 & 1.74 & 77.8 \\
\hline
\end{tabular}


Table C-2. Antibiotic and pharmaceutical compound recoveries in the laboratory-spiked environmental streamwater sample collected from Snitz Creek (A7, 01574050), Pennsylvania, on March 16, 2006.

[Only compounds that were detected in associated un-spiked environmental samples are included. Analyses were conducted at the U.S. Geological Survey Organic Geochemistry Research Laboratory in Lawrence, Kansas. Less-than values were set equal to zero for calculations. <, less than; ng/L, nanograms per liter]

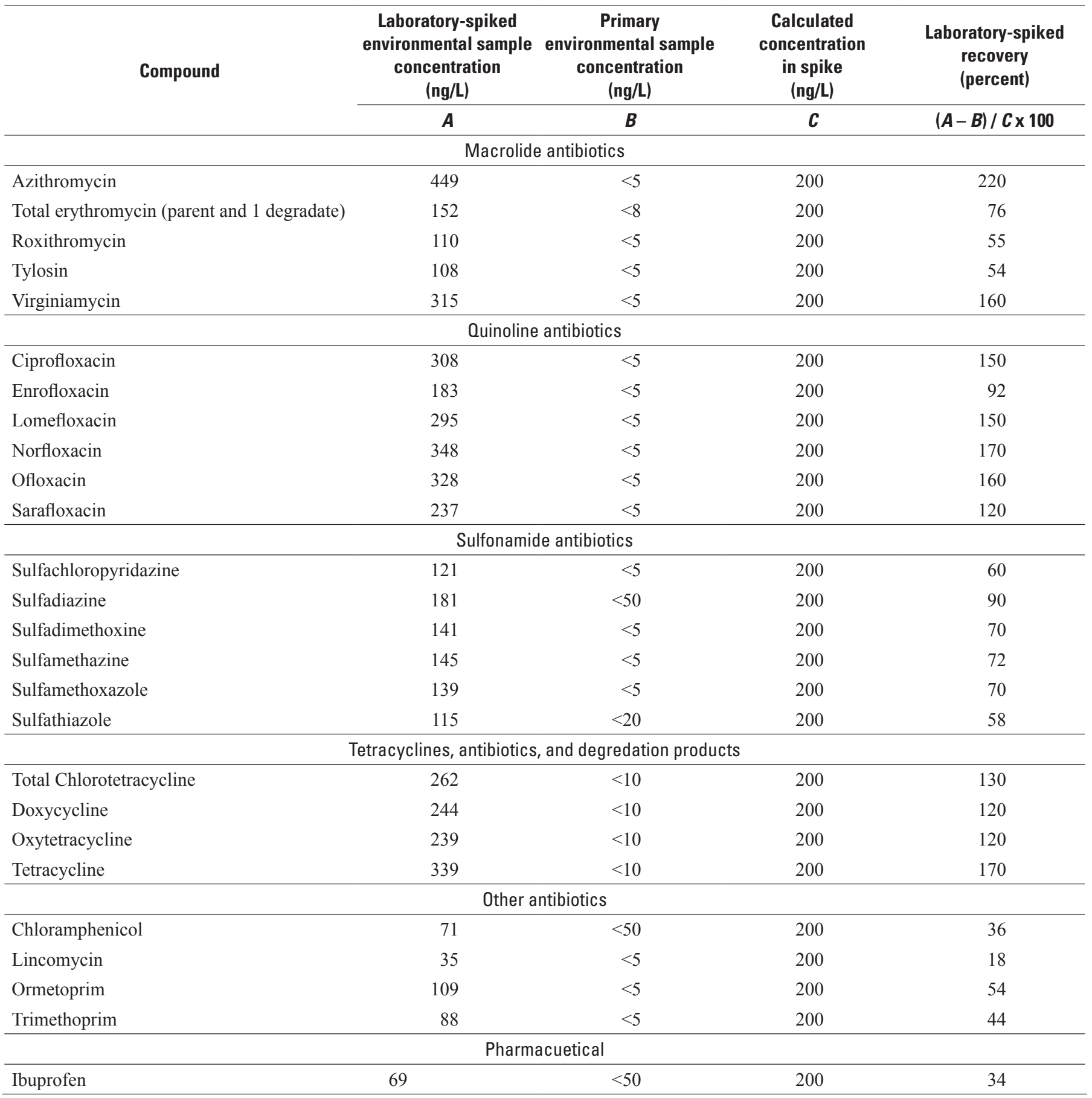


Table C-3. Antibiotic and pharmaceutical compound recoveries in the laboratory-spiked environmental streamwater sample collected from Snitz Creek (A8, 01574055), Pennsylvania, on May 1, 2006.

[Only compounds that were detected in associated un-spiked environmental samples are included. Analyses were conducted at the U.S. Geological Survey Organic Geochemistry Research Laboratory in Lawrence, Kansas. Less-than values were set equal to zero for calculations. <, less than; shading indicates detection in primary environmental sample; ng/L, nanograms per liter]

\begin{tabular}{|c|c|c|c|c|}
\hline \multirow[t]{2}{*}{ Compound } & $\begin{array}{l}\text { Laboratory-spiked } \\
\text { environmental sample } \\
\text { concentration } \\
\text { (ng/L) }\end{array}$ & $\begin{array}{c}\text { Primary } \\
\text { environmental sample } \\
\text { concentration } \\
\text { (ng/L) }\end{array}$ & $\begin{array}{l}\text { Calculated } \\
\text { concentration } \\
\text { in spike } \\
\text { (ng/L) }\end{array}$ & $\begin{array}{l}\text { Laboratory-spiked } \\
\text { recovery } \\
\text { (percent) }\end{array}$ \\
\hline & $\boldsymbol{A}$ & $B$ & $C$ & $(A-B) / C \times 100$ \\
\hline \multicolumn{5}{|c|}{ Macrolide antibiotics } \\
\hline Azithromycin & 106 & $<5$ & 200 & 53 \\
\hline Erythromycin (total) & 140 & $<8$ & 200 & 70 \\
\hline Roxithromycin & 170 & $<5$ & 200 & 85 \\
\hline Tylosin & 365 & 27 & 200 & 170 \\
\hline Virginiamycin & 150 & $<5$ & 200 & 75 \\
\hline \multicolumn{5}{|c|}{ Quinoline antibiotics } \\
\hline Ciprofloxacin & 219 & $<5$ & 200 & 110 \\
\hline Enrofloxacin & 288 & $<5$ & 200 & 140 \\
\hline Lomefloxacin & 166 & $<5$ & 200 & 83 \\
\hline Norfloxacin & 151 & $<5$ & 200 & 76 \\
\hline Ofloxacin & 186 & $<5$ & 200 & 93 \\
\hline Sarafloxacin & 189 & $<5$ & 200 & 94 \\
\hline \multicolumn{5}{|c|}{ Sulfonamide antibiotics } \\
\hline Sulfachloropyridazine & 269 & $<5$ & 200 & 130 \\
\hline Sulfadiazine & 266 & $<50$ & 200 & 130 \\
\hline Sulfadimethoxine & 244 & $<5$ & 200 & 120 \\
\hline Sulfamethazine & 334 & $<5$ & 200 & 170 \\
\hline Sulfamethoxazole & 229 & $<5$ & 200 & 110 \\
\hline Sulfathiazole & 277 & $<20$ & 200 & 140 \\
\hline \multicolumn{5}{|c|}{ Tetracycline antibiotics and degradation products } \\
\hline Chlorotetracycline (total) & 254 & $<10$ & 200 & 130 \\
\hline Doxycycline & 292 & $<10$ & 200 & 150 \\
\hline Oxytetracycline & 202 & $<10$ & 200 & 100 \\
\hline Tetracycline & 236 & $<10$ & 200 & 120 \\
\hline \multicolumn{5}{|c|}{ Other antibiotics } \\
\hline Chloramphenicol & 155 & $<50$ & 200 & 78 \\
\hline Lincomycin & 107 & $<5$ & 200 & 54 \\
\hline Ormetoprim & 334 & $<5$ & 200 & 170 \\
\hline Trimethoprim & 338 & $<5$ & 200 & 170 \\
\hline \multicolumn{5}{|c|}{ Pharmaceutical } \\
\hline Ibuprofen & 202 & $<50$ & 200 & 100 \\
\hline
\end{tabular}


Table C-4. Antibiotic and pharmaceutical compound recoveries in the laboratory-spiked environmental streamwater sample collected from Quittapahilla Creek (T9, 01573160), Pennsylvania, on July 12, 2007.

[Only compounds that were detected in associated un-spiked environmental samples are included. Analyses were conducted at the U.S. Geological Survey Organic Geochemistry Research Laboratory in Lawrence, Kansas. Less-than values were set equal to zero for calculations. <, less than; shading indicates detection in primary environmental sample; ng/L, nanograms per liter]

\begin{tabular}{|c|c|c|c|c|}
\hline \multirow[t]{2}{*}{ Compound } & $\begin{array}{c}\text { Laboratory-spiked } \\
\text { environmental sample } \\
\text { concentration } \\
\text { (ng/L) }\end{array}$ & $\begin{array}{c}\text { Primary } \\
\text { environmental sample } \\
\text { concentration } \\
\text { (ng/L) }\end{array}$ & $\begin{array}{l}\text { Calculated } \\
\text { concentration } \\
\text { in spike } \\
\text { (ng/L) }\end{array}$ & $\begin{array}{l}\text { Laboratory-spiked } \\
\text { recover } \\
\text { (percent) }\end{array}$ \\
\hline & $A$ & $B$ & $C$ & $(A-B) / C \times 100$ \\
\hline \multicolumn{5}{|c|}{ Macrolide antibiotics } \\
\hline Azithromycin & 167 & $<5$ & 200 & 84 \\
\hline Erythromycin (total) & 262 & 31 & 200 & 116 \\
\hline Roxithromycin & 164 & $<5$ & 200 & 82 \\
\hline Tylosin & 237 & $<5$ & 200 & 118 \\
\hline Virginiamycin & 139 & $<5$ & 200 & 70 \\
\hline \multicolumn{5}{|c|}{ Quinoline antibiotics } \\
\hline Ciprofloxacin & 137 & $<5$ & 200 & 68 \\
\hline Enrofloxacin & 140 & $<5$ & 200 & 70 \\
\hline Lomefloxacin & 190 & $<5$ & 200 & 95 \\
\hline Norfloxacin & 155 & $<5$ & 200 & 78 \\
\hline Ofloxacin & 176 & 6 & 200 & 85 \\
\hline Sarafloxacin & 192 & $<5$ & 200 & 96 \\
\hline \multicolumn{5}{|c|}{ Sulfonamide antibiotics } \\
\hline Sulfachloropyridazine & 193 & $<5$ & 200 & 96 \\
\hline Sulfadiazine & 224 & $<100$ & 200 & 112 \\
\hline Sulfadimethoxine & 218 & $<5$ & 200 & 109 \\
\hline Sulfamethazine & 186 & $<5$ & 200 & 93 \\
\hline Sulfamethoxazole & 214 & 13 & 200 & 100 \\
\hline Sulfathiazole & 208 & $<20$ & 200 & 104 \\
\hline \multicolumn{5}{|c|}{ Tetracycline antibiotics and degradation products } \\
\hline Chlorotetracycline (total) & 474 & $<10$ & 200 & 237 \\
\hline Doxycycline & 200 & $<10$ & 200 & 100 \\
\hline Oxytetracycline & 162 & $<10$ & 200 & 81 \\
\hline Tetracycline & 178 & $<10$ & 200 & 89 \\
\hline \multicolumn{5}{|c|}{ Other antibiotics } \\
\hline Chloramphenicol & 138 & $<100$ & 200 & 69 \\
\hline Lincomycin & 154 & $<5$ & 200 & 77 \\
\hline Ormetoprim & 196 & $<5$ & 200 & 98 \\
\hline Trimethoprim & 223 & 25 & 200 & 99 \\
\hline \multicolumn{5}{|c|}{ Pharmaceutical } \\
\hline Ibuprofen & 79 & $<50$ & 200 & 40 \\
\hline
\end{tabular}


Table C-5. Pharmaceutical compound recoveries in a laboratory-spiked environmental streamwater sample collected from Middle Spring Creek (T4, 01563158), Pennsylvania May 10, 2006.

[Only compounds that were detected in associated un-spiked environmental samples are included. Analyses were conducted at the U.S. Geological Survey National Water Quality Laboratory (NWQL) in Denver, Colorado. Less-than values were set equal to zero for calculations. e, estimated value; <, less than; shading indicates detection in primary environmental sample; LRS, laboratory-reagent spike; ng/L, nanograms per liter]

\begin{tabular}{|c|c|c|c|c|c|}
\hline Compound & $\begin{array}{c}\text { Laboratory-spiked } \\
\text { environmental sample } \\
\text { concentration } \\
\text { (ng/L) }\end{array}$ & $\begin{array}{c}\text { Primary } \\
\text { environmental sample } \\
\text { concentration } \\
\text { (ng/L) }\end{array}$ & $\begin{array}{l}\text { Calculated } \\
\text { concentration } \\
\text { in spike } \\
\text { (ng/L) }\end{array}$ & $\begin{array}{l}\text { Laboratory-spiked } \\
\text { recovery } \\
\text { (percent) }\end{array}$ & $\begin{array}{l}\text { LRS, NWQL } \\
\text { quality-control } \\
\text { preparation set } \\
\text { recovery } \\
\text { (percent) }\end{array}$ \\
\hline \multicolumn{6}{|c|}{ Nonprescription pharmaceuticals } \\
\hline Acetaminophen & 269 & e 8 & 257 & 102 & 71 \\
\hline Para-xanthine ${ }^{1,2}$ & 243 & $<21$ & 257 & 95 & 80 \\
\hline Codeine & 293 & 29 & 257 & 103 & 87 \\
\hline Cotinine $^{1}$ & 251 & e 4 & 257 & 96 & 101 \\
\hline Diphenhydramine & 196 & 71 & 257 & 49 & 64 \\
\hline Diltiazem & e 148 & e 32 & 257 & 45 & e 15 \\
\hline Salbutamol (albuterol) & 264 & e 5 & 257 & 101 & 77 \\
\hline Thiabendazole & 97 & $<25$ & 257 & 38 & 86 \\
\hline Warfarin & 229 & $<19$ & 257 & 89 & 31 \\
\hline
\end{tabular}

${ }^{1}$ Compounds are not strictly pharmaceuticals but are included in the pharmaceutical analysis because they are associated with human use.

${ }^{2}$ Degradation product of caffeine. Also known as p-xanthine and 1,7 dimethylxanthine. 
Table C-6. Pharmaceutical compound recoveries in a laboratory-spiked environmental streamwater sample collected from Quittaphilla Creek Creek (T9, 01573160), Pennsylvania, July 12, 2007.

[Only compounds that were detected in associated un-spiked environmental samples are included. Analyses were conducted at the U.S. Geological Survey National Water Quality Laboratory (NWQL) in Denver, Colorado. Less-than values were set equal to zero for calculations; e, estimated value; <, less than; shading indicates detection in primary environmental sample; LRS, laboratory-reagent spike; ng/L, nanograms per liter]

\begin{tabular}{|c|c|c|c|c|c|}
\hline \multirow[t]{2}{*}{ Compound } & $\begin{array}{l}\text { Laboratory-spiked } \\
\text { environmental } \\
\text { sample } \\
\text { concentration } \\
\text { (ng/L) }\end{array}$ & $\begin{array}{c}\text { Primary } \\
\text { environmental } \\
\text { sample } \\
\text { concentration } \\
\text { (ng/L) }\end{array}$ & $\begin{array}{l}\text { Calculated } \\
\text { concentration } \\
\text { in spike } \\
\text { (ng/L) }\end{array}$ & $\begin{array}{l}\text { Laboratory-spiked } \\
\text { recovery } \\
\text { (percent) }\end{array}$ & \multirow[t]{2}{*}{$\begin{array}{l}\text { LRS, NWOL } \\
\text { quality-control } \\
\text { preparation set } \\
\text { recovery } \\
\text { (percent) }\end{array}$} \\
\hline & $A$ & $\boldsymbol{B}$ & $\boldsymbol{C}$ & $(A-B) / C \times 100$ & \\
\hline \multicolumn{6}{|c|}{ Non-prescription pharmaceuticals } \\
\hline Caffeine $^{1}$ & e 222 & $<15$ & 269 & 82 & 131 \\
\hline Para-xanthine $e^{1,2}$ & e 162 & $<21$ & 269 & 60 & e 163 \\
\hline Codeine & 219 & $<22$ & 269 & 81 & 84 \\
\hline Cotinine $^{1}$ & 199 & $<28$ & 269 & 74 & 92 \\
\hline Diphenhydramine & 188 & $<23$ & 269 & 70 & 59 \\
\hline Diltiazem & e 170 & $<18$ & 269 & 63 & e 23 \\
\hline Salbutamol (albuterol) & 246 & $<14$ & 269 & 92 & 111 \\
\hline Thiabendazole & 147 & $<25$ & 269 & 55 & 96 \\
\hline Warfarin & 288 & $<19$ & 269 & 107 & 51 \\
\hline
\end{tabular}

${ }^{1}$ Compounds are not strictly pharmaceuticals but are included in the pharmaceutical analysis because they are associated with human use.

${ }^{2}$ Degradation product of caffeine. Also known as p-xanthine and 1,7 dimethylxanthine. 
Table C-7. Hormone and animal sterol compound recoveries in a laboratory-spiked environmental streamwater sample collected from Quittaphilla Creek Creek (T9, 01573160), Pennsylvania, July 12, 2007.

[Only compounds that were detected in associated un-spiked environmental samples are included. Analyses were conducted at the U.S. Geological Survey National Water Quality Laboratory (NWQL) in Denver, Colorado. Less-than values were set equal to zero for calculations; e, estimated value; <, less than; shading indicates detection in primary environmental sample; LRS, laboratory-reagent spike; ng/L, nanograms per liter]

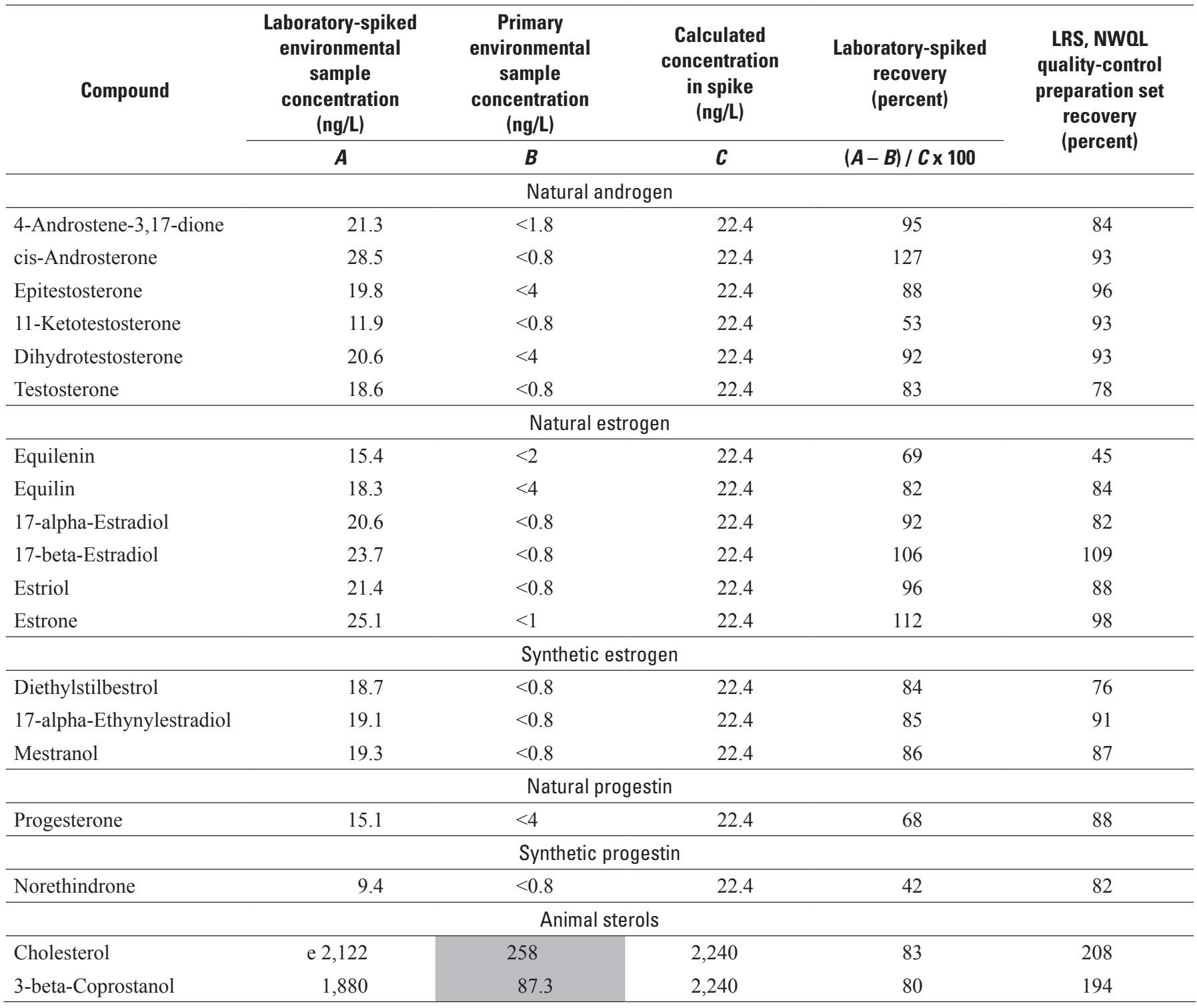




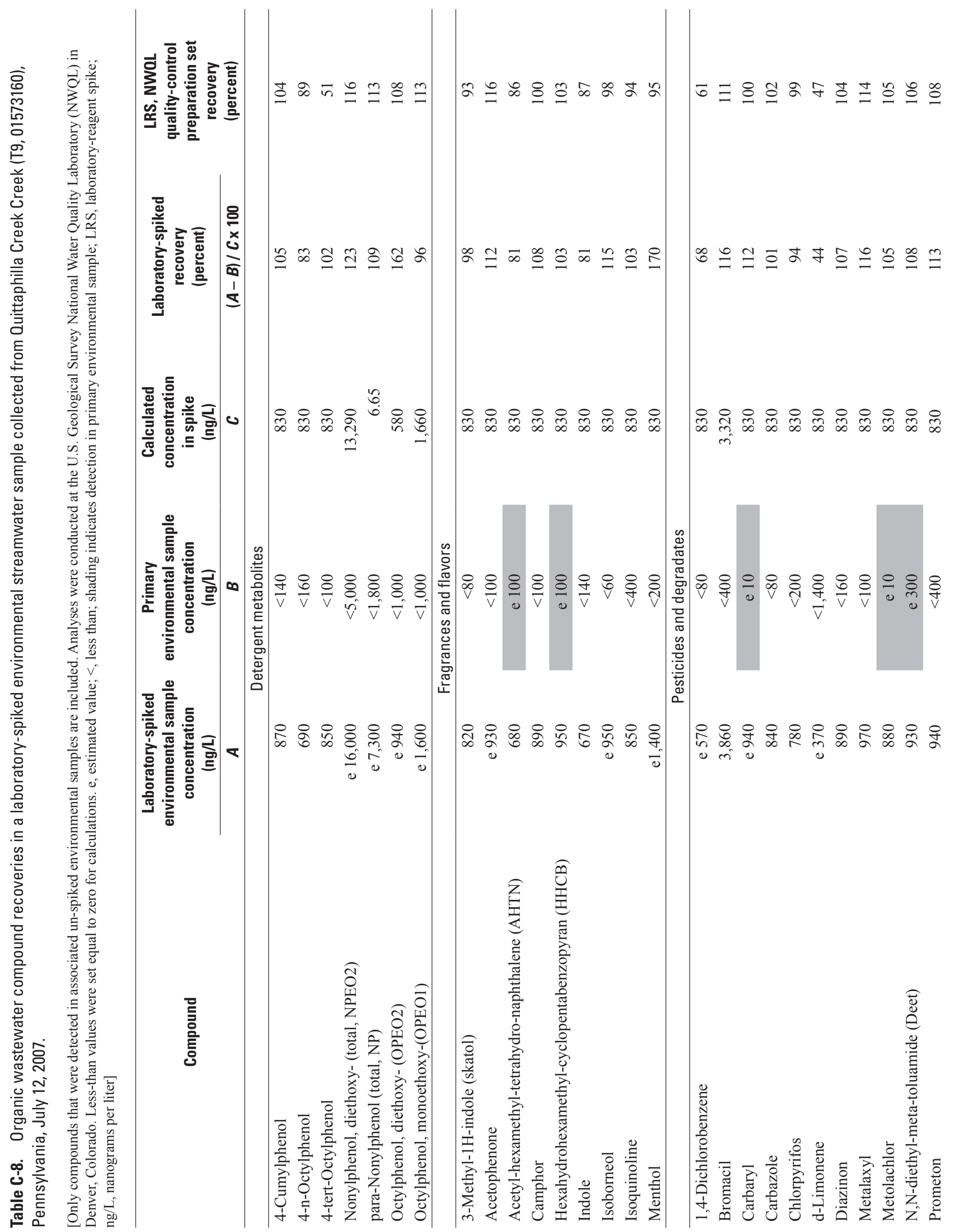




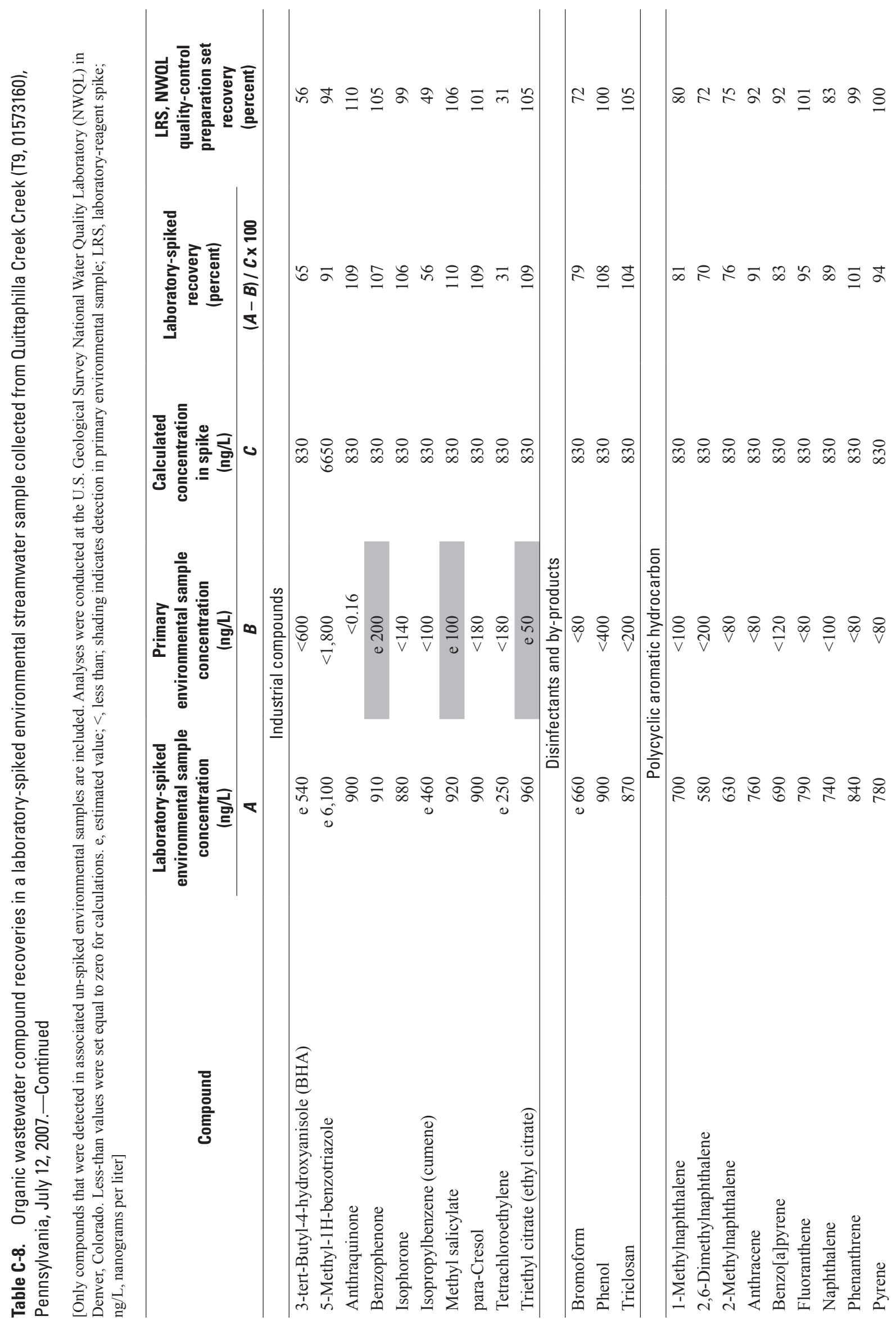




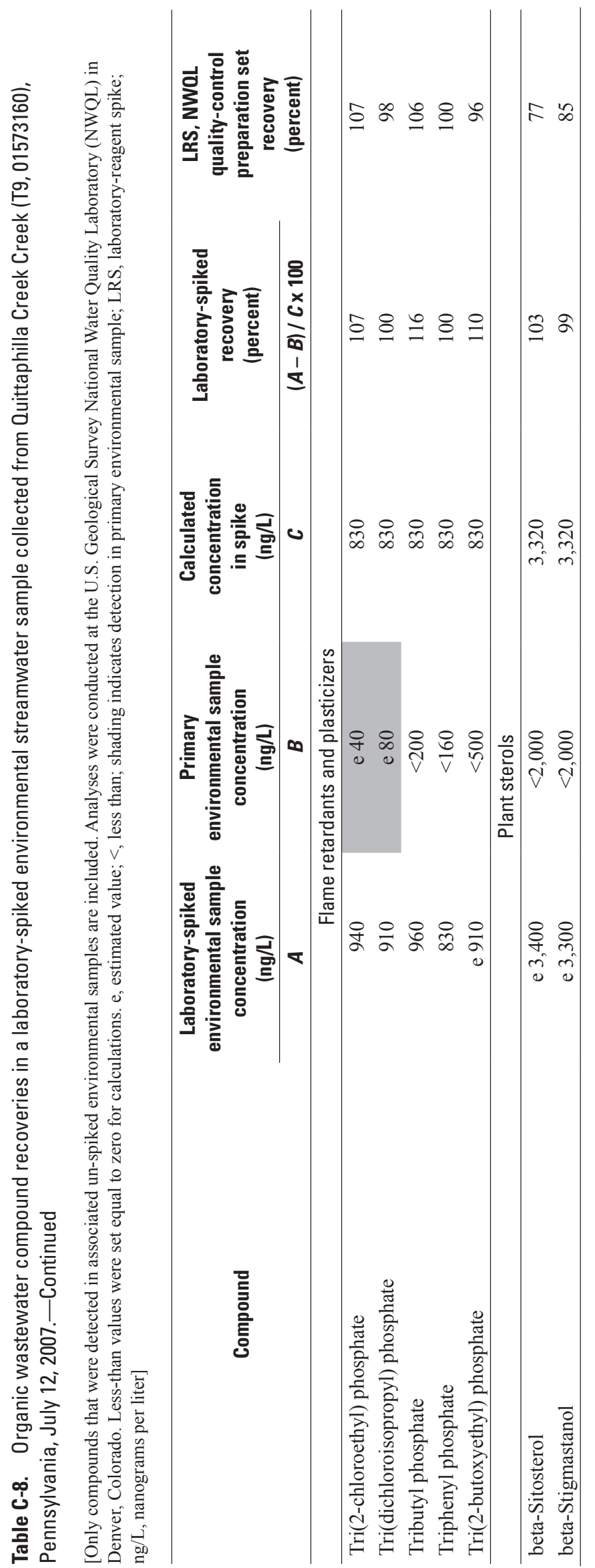




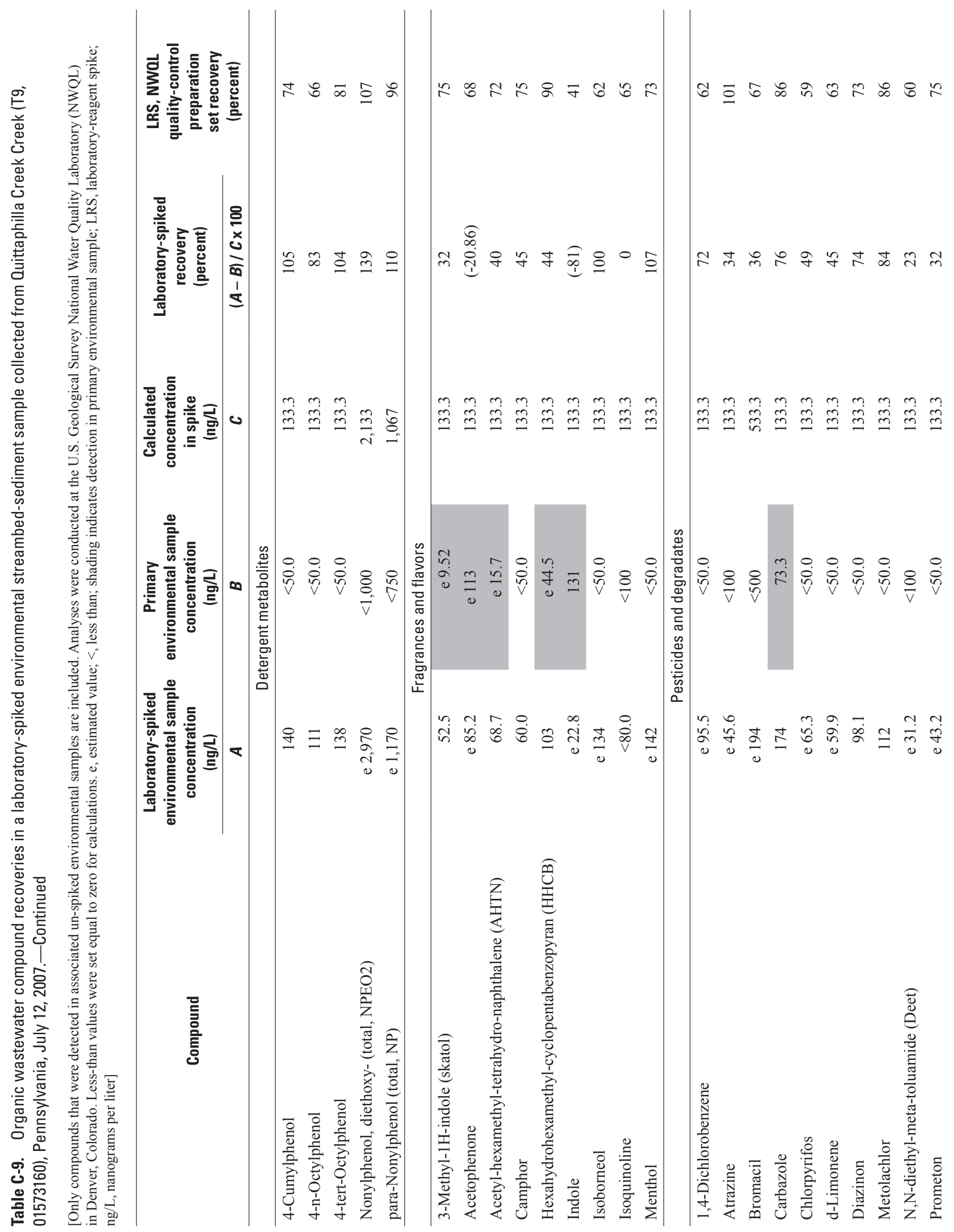




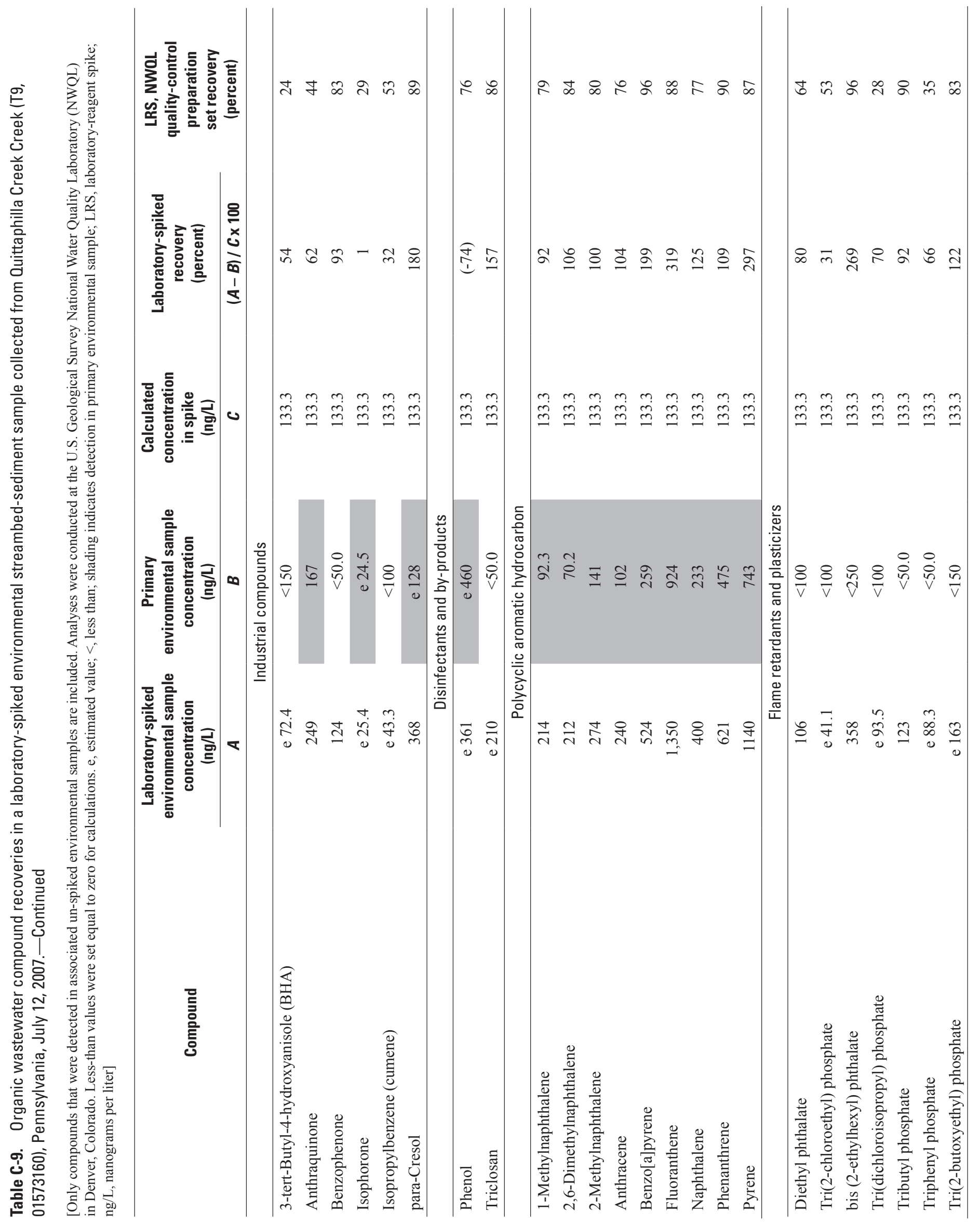




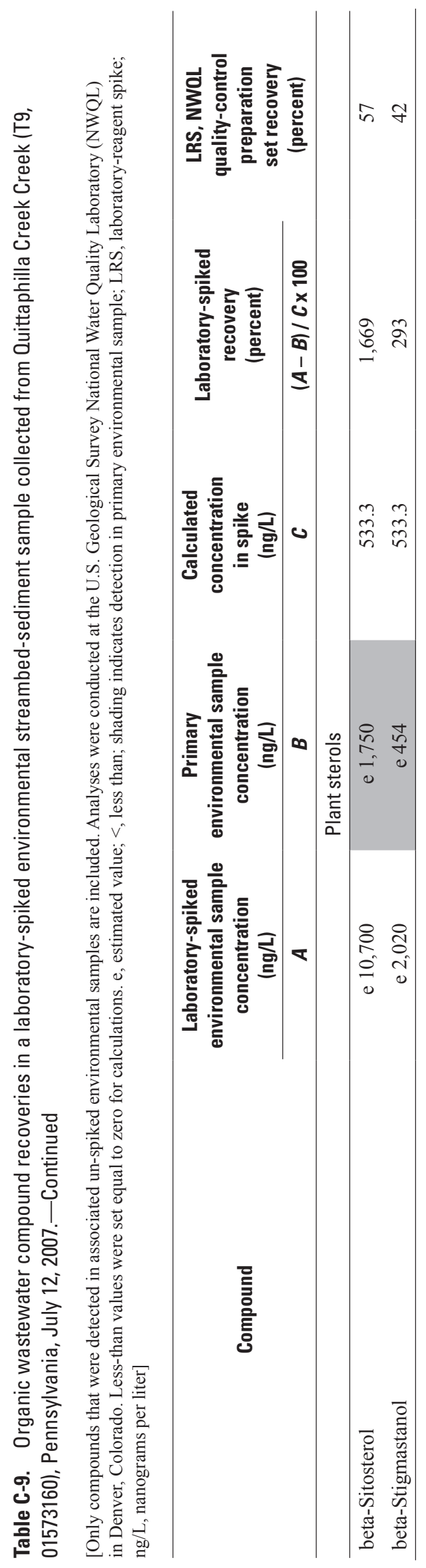



For additional information:

Director

U.S. Geological Survey

215 Limekiln Road

New Cumberland, PA 17070

http://pa.water.usgs.gov/ 


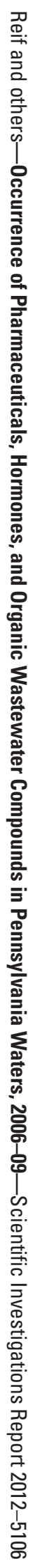

